\title{
Vítimas de Causas Externas Atendidas em Serviço de Urgência e Emergência - Subsídios ao Desenvolvimento de Sistema de Informações
}

MARCOS MESQUITA FILHO

Tese de Doutorado apresentada ao Departamento de Epidemiologia da Faculdade de Saúde Pública da Universidade de São Paulo para obtenção do título do grau de Doutor, área de concentração em Epidemiologia.

Orientadora: Professora Doutora Maria Helena Prado de Mello Jorge

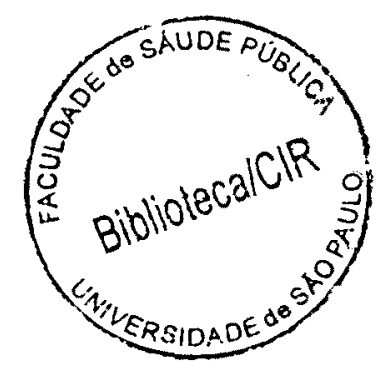




$$
44357 / 2003 \text { doe }
$$

Autorizo, exclusivamente para fins acadêmicos e cientificos, a reprodução total ou parcial desta tese, por processos fotocopiadores. Assinatura:

Data: 
Para Vânia, Tiago e Lauro

Com Amor. 


\section{Agradecimentos}

À professora doutora Maria Helena Prado de Mello Jorge pela dedicação, pelos valiosos ensinamentos que me ofereceu, pelo aprendizado que me proporcionou, pelo constante incentivo para que nos momentos dificeis eu seguisse em frente e 0 mais importante, pela grande amizade que pudemos cultivar.

Aos professores do Departamento de Epidemiologia da Faculdade de Saúde Pública da USP com quem muito aprendi nessa breve convivência.

À Tathiana Fernanda Dissoni Pereira, Jusselma Fernandes Carvalho, Alessandra Mara da Motta Paes Costa. Ana Célia de Almeida Santos Teixeira e Adelson dos Reis Matias, da equipe de Enfermagem do Pronto-Atendimento Municipal de Pouso Alegre, que tanto colabcraram na coleta de dados desta pesquisa.

Ao Flávio Cardoso Mesquita que administrou com afinco no Pronto-Atendimento a qualidade da coleta de dados.

A meu filho Lauro dos Santos Mesquita pela colaboração ao traduzir o resumo desta tese para o idioma inglês. A ele e a seu irmão Tiago dos Santos Mesquita sempre antenados e interessados em minha tese, me incentivando e me municiando com textos e materiais relacionados à pesquisa.

À Ana Cláudia Raposo Braga, professora do Departamento de Saúde Coletiva da Faculdade de Ciências Médicas "Dr. José Antônio Garcia Coutinho", da Universidade do Vale do Sapucai e Diretora de Saúde da SMS Pouso Alegre, pelo incentivo e ajuda em todos momentos de necessidade. 
À Cristiane Rocha de Moura Ferro incansável na sua ajuda diária, resolvendo meus problemas do cotidiano na Secretaria Municipal de Saúde para que eu pudesse me dedicar à tese.

À Rosângela Evaristo e ao Rodrigo Vilela Wehby, técnicos da área de Epidemiologia da Secretaria Municipal de Saúde de Pouso Alegre, pelo apoio e ajuda que me dedicaram na fase de reentrevista dos pacientes atendidos pelo PA.

A toda a equipe da Secretaria Municipal de Saúde de Pouso Alegre que tanto me ajudou direta ou indiretamente a chegar a este objetivo.

À Prefeitura Municipal de Pouso Alegre que possibilitou a realização da pesquisa em seu Pronto-Atendimento Municipal. 


\section{RESUMO}

Objetivo. Causas externas de morbidade e mortalidade são relevantes problemas de saúde pública no Brasil. Entretanto, suas características são pouco conhecidas. Muita informação é perdida por não se colher dados em serviços de urgência/emergência. São objetivos deste estudo: elaborar e avaliar ficha de notificação destes agravos nesses serviços, testar seu fluxo e apresentar e discutir as informações coletadas. Materiais e métodos. Elaborou-se ficha de notificação de causas externas que passou a ser testada. Primeiro através da avaliação por especialistas, em seguida num estudo piloto com 25 pacientes em pronto-atendimento municipal de Pouso Alegre, MG. Numa etapa seguinte foi preenchida para 380 pacientes entre fevereiro e junho de 2003, procedendo-se a coleta definitiva dos dados e estabelecendose seu fluxo. Efetuou-se reentrevista no domicílio de 73 destas vítimas além de 44 outros que foram atendidos por outros problemas. Resultados. A ficha de notificação foi facilmente preenchida num período normalmente de cinco minutos, com grande aderência pelos profissionais responsáveis. A proporção bruta de concordâncias ficha/reentrevista oscilou entre $86 \%$ e $100 \%$. Utilizando-se o indice KAPPA, indicadores como agressões e alta tiveram um desempenho de pior qualidade $(\kappa=0,37$ e 0,34$)$. Os demais mantiveram concordância entre 0,68 e 1,00. Ajustando-se este indice para viéses e pela prevalência passou-se a uma variação entre 0,73 e 1,00 para todas as variáveis. O fluxo da ficha não apresentou problemas. Os agravos mais atendidos foram outras causas externas $(72,9 \%)$, acidentes de transportes $(13,7 \%)$. A incidencia em homens foi maior que em mulheres $(2,4: 1,0)$, a maioria das vitimas era menor de 40 anos $(77,6 \%)$, o local de maior ocorrência foram residências $(40,3 \%)$, nos fins de semana (47.9\%), de 12:00 e 17:59 h $(52,1 \%)$. Ferimentos (em 72,6\% dos individuos) foram as lesões mais comuns e a localização: membros superiores $(40,0 \%)$. Conclusões. Os resultados apontam para a importância da estruturação de um sistema de informações de violências e acidentes e da viabilidade, após aperfeiçoamento, de se trabalhar a ficha de notificação. Os eventos notificados sugerem a existência de uma realidade pouco conhecida em causas externas.

Palavras-chave: Causas Externas, Lesões; Acidentes; Violências; Sistema de Informações; Serviços de Urgência e Emergência; Ficha de Notificação. 


\begin{abstract}
Objective. External causes of morbidity and mortality are relevant problems of Public Health in Brazil. However, little is known about them. A lot of information is lost due to the lack of data collecting in emergency medical care services. This present study aims at: developing and evaluating an injury surveillance record in these services, testing its flow as well as presenting and assessing the collected information. Materials and Methods. The external causes surveillance record has been developed and started to be tested, firstly through the evaluation of specialists, followed by a pilot study with 25 patients from the municipal emergency medical care units in the city of Pouso Alegre, MG. The next step was to have it filled in for 380 patients from February to June, 2003, thus proceeding to the definite data collecting process and determining its flow. Out of the 380 patients, 73 were reappraised in their domiciles and other 44 were seen for other problems. Results. The injury surveillance record was easily filled in, spending usually five minutes and with great acceptance by the answerable professional. The gross proportion of concordances record reappraisal varied from $86 \%$ to $100 \%$. When using the KAPPA index, indicators such as aggressions and discharge have had a worse quality performance $(\mathrm{K}=0.37$ and 0.34$)$. The others remained between 0.68 and 1.00. By adjusting this index to bias and by prevalence, a variation between 0.73 and 1.00 has been reached for all variables. The record flow has not presented any problems. The most common events were other external causes $(72.9 \%)$, road accidents (13.7\%). The incidence among men was higher than among women (2.4: $1.0)$, the majority was under 40 years old $(77.6 \%)$, most occurrences were at home $(40.3 \%)$, on weekends (47.9\%), from 12:00 to $17: 59$ (52.1\%). Wounds (among $72.6 \%$ of the people) were the most common lesions, in the upper limbs $(40.0 \%)$. Conclusions. The results indicate the importance of structuring a violence and accident information system as well as to the feasibility of working the injury surveillance record, after having it perfected. The notified occurrences suggest the existence of a little-known reality concerning external causes.
\end{abstract}

Keywords: External Causes, Injury; Accidents; Violence; Information Systems; Emergence Room; Injury Surveillance Record. 


\section{ÍNDICE}

1. INTRODUÇÃO 1

1.1 Considerações Gerais 1

1.2 Dimensionando o problema das causas externas 6

1.2.1 Algumas características da morbidade e mortalidade por tipos de causas externas

$\begin{array}{ll}1.3 \text { Sistemas de informação } & 18\end{array}$

1.3.1 Alguns sistemas de informação de abrangência nacional 24

1.3.2 Fontes de dados sobre causas externas utilizadas no Brasil 26

1.3.3 A qualidade das informações em causas externas 28

1.3.4 Fluxos de alguns sistemas de informação em saúde no Brasil 30

1.4 A prevenção 34

1.5 Uma abordagem epidemiológica para atuação sobre as violências e acidentes através dos serviços de saúde

1.5.1 A vigilância epidemiológica e as causas externas de mortalidade e morbidade

1.5.2 Sistemas de vigilância de lesões

1.6 Relevância do tema, limitações e finalidades do estudo

2. OBJETIVOS

3. MATERIAL E MÉTODOS

3.1 A ficha para coleta de dados

3.2 Seleção e preparo do pessoal para a coleta de dados

3.3 Definição de caso e critérios de inclusão e de exclusão

$3.4 \mathrm{O}$ estudo piloto

$3.5 \mathrm{O}$ fluxo das informações 
3.8 Testando a ficha de notificação 63

3.9 O banco de dados $\quad 64$

3.10 Medidas utilizadas $\quad 64$

3.11 Investigação de associações $\quad 65$

4. RESULTADOS E DISCUSSÃO 66

$\begin{array}{ll}\text { 4.1 A ficha de notificação de causas externas } & 69\end{array}$

4.1.1 A confiabilidade da ficha de notificação 69

$\begin{array}{ll}\text { 4.1.2 O fluxo de informações } & 78\end{array}$

4.2 Vítimas e circunstâncias dos agravos: distribuição, freqüência e $\begin{array}{ll}\text { possiveis determinantes } & 80\end{array}$

$\begin{array}{ll}\text { 4.2.1 Tipos de acidentes e de violências } & 80\end{array}$

4.2.2 As causas externas de morbidade e mortalidade notificadas 82

$\begin{array}{lr}\text { 4.2.3 Caracteristicas das vitimas } & 83\end{array}$

4.2.4 Circunstâncias das ocorrências $\quad 86$

4.2.5 Detalhamento das causas externas de morbidade e mortalidade notificadas

4.2.6 Lesões, envenenamentos e algumas outras conseqüências de causas externas notificadas e a localização das lesões por segmento corpóreo

4.2.7 Procedimentos efetuados pelo serviço de saúde e destino dos pacientes

$\begin{array}{ll}\text { 6. CONSIDERAÇÕES FINAIS } & 117\end{array}$

$\begin{array}{ll}\text { 7. REFERÊNCIAS BIBLIOGRÁFICAS } & 119\end{array}$

ANEXOS

Anexo 1 - Modelo da ficha de notificação de causas externas em serviços de urgência emergência. 
Anexo 2 - Estudo piloto.

Anexo 3 - Dados sobre o municipio de Pouso Alegre, MG.

Anexo 4 - Manual de Instruções para preenchimento da ficha de notificação.

\section{LISTA DE TABELAS}

Tabelas 1 - Concordância entre ficha de notificações e reentrevista de pacientes atendidos devidos a causas externas no serviço municipal de pronto-atendimento em Pouso Alegre, MG, por tópico.

Tabela 1.1 - Local afetado: Cabeça 71

Tabela 1.2 - Local afetado: Membros superiores 71

Tabela 3.3 - Local afetado: Membros inferiores 71

Tabela 1.4 - Tipo de lesão: Ferimento 71

Tabela 1.5 - Tipo de lesão: Traumatismo superficial 71

Tabela 1.6- Tipo de Causa externa: Outras causas externas de traumatismos acidentais $\quad 71$

Tabela 1.7 - Tipo de Causa externa: Acidentes de transporte 72

Tabela 1.8 - Tipo de causa externa: Agressões 72

Tabela 1.9 - Local de ocorrência: Residência 72

Tabela 1.10 - Local de ocorrência: Rua 72

Tabela 1.11 - Local de ocorrência: Local de trabalho 72

Tabela 1.12 - Destino: Alta 72

Tabela 2- Proporções (\%) brutas de concordância e seus intervalos de confiança (IC, 95\%) para respostas de questões selecionadas da ficha de notificação de causas externas e reentrevista em pacientes atendidos por serviço de atenção às urgências no município de Pouso Alegre, MG, fevereiro a junho de 2003 ( $n=73$ ).

Tabela 3 - Concordância entre medidas efetuadas pela ficha de notificação para causas externas e reentrevista em serviço municipal de atendimento a urgências em Pouso Alegre, MG, entre fevereiro e junho de 2003, através do índice KAPPA bruto e seu intervalo de confiança (IC, $95 \%$ ), e o ajustado.

Tabela 4 - Vítimas por tipo de causa externa (N. ${ }^{\circ}$ e \%) atendidas em serviço de atenção às urgências no município de Pouso Alegre, MG, fevereiro a junho de 2003 
Tabela 5 - Vitimas de causas externas de morbidade e mortalidade atendidas em serviço de atenção às urgências no município de Pouso Alegre, MG, fevereiro a junho de 2003 segundo faixa etária e sexo (N. ${ }^{\circ}$ e \%)

Tabela 6 - Taxa de vítimas por região de residência (por cem mil habitantes) em vítimas de causas externas de morbidade e mortalidade atendidas em serviço de atenção às urgências no município de Pouso Alegre, MG, fevereiro a junho de 2003 segundo região de residência $\left(N .^{\circ}\right.$ e \%).

Tabela 7 - Vítimas de causas externas de morbidade e mortalidade atendidas em serviço de atenção às urgências no município de Pouso Alegre, $M G$, fevereiro a junho de 2003 segundo dia da semana (n. ${ }^{\circ}$ e \%).

Tabela 8 - Vítimas de causas externas de morbidade e mortalidade atendidas em serviço de atenção às urgências no município de Pouso Alegre, $M G$, fevereiro a junho de 2003 segundo causa e dia da semana (n. ${ }^{\circ}$.

Tabela 9 - Vítimas de causas externas de morbidade e mortalidade atendidas em serviço de atenção às urgências no município de Pouso Alegre, $M G$, fevereiro a junho de 2003, segundo horário de ocorrência (n. $\left.{ }^{\circ} \mathrm{e} \%\right)$.

Tabela 10 - Vitimas de causas externas de morbidade e mortalidade atendidas em serviço de atenção às urgências no município de Pouso Alegre, MG, fevereiro a junho de 2003, segundo causa e horário de ocorrência (n. ${ }^{\circ}$ ).

Tabela 11 - Causas e locais de ocorrência de agravos à saúde provocados por causas externas em individuos atendidos em serviço de atenção às urgências no município de Pouso Alegre, MG, fevereiro a junho de 2003

Tabela 12 - Vítimas de outras causas externas de traumatismos acidentais atendidas em serviço de atenção às urgências no município de Pouso Alegre, MG, fevereiro a junho de 2003, segundo causa e faixa etária $\left(\mathrm{N}^{\circ}{ }^{\circ}\right)$

Tabela 13 - Tipos de acidentes automobilisticos e faixa etária de pacientes atendidos por estes agravos em serviço de urgências em Pouso Alegre, de fevereiro a junho de 2003.

Tabela 14 - Tipos de agressões e faixa etária de pacientes atendidos por estes agravos em serviço de urgências em Pouso Alegre, de fevereiro a junho de 2003102 
Tabela 15 - Número e proporção de lesões, envenenamentos e algumas outras consequuências de causas externas em pessoas que foram atendidas em serviço de atenção às urgências no município de Pouso Alegre, MG, fevereiro a junho de 2003 (Número total e percentagem).

Tabela 16 - Lesões segundo tipo de causa externa de morbidade e mortalidade em pacientes atendidos em serviço de atenção às urgências no município de Pouso Alegre, MG, fevereiro a junho de 2003 (N. ${ }^{\circ}$ e \%)

Tabela 17 - Tipos e localização de lesões em pacientes atendidos em serviço de atenção às urgèncias no município de Pouso Alegre, $M G$, fevereiro a junho de 2003.

109

Tabela 18 - Procedimentos efetuados em vítimas causas externas de morbidade e mortalidade atendidas em serviço de atenção às urgências no município de Pouso Alegre, MG, fevereiro a junho de 2003

Tabela 19 - Procedimentos efetuados em vítimas causas externas de morbidade e mortalidade atendidas em serviço de atenção às urgências no municipio de Pouso Alegre, MG, fevereiro a junho de 2003, segundo causa externa.

Tabela 20 - Tempo de permanência no serviço de atendimento a urgências pelas vítimas de agravos ocasionados por causas externas de morbidade e mortalidade em Pouso Alegre, MG, $2002\left(\right.$ N. ${ }^{\circ}$ e \%)

\section{LISTA DE FIGURAS}

Figura 1 - Cobertura por parte das diversas fontes de informação existentes das ocorrèncias em causas externas

Figura 2 - Fluxo de informações para óbitos no SIM

Figura 3 - Fluxo de Informações do SINAN

Figura 4 - Fluxo básico de Autorização de Internação Hospitalar (AIH)

Figura 5: Fluxo das informações de notificação de causas externas em serviços de urgência e emergência

Figura 6 - Vitimas de causas externas de morbidade e mortalidade atendidas em serviço de atenção às urgências no município de Pouso Alegre, MG, fevereiro a junho de 2003 segundo região de residência (\%) 
Figura 7 - Freqüência das vítimas de outras causas externas de traumatismi: segundo tipo de causa externa, que foram atendidas em serviço de atenção às urgências no município de Pouso Alegre, MG, fevereiro a junho de 2003 (\%). 96 Figura 8 - Freqüência de vítimas de acidentes de transporte atendidas em serviço de atenção às urgências no municipio de Pouso Alegre, MG, fevereiro a junho de 2003 $(\%)$

Fignra 9 - Tipos de acidentes de transporte em que as vítimas foram atendidas em serviço de atenção às urgências no município de Pouso Alegre, MG, fevereiro a junho de $2003(\%)$

Figura 10 - Proporção de lesões apresentadas por faixa etária em pacientes atendidos em serviço de atenção às urgências no município de Pouso Alegre, MG, fevereiro a junho de 2003

Figura 11 - Topografia de lesões cujas vitimas foram atendidas em serviço de atenção às urgências no município de Pouso Alegre, MG, fevereiro a junho de 2003

Figura 12 - Proporção de lesões apresentadas por segmento corpóreo atingido segundo algumas causas externas de morbidade e mortalidade em pacientes atendidos em serviço de atenção às urgências no município de Pouso Alegre, MG, fevereiro a junho de 2003 


\section{1- INTRODUÇĀO}

\subsection{Considerações Gerais}

Agravos resultantes das denominadas causas externas de morbidade e de mortalidade têm sido de fundamental importância na agenda do setor saúde. Os problemas provocados por acidentes e violências, por ocasionarem conseqüências orgânicas, psicológicas, sociais e econômicas, são responsáveis por significativa parcela da mortalidade, morbidade e sofrimento humanos. As causas externas são considerados graves problemas de saúde pública pela extensão e gravidade dos danos que provocam, por causarem um grande número de vítimas, fatais ou não, seqüelas e incapacidades, por acometerem preferencialmente jovens em idade produtiva, pela factibilidade de sua prevenção, por sobrecarregarem os serviços de saúde, por apresentarem altissimos custos e por terem uma alta incidência. Tratam-se, outrossim, de um desafio para as políticas e serviços de saúde e, ainda, para os diversos setores que apresentam interfaces nesta área. Vários estudos têm sido efetuados com o intuito de conhecer o problema, principalmente na área de mortalidade, tanto no Brasil como em outros paises. Entretanto, muito pouco tem sido feito para a prevenção e para a prestação de serviços de atendimento de boa qualidade às suas vitimas. Na "Política Nacional de Redução de Morbimortalidade por Acidentes e Violências" (BRASIL, 2001) afirma-se que "os acidentes e violências no Brasil configuram um problema de saúde pública de grande magnitude e transcendência, que tem provocado forte impacto na morbidade e mortalidade da população".

Para a contextualização das causas externas de lesão é necessário que sejam estudadas lembrando-se que, em grande parte, elas integram o âmbito das violências na sociedade. Este fato é importante para não se correr o risco de se minimizar sua importância nem de não se compreender toda sua abrangência, considerando-as erroneamente como frutos do imprevisível, do inevitável, escamoteando-se a omissão ou a intencionalidade, às vezes encobertas nestas situações. A palavra "acidente", que em inúmeras ocasiões, é usada para nomear esse tipo de evento (grupamentos V01 a X59, CID-10, 1995), pode levar a uma falsa atenuação de inúmeras de suas caracteristicas perversas, representadas pelo descaso e descuido com a vida humana. 
Tende-se a diluir a gravidade de diversas de suas manifestações através de uma abordagem na linha da "não-intencionalidade" do evento. O enfoque de muitas vezes tomá-las como de ocorrência fortuita, acidental, como fruto da fatalidade, ou de natureza involuntária, serve para minimizar a sua importância. DELATORRE (1999) utilizando-se da análise de Arendt, separa o exercício pseudo-científico da ocorrência real dos eventos, que não são tão inesperados assim, pois existem evidências da possibilidade de sua ocorrência, "que advirão se os homens não agirem". A autora continua chamando a atenção que denominar de inesperados, imprevistos e imprevisíveis eventos tidos como casuais prenuncia um "velho truque", que "adormece nosso senso comum, que nada mais é do que nosso órgão espiritual para perceber, entender e lidar com a realidade e com os fatos". Esse "adormecimento do senso comum" também reforça o escamoteamento da visualização do caráter violento implicito e da intrincada rede de fatores que os determinam. Ernst Jünger, que estetizou a batalha de material bélico da $\mathrm{I}^{\mathrm{a}}$. Guerra Mundial sendo por isto considerado "o artista da grande matança", admira-se com o fato de que as pessoas aceitam. "com uma certa naturalidade", a quantidade enorme de vitimas. Ele desconfia que elas parecem "necessárias" porque "são adequadas a nosso espaço, isto é, ao espaço do trabalho" (KURZ, 1997).

A tendência geral do enfoque da violência situa na esfera individual a responsabilidade por ela: por desejo, por descuido, por estar "fora de si" ou por não medir as conseqüências. Tal fato induz à ocultação de todo um processo que é resultado de interações dolorosas e, às vezes, prolongadas, de causas cujos efeitos repercutem não só no âmbito restrito do indivíduo, família e grupo social, mas também de forma mais abrangente no âmbito econômico, social e cultural da sociedade (LÓPEZ e cols, 1996). MINAYO (1994) coloca a violência como "um dos eternos problemas da teoria social e da prática política e relacional da humanidade. Não se conhece nenhuma sociedade onde ela não tenha estado presente". A violência é ai entendida não como algo biológico, inerente à natureza humana, mas "trata-se de um complexo e dinâmico fenômeno biopsicossocial; seu espaço de criação é a vida em sociedade (...) e na configuração da violência se cruzam problemas da política, da economia, da moral, do direito, da psicologia, das relações humanas e institucionais, e do plano individual". Nesta visão, a questão da violência surge como 
interdisciplinar, multifacetada, não fazendo parte de apenas um campo específico do conhecimento, mas que deve, para sua compreensão, ser analisada em rede, onde a violência estrutural serve também de marco à violência do comportamento (MINAYO, 1990).

Violência, segundo o Grupo de Trabalho Sobre as Conseqüências Psicossociais da Violência, que se reuniu em Haia em 1981 OMS/ OPAS, 1993a), "é a imposição inter-humana de um grau de dor e sofrimento evitáveis". Trata-se de uma definição extremamente ampla que não especifica relações entre o problema da violência com a intencionalidade do ato, com a falta de consentimento da vitima, com as dimensões temporais das conseqüências dos agravos à saúde e nem com as repercussões sociais e coletivas que são geradas por ela. A dimensão "inter-humana" que é colocada nessa definição, ao mesmo tempo em que inclui todos os tipos de violência entre seres humanos, exclui aqueles em que o homem ou não tem nenhum papel, ou tem pequena influencia, como em algumas das catástrofes da natureza. As suas diferentes manifestações em nivel individual e coletivo, a diversidade de fatores que a originam e a gama de consequiências sociais que gera fazem dela um fenômeno complexo: "os atos de violência se referem a condutas humanas de conseqüências nos planos somático, psicossocial e ético (...) ainda que não necessariamente correspondam a uma causalidade de natureza simples" (OMS/OPAS, 1993a). Já na "Politica Nacional de Redução de Morbimortalidade por Acidentes e Violências" (BRASIL, 2001) coloca-se que "os acidentes e violências resultam de ações ou omissões humanas e de condicionantes técnicos e sociais". Assume como violência "o evento representado por ações realizadas por indivíduos, grupos, classes, nações, que ocasionam danos físicos, emocionais, morais e/ou espirituais a si próprio ou a outros". Apresenta profundos enraizamentos nas estruturas sociais, econômicas e politicas, bem como nas consciências individuais, numa reação dinâmica entre os envolvidos. Ela pode se expressar de muitas formas: agressão fisica, abuso sexual, violência psicológica e violência institucional. Atinge de forma diversa os diversos grupos sociais.

Nos paises que vêm experimentando os processos de desenvolvimento urbano, tecnológico e industrial, destaca-se a importância da vida em comunidade e das experiências da realidade cotidiana como fatores que se associam às principais 
causas de morte e de doença. Isso, aliado à mudança de estilos e qualidade de vida e ao controle das doenças infecciosas como causas de morte, tem contribuído para transformações que levaram ao aumento da esperança de vida, e à modificação dos padrões de morbimortalidade, com impactos diferentes nas condições de saúde dos diversos países, de acordo com seu grau de desenvolvimento (MÉDICI, 1992). Estas mudanças foram acompanhadas pelo aumento dos óbitos e agravos por doenças crônicas não-transmissiveis e por causas externas e segundo OMRAN (1971) e LAURENTI (1990) configuram os fenômenos que caracterizam as transições demográfica e epidemiológica. Enquanto os países desenvolvidos, vivenciaram um processo de modificação nos padrões de morbimortalidade, atravessando três fases epidemiológicas estabelecidas pela teoria de OMRAM (1971), quais sejam: a "Era da Fome, das Pestilências", a "Era do Declínio das Pandemias" e a "Era das Doenças Degenerativas e das causadas pelo Homem" os menos desenvolvidos vivem essas situações de forma concomitante, apresentando as várias fases num mesmo periodo, de forma simultânea. VERMELHO e MONTEIRO (2002) informam ainda dois outros estágios: o quarto que corresponde ao "período do declínio da mortalidade por doenças cardiovasculares, envelhecimento populacional, modificações no estilo de vida, doenças emergentes e ressurgimento de doenças" e o quinto: "periodo de longevidade paradoxal, emergência de doenças enigmáticas e capacitação tecnológica para a sobrevivência do inapto". Esta teoria tem recebido ao longo do tempo críticas por autores como LAURELL (1983) segundo a qual, a afirmativa de que patologias tais como as doenças cardiovasculares e os tumores emergem simplesmente como novos ocupantes de espaços antes preenchidos pelas doenças infecciosas, é baseada em uma concepção linear e desenvolvimentista da doença na sociedade, que vê a história das doenças como simples resultados das forças produtivas, do grau de dominio do homem sobre a natureza. A autora conclui que OMRAM elimina o caráter histórico e social do processo, não pressupondo que cada sociedade possa criar seu próprio perfil patológico.Tal fato é comprovado, segundo a auiora, quando se observa que nem todos os paises que conseguem reduzir significativamente a ocorrência de doenças infecciosas passam a observar taxas semelhantes de mortalidade.

O Brasil, apesar de ter mostrado nos últimos vinte anos o crescimento da 
esperança de vida ao nascer, a queda das taxas de mortalidade infantil e da taxa geral de fecundidade, vem apresentando um perfil epidemiológico crítico, caracterizado pela presença concomitante de doenças de países desenvolvidos e das dos em desenvolvimento, agravado pelo recrudescimento de doenças consideradas erradicadas ou sob controle, tais como a dengue e a febre amarela.

A este cenário desfavorável soma-se a importância das causas externas, principalmente acidentes de trânsito e homicídios enquanto geradoras de óbitos, lesões e incapacidades em variados graus. Para se ter uma idéia, entre 1991 e 1998, a taxa de mortalidade por homicídios no Brasil cresceu de 20,9 para 25,9 óbitos por cem mil habitantes. Na região Sudeste a situação é mais grave pois estas taxas aumentaram de 27,0 para 35,9 . Se forem consideradas todas as causas externas os números do país passam respectivamente a ser de 69,5 e 72,7 óbitos por cem mil habitantes. As causas externas foram também responsáveis por 5,8 por cento das internações hospitalares no país em 1998 , chegando na região Sudeste a 6,8 por cento (RIPSA, 2002).

As violências não têm, na maioria das vezes, origem no setor saúde. Entretanto, independentemente das caracteristicas multifacetadas da gênese $\mathrm{e}$ ocorrência das violências, suas conseqüências têm repercussão direta sobre o setor saúde. Seus resultados ai se manifestam principalmente pela demanda de suas vítimas aos serviços destinados às urgências e às emergências, entre outros. De acordo com a OMS/OPAS (1993a) "o setor saúde constitui a encruzilhada para onde confluem todos os corolários da violência, pela pressão que exercem suas vítimas sobre os serviços de urgência, de atenção especializada, de reabilitação física, psicológica e de assistência social".

O relatório da $111^{\mathrm{a}}$ reunião conjunta da OPAS e da OMS, realizada em Washington em junho/julho de 1993, afirma que "a violência, pelo número de vítimas e magnitude de seqüelas orgânicas e emocionais que produz, adquiriu um caráter endêmico e se converteu num problema de saúde pública em vários paises" e ainda que "a violência afeta todos os estratos da sociedade". A resolução XIX, apresentada na XXXVII reunião do conselho diretivo da OMS/OPAS, "Violencia y Salud" (OMS/OPAS, 1993b) salienta que "a prevenção da violência é possível por 
ser expressão de comportamentos humanos, atitudes e estilos de vida modificáveis mediante ações de promoção da saúde". É verdade que parte das medidas preventivas não são atribuição da área da saúde, e sim de outros setores sociais. A citada resolução XIX contudo afirma que "o setor saúde deveria desempenhar um papel fundamental junto com outros setores na busca de soluções e aplicação de medidas preventivas e de controle de todas as formas de violência" (OMS/OPAS, 1993b). Entretanto, como expõe o relatório final da $111^{\mathrm{a}}$ reunião da OMS/OPAS (1993a), "a resposta do setor saúde tem sido insuficiente. Concentrou-se na atenção imediata às lesões. Mesmo nesse têm sido escassas e, em geral, limitadas a experiências isoladas".

Apesar da baixa capacidade em dar respostas adequadas na promoção, prevenção e recuperação em causas externas, os custos para os sistemas de saúde são altíssimos e seriam provavelmente ainda maiores se as ações exercidas fossem de boa qualidade. Entretanto, é importante que "mesmo que os sistemas de saúde não estejam adequadamente preparados para atender o quadro de morbimortalidade trazido pela violência em seus distintos matizes, não se deve 'banalizar o fenômeno' ou enquadrar a violência dentro de parâmetros de normalidade". No Brasil, os serviços de saúde estão, geralmente, pouco alertas e motivados para atuar nesta área. A politica pública existente (BRASIL, 2001), com propostas para atuação sobre estes problemas, ainda não se encontra efetivamente implantada, bem como, ainda não foi desenvolvido instrumental adequado para seu equacionamento. Entretanto, por ser um problema das condições politicas, sociais e econōmicas, a 'epidemiologia da violência' encontra fora dos serviços de saúde seu principal 'locus' de causalidade e resolutividade (...); medidas de âmbito político, normativo-institucional, social e econômico poderão prevenir e "resolver boa parte dos problemas de saúde causados pela violência" (MÉDICI, 1992).

\subsection{Dimensionando o Problema das Causas Externas}

Em 1998 estimou-se que 5,8 milhões de pessoas morreram em todo o mundo devido a lesões originárias das causas externas, o que correspondeu a uma taxa de 97,9 óbitos 'por cem mil habitantes. Destes, 3,8 milhões eram homens (128,0 por 
cem mil habitantes) e 1,9 milhões (66,7 por cem mil habitantes) eram mulheres. As causas externas que causam o maior número de mortes em todo o mundo são os acidentes de transporte e as lesões auto-infligidas (KRUG, 1999)

As estatísticas de mortalidade no Brasil mostram que até 1940 havia um nítido predominio das doenças infecciosas e parasitárias como causa de morte (43,5\% do total de óbitos). As doenças do aparelho circulatório correspondiam a $14,5 \%$ e as neoplasias malignas a $3,9 \%$ dos óbitos com causa definida. Trinta anos depois, em 1970, as doenças do aparelho circulatório já surgiam como a primeira causa de mortalidade $(24,8 \%)$, as doenças infecciosas e parasitárias como a segunda $(15,7 \%)$ e as neoplasias malignas como a terceira (9,7\%). Já em 1986 as doenças do aparelho circulatório já eram responsáveis por 33,5\% dos óbitos, vindo em segundo lugar as causas externas $(14,8 \%)$ e em terceiro, as neoplasias malignas $(11,9 \%)$. MELLO JORGE \& GOTLIEB (2.000) informam que as causas externas, com uma taxa de 76,0 óbitos por cem mil habitantes no ano de 1996, causaram 13,1\% do total geral de mortes. Quando calculada em relação ao total das ocasionadas por causas definidas, essa proporção ultrapassou os 15,0\%. É importante salientar que no periodo entre 1977 e 1996 houve um aumento de mais de 50,0\% naquele coeficiente de mortalidade. GAWRYSZEWSKI \& MELLO JORGE (2000) estudando a mortalidade violenta do município de São Paulo durante quarenta anos (entre $1960 \mathrm{e}$ 1999), constataram, neste periodo, um aumento de 90,0\% nos coeficientes de mortalidade por causas externas, sendo que até 1975 eram os acidentes de trânsito que mais contribuiam para esse crescimento e os homicídios na década de 80. Estes cresceram $906,8 \%$ no periodo, especialmente para as faixas mais jovens (10 a 24 anos).

No Brasil, as causas externas, além de sua importância nas taxas de mortalidade da população em geral, se apresentam nos estratos mais jovens da população (dos cinco até os 39 anos de idade) como as maiores causadoras de óbitos. Em 1991 foram responsáveis por, praticamente, 65,0\% das mortes na faixa dos 15 aos 19 anos e de 59,0\% na de 20 a 29 (MELLO JORGE, GAWRYSZEWSKI \& LATORRE, 1997). Em 1998 a proporção dos óbitos em adolescentes entre 15 e 19 anos sobe para $68 \%$ e se forem levados em conta apenas os óbitos masculinos desta faixa etária estas proporções elevam-se a 76,7\%. São Paulo atingiu valores de $84,0 \%$ 
e o Rio de Janeiro $81,5 \%$ para os homens desta idade, no mesmo ano e o total da região Sudeste foi maior que $80,0 \%$ (SIMÕES, 2002). MELLO JORGE (1988) informa que quase metade das mortes ocorridas entre os cinco e 14 anos de idade no Brasil são ocasionadas por causas externas. Estas ocorrências redundam num aumento em até $30,0 \%$ do número total de anos potenciais de vida perdidos (APVP) no país. No Brasil, no triênio 1993/1995 foram perdidos 11.281.217,50 anos potenciais de vida por causas externas (MELLO JORGE \& GOTLIEB, 2.000), valor correspondente a 22,1\% de todos os APVP desse período. Em 1992 foram perdidos, em média, 11,2 anos potenciais de vida em individuos do sexo masculino no Brasil. Destes, 2,7 se deveram às causas citadas. Em 1998 foram perdidos 10,6 anos sendo que a contribuição das causas externas é de 2,7 (se se considerar duas casas decimais, houve o aumento de 2,68 para 2,71). Comparando-se com as demais causas de óbito, essa é a que produz a maior perda média de anos de vida. "Esse indicador vem tendo um impacto bastante negativo na esperança de vida masculina brasileira que não tem aumentado de forma satisfatória, em função do impacto das causas externas" (SIMÕES, 2002).

Existe uma proporção de óbitos por causas externas significativamente maior entre individuos do sexo masculino que entre os do feminino. A probabilidade de um homem morrer devido aos acidentes e violências chega a ser mais de quatro vezes maior do que a da mulher (SIMÕES, 2002). No triênio 1993/1995 corresponderam a $17,2 \%$ do total de mortes de homens, contra 5,3\% das de mulheres (MELLO JORGE \& GOTLIEB, 2.000). Estudando-se a razão entre as taxas é possível demonstrar uma acentuada sobremortalidade masculina da ordem de 4,5:1,0. Todas as regiōes do Brasil, com exceção da região Sul, apresentaram entre 1992 e 1995 um crescimento do número de anos perdidos por causas externas, para a população masculina. Em contrapartida, houve o decréscimo deste indicador entre as mulheres de todas as regiões do Brasil, excetuando-se também a região Sul com uma pequena flutuação $(0,47$ para 0,48$)$.

Óbitos ocasionados pelos homicídios e acidentes de trânsito são fenômenos principalmente urbanos apesar de também serem importantes em regiões rurais. MELLO JORGE, GAWRYSZEWSKI \& LATORRE (1997) mostraram que em $88,5 \%$ das capitais brasileiras, no período entre 1977 e 1994 , o número de mortes por 
homicídios tem apresentado tendência crescente. Nos outros municípios $(11,5 \%$ das capitais), apesar deste valor não ter aumentado, também não se verificou tendência ao decréscimo. Quanto aos acidentes de trânsito, houve aumento de suas taxas de mortalidade em $50,0 \%$ destas capitais no período, diminuindo as de $23,1 \%$, sendo que em 19,2\% elas se encontravam estacionárias. Não se obteve informações em $7,7 \%$ dos municipios estudados. No periodo entre 1991 e 1998 (RIPSA, 2001) as principais causas externas de óbito foram os homicidios (taxa de 20,9 óbitos por cem mil habitantes em 1991 e de 25,9 em 1998). Em seguida as mais importantes causas foram respectivamente acidentes de transporte e suicídios.

Violências e acidentes são eventos geradores de substantivo número internações. Em 1996, 6,0\% das hospitalizações ocorridas nos serviços ligados ao Sistema Único de Saúde (SUS) foram por lesões e envenenamentos, ou seja, por causas externas. $O$ tempo de permanência em regime de internação foi, em média, de cinco dias. As lesões que provocaram o maior número de internações foram as fraturas (37,5\% dos casos) segundo WALDMAN \& MELLO JORGE, (1999); LEBRÃO, MELLO JORGE \& LAURENTI (1997). Esta é, entretanto, apenas a pequena ponta de um iceberg pois as características desta morbidade são ainda pouco conhecidas. O estudo de MESQUITA FILHO (1998), efetuado a partir de indivíduos que sofreram algum tipo de lesão por acidentes de transporte e que foram atendidos em serviço de urgência e emergência ligado ao Sistema Único de Saúde (SUS) em Pouso Alegre, MG e que não foram a óbito, encontrou uma ocorrência de agravos em 592,4 pessoas por cem mil habitantes. Mostrou também que entre essas vítimas nãofatais de acidentes de trânsito houve uma proporção de $57,6 \%$ de incapacidades autoreferidas. Mais da metade deste grupo sofreu traumatismos, ou na cabeça, ou nos membros inferiores. Dos acidentados entrevistados, 19,1\% admitiu o consumo de bebidas alcoólicas e $77 \%$ negou o uso de qualquer equipamento de segurança tais como capacetes ou cintos de segurança no momento do acidente. FRIEDMAN e cols. (1991), num estudo dos politraumatizados que deram entrada no pronto-socorro de Porto Alegre e que foram internados em UTI, detectaram 35 em 56 pacientes apresentando alcoolemia acima dos padrões toleráveis. DESLANDES \& SILVA (2000) estudando dois hospitais de referência para causas externas do Rio de Janeiro, nos meses de maio (hospital 1) e no de junho (hospital 2) do ano de 1996, 
constataram que foram atendidos no hospital 1, 2.736 vitimas de causas externas (320 acidentes de trânsito) e no hospital 2, 2.415 (290 acidentes de trânsito).

$\mathrm{Na}$ América Latina e Caribe, morrem por homicídio intencional de $110 \mathrm{mil} \mathrm{a}$ 120 mil pessoas a cada ano. Por acidentes de trânsito morre uma quantidade similar. Entre 80 e $95 \%$ dos casos se tratam de homens. O homicídio é a primeira causa de mortalidade em vários paises criando e favorecendo, em nível familiar, o ciclo de violência entre seus membros, sendo que, sua reprodução causa a erosão do tecido social e dificulta a resolução de problemas ligados ao desenvolvimento, cujas iniqüidades formam, por sua vez, parte dos múltiplos fatores causais e de risco que contribuem para a geração de eventos violentos. É um desafio para a saúde pública, por ser uma enfermidade social conhecida, fazer com que se dedique esforços para evitar sua ocorrència e quando o mesmo se apresentar, atender e reabilitar suas vítimas (CONCHA-EASTMAN \& VILLAVECES, 2001).

Trabalhos norte-americanos informam que traumas e lesões causaram 2,8 milhões de internações em 1988 (9,0\% do total destes procedimentos). Este número só foi ultrapassado pelos das doenças dos sistemas circulatório, digestivo e respiratório. Resultaram também em 114 milhões de consultas médicas naquele país, no mesmo ano, o que foi superado apenas pelos problemas do aparelho respiratório. Mais de $25 \%$ de todos os atendimentos dos serviços de emergência foram para estes agravos à saúde (BAKER e cols., 1992).

Um recente estudo a partir da base de dados NEISS-AIP (National Electronic Injury Surveillance Syatem: All Injury Program), pertencente ao Consumer Product Safety Comission (CPSC) nos Estados Unidos da América (EUA) estimou que no ano de 2.000 , lesões não-fatais provocadas por causas externas tratadas em serviços de emergência ocorreram em cerca de 31 milhões de pessoas (MMWR, 2001). Estes números permitem afirmar que por volta de $10 \%$ da população dos EUA recebeu tratamento, em serviços de pronto-socorro, para algum tipo de agravo provocado por causas externas. A taxa de incidência destes agravos foi de 11.188 casos por cem mil habitantes, sendo $40 \%$ mais alta entre os homens que entre as mulheres, estando no sexo masculino e na faixa etária de 15 a 19 anos as mais altas taxas (20.528 por cem mil habitantes). $93,6 \%$ dos casos foram classificados como não-intencionais enquanto $6,4 \%$ (por volta de dois milhões de pessoas) foram relacionados com 
violências. Entre as não-intencionais, a causa mais comum foram as quedas. Calculou-se que 3.299.000 individuos dessa população eram ocupantes de veículos a motor, sendo que $95,2 \%$ eram relacionadas a eventos ocorridos no trânsito. Houve o comparecimento de 389.000 pessoas, a serviços de emergência, para tratamento de mordidas de cães.

Em estudo realizado pelo National Center for Injury Prevention and Control (NCIPC, 2001) junto à população norte-americana, são apontadas algumas características de grande interesse para o entendimento da magnitude de causas externas enquanto problema de saúde pública. De um modo geral, traumas são problemas que afetam a toda a população, independentemente da raça, da idade, do sexo e do status sócio econômico. Essa característica se manifesta tanto como uma das principais causas de morte, de sofrimento e inconvenientes temporários, bem como de incapacidades, naquele país. Esses agravos têm também como característica afetar não só a sua vítima direta, como também a todos aqueles que se relacionam com ela. Mas apesar de atingir a todos, as causas externas apresentam diferentes padrões de ocorrência nos diferentes grupos populacionais. Assim, nos EUA, como já se viu em relação ao Brasil, os indivíduos do sexo masculino são os mais atingidos. Estudos efetuados durante a década de 90 permitem as algumas constatações (NCIPC, 2001):

- homens têm pelo menos quatro vezes mais chances que as mulheres de vir a morrer por suicidio;

- a mais alta taxa de suicídios ocorre entre os homens com mais de 65 anos de idade;

- mais de três quartos de homicídios e suicidios em escolas têm homens como vítima;

- ocorrem três vezes mais lesões traumáticas do encéfalo entre homens do que entre mulheres;

- ocorrem quatro vezes mais lesões traumáticas medula espinhal entre homens do que entre mulheres;

- em homens de 65 anos ou mais as taxas de lesões relacionadas a acidentes com veículos a motor são o dobro das das mulheres;

- alunos de sexo masculino do segundo grau das escolas norte-americanas 
utilizam o cinto de segurança em menor escala do que as alunas;

- homens de 65 anos ou mais têm taxas de óbitos $22 \%$ maiores que a das mulheres em relação às quedas;

- $80 \%$ dos afogamentos acontece entre os homens;

- a taxa de mortalidade entre pedestres acidentados é duas vezes maior entre os homens que entre as mulheres;

- meninos entre cinco e nove anos têm maior chance de serem agredidos por cães do que as meninas.

Este risco aumentado para homens decorre de muitos fatores. Entre eles, homens mais freqüentemente que as mulheres desenvolvem comportamentos que o colocam em risco, tais como dirigir após o uso de bebidas alcoólicas, não uso de cintos de segurança, participação em atividades de lazer e esportes potencialmente perigosos e a participar de atos de violência.

O estudo da NCIPC (2001) mostra algumas áreas que o risco das mulheres é muito main:

- as mulheres apresentam um número maior de tentativas de suicídio que os homens;

- num estudo norte-americano, de abrangência nacional, $25 \%$ das mulheres relataram ter sofrido algum tipo de violência física ou sexual por parte de seu parceiro em alguma época de suas vidas contra apenas $8 \%$ dos homens;

- uma em três mulheres ferida em conseqüência de violência física ou sexual demandou cuidados médicos;

- as mulheres são mais assassinadas por seus parceiros do que os homens;

- mulheres com 65 anos ou mais sofrem três vezes mais hospitalizações ocasionadas por fraturas do colo do fêmur que os homens.

São também relatadas importantes desigualdades de ocorrência de eventos quando são levadas em conta as diferenças étnicas daquela população (NCIPC, 2001).

Violência contra crianças:

A Organização Mundial de saúde (OMS) estima que 40 milhões de crianças sofram violências no mundo. A maioria dos menores submetidos a castigos corporais 
se encontra entre os dois e sete anos de idade (CONCHA-EASTMAN \& VILLAVECES, 2001).

Só no Brasil de 7 a 8 milhões de meninas e meninos entre cinco e dezoito anos vivem e trabalham nas ruas das cidades. Com frequiência estas crianças são vítimas de violentas perseguições por traficantes de drogas e pela polícia. A violència sexual também é comum contra crianças de ambos os sexos na América Latina Estima-se que pelo menos oitocentas mil meninas vivam nas ruas do Brasil e que muitas delas sobrevivam prostituição.

Crianças de zero a quatro anos (NCIPC, 2001):

- entre as idades de um a quatro anos as principais causas de morte são os acidentes de transporte;

- $50 \%$ das crianças que morrem em acidentes por veículo a motor não utilizava qualquer tipo de proteção;

- traumas da cabeça, como resultado de sacudidelas violentas, são a principal causa de morte e incapacidade entre crianças maltratadas e que sofrem abusos;

Crianças de cinco a quatorze anos:

- acidentes por veículo a motor são a principal causa de morte;

- apenas $6 \%$ das crianças entre quatro e oito anos se utiliza de assentos apropriados para sua segurança em automóveis;

- dois terços dos indivíduos menores de quinze anos que morrem em acidentes de trânsito, relacionados ao consumo de bebidas alcoólicas, eram passageiros de veículos cujos motoristas se encontravam alcoolizados;

- a taxa de suicidios cresceu entre as crianças de dez a quatorze anos em $109 \%$ no período de 1980 a 1997 e é a terceira causa de morte;

- por volta de 140.000 crianças são tratadas em serviços de urgência e emergência todos os anos nos EUA devido a lesões cerebrais traumáticas ocasionadas por acidentes de bicicletas;

- em 1998, 11\% das mortes por atropelamento e 30\% de suas ocorrências não-fatais foram em crianças com menos de quinze anos de idade; 
- crianças têm um risco aumentado de sofrerem lesões por mordedura de cães que os adultos. $2,5 \%$ destas são mordidas por ano em relação a 1,6\% dos adultos;

- $30 \%$ das violências sexuais acontecem antes dos doze anos de idade.

Jovens de quinze a vinte e nove anos:

- homicídio é a segunda principal causa de morte para norte-americanos entre quinze e dezenove anos. Em 1997, 85\% das jovens vítimas de homicidio foi morta por armas de fogo;

- suicídio é a terceira causa de morte nesta faixa etária;

- neste grupo o risco de ser vítima de um acidente de trânsito é maior que em qualquer outra faixa etária;

- em 1998, 21\% dos motoristas entre quinze e vinte e um anos de idade que faleceram em acidentes por veículo a motor tinha concentrações de álcool no sangue iguais ou superiores a $0,10 \%$;

- mais da metade das vítimas de lesões medulares têm entre quinze e trinta anos;

Idosos norte-americanos:

- os idosos americanos têm uma maior taxa de acidentes de trânsito por quilômetro dirigido que os jovens:

- a taxa de mortalidade por acidentes com pedestres é mais alta entre pessoas acima dos sessenta e cinco anos do que em qualquer outra faixa etária;

- nesta faixa etária as principais causas externas de mortalidade são as quedas;

- fraturas do colo do fêmur são os principais traumatismos relacionados às quedas. Metade dos idosos acometidos por esses agravos nunca mais retornam aos seus niveis funcionais prévios;

- $20 \%$ dos suicídios ocorrem entre os idosos.

No periodo 2000-01, nos EUA, foi estimado um custo financeiro para as causas externas de 224 bilhões de dólares anuais. Neste valor se incluem cuidados 
médicos diretos, reabilitação fisica, perdas salariais e de produtividade (NCIPC, 2001). Com custos médico-hospitalares diretos os gastos foram de $\$ 12,6$ bilhões de dólares. IUNES (1997) informou que, no Brasil, em novembro de 1994, os gastos hospitalares com internações devidas a lesões e envenenamentos, em hospitais cadastrados junto ao Sistema Único de Saúde (SUS), atingiram, em valores corrigidos para 1995, RS 23.923.861,94. É importante ressaltar que nessa ocasião o valor do Real estava ao par do dólar norte- americano. $O$ autor estimou o gasto total do ano de $1994 \mathrm{em}$ R\$287.086.343,33.

\subsubsection{Algumas caracteristicas da morbidade e da mortalidade por tipos de causas externas}

No Brasil são raros os trabalhos que apresentem este tipo de dados, principalmente quando se trata de morbidade. Nos EUA existem estudos que oferecem informações com grande detalhamento a este respeito. O NCIPC (2001) mostra que os problemas ocasionados pelas causas externas apresentam diversos padrões de ocorrência:

a- Consumo de bebidas alcoólicas

O consumo de bebidas alcoólicas é importante fator de risco em mais de cem mil óbitos anuais nos EUA. Neste país, de 20 a 30\% dos pacientes atendidos em serviços de emergência se apresentam após consumo de álcool. Uma grande proporção das mortes relacionadas com acidentes de transporte, com atividades de recreação na água,bem como, com o desencadeamento de incêndios domiciliares, com comportamentos violentos (quatro em dez vítimas), e ainda dois terços das vítimas de violência doméstica estão associados ao uso exagerado de bebidas alcoólicas. Metade das mortes em que se detectou o abuso do álcool são devidas a causas externas (acidentes de trânsito, quedas, fogo, afogamentos, homicídios, suicidios).

\section{b- Traumas e óbitos relacionados à bicicleta}

Nos EUA quinhentas mil pessoas ao ano sofrem de alguma lesão devido a acidentes relacionados com bicicletas. Em 1999, 750 ciclistas faleceram em 
acidentes. Destes um quarto eram crianças entre cinco e quinze anos. Aproximadamente 140 mil crianças são atendidas em serviços de emergência por traumas ocasionados por acidentes com bicicletas.

c- Violência contra a criança

Em 1998 mais de 900 mil crianças nos EUA sofreram ou estiveram sob risco de abuso e/ou negligência. Estima-se que por volta de 1.100 crianças morreram devido a maus-tratos.

d- Segurança da criança em veículos a motor.

A partir do primeiro ano de vida, acidentes de transporte são a principal causa de óbitos em crianças de todas as idades. Trata-se do mais importante problema de saúde pública para as crianças dos EUA. A cada noventa segundos uma criança é morta ou sofre algum agravo à saủde causado por acidentes de trânsito.

e- Lesões por mordedura de cães.

A cada quarenta segundos alguém procura assistência médica nos EUA devido a mordedura de cão. De 1979 a 1998 ataques destes animais ocasionaram 300 óbitos. Em 1994, 800 mil pessoas procuraram atendimento por esse motivo, sendo que $50 \%$ destes eram menores de dezoito anos de idade. Neste mesmo ano estimouse que 4,7 milhões de norte-americanos foram mordidos por um cão.

\section{f- Queda de idosos}

Nos EUA, a cada hora morre um adulto como resultado de queda. Em 1998 morreram 9.600 pessoas com mais de sessenta e cinco anos de idade por agravos ocasionados por elas. Cerca de trezentos mil idosos sofrem de fraturas do colo do fềmur provocadas por quedas todos os anos.

g- Violência entre cônjuges

É a maior causa de lesões e traumas ocasionados por violências. Acomete principalmente às mulheres. Em 1998, 32\% das mulheres vítimas de homicídio foi morta por seu parceiro contrastando com as cifras de $4 \%$ para os homens. 
h- Acidentes de transporte

Em 1999, nos EUA, três milhões de indivíduos foram vítimas de acidentes de transporte sendo que 42 mil destes foram a óbito. Entre os que morreram 5.586 eram adolescentes, 2.055 crianças e oito mil eram maiores de sessenta e cinco anos. $\mathrm{O}$ consumo de bebidas alcoólicas esteve envolvido em $38 \%$ dos acidentes fatais. Neste tópico é importante destacar o problema dos motoristas idosos, que estão mais expostos a riscos de serem vítimas de acidentes pelas limitações oriundas do processo natural de envelhecimento. Outro grupo que deve ser alvo de atenção especial é o dos pedestres sobre os quais ocorre um alto número de óbitos e lesões. Só no ano de 1999 perto de cinco mil pedestres faleceram devido a lesões originárias de acidentes de trânsito bem como oitenta e cinco mil foram vítimas de lesões nãofatais.

\section{i- Intoxicações}

Os envenenamentos, em 1999, nos EUA, acometeram 2,2 milhões de indivíduos levando 873 ao óbito. Das pessoas expostas a este problema $52,5 \%$ eram menores de seis anos de idade, sendo que mais de $90 \%$ das exposições ocorrem em casa.

j- Violência na escola

Um pouco menos de $1 \%$ de todos os homicídios que acontecem em idade escolar ocorrem no interior de escolas. Dois terços destes óbitos acometem estudantes.

\section{1- Violência sexual}

Cerca de 683 mil episódios de violência sexual ocorrem todos os anos nos EUA. Destes apenas $16 \%$ são notificados à polícia. Mais da metade acontecem em mulheres menores de dezoito anos, sendo que, por volta de $30 \%$ em meninas com menos de doze anos de idade.

\section{m-Suicídios}

Nos EUA morre-se mais por suicídio do que por homicídio. Em 1998, 30.575 
norte-americanos retiraram sua própria vida, numa média de 84 óbitos por dia. Neste mesmo ano estimou-se que ocorreram 671 mil visitas aos serviços de emergência como conseqüência de violências auto-infligidas.

n- Violência entre a juventude

Nos EUA recentemente houve a diminuição das taxas de homicidio. Entretanto é ainda a segunda mais importante causa de óbitos entre jovens de quinze a dezenove anos de idade, e é a primeira causa de morte entre afro-americanos de quinze a vinte e quatro anos. De 1992 a 1998, para cada vítima de homicidio com uma idade por volta dos doze anos aconteceram 121 traumatismos, dezesseis deles severos, devidos a violências interpessoais.

\subsection{Sistemas de Informação}

"Como as Informações em Saúde podem contribuir para um processo democrático emancipador do homem brasileiro e para a gestão e melhoria da saúde no terceiro milênio?' (MORAES, 2002). Esta questão deve perpassar a discussão da implantação e utilização dos sistemas de informação em saúde. É um grande desafio para todo o setor saúde. A autora trabalha com o entendimento de que "a 'informação', que só se efetiva no processo de interlocuções, vem se constituindo num artefato complexo, representação da complexidade da vida contemporânea. produzido historicamente, (...) devendo ser considerada um bem público."

A preocupação com informações em saúde remonta aos primórdios da medicina social. Segundo LAURENTI e cols. (1987), em 1662 através de trabalhos de John Graunt nasce a Estatística Vital. Na Inglaterra e na França no século XVII surgem preocupações com o tamanho e força das populações e inicia-se a coleta de dados sobre natalidade e mortalidade (FOUCAULT, 1996). Entre os componentes do paradigma denominado Medicina de Estado, que ocorre na Alemanha daquele século, estruturado na chamada polícia médica, certamente as atividades de esquadrinhamento da população, seguidas do registro das informações levantadas sobre sua saúde, suas estatísticas vitais e a utilização dos dados coletados nas decisões a serem tomadas são marcos históricos dos sistemas de informação em saúde. Ao mesmo tempo é nesse periodo que ocorre a "ruptura de uma medicina 
clássica para uma medicina moderna, que se funda no pensamento anátomo-clínico e nos princípios da patologia. Essa ruptura marca definitivamente a forma como as sociedades ocidentais, dai para frente irão desenvolver dispositivos que lidem com as questões relacionadas à vida, à gestão da vida. Dentre esses dispositivos encontra-se a implementação, paulatina e contínua, de inquéritos, levantamentos e/ou coletas de dados relacionados a indivíduos ou populações" (MORAES, 2002). A doença, que anteriormente a este período era considerada como portadora de uma essência abstrata, passa a ter sua significação corporificada no individuo: o portador do corpo doente. Isso possibilita a constituição de conhecimentos especificos, classificatórios, que resultarão na classificação das doenças e constituição de acervos de dados, que facilitam a comparação das patologias no tempo e no espaço.

A Organização Pan-americana de Saúde em seu plano de ação "Saúde e Violência" pontuou como um dos aspectos que necessita ser desenvolvido o "desenho de sistemas de informação sobre violência com procedimentos de classificação, registro e sistematização" (ORDONES \& VANOLLI, 1995). “A disponibilidade de informação apoiada em dados válidos e confiáveis é condição essencial para a análise objetiva da situação sanitária, assim como para a tomada de decisões baseadas em evidências e para a programação de ações de saúde" (RIPSA, 2002). "A informação é essencial à tomada de decisões. O conhecimento sobre a situação de saúde requer informações sobre o perfil de morbidade e mortalidade, os principais fatores de risco e seus determinantes, as caracteristicas demográficas e informações sobre serviços, como a disponibilidade de recursos humanos, infraestrutura e financeiros" (MOTA \& CARVALHO, 1999). "Se constitui no fator desencadeador do processo 'informação-decisão-ação', triade que sintetiza a dinâmica de suas atividades" (MINISTÉRIO DA SAÚDE, FUNASA, 2002). O sistema de informações é o esteio para a gestão dos serviços. Informação é fonte de conhecimento indispensável tanto para a formulação de políticas, planos e programas de saúde, bem como para o planejamento e avaliação dos serviços e ações do setor, e ainda, como ferramenta fundamental para atuação sobre os agravos à saúde nas perspectivas coletiva e individual. Além do suporte à gestão dos serviços, as informações orientam a implantação dos modelos de atenção, de promoção da saúde e das ações de prevenção e controle. "A busca de medidas do estado de saúde da 
população é uma antiga tradição em saúde pública, iniciada com o registro sistemático de dados de mortalidade e de sobrevivência" (RIPSA, 2002).

"O Sistema é um conjunto integrado de partes que se articulam com uma finalidade comum" (SANCHES e cols., 2001). Nos sistemas de informação, estas partes são os vários elementos ligados à captação, registro e difusão de dados que atuam integrada e articuladamente, com o propósito de atender às demandas, para o qual foi concebido. Também pode ser definido como "reunião de pessoas e máquinas, que visam à obtenção e processamento de dados que atendam à necessidade de informação da instituição que o implementa". Outra definição: "conjunto de estruturas administrativas e unidades de produção, perfeitamente articuladas,com vistas à obtenção de dados, mediante o seu registro, coleta, processamento, análise, transformação dos dados em informação e a sua oportuna divulgação" (MINISTÉRIO DA SAÚDE, FUNASA, 2002). Estes compreendem desde as fichas, prontuários e outros elementos para captar os dados, passando por gráficos, tabelas, etc, que ajudam na visualização e descrição dos dados e ainda recursos usados para sua análise e transformação tais como computadores além de outras ferramentas. Para que se produza o conhecimento adequado e oportuno é necessário que se utilize a tecnologia adequada às necessidades do sistema de saúde, bem como, que se racionalize a obtenção de dados com sua posterior análise.

Segundo SANCHES e cols. (2001) "uma caracteristica fundamental dos sistemas de informação è a sua capacidade de coligir um número amplo de registros, armazená-los e recuperá-los. Este segmento especifico de um sistema de informações corresponde à função dos bancos de dados".

Dado é definido "como um valor quantitativo referente a um fato ou circunstância" ou "o número bruto que ainda não sofreu qualquer espécie de tratamento estatistico", ou ainda, "a matéria prima da produção da informação". Já informação é entendida como "o conhecimento obtido a partir dos dados" ou "o dado trabalhado" ou "o resultado da análise e combinação de vários dados", o que implica em interpretação por parte do usuário. É "uma descrição de uma situação real, associada a um referencial explicativo sistemático" (MINISTÉRIO DA SAÚDE, FUNASA, 2002).

De uma maneira geral, no setor saúde, os dados coletados por sistemas de 
informação são trabalhados sob a forma de indicadores de saúde. "Em termos gerais, os indicadores são medidas-sintese que contêm informação relevante sobre determinados atributos e dimensões do estado de saúde, bem como do desempenho do sistema de saúde. Vistos em conjunto, devem refletir a situação sanitária de uma população e servir para a vigilância das condições de saúde" (RIPSA, 2002).

A qualidade da informação depende de inúmeros fatores, dentre eles a qualidade dos indicadores. É necessário que o seu registro, coleta, transmissão, descrição e análise sejam precisos e cuidadosos. "O grau de excelência de um indicador deve ser definido por sua validade (capacidade de se medir o que se pretende) e confiabilidade (reproduzir os mesmos resultados quando aplicado em condições similares). Em geral, a validade de um indicador é determinada pelas características de sensibilidade (medir as alterações do fenômeno estudado) e especificidade (medir somente o fenòmeno analisado). Outros atributos da qualidade do indicador são sua mensurabilidade (basear-se em dados disponiveis fäceis de se conseguir), relevância (responder a prioridades de saúde) e custo-efetividade (os resultados justificam o investimento de tempo e recursos). (. . .) Para um conjunto de indicadores, são atributos de qualidade importantes a integridade (dados completos) e a consistência interna (valores coerentes e não-contraditórios)" (RIPSA, 2002).

Apesar de toda a importância que se revestem os agravos ocasionados pelas causas externas, na realidade, em nosso pais, se trata de assunto pouco estudado até agora. $\mathrm{Na}$ esfera da mortalidade os estudos são de maior consistência porque o Sistema de Informações sobre Mortalidade (SIM) se encontra em funcionamento desde 1975 (MELLO JORGE, 1990; ANDRADE, 1998). É fundamental que sejam efetuados esforços para que se aprofundem os conhecimentos dessa área fundamental da Saúde no Brasil. A Política Nacional de Redução da Morbimortalidade por Acidentes e Violências diz: "a melhoria das informações constituirá uma das prioridades à qual deverá ser concedida atenção especial. Uma das medidas será a promoção do registro contínuo, padronizado e adequado das informações, de modo a possibilitar estudos e elaboração de estratégias de intervenção acerca dos acidentes e das violências relacionados aos diferentes segmentos populacionais, segundo a natureza e o tipo de lesões e de causas, a partir dos quais viabilizar-se-á a retroalimentação do sistema, contribuindo, assim, para a melhoria do atendimento 
prestado a estes segmentos. A base para a implementação dessa medida estará representada pela elaboração de normas técnicas respectivas; adequação de instrumentos de registros, com a introdução de questões específicas para o diagnóstico de violências e de acidentes; e inclusão de novos procedimentos ou especificação do atendimento na tabela dos Sistemas de Informação Ambulatorial e Hospitalar: SIA e SIH/SUS" (BRASIL, 2001). Esta política nacional preconiza medidas para a monitorização da ocorrência dos eventos, ampliando a abrangência dos sistemas de informações de morbimortalidade principalmente através das seguintes propostas:

- promoção de auditoria da qualidade de informação dos sistemas;

- elaboração de normas destinadas a padronizar as fichas de atendimento pré-hospitalar e hospitalar, de forma a permitir o fornecimento do perfil epidemiológico do paciente atendido, incluindo tipos de lesões e tipos de causas externas e da identificação do acidente de trabalho;

- a criação de um sistema nacional de informação relativo ao atendimento pré-hospitalar;

- a otimização do sistema de informação de morbidade, de modo que incorpore dados epidemiológicos relativos a atendimentos em prontosocorros e ambulatórios;

- a efetivação do disposto na Portaria GM/MS n. ${ }^{\circ}$ 142/97, que determina a especificação do tipo de causa externa no prontuário médico e nas autorizações de internação hospitalar;

- a inclusão de "lesões e envenenamentos" com detalhamento do tipo de causas externas como agravos sujeitos à notificação, o que permitirá o conhecimento de casos atendidos em unidades de saúde não ligadas ao SUS e em nivel ambulatorial;

- o estabelecimento de ações padronizadas de vigilância epidemiológica para os casos de morbimortalidade de acidentes e de violências determinando, inclusive, os ratores de risco.

Essas ações deverão utilizar os sistemas de informação já existentes e metodologia uniforme; 
- a criação de um banco de dados que reúna as investigações epidemiológicas já desenvolvidas no País, visando à união de esforços e à otimização de recursos disponiveis;

- a inserção do serviço de informação toxicológica nos serviços de toxicologia - Centros de Intoxicação -, em hospitais de atendimento médico de urgência;

- a identificação e implementação de mecanismos que possibilitem a ampliação da cobertura de informação relativa aos acidentes de trabalho ocorridos no mercado informal, de modo a ultrapassar a concepção eminentemente previdenciária.

A monitorização da situação envolverá, também, o estabelecimento de ações de vigilância epidemiológica para os casos de morbimortalidade por acidentes e violências, estimulando-se experiências locais e a união de esforços nas áreas em que vários procedimentos já estão sendo desenvolvidos, com vistas a potencializares recursos disponiveis. Nesse contexto, deverão ser incentivados estudos amplos e consistentes acerca da morbimortalidade, inclusive com a determinação de seus possiveis fatores de risco.

Em relação a acidentes de trânsito, o sistema de vigilância epidemiológica compreenderá a implantação, com recurso eletrônico, de uma rede de informação estatística destes acidentes, que inclua a captação, o transporte e o armazenamento de dados. Esta rede deverá estar integrada e acessivel a todos os fóruns em nivel municipal, estadual e federal e possibilitar a análise não apenas dos dados de acidente, como também de outros parâmetros de segurança que auxiliem na identificação de causas e na proposta de medidas preventivas. A organização e o desenvolvimento das ações implicarão a definição de um boletim de ocorrência padrão e a formação de técnicos em vigilância epidemiológica de acidente de trânsito.

O setor saúde deverá participar da monitorização dos acidentes ampliados, levantando, junto com os outros órgãos, as causas, as conseqüências a curto e longo prazos, bem como os recursos envolvidos na sua mitigação (BRASIL, 2001). 


\subsubsection{Alguns dos sistemas de informação de abrangência nacional no Brasil}

No Brasil nos últimos anos, com a popularização do uso da informática e de seus recursos, tal como a Internet, foram disponibilizados sistemas de informação de abrangência nacional. Vem se procurando estabelecer bases informacionais compatibilizadas, que permitam o monitoramento das populações, de seu nascimento (SINASC - sistema de informações de nascidos vivos), até sua morte (SIM - sistema de informações sobre mortalidade), incluindo as intercorrências ambulatoriais e hospitalares (SIA - sistema de informações ambulatoriais e SIH - sistema de informações hospitalares). Entre estes serão descritos alguns:

- Sistema de informações sobre mortalidade (SIM) - Implantado pelo Ministério de Saúde desde 1975, utiliza instrumento padronizado para coleta de dados: a Declaração de Óbito. Informa características de tempo, pessoa e lugar, condições do óbito, assistência prestada ao paciente, bem como as causas básicas e as associadas ao evento.

- Sistema de informação sobre agravos de notificação (SINAN) - Tem como finalidade a vigilância epidemiológica de determinados agravos. O SINAM agrega agravos de diferentes naturezas: crônico-transmissiveis, nãotransmissiveis; agudos transmissíveis e não-transmissiveis. Utiliza alguns formulários padronizados: A Ficha Individual de Investigação configura-se na maioria das vezes como um roteiro de investigação, distinto para cada tipo de agravo. Ela permite obter dados que possibilitam a identificação da fonte de infeç̧ão e mecanismos de transmissão das doenças.

- Sistema de informações ambulatoriais do SUS (SIA-SUS) - "Oferece aos gestores estaduais e municipais de saúde, instrumentos para operacionalização das funções de cadastramento, controle orçamentário, controle e cálculo da produção e para a geração de informações necessárias ao Repasse do Custeio Ambulatorial (RCA). Oferece também informações para o gerenciamento de capacidade instalada e produzida, bem como dos recursos financeiros orçados e repassados aos prestadores de serviços" (disponível em http://www.datasus.gov.br/ em 25/02/02). Sua utilidade para fornecimento de dados sobre morbidade ambulatorial é extremamente limitada.

- Sistema de informações hospitalares do SUS (SIH-SUS) - O SIH-SUS contém 
informações que viabilizam efetuar o pagamento dos serviços hospitalares prestados pelo SUS, através da captação de dados relativos a mais de 1.300 .000 internações/mès. Dispõe de informações sobre recursos destinados a cada hospital que integra a rede do SUS, as principais causas de internações no Brasil, a relação dos procedimentos mais freqüentes realizados mensalmente em cada hospital, município e estado, entre outras.

- Sistema de informações de nascidos vivos (SINASC) - Implantado em 1990 estrutura-se de forma semelhante ao SIM, isto é com um instrumento padronizado de coleta de dados: a declaração de nascido vivo.

- Sistema de informações de atenção básica (SIAB) - É um sistema de informações territorializado, que coleta dados que possibilitam a construção de indicadores populacionais, referentes a áreas de abrangência bem delimitadas, cobertas pelo programa de Agentes Comunitários de Saúde e pelo Programa de Saúde da Familia.

- Sistema de informações de vigilância alimentar e nutricional (SISVAN) Disponibiliza informações sobre o programa de recuperação de crianças e gestantes desnutridas ou sobre risco nutricional.

- Sistema de informações do Programa Nacional de Imunizações (SI-PNI) fornece dados relativos à cobertura vacinal de rotina e em campanhas, taxa de abandono, e controle e envio de boletins de imunização.

- Sistema de informação de vigilância da qualidade da água para consumo humano (SISÁGUA) - foi estruturado para fornecer informações sobre a qualidade da água para consumo humano, proveniente de sistemas públicos e privados, e de soluções alternativas de abastecimento.

- Sistema de informações em saúde para os acidentes e violências/causas externas (SISAV) - criado pela portaria n. ${ }^{\circ} 970$ de 11/12/2002 como instrumento de registro de causas externas no âmbito do Sistema Único de Saúde, destinado à realização de estudos e pesquisas que deverão subsidiar o planejamento de ações de atenção, prevenção e recuperação das pessoas em situação de acidentes e violência. O sistema foi criado e passou por estudo piloto no Rio Grande do Sul e Amapá. Foram elaborados uma ficha e um programa de computador. Entretanto ainda não foi implantado. 


\subsubsection{Fontes de dados sobre causas externas utilizadas no Brasil}

As principais fontes de dados que podem trazer informações para conhecimento dos agravos à saúde ocasionados por acidentes e violências são:

- Sistema de Informações Hospitalares do Sistema Único de Saúde (SIH/SUS): se refere às informações já citadas anteriormente, coletadas pelas AIHs. Têm como inconveniente de apenas cobrir a rede SUS, não levando em conta os serviços de saúde privados. Não abrange dados de pronto-socorros;

- Sistema de Informações de Mortalidade do Ministério da Saúde (SIM/MS): dados coletados a partir das declarações de óbito;

- Comunicação de Acidentes de Trabalho/CAT: Sistema de abrangência nacional, gerido pelo Instituto Nacional de Seguro Social (INSS). É limitado pois exclui categorias de trabalhadores tais como os autônomos, os sem carteira assinada e os vinculados a outros tipos de previdência, rr.mn os funcionários públicos;

- Boletim do Departamento Nacional de Estradas de Rodagem (DNER): Dados referentes a acidentes de trânsito ocorridos em estradas federais, estaduais e municipais;

- Boletim de Ocorrência Policial (BO) Instrumento não-padronizado utilizado nas delegacias de polícia;

- Sistema Nacional de Informações Tóxico-Farmacológicas (SINITOX): Casos e óbitos por intoxicação humana no país. Abrangência muito pequena.

Esta relação mostra importantes limitações existentes para se reconhecer toda a abrangência dos problemas trazidos à saúde por violências e acidentes. Faltam, entre outras, fontes de informação que permitam a identificação dos eventos cuja gravidade não levam à internação ou à morte. Os BO, apesar de úteis, são extremamente limitados, o que não permite a sua utilização de rotina para coleta de informações que possam ser de utilidade no trabalho de promoção, prevenção e recuperação da saúde em causas externas. ANDRADE (1998) encontrou ao estudar acidentes de transporte, uma cobertura média de apenas $22,5 \%$ de registros em BO de vitimas atendidas em pronto-socorros. As informações diretamente colhidas em 
prontuários/fichas dos pronto-socorros também são muito pouco úteis para a vigilância e outras atividades pois, geralmente, estes não demonstram coerência entre os diversos profissionais que os preenchem, bem como quaisquer padronizações para o seu preenchimento. A "Política Nacional de Redução de Morbimortalidade por Acidentes e Violências" (BRASIL, 2001) assinala que "não existem sistemas de informação epidemiológica relacionados aos atendimentos em pronto-socorros e ambulatórios, e que contemplem estudos mais apurados relativos a acidentes e violências". Para os óbitos, apesar dos problemas já apontados, o SIM/MS assegura importantes informações. O mesmo acontece de forma bem mais limitada para os casos de internação, cobertas na rede do Sistema Único de Saúde pelo SIH/SUS. DESLANDES (1999) coloca que "em nenhum outro serviço de saúde a violência adquire tamanha visibilidade como na emergência. (...) Podemos mesmo dizer que o atendimento de emergência, é um poderoso indicador da violência que ocorre na cidade.

No diagrama apresentado na figura 1, desenvolvido por Mello Jorge (1997 B), pode-se acrescentar as coberturas de cada possível fonte de informações:

Figura 1 - Cobertura por parte das diversas fontes de informação existentes das ocorrências em causas externas

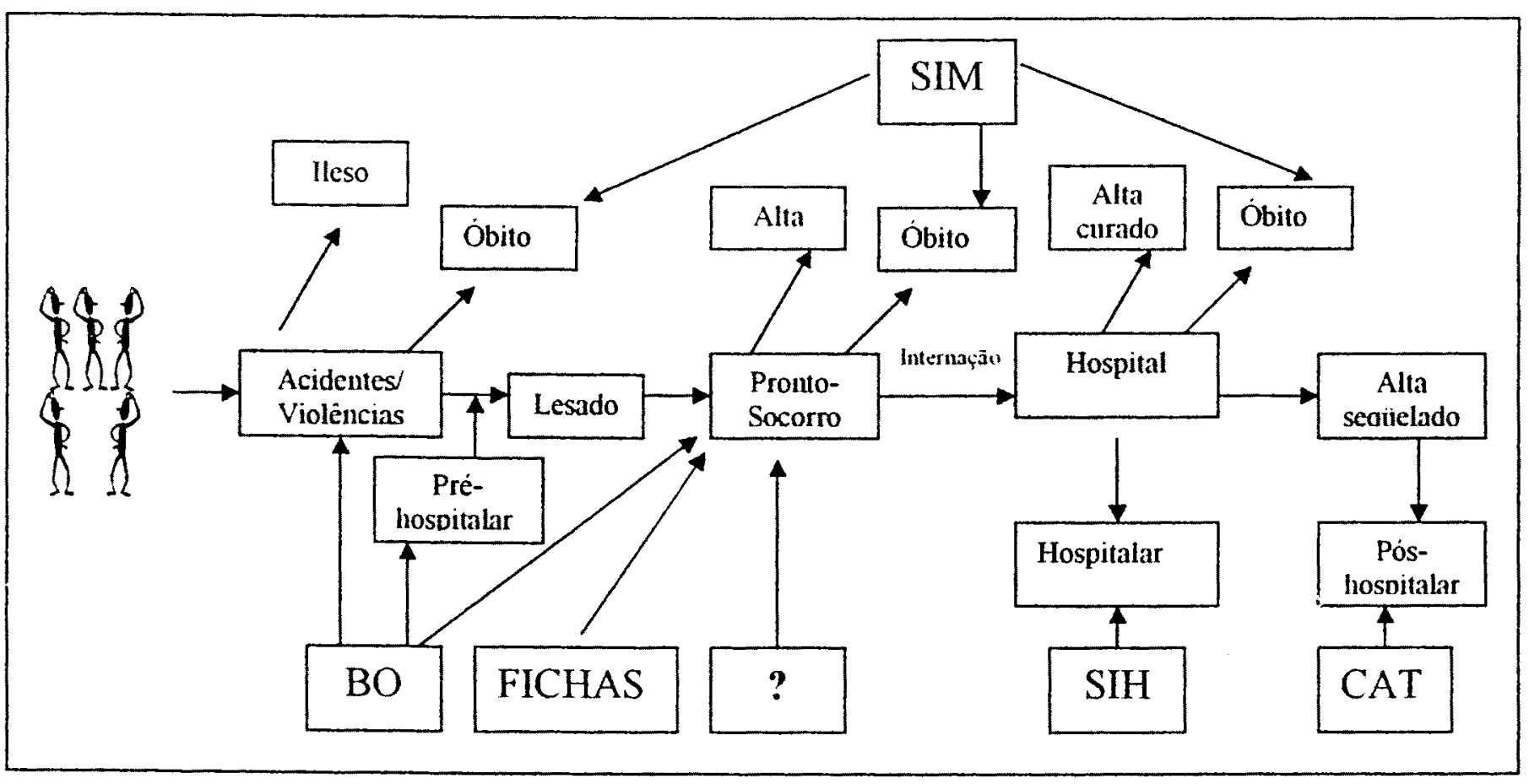

Fonte: Mello Jorge, 1997 B 
Na figura 1 pode-se verificar a população exposta a acidentes/violências, possíveis condições das vitimas, niveis de prevenção de diferentes etapas do processo e abrangência das diferentes fontes de informação. A área de atendimento préhospitalar não conta com fontes de informação sistematizadas. No pronto-socorro, local de convergència da maior parte das vítimas de violências e de acidentes, também não existe nenhum tipo sistematizado, de caráter oficial, de coleta de dados epidemiológicos a respeito de causas externas de lesão. $\mathrm{O}$ máximo que se encontra são prontuários, que na maioria das vezes, como jả se informou anteriormente, são preenchidos sem quaisquer padronizações ou critérios, a bel prazer daquele que executa essa tarefa. Tal fato acarreta na perda de importantíssima parcela das informações que pode desempenhar papel fundamental no equacionamento deste importante problema. A coleta sistemática destas e de outras informações, que são rotineiramente perdidas, pode levar a um substancial ganho tanto num prisma qualitativo como no quantitativo, aos programas de combate e prevenção destes agravos à saúde.

\subsubsection{A Qualidade das Informações em Causas Externas}

A qualidade da informação no Brasil é ainda problemática. WALDMAN \& MELLO JORGE (1999) estimam que 10\% dos óbitos totais do Brasil estão mal detalhados no Sistema de Informações de Mortalidade do Ministério da Saúde (SIM/MS). Além disso, a qualidade desses dados é afetada pelo grande número de notificações de óbitos classificados como ocasionados por "sintomas e estados mórbidos mal-definidos ou "sem assistência médica", portanto, de causa desconhecida (MELLO JORGE, GAWRYSZEWSKI \& LATORRE, 1997).

Em relação às causas externas, as Declarações de Óbitos, apesar de constituirem boa fonte de informações do ponto de vista quantitativo, com dados que demonstram a gravidade do problema, qualitativamente deixam muito a desejar. A situação, em nosso meio, se revela ainda mais séria quando se constata que as informações a respeito de mortalidade por causas externas são subnotificadas. e apresentam falhas quanto à sua qualidade. Uma razão apontada por MELLO JORGE, GAWRYSZEWSKI \& LATORRE (1997) para esse fato é que: "na parte internacional do modelo da Declaração de Óbito (atestado médico) - local destinado 
à colocação das causas de óbito - os legistas, após necrópsia, às vezes, em número não pequeno de casos, fazem menção à natureza das lesões que levaram à morte sem se referirem aos tipos de acidentes/violências que ocasionaram essas lesões (...). É esse o motivo pelo qual vão ocorrer óbitos por "causas externas do tipo ignorado", para algumas áreas. em quantidade não desprezivel'.

No Brasil. em 1994, estas causas de tipo ignorado chegaram, segundo as mesmas autoras, a $11,9 \%$ dos óbitos por causas externas, atingindo em capitais como o Rio de Janeiro a percentuais situados em $54,8 \%$. Historicamente esse grupo de causas vem se mantendo por volta de $15,0 \%$ prejudicando enormemente os programas de prevenção a serem desenvolvidos nesta área. A percentagem de mortes por causas externas no Brasil "em que não se sabe se decorrentes de homicídio, suicídio ou acidente foi estimada ao redor de $10,0 \%$ no final da década de 90 , embora em época não muito distante chegasse a mais de 50,0\% em alguns municípios brasileiros, como no Rio de Janeiro" (MELLO JORGE, GOTLIEB \& LAURENTI, 2002).

Informações referentes a vítimas não-fatais de violências ainda são de pior qualidade. Não existe um sistema estruturado que permita sua captação. "No Brasil, somente são conhecidos os dados de hospitalizações pagas pelo Sistema Único de Saúde (SUS), que têm início com o documento Autorização de Internação Hospitalar $(\mathrm{AIH})$, preenchido nos hospitais, obrigatório para recebimento de pagamento referentes a essas internações" (WALDMAN \& MELLO JORGE, 1999). Estas informações, por serem geradas com finalidades administrativas, contribuem pouco para o conhecimento das caracteristicas reais das circunstâncias, das lesões, dos fatores de risco e/ou de proteção associados. Além disso, não existe o preenchimento das AIH ou de qualquer outra fonte de informação em ambiente de pronto-socorro, onde se concentra a maior parte dos atendimentos às vítimas de causas externas.

ANDRADE (1998), demonstrou este fato: trabalhando com inúmeras fontes de dados, observou que apenas $22,5 \%$ das vítimas de acidentes de transporte terrestre, atendidas em pronto-socorro, foram captadas pelos registros policiais, em comparação a $48,8 \%$ das internadas e $86,2 \%$ das falecidas. O Sistema de Informações sobre acidentes de trabalho (SISCAT) não captou 46,8\% de acidentados que eram concomitantemente vítimas de acidentes de trabalho e dos de trânsito. A 
má qualidade da informação é evidente quando se verifica que as fichas de prontosocorro, de internação e as declarações de óbito apresentaram um percentual de causas externas de tipo ignorado de $9,2 \%, 38,4 \%$ e $35,4 \%$. Quanto a acidentes de trânsito de tipo não especificado encontrou-se, respectivamente, $18,0 \%, 10,9 \% \mathrm{e}$ $44,6 \%$. Além disso, usou-se indevidamente o termo "atropelamento" para ciclistas e motociclistas que colidiram com outros veículos.

\subsubsection{Fluxos de alguns sistemas de informação em saúde no Brasil}

Para que se possa operacionalizar de maneira efetiva um Sistema de Informações em Saúde é necessário que sejam estabelecidos fluxos adequados para a coleta, processamento e análise dos dados. Nas figuras 1, 2 e 3 estão exemplificados, de maneira esquemática os fluxos de três sistemas de informações brasileiros: o SIM (LAURENTI \& MELLO JORGE, 1996), , o SINAN (MS, FUNASA, 2002) e o SIH/SUS (MS, FUNASA, 2002). Outro importante Sistema é o SINASC (MELLO JORGE e cols, 1992) que trata da informação a respeito de nascidos vivos. 
Figura 2- Fluxo de informações para óbitos no SIM

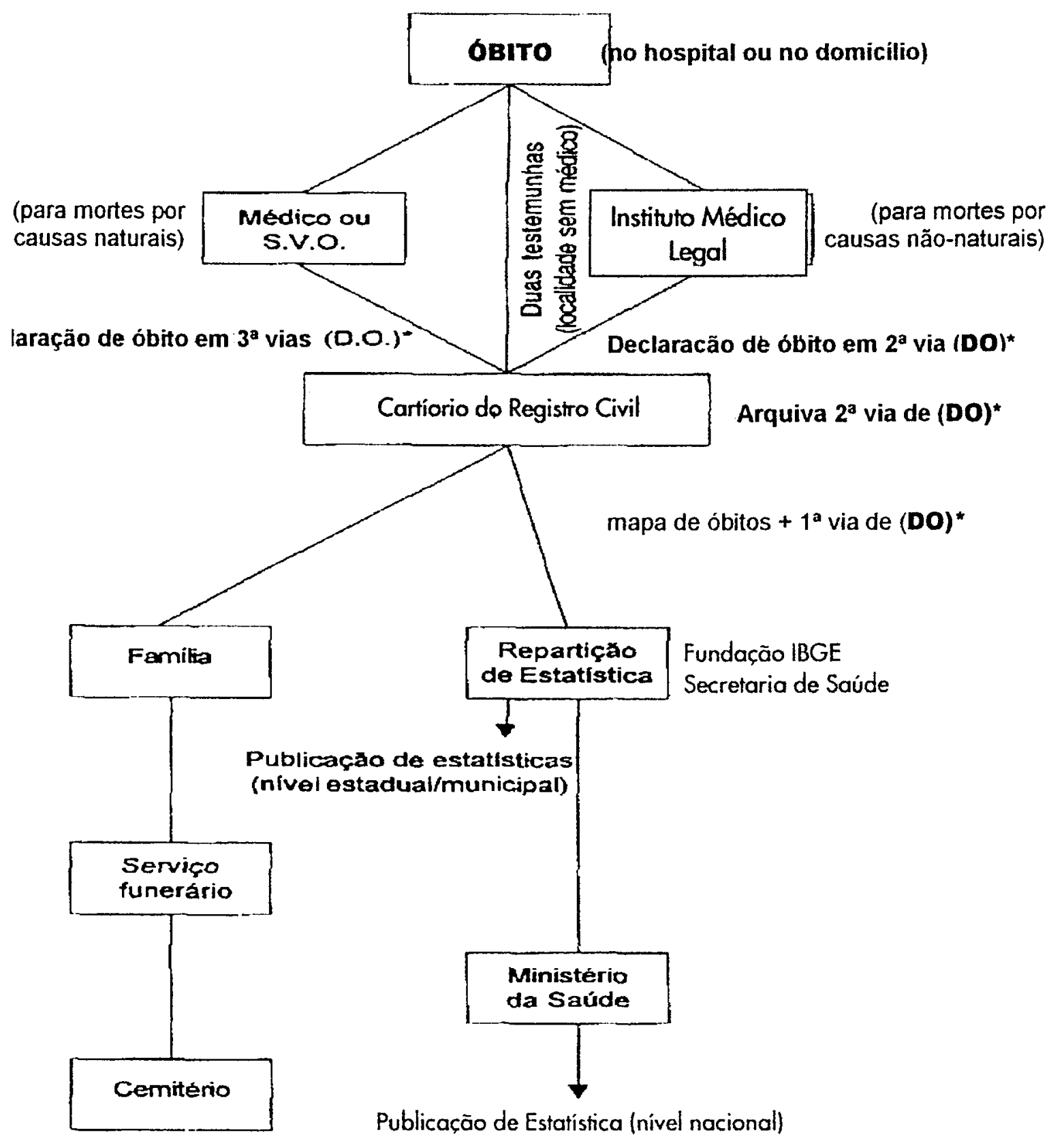

*Sugere-se que as instituições fiquem com uma via para ser retirada pelos serviços de Estatística. FONTE: LAURENTI, R \& MELLO JORGE, MHP - O atestado de óbito - São Paulo: OMS/ NEPS/USP, 1996. $87 \mathrm{p}$. 
Figura 3 - Fluxo de Informações do SINAN

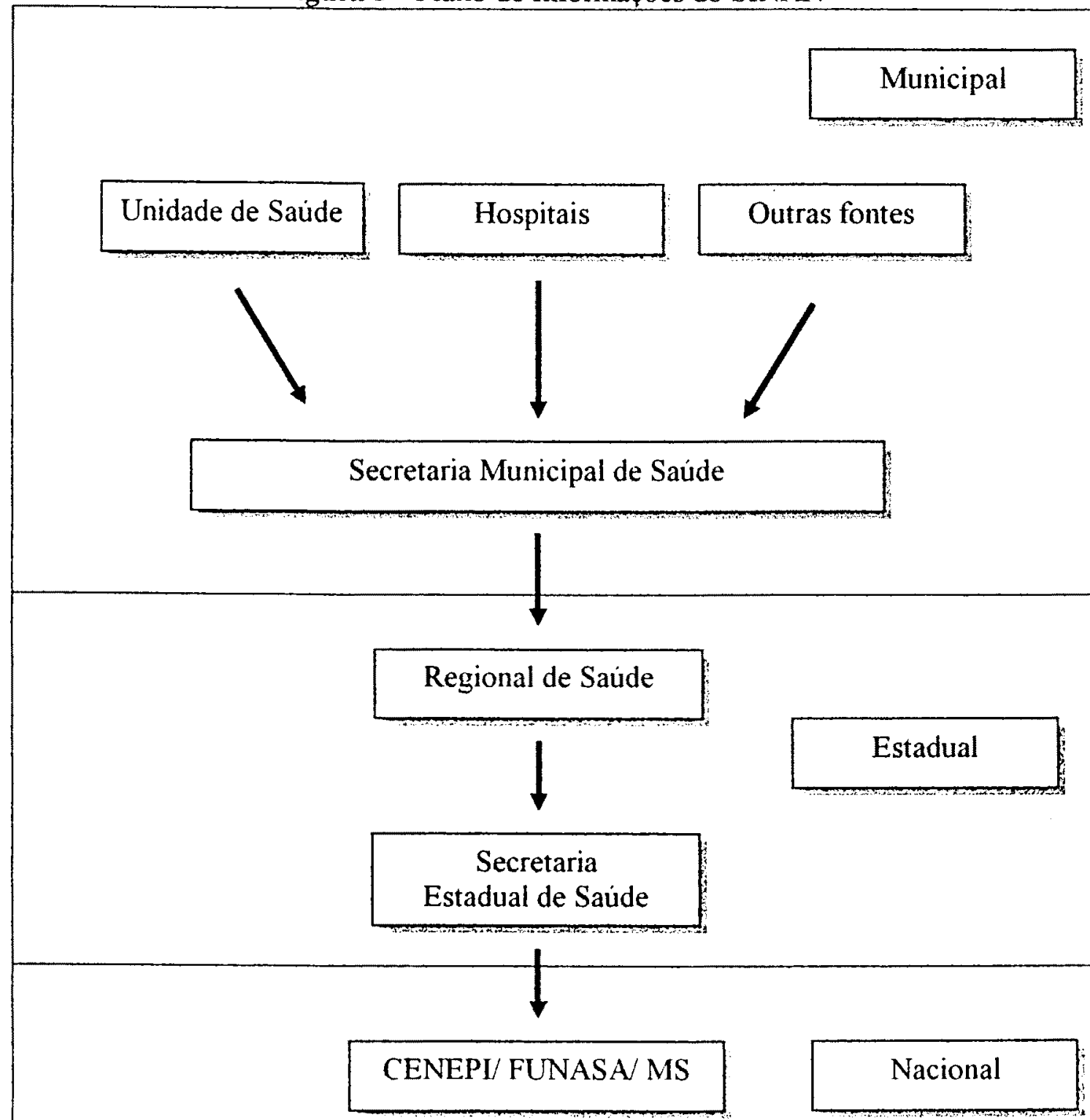

FONTE: MS, FUNASA, 2002, P. 64.

Propõe-se que as Fichas Individuais de Notificação (FIN), sejam preenchidas pelos profissionais de saúde nas unidades assistenciais, e que essas mantenham uma segunda via arquivada, enquanto remetem a original para o serviço encarregado de desencadear as medidas de controle necessárias. Este serviço, além de desencadear as medidas de controle necessárias, digitará os dados e os remeterá para a Secretaria Municipal de Saúde, que os remeterá para as Secretarias Estaduais e, estas, para a FUNASA 
Figura 4 - Fluxo básico de Autorização de Internação Hospitalar (AIH)

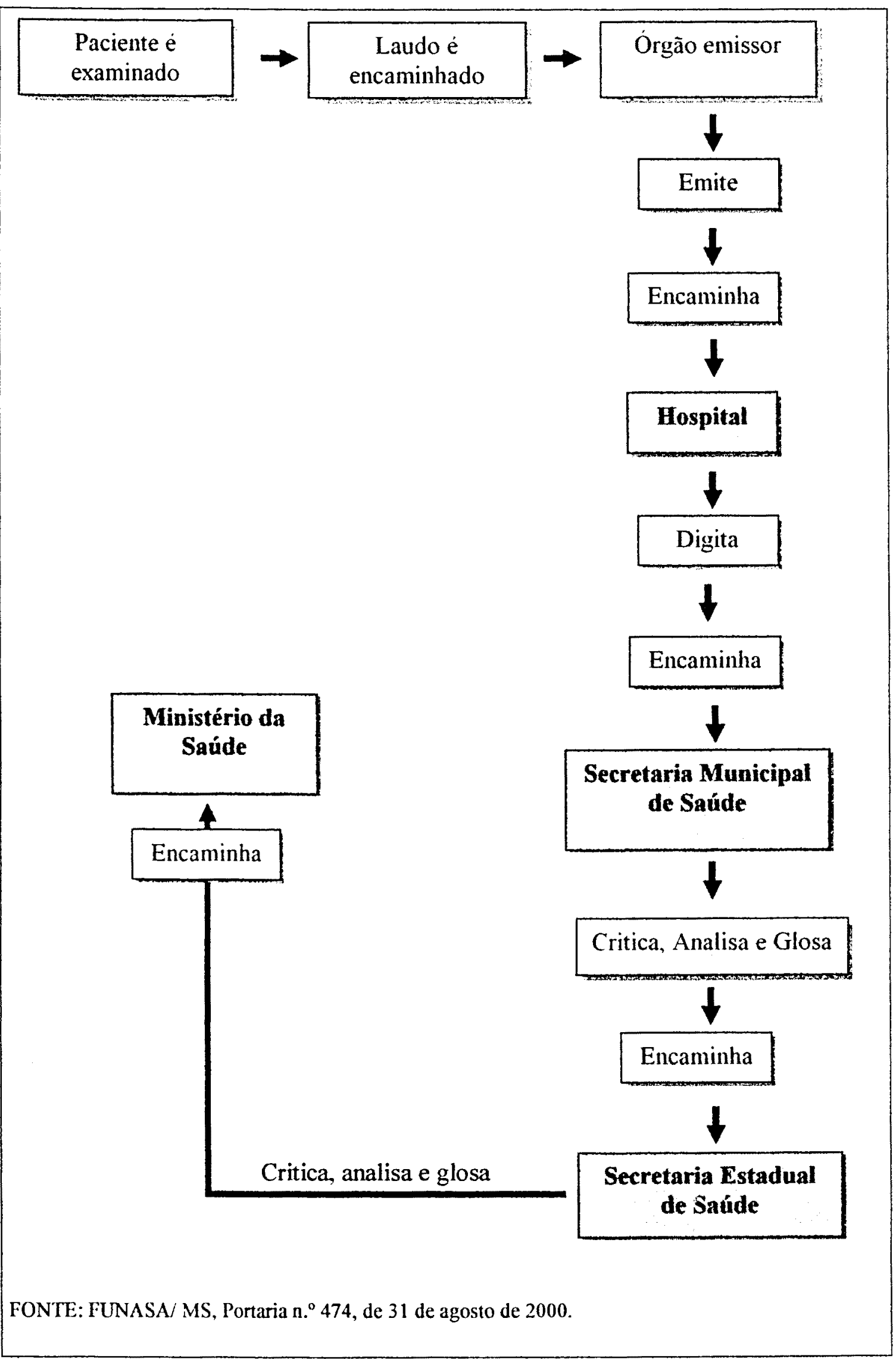




\subsection{A Prevenção}

Será possivel a prevenção das violências? Onde atuar? Estas são questões que ainda estão para ser respondidas. O tema é polêmico e envolve inúmeras posições. MINAYO \& SOUZA (1999) afirmam que para o senso comum prevenção significa antecipação da decisão sobre uma situação de risco. Já LEAVELL \& CLARK (1976) dizem que a intervenção sobre problemas de saúde deve-se dar através de ações de Prevenção Primária (promoção da saúde e proteção especifica), Prevenção Secundária (diagnóstico e atendimento precoce e limitação do dano) e Prevenção Terciária (reabilitação). Esta visão tem a importância de tratar ações que redundam na elevação da qualidade de vida (promoção) como um dos estágios integrantes da atuação dos serviços de saúde. De acordo com BUSS (1998) promoção da saúde abrange um conjunto de valores como: vida, solidariedade, eqüidade, participação, parceria; e de algumas estratégias: ações do estado, da comunidade, dos indivíduos; e promove uma múltipla responsabilização pelos problemas que afetam a qualidade de vida e a saúde. O enfoque de LEAVELL \& CLARK apesar de apresentar aspectos discutiveis tem sua importância na medida que ajuda no entendimento dos cuidados e da assistência relativa aos agravos e lesões orientando a praxis dos profissionais no cotidiano do serviço (MINAYO \& SOUZA 1999). Em 1970, William Haddon Jr. propôs um modelo para análise dos agravos à saúde causados por violências e acidentes. Este instrumento se apresenta na forma de uma matriz que combina fatores ligados ao tempo (antes, durante e depois da ocorrência do evento), fatores ligados ao indivíduo que é afetado, ao agente da lesão e ao ambiente físico e ao sócioeconômico (tempo/pessoa/lugar). Trata-se de modelo de clara inspiração no de LEAVELL \& CLARK (1976), que tem tido relativo sucesso na abordagem da prevenção da ocorrência e das conseqüências de causas externas em paises como os EUA (HOLDER, PEDEN, KRUG, 2001). O quadro 1 mostra a matriz de Haddon. 
Quadro 1 - Matriz de Haddon

\begin{tabular}{|c|c|c|c|c|}
\hline & $\begin{array}{l}\text { Fator Humano } \\
\text { (Vítima) }\end{array}$ & $\begin{array}{l}\text { Vetor ( agente } \\
\text { da lesão) }\end{array}$ & Ambiente físico & $\begin{array}{l}\text { Ambiente sócio- } \\
\text { econômico }\end{array}$ \\
\hline $\begin{array}{l}\text { Pré- } \\
\text { evento }\end{array}$ & $\begin{array}{c}\text { Está predisposto } \\
\text { superexposto ao risco? }\end{array}$ & $\begin{array}{l}\text { O agente é } \\
\text { perigoso? }\end{array}$ & $\begin{array}{l}\text { - O meio ambiente é } \\
\text { perigoso? } \\
\text { - Ele tem componentes } \\
\text { propicios redução de riscos? }\end{array}$ & $\begin{array}{l}\text { O ambiente encoraja ou } \\
\text { desencoraja a exposição } \\
\text { ao risco e ao perigo? }\end{array}$ \\
\hline Evento & $\begin{array}{l}\text { A vitima é capaz de } \\
\text { tolerar a cnergia } \\
\text { mecânica ou a força } \\
\text { transferida? }\end{array}$ & $\begin{array}{l}\text { O vetor demanda } \\
\text { proteção? }\end{array}$ & $\begin{array}{l}\text { O ambiente contribui para a } \\
\text { duração do evento? }\end{array}$ & $\begin{array}{l}\text { O ambiente contribui } \\
\text { para a duração do } \\
\text { evento? }\end{array}$ \\
\hline $\begin{array}{l}\text { Pos- } \\
\text { evento }\end{array}$ & $\begin{array}{l}\text { Qual a severidade do } \\
\text { trauma ou do dano? }\end{array}$ & $\begin{array}{l}\text { O vetor conuribui } \\
\text { para o trauma? }\end{array}$ & $\begin{array}{l}\text { O ambiente amplia o trauma } \\
\text { após o evento? }\end{array}$ & $\begin{array}{l}\text { O ambiente é propício à } \\
\text { recuperação? }\end{array}$ \\
\hline
\end{tabular}

Fonte: HADDON adaptado por HOLDER, Y.; PEDEN,M.; KRUG, E. e cols. (eds.) - Injury surveillance guideline, 1 ed. Geneva, World Health Organization, 2001. p. 9.

Trata-se de modelo que apresenta, por sua abordagem individualizada do problema das causas externas, inúmeras limitações, mas que pode ter grande utilidade para a compreensão destes eventos, pela sua simplicidade e objetividade. Também pode ser destacado o fato dela focalizar o evento de forma integral.

Na década de 70, outro modelo, o esquema quadridimensional de LALONDE (1974) coloca quatro determinantes da situação de saúde da população em pauta: o estilo de vida, a biologia humana. o ambiente e os serviços de saúde. Essa visão facilita a compreensão de que saúde e os seus problemas não se situam exclusivamente no âmbito de questões médico-biológicas, mas numa perspectiva de ser resultante de muitos fatores e que as suas práticas devem levar em conta o conjunto de determinantes. Este modelo permite integrar o tema da prevenção da violência "no âmbito das políticas e propostas de mudanças sociais e ambientais e incluí-lo nos projetos de ambiente saudável e qualidade de vida" (MINAYO \& SOUZA 1999).

Na visão de MINAYO \& SOUZA (1999) "qualquer projeto de prevenção da violência deve levar em conta a complexidade desse fenômeno que possui raízes 
macro-estruturais, formas de expressão conjunturais e atualização na cotidianidade das relações interpessoais. O papel do setor saúde é o de liderar ações especificas intersetoriais e de militância cidadã, buscando promover a qualidade de vida, ambiente saudável, incorporação de direitos, e superação de processos de dominação, exclusão e de violência fisica, moral e emocional. Dentro de ações especificas, investir na prevenção de agravos e riscos e na atenção e recuperação das vítimas de violências e de acidentes". NUNES (1999) discutindo este artigo informa que ao tornar-se a violência objeto de saúde pública, entendida como - " a ciência e a arte de prevenir a doença, prolongando a vida e promovendo saúde através dos esforços organizacionais da sociedade" - o enfrentamento da violência acaba sendo o de atuar não somente sobre as conseqüências diretas dos atos de violência (medidas médicas de atendimento), mas juntar-se às propostas que conduzam à defesa da vida e da cidadania. Assim, os trabalhadores de saúde têm um papel importante, pois a eles cabem funções diretas no trato com pessoas, grupos e comunidades atingidas pela violência, não somente para minorar sofrimentos, mas para o exercício da vigilância epidemiológica para tempos de violência, comı também a denúncia de atos de violência.

CHESNAIS (1981) mostra que, na Europa, o desenvolvimento social, a educação formal, a melhoria da situação de vida da população trabalhadora, aliada à instituição da justiça, do exército e da polícia, foram os principais responsáveis pelo declínio da violência fatal.

Nos EUA o número os homicidios apresentaram taxas crescentes entre $1900 \mathrm{e}$ 1990, sendo assinalados como elementos fundamentais desta situação o culto às armas e o exacerbado preconceito racial. Sabe-se, todavia, que nesse país o número de óbitos nos acidentes de trânsito vem diminuindo nos últimos anos. BLINCOE (1996) mostra que, entre 1966 e 1994, houve queda do número bruto de óbitos por acidentes de trânsito, que de 50.894 passaram para 40.676 , numa população residente total que cresceu de 195 para 260 milhões de habitantes. Isso vem acontecendo pela implantação de programas de prevenção.

Desde 1914 naquele país vêm sendo desenvolvidos programas, politicas e pesquisas para prevenção das lesões em acidentes de trânsito. Naquele ano, baseado 
na crença de que acidentes de trânsito eram resultantes de má direção e erros humanos o recém-estabelecido Conselho Nacional de Segurança adotou abordagem simbolizada pelo slogan: "Os três E's: Engenharia, Educação e Fazer Cumprir as Leis (Enforcement)". A mais de 80 anos após este primeiro passo para a prevenção verifica-se e compreende-se melhor a atualidade da combinação dos elementos que constituem a estratégia dos três E's: legislação/fazer cumprir a lei; educação/mudança de comportamentos e engenharia/tecnologia, para redução dos grandes problemas resultantes em e dos acidentes. É fundamental aprender que as lesões de trânsito são resultados de processos complexos, uma mistura do vetor (máquina), suscetível (indivíduo), ambiente físico, prática social, história, atitudes individuais, desejos e comportamentos (NCIPC, 1989). Trata-se de problema que a análise e o planejamento podem, inclusive, ser beneficiadas com a utilização do modelo campo de saúde de Lalonde e Laframboise, modificado por Dever (DEVER, 1988) que leva em conta a "biologia humana, o ambiente, o sistema de organização de serviços de saude e o estilo de vida".

Em 1985, uma publicação do Comitee on Trauma Research (EUA), denominada Injury in America, documentou a magnitude do problema naquele pais. Esse trabalho levou ao Congresso Norte-Americano a estabelecer, junto com o governo federal, um centro para controle de lesões por causas externas. Esse serviço passou a trabalhar criando uma série de programas voltados ao combate às violências, considerando as causas externas de morbidade e mortalidade prioridades de saúde pública. Apesar de serem eventos que afetam toda a comunidade, os pobres são atingidos de forma desproporcional pois estão interligados às condições sociais, ambientais, econômicas desfavoráveis, contribuindo para o aumento das iniqüidades e desigualdades sociais. Os programas para sua prevenção necessitam estar atentos a estes problemas e se empenhar na busca de condições que revertam esta situação. Ações de base comunitária são fundamentais para o sucesso destes programas (NATIONAL COMITEE for INJURY PREVENTION and CONTROL, NCIPC, 1989).

Não há como não priorizar as violências em saúde pública. Qualquer piora em sua situação resulta em problemas de grande magnitude. Violência afeta a todos, quotidianamente, de forma súbita ou insidiosa, aparentemente ou não. Por serem 
eventos evitáveis, existem opções de técnicas e estratégias de prevenção, que podem ser desenvolvidas, visando-se o equacionamento do problema. Alguns dos pontos importantes para desenvolvimento destas ações implicam em:

a- integração de todas as áreas envolvidas na prevenção;

b- a prevenção das violências exige trabalho multidisciplinar, abrangendo profissionais de saúde pública, medicina clínica, legisladores, advogados, educadores, comunicadores, profissionais de saúde mental, mecânicos, cientistas sociais, engenharia do trânsito e muitos outros;

c- uma estratégia fundamental é a de estabelecer programas de prevenção de base comunitária. Neles. a população buscaria tanto recursos públicos como privados, visando compreender e equacionar os significantes problemas de saúde relacionados integrando os diversos setores da população;

d- é muito importante compreender as conseqüências das violências em saúde como parte de uma cadeia de causalidade em que um conjunto de eventos (elos) atuam no seu surgimento. Não é possivel que se aborde de forma separada cada elo e nem sempre é atuando sobre o mais forte ou sobre o mais óbvio componente desta corrente, que vamos resolver o problema e

e- em nenhum momento em que se trabalha buscando a prevenção e a redução dos problemas de causas externas de morbidade e mortalidade, em qualquer nível, podese desconsiderar as dimensões politicas de sua prevenção e controle (NCIPC,1989).

\subsection{Uma Abordagem Epidemiológica para Atuação Sobre as Violências e Acidentes Através dos Serviços de Saúde.}

Para que as violências possam ser equacionadas em seus aspectos ligados à saúde pública é altamente desejável a utilização da Epidemiologia.

A epidemiologia é ferramenta dos serviços de saúde. Como informa DEVER (1988), seus princípios e métodos podem ser aplicados a uma grande variedade de problemas. No campo da saúde, o autor destaca três usos principais para a epidemiologia: etiológico, clínico e administrativo. 
$\mathrm{Na}$ área do etiológico, a epidemiologia permite, a determinação de fatores de risco para as violências, isto é, calcular os riscos e chances de um individuo sofrer o evento e desenvolver agravos à sua saúde (DEVER,1988).

$\mathrm{Na}$ área clínica o conhecimento da prevalência, etiologia e prognóstico contribuem para um melhor manejo do pacientes individuais e de suas famílias.

$\mathrm{Na}$ área administrativa ela contribui para fazer o diagnóstico numa comunidade da natureza e distribuição dos eventos ligados à saúde e doença . Ela proporciona meios de monitorar a situação de saúde de uma população assim como projetar mudanças com o passar do tempo e em diferentes lugares. serve para a definição de prioridades, identificar indivíduos em risco (população-alvo). Fornece dados para planejamento, administração e avaliação de serviços de saúde (DEVER,1988). A principal ação da administração em saúde, segundo este autor, é "a tomada de decisões". A epidemiologia pode contribuir para que esta ação seja concretizada de forma adequada às necessidades de saúde de uma população.

Como fase inicial de uma abordagem apidemiológica das violências e acidentes a partir dos serviços de saúde é fundamental que se possa contar com informações confiáveis, o que não ocorre hoje no Brasil. É preciso que os dados de morbi-mortalidade advindos das situações originárias das causas externas, dos fatores e comportamentos que levam a riscos aumentados para as pessoas sejam levantados. Quais seriam as características ou circunstâncias, que levam determinados grupos de indivíduos a terem uma probabilidade de ocorrência de dano à saúde maior que a de outros? Quais desses fatores são identificáveis, observáveis, antes da ocorrência dos acidentes e violências? (CÉSAR, 1998).

Dentro desta perspectiva denominada "enfoque de risco" é possivel a previsão do aparecimento do dano (função preditiva); possivel controle ou eliminação destes fatores; e possível identificação de grupos de alto risco que devem ser objeto de atenção especial por parte do serviço de saúde. Para organização do serviço nesta perspectiva são propostas cinco etapas (CÉSAR, 1998):

a- diagnóstico de saúde: definição de fontes de informação adequadas, aprimoramento dos sistemas de informações disponíveis, registro continuo e adequado das informações, otimização de sistemas que incorporem informações 
de morbidade, pesquisas que utilizem a metodologia epidemiológica tanto para descrição da situação (descritivos: tempo, pessoa, lugar), como para sua análise (ensaios clínicos e comunitários) e descritivos (longitudinais: coortes, casocontrole e transversais);

b- identificação de fatores de risco, neste caso especifico, para violências, através de ações de vigilância epidemiológica padronizadas;

c- identificação dos indivíduos em risco, através de ações de controle padronizadas;

d- análise da adequação dos serviços de saúde como resposta às necessidades dos indivíduos (populações em risco), efetuando a partir destas análises as reformulações e adequações necessárias aos programas e serviços de saúde, para que atendam àquela(s) prioridade(s) e

e- criação de instrumentos para implantação, acompanhamento e avaliação das ações programadas e executadas, levando em o seu impacto na morbimortalidade da população, no surgimento do evento, bem como, no processo de trabalho do serviço de saúde.

Estas estratégias quando utilizadas com os cuidados preconizados por CESAR (1998) podem ser muito úteis no trabalho com violências.

SCARINGELLA (1999) destaca que na prevenção da violência existem questões vitais, entre elas a de que "a informação precisa ser tratada disponivel e atual. Ela é muito mais do que tabelas e estatísticas. Mais do que um mero banco de dados, deve ser ferramenta de operação dos agentes que intervêm no processo". Ela deve ser obtida de forma ágil e estar à disposição de todas as entidades envolvidas com o problema. "O Sistema de Vigilância Epidemiológica deve se integrar nacionalmente a uma rede de informação rápida e disponível. Assim, será possível a identificação dos fatores de risco e a partir daí gerenciá-los. Uma ação preventiva da violência é possível quando há monitoramento". 


\subsubsection{A vigilância epidemiológica e as causas externas de mortalidade e morbidade}

Pela relevância dos problemas oriundos de causas externas de morbidade e mortalidade para a saúde pública do Brasil é de grande importância que se trabalhe no sentido de sua prevenção e tratamento. A Politica Nacional para Redução da Morbimortalidade por Acidentes e Violència (BRASIL, 2001) tem entre suas diretrizes o monitoramento de acidentes e violências. Entre as suas propostas está a de melhorar informaçōes e monitorar a ocorrência desses eventos, através da criação de sistema de informação relativo a atendimento pré-hospitalar como também a otimização do sistema de informação de morbidade. Determina "o estabelecimento de ações padronizadas de vigilância epidemiológica para os casos de morbimortalidade de acidentes e violências determinando, inclusive, os fatores de risco (. . .)". O desenvolvimento de um programa de vigilância é um importante passo, apesar de não ser o único, para se buscar o equacionamento destes sérios agravos.

Vigiiância pode então ser definida como "a contínua, sistemática coleta, análise e interpretação de dados de saúde necessảrios para o desenho, implementação e avaliação de programas de saúde pública" (KLAUCKE e cols., 1988). A vigilância dos acidentes e violências, enquanto ação do setor saúde, pode trazer inestimáveis contribuições à prevenção, aos serviços de emergência, de tratamento e de reabilitação.

Com a promulgação da lei 8080, em 1990 instituindo o Sistema Único de Saúde (SUS) no Brasil (BRASIL,1998), foi oficializado o seguinte conceito para vigilância epidemiológica: "um conjunto de ações que proporciona o conhecimento, a deteç̧ão ou prevenção de qualquer mudança nos fatores determinantes e condicionantes de saúde individual e coletiva, com a finalidade de recomendar e adotar as medidas de prevenção e controle das doenças e agravos" (MINISTÉRIO DA SAÚDE (MS)/ FUNDAÇÃO NACIONAL DE SAÚDE(FNS), 1998). A orientação atual do Ministério da Saúde prioriza a construção e o fortalecimento de sistemas municipais de vigilância epidemiológica, dotados de autonomia técnicogerencial para enfocar os problemas de saúde próprios de suas respectivas áreas de abrangência. Assim sendo, espera-se até que, conforme as caracteristicas de cada 
realidade local, haja heterogeneidade do rol de agravos e doenças sob vigilância, preservando-se, é claro, aquelas de interesse nacional que mantêm a compulsoriedade da notificação. De acordo com o MS/FNS (1998) os propósitos e funções da vigilância epidemiológica são:

- coleta de dados;

- processamento de dados coletados;

- análise e interpretação dos dados processados;

- recomendação das medidas de controle apropriadas;

- promoção das ações de controle indicadas;

- avaliação da eficácia e efetividade das medidas adotadas;

- divulgação de informações pertinentes.

$\mathrm{Na}$ seleção de quais seriam os agravos e doenças priorizados pela vigilância epiç:iuslógica são definidos os seguintes critérios:

- magnitude - doenças com elevada freqüência, que afetam grandes contingentes populacionais, elevadas incidência. prevalência, mortalidade e anos potenciais de vida perdidos (APVP);

- potencial de disseminação - transmissibilidade da doença, colocando em risco o individuo e a comunidade;

- Transcendência - definida por três fatores:

$\checkmark$ severidade - medida pelas taxas de letalidade, hospitalizações, seqüelas;

$\checkmark$ relevância social - subjetivamente é o valor que a sociedade imputa ao agravo, através da estigmatização dos doentes, medo, indignação quando incide em determinadas classes sociais;

$\checkmark$ relevância econômica - aqueles que podem afetar 0 desenvolvimento de vido a restrições comerciais, perdas de vidas, absenteísmo ao trabalho, custo de diagnóstico e 
tratamento, entre outras;

- vulnerabilidade - possibilidade de prevenção e controle, permitindo a atuação concreta e efetiva dos serviços de saúde sobre indivíduos e coletividade;

- compromissos internacionais - esforços conjuntos para cumprimento de metas continentais e mundiais;

- regimento sanitário internacional - doenças de notificação compulsória internacional;

- epidemias, surtos e agravos inusitados

As fontes de dados a serem trabalhadas são aquelas já citadas, no estudo do Comitè Técnico Científico (CTC) do Ministério da Saúde (MINAYO \& SOUZA, 1999). Outras possibilidades de levantamentos de informações são através de Estudos Epidemiológicos (inquéritos e levantamentos), Sistemas Sentinelas (mortes prematuras, incapacidac e c voenças desnecessárias).

O sistema deve estar preparado para obter diagnósticos confiáveis dos casos utilizando para tal roteiro de investigação, definindo rotinas que prevejam o andamento da investigação, busca ativa de casos, busca de pistas. Os dados obtidos deverão ser consolidados, processados e analisados de acordo com as técnicas da bioestatística.

A vigilância epidemiológica de causas externas deve apresentar as características: a- ser simples; b- ser contínua (aspecto que a diferencia da pesquisa); c - ter obrigatoriamente três componentes: a informação, a análise regular da informação com fundamento no conhecimento científico e a ampla disseminação da informação analisada a todos que dela necessitarem (WALDMAN \& MELLO JORGE, 1999). É um instrumento ágil e de baixo custo que deve ser aplicado ao constante aperfeiçoamento técnico dos serviços de saúde.

WALDMAN \& MELLO JORGE (1999) e KLAUCKE (1988) mostram que a operacionalização de um sistema de vigilância para um específico efeito adverso à saúde implica a avaliação de sua relevância, na clara delimitação de seus objetivos e na definição de caso perfeitamente adequada. Após esta fase se identificam os 
componentes do sistema:

- população alvo,

- periodicidade da coleta de informações,

- tipo de informações que serão coletadas,

- fonte dessas informações, quem provè essas informações para o sistema,

- como a informação será coletada,

- como é transferida a informação,

- quem analisa as informações,

- como são analisadas as informações,

- freqüência desta análise,

- freqüência da difusão de relatórios,

- instrumentos de difusão.

Essa vigilância segundo WALDMAN \& MELLO JORGE (1999) deve ter por objetivo fornecer os seguintes subsidios para a elaboração de programas de prevenção e controle: estimar a morbi-mortalidade em termos de magnitude; tendências custos e impacto social; identificar grupos e fatores de risco; detectar clusters; avaliar a efetividade de intervenções; induzir pesquisas e incorporar novos conhecimentos. Deve também contribuir para o aprimoramento dos cuidados médicos na fase aguda, no tratamento e na reabilitação dos atingidos.

Local privilegiado para a coleta de informações sobre acidentes e violências os serviços de pronto-socorro muitas vezes não são considerados passíveis destes tipos de ações. Trata-se de setor em que o potencial em gerar informações de extrema utilidade para o setor saúde é totalmente negligenciado no Brasil. Literalmente descarta-se uma ferramenta fundamental para a tentativa de elevação da qualidade de vida e de saúde. DESLANDES (1999) informa que "em nenhum outro serviço de saúde a violência adquire tamanha visibilidade como na emergência. Esse serviço é para maioria das vítimas a 'porta de entrada' no sistema público de saúde". Na 
maioria das vezes trata-se do único lugar em que uma pessoa vítima de violência estará em contato com um profissional de saúde, sendo também, muitas vezes, o único momento em que a violência é declarada. Uma outra razão para que o prontosocorro seja considerado de fundamental importância como fonte de dados para a prevenção é que a "maioria dos casos de violência reincidirá (com igual ou superior gravidade) se não houver ação que interrompa sua dinâmica. Esse raciocínio encontra farto respaldo em pesquisas sobre violências doméstica contra crianças, violência doméstica contra mulheres e nos casos de tentativas de suicidio."

\subsubsection{Sistemas de vigilância de lesões}

Sistemas de vigilância epidemiológica a causas externas de morbidade e mortalidade são pouco estudados no Brasil. No entanto, existem, em outros paises, agencias privadas e governamentais que continua ou periodicamente coletam dados, procedem sua análise, medem tendências, detectam áreas de risco e identificam fatores relacionados com estes agravos. ROBERTSON (1992) identificou alguns destes sistemas, apontando suas vantagens e desvantagens, e sugeriu aperfeiçoamentos para que tivessem utilidade no controle destes problemas de saúde, particularmente numa vigilância voltada à prevenção em nivel local. Para tal foram utilizados critérios tais como: relevância para saúde pública, custo-beneficio, aceitabilidade pelas pessoas que elaboram os registros de dados, divulgação rápida e atualizada das informações, relevância dos eventos notificados para a saúde da população estudada, sensibilidade (definida como a capacidade de identificação de todos os casos), especificidade (capacidade de identificação dos não-casos), simplicidade da coleta e possibilidade e flexibilidade em incluir novos problemas não incluídos originalmente.

\section{- Vigilância Geral}

Como fonte geral de dados de mortalidade ROBERTSON (1992) cita as declarações de óbito e para o caso de vítimas não-fatais registros hospitalares. As vantagens e desvantagens apontadas para essas fontes de dados são as mesmas já apontadas em outra parte deste trabalho (dificuldades de informação avaliadas no item 1.3). 


\section{- Sistemas Especiais de Vigilância}

ROBERTSON (1992) mostra alguns sistemas de vigilância especificos para monitoramento de determinados tipos de causas externas, que justificam a manutenção de sistemas especiais de vigilância:

a- De acidentes por veículos a motor - $\mathrm{O}$ autor considera que o melhor sistema de vigilância de acidentes em termos de existência de dados detalhados das circunstâncias dos acidentes e do seu ambiente de ocorrência nos Estados Unidos da América (EUA) é o Fatal Accident Reporting Sistem (FARS) da National Highway Traffic Safety Administration (NHTSA) que iniciou suas atividades em 1975. Esse sistema coleta dados de todos os acidentes envolvendo veículo a motor ocorridos nas rodovias públicas dos EUA para todos os casos em que o individuo acidentado morre no decorrer de trinta dias. A maioria das informações se origina de registros policiais complementados por agencias de licenciamento de veículos, hospitais, registros de investigações médicas ou de mortes suspeitas através de policiais. Dados informatizados sic fornecidos pela própria NHTSA ou pelo Instituto de Pesquisas em Transportes da Universidade de Michigan. Entre outras, fornecem informações sobre concentração de álcool no sangue das vítimas e características dos veículos, codificadas a partir do número de sua placa de identificação. Outro sistema com dados semelhantes ao FARS, com a diferença de ter seus dados coletados em amostras aleatórias colhidas em regiões de ocorrência de acidentes de trânsito, relatados pela polícia é o National Accident Sampling System (SASS). Seus dados, relativos ao número de lesões ocorridas, geralmente estão subestimados pois nem todas os traumatismos causadas por acidentes são detectadas pela polícia. É vantajoso em relação ao FARS por um maior detalhamento das lesões tais como a área anatômica, escores abreviados do trauma e de sua severidade. É útil para a realização de estudos analiticos e de tendências de casos não-fatais.

b- De violências e homicídios - Para os EUA, no caso de óbitos, são comparados dados provenientes de registros policiais locais e federais e de certificados de óbito. Para vítimas não-fatais existem pesquisas domiciliares de âmbito nacional que são os National Crime Surveys. Entretanto, apresenta dados inadequados para determinação da natureza, características e severidade das lesões. As informações são apresentados 
de forma complexa, a técnica da amostragem é complicada, exigindo certa familiaridade de quem os pesquisa. Nos EUA (ROBERTSON, 1992) a melhor forma de pesquisa de informações a respeito de lesões não-fatais, ocasionadas por violências, em nível local, é através de registros hospitalares, apesar de serem geralmente subestimados pois muitas vezes são relatados como quedas ou acidentes com armas de fogo.

c- De tentativas e dos óbitos por suicidios - A vigilância da mortalidade por suicídios é feita a partir de certificados de óbito. Trata-se de informação muitas vezes duvidosa pois, em diversas circunstâncias, existem dificuldades em se determinar a intencionalidade do evento. Em outras ocasiões, ocorre a omissão da causa básica, para atender a pressões familiares. Esses fatores levam a informações subestimadas em relação à quantidade de mortes que ocorrem devido a suicídios. Pelas mesmas razões, as tentativas não-fatais são inúmeras vezes subnotificadas e identificadas como "acidentes".

d- De lesões ocupacionais, por incênciuss, por acidentes de barco e relativos ao consumidor - As lesões ocupacionais são avaliadas por inquéritos anuais conduzidos pelo Bureau for Labor Statistics (BLS) que desvolve um inquérito anual. Entretanto em alguns casos existem evidências tanto de subnotificação como de supernotificação dependendo da importância pecuniária estabelecida por cada estado norte-americano em relação aos diversos tipos de lesão. Nos casos provenientes de incêndios são utilizados os registros do National Fire Data Center e para acidentes náuticos os da Guarda Costeira.

Quanto a lesões relacionadas com o consumidor, a US Consumer Products Safety Comission (CPSC) trabalhou com amostra de pronto-socorros de hospitais estatisticamente representativa dos estabelecimentos prestadores atendimentos a emergência norte-americanos e declarações de óbito ROBERTSON., 1992). As informações provenientes da citada amostragem é disponibilizada no banco de dados denominado National Electronic Injury Surveillance System (NEISS), que a partir de julho de 2000 expandiu sua coleta de informações a todos os tipos e causas externas de lesões não-fatais e envenenamentos tratados em departamentos de emergência dos hospitais dos EUA (CPSC, 2001 in http://www.cpsc.gov/about/clrnghse.html), tendo 
este sistema ampliado recebido o nome de NEISS All Injury Program (NEISS-AIP) que é fruto da colaboração do CPSC com o National Center for Injury Prevention and Control, que faz parte dos Centers for Diseases Control (MMWR, 2001). Essa nova base de dados é importante no sentido de se agrupar as lesões não-fatais em um único sistema, até agora considerado de forma separada.

\section{- Vigilância de Fatores de Risco}

Nos EUA são conduzidos periodicamente pelo CDC inquéritos telefônicos, em numerosos estados, que buscam efetuar a medida de fatores de risco relacionados com variadas formas de comportamento com tabagismo, alcoolismo, uso de cintos de segurança, etc. (ROBERTSON, 1992).

\section{- Vigilância Orientada para a Prevenção}

Para sucesso de programas de prevenção e controle de lesões oriundas de causas externas a partir de atividades de vigilância deve-se incluir as seguintes etapas:

a) vigilância da incidência e severidade das lesões com o objeti locais e populações submetidas a altas taxas destes eventos e a fatores que aumentem seu risco;

b) identificação de estratégias para redução do risco;

c) implementação destas estratégias nas populações identificadas e

d) contínua vigilância para monitoramento das tendências estes fatores e agravos.

Como exemplo de vigilância, com a adequação da obtenção de informações às necessidades de prevenção, pode ser visto no sistema de coleta de dados desenvolvido para o Indian Health Service - IHS (ROBERTSON, 1992). Desenvolveram-se instrumentos que notificavam lesões provenientes de acidentes por veículo a motor; incêndios, queimaduras ou fumaça; queda; agressões interpessoais; afogamentos; tentativas de suicídio e outras. Os formulários incluíam não apenas as circunstâncias dos eventos como também listas de possíveis ações para sua prevenção e/ou redução de sua severidade. Após sua implantação este sistema logrou alguns resultados exitosos na redução da incidência de lesões e óbitos por causas externas em algumas populações nativas dos EUA (ROBERTSON, 1992) . 


\subsection{Relevância do Tema, Limitaçōes e Finalidades do Estudo}

Os estudos e indicadores discutidos nesta "Introdução" demonstram que as causas externas ocasionam alta incidência de problemas de saúde, inclusive sendo responsável por uma considerável parcela dos óbitos da população e por gastos extremamente elevados do Sistema de Saúde. O melhor conhecimento de suas características, bem como dos fatores que ampliam o risco ou que protegem de suas consequiências mórbidas é importante para que ações de prevenção e recuperação da saúde sejam planejadas e implementadas. Para tanto, é importante que seja estruturado um Sistema de Informações que contemple todas as probabilidades envolvidas na gênese e ocorrência das causas externas.

Existem diversas etapas, em vários niveis de complexidade, a serem abordadas entre a geração e a utilização da informação. A seleção do que é relevante desde o conhecimento de hábitos, crença, usos e costumes da população que tenham relação com o tema até a exata determinação das causas do óbito. Isso passando por todas as etapas do atendimento desde o pré-hospitalar até o desenlace do processo, com alta, alta mais seqüela ou morte. Trata-se de um amplo universo a ser estudado, de grande diversidade e complexidade. Este trabalho procura, dentro de suas limitações de recursos, trazer uma pequena contribuição ao tema efetuando uma discussão daquilo que ocorre em relação aos atendidos em serviços de urgência e emergência, buscando estruturar e testar uma proposta de ficha de notificação e fazendo um estudo preliminar de seu fluxo. Busca-se acrescentar pontos que possam abrir a possibilidade de ampliar os conhecimentos e trazer indagações que contribuam para o desenvolvimento de novos estudos nesta área. 


\section{2- OBJETIVOS}

Este trabalho tem como objetivos:

- construir e testar ficha de notificação de causas externas de morbidade e mortalidade para ser utilizada em setor de atendimento às urgências e emergências (pronto-socorro/ pronto-atendimento) e que possa servir como subsídio para um futuro sistema de informação destes agravos;

- testar o fluxo deste instrumento em serviços de saúde em nível municipal;

- estudar, a partir da coleta de informações, variáveis relacionadas às vitimas e às circunstâncias destes agravos e lesões e as suas possiveis associações. 


\section{3- MATERIAL E MÉTODOS}

Este trabalho foi realizado com vítimas de causas externas de lesão, no municipio de Pouso Alegre, MG e que foram atendidos entre fevereiro e junho de 2003, num serviço de pronto-atendimento municipal Pouso Alegre situa-se na região sul do Estado de Minas Gerais, com população de 106.776 habitantes (IBGE, 2002). É um pólo industrial e multisetorizado. Ali convivem empresas multinacionais $\mathrm{e}$ brasileiras de grande porte com inúmeras outras pequenas e médias indústrias, dos diversos segmentos. A economia municipal se estrutura à base de 700 unidades industriais, 1.500 unidades agropecuárias e mais de 4.000 unidades comerciais e de serviço (anexo 3).

Foi um estudo transversal, descritivo, com dois componentes. Um primeiro para testar um instrumento de coleta de dados que objetiva trazer informações que permitam um aprofundamento do conhecimento da realidade que envolve as violências e os acidentes. Além disso, que também traga informações úteis para a melhoria do atendimento, do planejamento e da elaboração. implantação e avaliação de ações e políticas de saúde necessárias para o enfrentamento deste importante problema de saúde pública. O segundo componente é o que levanta a partir da operacionalização deste instrumento, informações sobre vítimas e circunstâncias da ocorrência das causas externas, a partir de dados gerados tendo como origem um serviço que normalmente é o que presta o primeiro atendimento a este tipo de paciente, uma vez que, a prática de atenção pré-hospitalar ainda é pouco generalizada e é destinada àquelas vitimas de situações em que haja uma gravidade expressiva. Nesta perspectiva, muitas lesões que normalmente não são detectadas e conhecidas pelos estudos desta área, as de baixa gravidade passam a ser descritas e conhecidas.

\subsection{A Ficha para Coleta de Dados}

Para se realizar o presente estudo, inicialmente buscou-se estabelecer a maneira adequada de se elaborar uma ficha epidemiológica de coleta de dados sobre problemas de saúde ocasionados por causas externas, ou seja, o instrumento de trabalho. Para tanto, o ponto de partida foi um levantamento bibliográfico inicial, a partir de onde, foram selecionadas algumas variáveis de interesse para um futuro sistema de informações sobre estas causas morbidade e mortalidade em serviços de 
urgência e/ou emergências, que pudessem ser úteis desde para práticas cotidianas dos serviços de saúde e até para propostas de estabelecimento de políticas e planejamento para combate às conseqüências destes agravos (ROBERTSON,1992; CONCHAEASTMAN \& VILLAVECES, 2001; MINISTÉRIO DA SAÚDE; FUNDAÇÃO NACIONAL DE SAÚDE; CENTRO NACIONAL DE EPIDEMIOLOGIA, 2002, MELLO JORGE, 1997b; MESQUITA FILHO, 1998; CDC,1997; BRASIL, 2001; AAAM, 1990; ANNEST, CONN \& JAMES, 1996, THORNTON e cols., 2000). Ao mesmo tempo, trabalhou-se com a preocupação de que este instrumento deveria ter a possibilidade de ser preenchido num espaço de tempo curto, compatível com a natural urgência dos procedimentos destes serviços. Buscou-se, por isso, um questionário que tivesse como características a objetividade, a simplicidade de preenchimento, além de dever ser de fácil compreensão para o encarregado de seu preenchimento. A partir deste estudo, buscando-se adequar o que foi encontrado às condições da realidade brasileira, foi elaborada uma primeira proposta para 0 desenho da ficha para coleta de informações. GRAITCER (1992) e SALTZMAN \& IKEDA (1998) fizeram uma lista de variáveis que devem ser utilizadas na informação sobre causas externas, e que uma vez escolhidas por poderem prover alguns dados essenciais minimos e que são as seguintes:

- Pessoa: idade, sexo, raça e local de residência da vítima. Se se tratar de lesão ocasionada intencionalmente coletar os mesmos dados do agressor;

- Localização: determinar onde se deu a ocorrência do problema (escola, casa, trabalho, etc.;

- Natureza: identificar o local do corpo lesado;

- Causa: acidente, violência, envenenamento, auto agressão, etc.:

- Diagnóstico: tipo de lesão causada;

- Conseqüência: óbito, hospitalização, incapacidade temporária ou permanente, encaminhamento a pronto-socorro, alta e

- Outros fatores por exemplo: uso de capacetes e/ou cinto de segurança, uso de álcool ou drogas, etc.;

- Hora e dia da semana da ocorrência.

A partir do levantamento bibliográfico foi elaborada uma primeira proposta de ficha de coleta de dados. Após esse primeiro passo, a proposta inicial de 
formulário foi exaustivamente discutida tanto com profissionais da área de epidemiologia. bem como com profissionais com prática na área das urgências para coleta de críticas e de sugestões para melhor adequação às suas finalidades (validade de face, ABRAMSON, 1994).

A ficha de notificação (anexo 1) é constituída em sua maior parte de questões fechadas, mas apresentando algumas abertas. É subdividida em quatro partes; na primeira (item I) são coletados dados pessoais da pessoa que foi vítima da violência ou do acidente (número do cartão SUS, nome, endereço com rua, número e bairro, código de endereçamento postal, telefone, cidade, idade, sexo, estado civil, profissão). Em seguida é coletada a data e a hora de entrada do paciente no serviço. Em seguida inicia-se a segunda parte da ficha visando que se estabeleça a causa do evento (item II, questões de 1 a 7). Ai, foram utilizados os critérios de classificação da CID- 10 (1995), capitulo XX, para causas externas de morbidade e mortalidade. Para facilidade de posterior codificação, a ordem adotada para apresentação dos tópicos na ficha foi a mesma adotada pela CID- 10, incluidos os seguintes grupamentos:

- V01 a V99 - Acidentes de transporte;

- W00 a X59 - Outras causas externas de lesões acidentais;

- X60 a X84 - Lesões autoprovocadas voluntariamente;

- X85 a Y09 - Agressões;

- Y10 a Y34 - Eventos (fatos) cuja intenção é indeterminada;

- Y35 a Y36 - Intervenções legais e operações de guerra;

- Y40 a Y84 - Complicações de assistência médica e cirúrgica;

- Y85 a Y89 - Sequielas de causas externas de mortalidade e morbidade;

- Y90 a Y98 - Fatores suplementares relacionados com as causas de morbidade e mortalidade classificadas em outra parte.

É importante assinalar que toda vez que a opção "outros" aparece ela surge seguida, imediatamente da indagação "quais ou qual" para ser preenchida de forma aberta. Na digitação destes dados não se utilizou a codificação da CID e sim a numeração da própria ficha. Em seguida, existe, no instrumento, espaço para descrição do evento de maneira aberta. Após este momento, a partir do detalhamento de suas 
circunstâncias, se efetua com maior precisão a codificação utilizando a CID-10. O item III informa o procedimento tomado com o paciente: nenhum, orientação, prescrição, limpeza e curativo, sutura, imobilização e outro. No item IV é estabelecido o local e o momento da ocorrência, utilizando-se, também, para o local, os critérios da CID: residência, escolas, áreas para prática de esportes, rua, estrada, áreas de comércio e serviço, áreas industriais e em construção, zona rural e outro. Logo após, abre-se espaço para anotação da data e horário do evento, e ainda, questão aberta buscando-se o endereço (rua e bairro do local da ocorrência). Em seguida, o item $\mathrm{V}$, coleta dados sobre a forma com que a vítima chegou ao serviço (a pé, trazido pela polícia, por ambulância, transporte particular, ônibus, táxi, outro) o de número VI destino (alta, internação, encaminhamento, óbito, ignorado) e o tempo de permanência no serviço. Finalmente, a última parte da ficha de notificação (item VII) define-se qual a lesão que ocorreu e sua localização. Para padronização das lesões novamente foram utilizados os critérios da CID-10 (1995), capítulo XIX. Para descrição das mesmas, também se trabalhou com o Dicionário Médico Stedman (1994). Trabalhou-se com a seguinte classificação: traumatismo superficial, ferimento; luxação, entorse, distensão; traumatismos dos nervos e medula espinhal; traumatismo dos vasos sangüineos; traumatismo dos tendões e músculos; traumatismo dos órgãos internos; lesões por esmagamento; corpo estranho; queimaduras; fraturas; intoxicações.

Para que não surjam dúvidas quanto à classificação das lesões é necessário que se tenha a padronização de cada um de seus tipos, pois o comportamento dos entrevistadores deve ser uniforme, sem que cada um siga critérios próprios de classificação. Foi também utilizado o Stedman Dicionário Médico 25. ${ }^{a}$ edição de 1996, escrito originalmente por Thomas Lathrop Stedman, para se chegar a esta padronização complementar à CID-10, utilizando-se as definições constantes do Manual de Instruções par Preenchimento (anexo 4)

Quanto à definição da topografia das lesões optou-se por não se detalhar com profundidade na anatomia da vítima a sede do agravo (anexo 4). Foram considerados oito grandes segmentos para detecção das diferentes lesões (cabeça, pescoço, tórax, abdome, dorso, pelve, membros superiores, membros inferiores). Para as fraturas, pelo fato delas dizerem respeito a estruturas ósseas utilizou-se outras definições 
anatômicas: crânio e ossos da face, pescoço, tórax, coluna torácica, coluna dorsal, pelve, bacia, membro superior e membro inferior. Nas intoxicações não se faz necessário que se tipifique a localização. Uma vez preenchida a ficha ela era assinada pelo profissional encarregado da coleta de informações.

\subsection{Seleção e Preparo do Pessoal para Coleta de Dados}

Foram selecionadas cinco enfermeiros plantonistas do serviço de prontoatendimento. A seleção de pessoal já ligado ao serviço se deveu ao fato de que se buscava a maior proximidade possivel do funcionamento real de um sistema de informações em implantação. A escolha recaiu no profissional de enfermagem pela necessidade de pessoal qualificado para interpretar e fornecer a informação precisa. Em seguida a equipe foi submetida a treinamento composto por seis horas de discussão teórica e prática. Nesse treinamento os profissionais conheceram o projeto de pesquisa, tomaram contato com a ficha de notificação e treinaram, inicialmente entrevistando uns aos outros vindo a seguir o preenchimento de campo, sob orientação do responsável pela pesquisa. Foram discutidas uma a uma as perguntas constantes do instrumento e a forma padronizada de preenchimento dos dados e da abordagem ao paciente. Houve uma grande preocupação com a homogeneização das condutas individuais dos entrevistadores, no sentido de se evitar vieses derivados de um preenchimemto heterogêneo das fichas e de registro de dados que sofressem influências das visões pessoais dos pesquisadores Após o encerramento desta primeira etapa do treinamento, iniciou-se uma segunda com a realização de estudo piloto.

\subsection{A Definição de Caso e Critérios de Inclusão e de Exclusão}

Conforme é preconizado por WALDMAN E MELLO JORGE (1999) "quando se necessita definir caso, para um particular sistema de vigilância, deve-se decidir em função de seu objetivo". HOLDER e cols (2001) exemplificam esta asserção com os seguintes exemplos:

- $\quad$ se o objetivo é o de monitorar a capacidade de prestação de cuidados em um determinado serviço, então "um caso" vai ser qualquer visita (primeira ou subseqüente) a este serviço de uma pessoa portadora de agravo devido a 
causas externas ou por um suspeito de ter sido afetado por este tipo de problema;

- se o objetivo for o de monitorar a incidência de diferentes tipos de agravos ocasionados pelas causas externas, então "um caso" será a conseqüència daquele evento quando se apresentar pela primeira vez ao serviço. Visitas subseqüentes para a mesma lesão não são contadas. Se uma pessoa apresentar lesões múltiplas deverá ter cada uma delas registrada em separado com se fossem casos diferentes, mesmo que tenham ocorrido em um mesmo evento;

- já se o objetivo for monitorar a incidência de pessoas lesadas por causas externas, então "um caso" será registrado na primeira visita da pessoa ao serviço, independentemente do fato deste paciente apresentar uma ou mais lesões. Retornos desta pessoa ou pacientes não-lesados não serão contados como casos.

Como WALDMAN E MELLO JORGE (1999) assinalaram, "existe um amplo espectro de agravos rotulados genericamente como causas externas". Desta maneira, a delimitação da população de estudo se relacionou ao fato ou fator que induziu ao acidente ou violência, delimitando-se ainda o nível de assistência médica em que os casos foram atendidos, ou seja, o serviço de atendimento a urgència $e$ emergência. $\dot{E}$ importante que se acrescente que estão incluídos no estudo os individuos que apresentem as características supracitadas, independentes do grau de gravidade de seus agravos. Neste trabalho, também foi critério para definição do caso que apenas aquelas vitimas de acidentes ou de violências que se apresentaram em primeira consulta seriam consideradas, descartando-se os retornos pelo mesmo problema. Se o mesmo paciente novamente se envolvesse em outro agravo da mesma natureza ou de natureza semelhante, aí então, novamente, seria alvo de notificação.

Foram incluídos todos os pacientes que procurassem ou fossem levados ao serviço municipal de pronto-atendimento com problemas de saúde causados por ocorrências e circunstâncias ambientais conforme classificação efetuada pela CID 10 (1995) em seu capitulo XX de V01 até Y98: causas externas de morbidade e mortalidade e que fossem residentes no município de Pouso Alegre. Foram excluidas 
as pessoas que lá estiveram por outros motivos ou por razões não-determinadas e ainda aquelas que residissem em outras cidades.

Foram estudados neste trabalho 380 pacientes que procuraram o prontoatendimento municipal, que puderam ser definidos como individuos portadores de morbidade decorrente de causas externas, e ainda, se enquadraram nos critérios de inclusão definidos para este estudo.

\subsection{O Estudo Piloto}

O estudo piloto foi o primeiro contato direto com a população em estudo. Funcionou como "um ensaio preparatório da investigação" (SCHLESSELMAN, 1982; ABRAMSON, 1990). Os objetivos de sua realização foram testar o ficha e verificar sua exequibibilidade prática, treinar a equipe de entrevistadores, verificar as necessidades de mudanças e acertos de "última hora" que pudessem surgir por imprevistos não imaginados durante o planejamento da pesquisa e para se ter uma idéia do que pudesse ser encontrado.

Durante seis dias do mês de fevereiro de 2003, a equipe treinada preencheu no serviço de pronto-atendimento municipal a ficha de notificação de causas externas.

Os entrevistadores, ao se encaminharem para o serviço, portavam um crachá que os identificava como enfermeiro, além de traje de cor branca, o que, na maioria vezes, foi útil para vencer resistências dos entrevistados.

Foi selecionado para realização do estudo piloto a unidade de prontoatendimento municipal da cidade de Pouso Alegre, MG. A população eleita para a coleta de dados se constituiu daqueles pacientes que procuraram o citado serviço que funciona em regime de plantão de vinte e quatro horas, durante toda a semana devido a problemas relacionados com causas externas de morbidade e mortalidade entre 21 e 27 de fevereiro de 2003. No período foram preenchidos os vinte e cinco formulários que foram utilizados no estudo piloto. As principais propostas deste estudo (anexo 2) foram:

- modificação do layout da ficha de coleta de dados através do aperfeiçoamento de seu desenho inclusive com a colocação de algumas questões numa nova ordem e introdução de alguns tópicos novos; 
- introdução de tópicos descritivos da causa externa e do agravo atendido;

- ampliação do número de opções constantes do item "outras lesões acidentais" que se encontrava incompleto e sem preencher as necessidades de informação;

- introdução de campos para descrição da lesão e da sua causa externa na busca de uma maior acurácia do dado coletado e da ampliação de seu valor preditivo positivo;

- a introdução destes novos campos pode ter a conseqüência de ampliar a validade de conteúdo do instrumento;

- efetuar a definição de padrão-ouro, que por exemplo poderá ser o preenchimento do mesmo instrumento concomitantemente por um especialista, a partir do qual poder-se-á chegar aos valores de especificidade, sensibilidade, valores preditivos positivo e negativo;

- suspender o item destinado a se determinar a avaliação da gravidade do evento por não se dispor de escala que se prestasse à aplicação em ambiultie de prontosocorro. Utilizar como alternativa a escala de Glasgow (JENNET e cols., 1974; TEASDALE \& JENNET, 1974; TEASDALE \& JENNET, 1976) e combiná-la com medidas indiretas tais como tipo da lesão, destino do paciente, procedimento tomado;

- redesenho das entradas para o banco de dados para que se permita uma análise adequada quando se for trabalhar com amostras maiores;

- assegurar a validade externa deste instrumento trabalhando-se com todo o universo de usuários do serviço de urgência e emergência;

- ajustar o fluxo proposto para as informações.

$\mathrm{O}$ estudo piloto não registrou qualquer recusa por parte dos pacientes $\mathrm{e}$ familiares entrevistados. Pacientes que afirmaram ter ido ao serviço com outra finalidade que não o atendimento por acidentes e violências foram excluídos. Os resultados e dados coletados no estudo piloto não foram incluídos no trabalho definitivo, que coletou novos dados. 


\subsection{O Fluxo das Informações}

A produção de informações sem a determinação do seu fluxo pode levar a uma situação que resulte na sua perda. Para tanto é fundamental viabilizar um fluxo ágil e simples para que os dados coletados cumpram seus objetivos. Nas situações mórbidas originárias de causas externas na grande maioria das vezes a procura do caso pelo serviço de saúde é imediata, a não ser nas situações de problemas extremamente leves. A informação então deverá obedecer um fluxo como o concebido e apresentado na figura 5 :

- após a ocorrência do evento o paciente ou recebe atendimento préhospitalar e é encaminhado a um serviço de urgência/emergência ou;

- após a ocorrência do evento o paciente é diretamente encaminhado ao serviço ou ;

- após a ocorrência do evento o paciente encaminha-se espontaneamente para o atendimento;

- lá chegando recebe atendimento e tem sua ficha preenchida pela equipe de enfermagem do servico, no momento do atendimento. O próprio paciente, ou acompanhante é o responsável pelo fornecimento das informações;

- a ficha é conferida pelo supervisor do serviço e encaminhada à secretaria municipal de saúde (SMS);

- SMS reconfere a ficha, verifica se há inconsistências, omissão de informações, erros:

- em caso positivo a ficha é devolvida para a origem para as devidas correções;

- em caso negativo ficha é lançada no banco de dados;

- é feita a análise e a interpretação dos dados e das estatísticas obtidos;

- divulgação de resultados;

- encaminhamento dos resultados para consolidação e divulgação estadual;

- encaminhamento para Ministério da Saúde pela Secretaria Estadual, para consolidação e divulgação nacionais.

O fluxo estabelecido foi testado a partir da procura ou do encaminhamento ao serviço por parte do portador de problemas ocasionados pelas causas externas. Uma vez definido o caso, através dos critérios de inclusão pré-estabelecidos, passava-se ao 
preenchimento do formulário, que dependendo da gravidade do caso, poderia ser preenchido antes durante ou após o atendimento. Procurou-se trabalhar o processo descrito com uma agilidade suficiente para que o atendimento da pessoa não fosse prejudicado e que se garantisse a qualidade da coleta de dados. Esta foi uma importante preocupação pois se trata de um ponto de estrangulamento para 0 funcionamento desta proposta. Nos momentos de pico de movimento a coleta era feita assim que um dos responsáveis estivesse disponivel, sempre se priorizando o atendimento para depois se efetuar o preenchimento da ficha.

$\dot{E}$ importante ressaltar, que as etapas em nível estadual e nacional do fluxo de informações não foram testadas, pois a abrangência deste estudo é municipal. Tratase de sugestões que poderão ser estudadas a posteriori. 
Figura 5: Fluxo das informações de notificação de causas externas em serviços de urgência e emergência

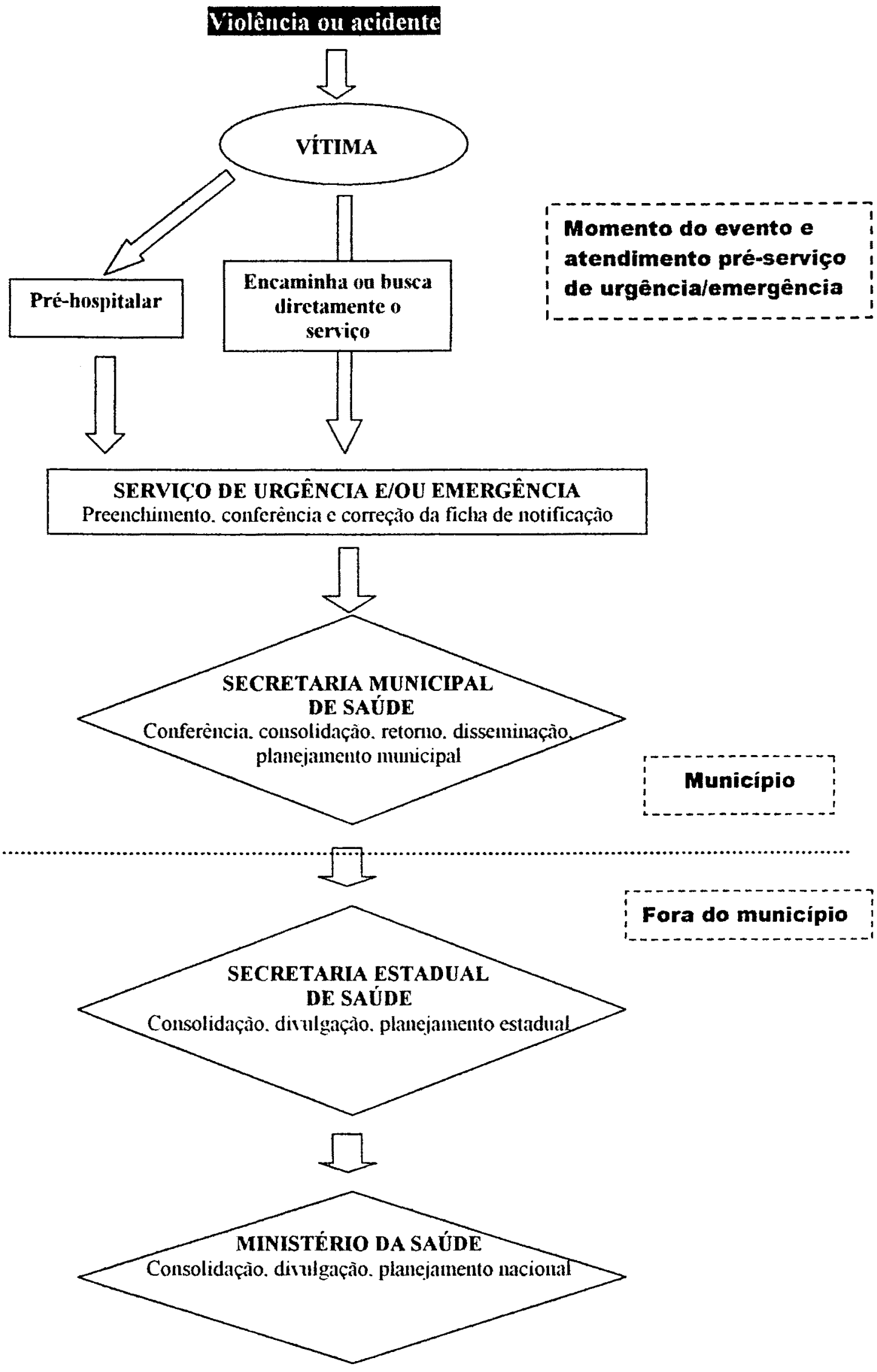




\subsection{Local da Pesquisa}

O local selecionado para a pesquisa foi o serviço de pronto-atendimento municipal da Prefeitura da cidade de Pouso Alegre, situada no sul do estado de Minas Gerais. A proposta inicial do trabalho era que a coleta de dados acontecesse neste serviço e no pronto-socorro do hospital de clínicas da universidade local. Este serviço, até o início do mês de janeiro de 2003, era o único que prestava atendimentos de urgência e emergência para o municipio e para algumas outras cidades da região. Entretanto, a partir daquele mês, por decisão administrativa interna, passou a atender apenas emergências, entendendo por isto agravos que necessitassem de atenção imediata, com cobertura hospitalar (clínica e cirúrgica) e de terapia intensiva. Os serviços citados são cobertos pelo Sistema de Informações Hospitalares do SUS (SIH/SUS) e no caso da ocorrència de óbitos pelo Sistema de Informações sobre Mortalidade (SIM). Outra dificuldade encontrada para o trabalho junto ao pronto-socorro universitário foi que no periodo de março a abril de 2003 suas atividades foram parcialmente paralisadas, devido a uma greve, por parte dos médicos que lá atendiam. Diante disto optou-se em se trabalhar com serviço ainda não coberto por qualquer tipo sistematizado de coleta de dados, cujas informações não se encontram disponibilizadas, ou seja, aquele que presta o primeiro atendimento. Os dados colhidos no pronto-atendimento são oriundos de indivíduos atendidos devido a necessidades urgentes ou emergentes causadas pelas causas externas, desde as mais leves até as que necessitaram encaminhamento para atendimento hospitalar clínico ou cirúrgico.

\subsection{A Coleta de Dados}

Os profissionais treinados para a coleta dos dados eram também plantonistas do pronto-atendimento. As informações eram prestadas pelas próprias vítimas das causas externas e no caso de algum impedimento por seu acompanhante. Antes de se iniciar o preenchimento da ficha, explicava-se ao paciente a razão daquela coleta e pedia-se autorização o seu procedimento, informando-se ainda que os dados eram de caráter confidencial e que deveriam ser usados para trabalho científico, não estando autorizada a divulgação de quaisquer informações que pudessem colocar a privacidade do entrevistado em risco. Todos os pacientes manifestaram sua 
concordância em participar das entrevistas, não tendo sido registrada nenhuma recusa, mesmo em alguns que se apresentaram notoriamente alcoolizados.

Um dos profissionais foi treinado para atuar como supervisor do trabalho que tinha como atribuição a revisão de cada ficha para detecção de possiveis erros e/ou omissões do preenchimento. No caso da ocorrência destes problemas as fichas eram corrigidas pelos coletores dos dados.

\subsection{Testando a Ficha de Notificação}

Além de se testar a validade de face, e de se realizar o estudo piloto procurouse verificar através de reteste a qualidade, estabilidade e consistência dos dados obtidos. Dois técnicos com experiência em pronto-socorro e epidemiologia reentrevistaram setenta e três pacientes portadores de agravos à saúde causados por causas externas (por volta de vinte por cento do grupo estudado) e quarenta e quatro que procuraram o serviço por outros problemas, num total de 117 indivíduos. $\mathrm{Na}$ reentrevista aplicou-se a ficha utilizada para a notificação de causas externas no pronto-atendimento. As entrevistas ocorreram no domicílio do paciente ou em seu local de trabalho quando ele lá se encontrasse. Os entrevistadores não tinham quaisquer informações prévias a respeito dos entrevistados, além de seus nomes e endereços. A amostra que passou por uma nova entrevista foi selecionada a partir de tabela de números aleatórios gerados pelo programa EPITABLE que faz parte do pacote EPI-INFO 6.04 (DEAN e cols, 1994) de dominio público. O material obtido serviu como base de comparação para testes de confiabilidade do instrumento trabalhado.

O grau de concordância entre as respostas dadas aos questionários e os prontuários foi estimado através do percentual bruto de acordos (GARCIAMONTRONE \& ROSE, 1996; SANTANA e cols, 1997). Para a análise de confiabilidade com medidas ajustadas para concordância aleatória utilizou-se 0 indice Kappa (FLEISS, 1981), o Kappa ajustado para viéses (BAK) e o mesmo indice ajustado para viéses e prevalência (PABAK). $\mathrm{O}$ índice Kappa é utilizado para medir a confiabilidade de técnicas que resultam em medidas de variáveis discretas, com pequeno número de categorias (KLEIN \& BLOCH, 2002). Varia de menos um a mais um e quanto mais se aproxima do valor mais um $(+1,00)$ mais forte será a 
confiabilidade do instrumento sob teste, menos um significa completo desacordo. Um valor igual a zero pode ser interpretado como um achado totalmente devido ao acaso. PEREIRA (1995) adaptando proposta de Landis, Jr \& Koch (1977), sugere uma forma de interpretar o índice Kappa $(\mathrm{K})$ : menor que 0,00 concordância ruim; 0,00 - 0,20 fraca; $0,21-0,40$ sofrível; $0,41-0,60$ regular; $0,61-0,80$ boa; $0,81-0,99$ ótimo; 1,00 perfeita . Foi calculado o intervalo de confiança e o erro padrão para o K. Utilizou-se o índice Kappa $(\mathrm{K})$ como medida de concordância porque o percentual bruto de acordos pode sofrer forte influência de uma das respostas se essa ocorrer em grande quantidade. Kappa tem a vantagem de, por ser um indicador de concordância ajustada, levar em consideração, no cômputo final, a concordância devida ao fator chance. Para o cálculo do índice Kappa utilizou-se o programa de computador PEPI 4.0x (Computer Programs for Epidemiologists; 2001, disponível na Internet em www.myatt.demon.co.uk/index.htm), de domínio público.

\subsection{O Banco de Dados}

Construiu-se banco de dados formatando-se inicialmente um questionário de entrada, baseado na Ficha de Notificação, adaptando-o para que uma posterior análise pudesse se processar de forma adequada e ainda, que não surgissem dificuldades na consolidação das informações. Para esta finalidade utilizou-se o programa EPED constante do EPI-INFO 6.04 (DEAN e cols, 1994). A entrada dos dados se deu pelo programa ENTER do referido pacote.

\subsection{Medidas Utilizadas}

Os dados foram apresentados em números absolutos, proporções e taxas, em tabelas e figuras. Quando houve necessidade de utilização da população do município de Pouso Alegre foram utilizados os valores obtidos em Censos demográficos e/ou contagens populacionais. Quando o denominador usado foi a população de regiões da cidade utilizaram-se estimativas obtidas a partir dos serviços municipais (IPTU). Nos periodos intercensitários trabalhou-se com estimativas cio Instituto Brasileiro de Geografia e Estatistica (IBGE) obtidas no site da Internet do DATASUS. As informações obtidas, sempre que possivel foram comparadas com valores obtidos em outros trabalhos no Brasil e em outros países. 


\subsection{Investigação de Associações}

Os dados obtidos no presente trabalho possibilitaram levantarem-se hipóteses a respeito da provável existência de associações entre agravos ocasionadas por causas externas e outras variáveis. 


\section{4 - RESULTADOS E DISCUSSÃO}

A população de estudo constituiu-se de 380 vítimas de causas externas de morbidade e mortalidade que foram atendidas pelo serviço de pronto-atendimento da Prefeitura Municipal de Pouso Alegre, Minas Gerais entre fevereiro e junho de 2003. Inicialmente também seriam estudados os pacientes que demandassem $o$ Pronto-Socorro do Hospital Universitário local que entretanto, por motivos administrativos. suspendeu os atendimentos às urgências no período do estudo, se limitando a receber os casos que necessitassem de uma cobertura de UTI, de cirurgia e de internação hospitalar. Optou-se então em se atuar numa área descoberta pelos sistemas de informações oficiais, ou seja, no pronto-atendimento, uma vez que os usuários do pronto- socorro, em sua esmagadora maioria, foram neste período, quase sempre hospitalizados, passando a informação a seu respeito a ocorrer via SIH/SUS. Todos estes pacientes tiveram, no momento de seu atendimento, preenchida uma ficha de notificação de causas externas e não se registrou qualquer recusa para fornecimento de informações, tanto por parte da vítima, como por seu eventual acompanhante.

Foi critério de exclusão deste estudo o local de residência do paciente (excluiu-se os moradores de outros municipios). Tal decisão foi motivada pela necessidade de se delimitar a área de abrangência do trabalho, pois sua indefinição pode trazer sérios problemas no momento de se determinar quais serão denominadores dos indicadores a serem trabalhados. Esta pesquisa não se propõe investigar toda a abrangência da morbidade por causas externas da cidade de Pouso Alegre. Entretanto, ela vai contemplar a maior parte dos indivíduos que apresentaram esses agravos no município, apesar de não exprimir, exatamente a prevalência total. Para que se conheça a real abrangência do problema seria necessário que se levantassem também os atendimentos de emergência realizados no Hospital Universitário, os pacientes que sem passar por quaisquer serviços foram diretamente internados, os atendimentos efetuados na rede privada, os óbitos ocorridos antes que se obter atenção médica, além daqueles casos indetectáveis das pessoas com lesões extremamente leves e que, por isso, não necessitam do concurso de um serviço de saúde. Os escolhidos para o estudo são os pacientes que sofreram problemas de saúde como conseqüência de causas externas, que foram atendidos no pronto- 
atendimento municipal e que eram residentes em Pouso Alegre.

Foi elaborada uma ficha (anexo 1) que propiciou a coleta dos dados diretamente junto à população estudada. A opção para uso deste instrumento foi decidida por algumas características e possibilidades em termos da sua praticidade, da acurácia da informação a ser produzida e dos recursos disponíveis para a realização do trabalho:

- disponibilidade de pessoal de bom nivel cultural (enfermeiras), capacitadas e com facilidade para o preenchimento da ficha de notificação mediante treinamento;

- não se necessitar de emprego de exames, equipamentos e procedimentos que demandassem uma tecnologia sofisticada;

- aceitabilidade do instrumento pelos pesquisados, reduzindo a possibilidades de não-participação:

- probabilidade de esse método conseguir uma boa cobertura da população de interesse.

Foi escolhida a alternativa de se trabalhar principalmente com perguntas fechadas. Questões deste tipo, apesar de trazerem resultados mais pobres em detalhes, apresentam maior facilidade para a interpretação das respostas, uniformizando e simplificando a análise (ABRAMSON, 1990). Procurou-se levantar o maior número de circunstâncias que pudessem estar relacionadas com as causas externas. Não foi pretensão do presente trabalho esgotar o tema, mas sim, tentar, dentro das suas possibilidades e recursos, desenvolver um instrumento capaz de coletar informações que pudessem contribuir para a compreensão dos problemas de saúde provocados por acidentes e violências. Algumas questões foram apresentadas de forma aberta, principalmente quando se buscou a descrição do evento gerador do caso estudado e ainda, do detalhamento quanto às características das lesões apresentadas.

Para uniformização das entrevistas, foi elaborado um manual de instruções (anexo 4), padronizando-se o preenchimento do formulário. Ele foi muito importante durante o treinamento e trabalho de campo dos entrevistadores. Estes foram selecionados na equipe de enfermagem do pronto-atendimento. A opção em se trabalhar com os enfermeiros revelou-se acertada pois estes profissionais se esmeraram em fazer com que a proposta do estudo fosse alcançada.

- Para que o estudo ocorresse de maneira satisfatória foi de grande 
importância a realização do treinamento. Este foi um momento de se discutir em profundidade tanto a proposta do trabalho, como a maneira de se atuar na coleta de dados, e ainda, para se uniformizarem as condutas no preenchimento das fichas. Numa de suas fases, que também foi importante, para a continuidade do teste da ficha de notificações, a realização de um estudo piloto. Como resultados este apresentou uma série de propostas (anexo 2), que foram importantes para prover homogeneização e sedimentação dos procedimentos, estabelecer o fluxo de trabalho, e ainda, propor modificações a serem feitas no instrumento de coleta de dados $O$ estudo piloto também serviu para sanar as dúvidas dos entrevistadores em relação à aplicação do questionário. Foi uma atividade crucial para que não se tivesse de fazer modificações nas estratégias do trabalho quando este já se encontrasse num estágio mais avançado, o que traria enorme transtorno para o seu andamento.

Treinamento especifico, realização de estudo piloto, intensa discussão de cada dúvida surgida e empenho no registro de toda a população a ser estudada foram fatores que contribuiram qualitativamente para os resultados obtidos.

O preenchimento da ficha de notificação após os treinamentos e familiarização dos entrevistadores com seu manejo levou em média sete minutos e a moda foi cinco minutos.

Os resultados relativos às causas externas encontradas, circunstâncias de sua ocorrência, caracteristicas dos pacientes e do atendimento prestado, conseqüências para a saúde das vítimas foram totalmente levantadas a partir das fichas preenchidas no pronto-atendimento. Dois técnicos da Secretaria Municipal de Saúde também visitaram a residência de 73 pacientes que já tinham sido atendidos anteriormente no pronto-atendimento devido a causas externas e a outros 44 que lá haviam comparecido por outros motivos; para controle da qualidade e da confiabilidade das informações colhidas. Nessa ocasião a ficha de notificação era preenchida pela segunda vez, quando se tratava de paciente de causa externa. Este novo formulário serviu como base para comparação com a ficha preenchida durante a passagem do paciente pelo PA. Os entrevistadores desta fase do trabalho não possuíam quaisquer conhecimentos a respeito do que continha a ficha original do paciente, exceto nome e endereço. Esse procedimento detectou alguns viéses principalmente em relação à lembrança por parte do paciente de datas, horários e detalhes relativos ao 
atendimento. Houve situações em que pacientes que afirmaram no momento do atendimento que tinham sido vítimas de violências na reentrevista diziam que a causa externa envolvida seria outra. Também aconteceu de pessoas cujos formulários na primeira coleta de dados apresentavam como causa outras causas externas de traumatismo acidental trazerem na reentrevista o registro de agressão.

As fichas preenchidas no estudo piloto e as da reentrevista não foram utilizadas para a coleta dos dados epidemiológicos apresentados neste trabalho e sim para a avaliação do instrumento de notificação.

\subsection{A Ficha de Notificação de Causas Externas}

\subsubsection{A confiabilidade da ficha de notificação}

Para que um sistema de informações funcione adequadamente ele deve ter seus instrumentos de coleta de dados confiáveis. Quando se diz que determinados dados têm confiabilidade provavelmente existe a manutenção da estabilidade dos resultados obtidos com um mesmo instrumento nas mãos de diferentes pesquisadores e de diferentes avaliadores. A confiabilidade então, mede a estabilidade e a consistência da coleta de dados e da avaliação (ALMEIDA FILHO \& ROUQUAYROL, 2002).

Como foi informado acima os resultados da reentrevista do paciente estiveram sujeitos a viéses. Por estes problemas este instrumento não foi adequado ao papel de padrão-ouro. Por isso, a determinação da sensibilidade, especificidade e valores preditivos da ficha de notificação não puderam ser efetuados. Entretanto, as taxas brutas de concordâncias e o indice Kappa, podem ser calculados sem maiores problemas. Foram selecionadas as doze perguntas mais respondidas da ficha de notificação para serem submetidas ao estudo de concordância:

1. localização da lesão: cabeça

2. localização da lesão: membros superiores;

3. localização da lesão: membros inferiores;

4. tipo de lesão: ferimentos;

5. tipo de lesão: traumatismos superficiais,

6. tipo de causa externa: outras causas externas de traumatismos acidentais;

7. tipo de causa externa: acidente de transporte; 
8. tipo de causa externa: agressões:

9. local de ocorrência: residência;

10. local de ocorrência: rua;

11. local de ocorrência: local de trabalho;

12. destino do paciente: alta.

Estas questões foram os achados mais comuns nas fichas preenchidas no estudo inicial. Deve-se evitar a utilização de perguntas pouco respondidas pois os valores marginais das tabelas e a baixa prevalência de um evento influenciam o Kappa, fazendo com que assuma valores baixos (PEREIRA, 1995).

Nas tabelas $\mathbf{5 . 1}$ a $\mathbf{5 . 1 2}$ se encontram os resultados encontrados em relação à concordância das variáveis acima listadas. 
Tabelas 1 - Concordância entre ficha de notificações e reentrevista de pacientes atendidos devidos a causas externas no serviço municipal de pronto-atendimento em Pouso Alegre, MG, por tópico.

Tabela 1.1 - Local afetado: Cabeça

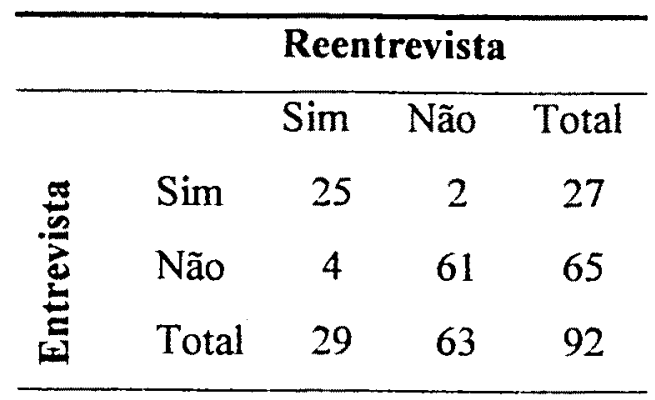

Tabela 1.3 - Local afetado:

Membros inferiores

\begin{tabular}{|c|c|c|c|c|}
\hline & & Reer & revist & \\
\hline & & Sim & Não & Total \\
\hline & Sim & 15 & 2 & 17 \\
\hline $\bar{d}$ & Não & - & 75 & 75 \\
\hline Б्ञ & Total & 15 & 77 & 92 \\
\hline
\end{tabular}

Tabela 1.5 - Tipo de lesão:

Traumatismo superficial

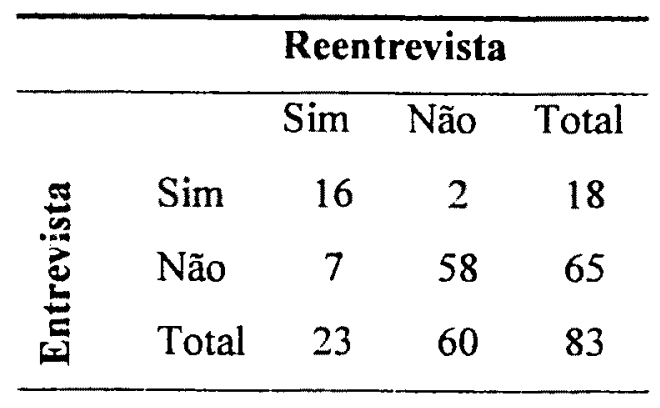

Tabela 1.2 - Local afetado:

Membros superiores

\begin{tabular}{|c|c|c|c|c|}
\hline \multicolumn{5}{|c|}{ Reentrevista } \\
\hline \multirow{4}{*}{ 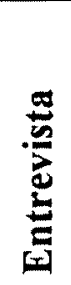 } & & Sim & Não & Total \\
\hline & $\operatorname{Sim}$ & 31 & - & 31 \\
\hline & Não & 1 & 60 & 61 \\
\hline & Total & 32 & 60 & 92 \\
\hline
\end{tabular}

Tabela 1.4 - Tipo de lesão: Ferimento

\begin{tabular}{|c|c|c|c|c|}
\hline \multicolumn{5}{|c|}{ Reentrevista } \\
\hline \multirow{4}{*}{ 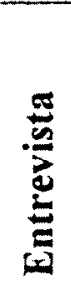 } & & Sim & Não & Total \\
\hline & Sim & 47 & 9 & 56 \\
\hline & Não & 2 & 25 & 27 \\
\hline & Total & 49 & 34 & 83 \\
\hline
\end{tabular}

Tabela 1.6 - Tipo de Causa externa: Outras causas externas de traumatismos acidentais

\begin{tabular}{|c|c|c|c|c|}
\hline \multicolumn{5}{|c|}{ Reentrevista } \\
\hline \multirow{4}{*}{$\frac{5}{\frac{5}{2}}$} & & Sim & Não & Total \\
\hline & Sim & 46 & 02 & 48 \\
\hline & Não & 05 & 20 & 25 \\
\hline & Total & 51 & 22 & 73 \\
\hline
\end{tabular}


Tabela 1.7 - Tipo de Causa

externa: Acidentes de transporte

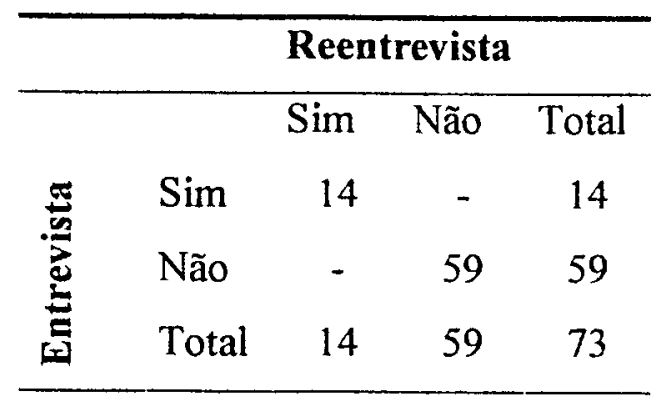

Tabela 1.9 - Local de ocorrência:

Residência

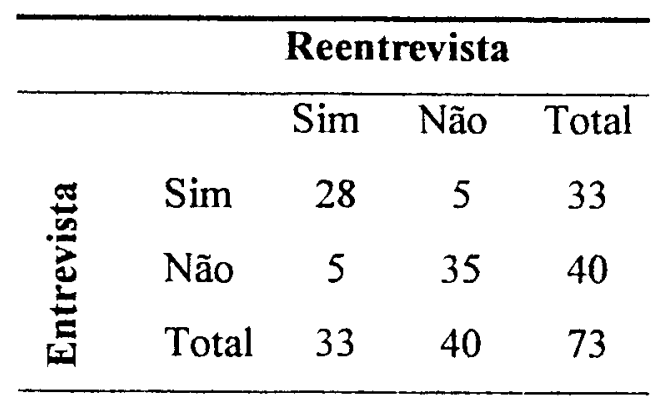

Tabela 1.11 - Local de

ocorrência: Local de trabalho

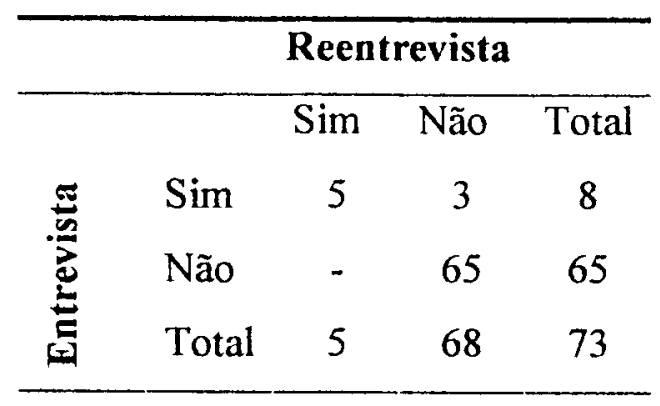

Tabela 1.8 - Tipo de causa externa: Agressões

\begin{tabular}{|c|c|c|c|c|}
\hline \multicolumn{5}{|c|}{ Reentrevista } \\
\hline \multirow{4}{*}{ 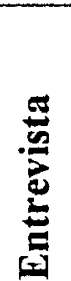 } & & Sim & Não & Total \\
\hline & Sim & 3 & 6 & 9 \\
\hline & Não & 2 & 62 & 64 \\
\hline & Total & 5 & 58 & 73 \\
\hline
\end{tabular}

Tabela 1.10 - Local de ocorrência: Rua

\begin{tabular}{|c|c|c|c|c|}
\hline \multicolumn{5}{|c|}{ Reentrevista } \\
\hline \multirow{4}{*}{ 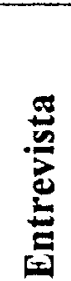 } & & Sim & Não & Total \\
\hline & Sim & 18 & 3 & 21 \\
\hline & Não & 7 & 45 & 52 \\
\hline & Total & 25 & 48 & 73 \\
\hline
\end{tabular}

Tabela 1.12 - Destino: Alta

\begin{tabular}{|c|c|c|c|c|}
\hline \multicolumn{5}{|c|}{ Reentrevista } \\
\hline \multirow{4}{*}{ 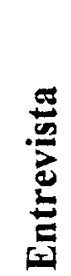 } & & Sim & Não & Total \\
\hline & Sim & 61 & 07 & 68 \\
\hline & Não & 02 & 03 & 05 \\
\hline & Total & 63 & 10 & 73 \\
\hline
\end{tabular}

Os totais variam em função do número de respondentes de cada questão.A partir destes resultados foram calculadas as proporções brutas de concordância e os índice Kappa de cada uma. 
- Proporções Brutas de Concordância

A tabela 2 mostra as proporções brutas de concordância por variável. Se forem olhadas de forma individualizada, apenas em seu total, podemos dizer que foram muito expressivas. No total, a variável que apresentou o maior percentual de concordâncias foi acidentes de transporte, com $100 \%$, e a de menor foi a localização do evento na residência ou na rua com $86 \%$ cada uma, o que são bons resultados. Esta situação muda quando se estudam as concordâncias por resposta dada à questão, ou seja por categoria ( $\operatorname{sim}$ ou não). Os acidentes de transportes, com $100 \%$ nas duas categorias, foram as que mostraram o maior número de acordos. Alta, apesar do total de concordâncias de $88 \%$, mostrou grande disparidade por categoria: sim com $97 \% \mathrm{e}$ não com $40 \%$. Isso mostra que o percentual bruto de acordos pode sofrer forte influência de uma das respostas se essa ocorrer em grande quantidade (MESQUITA FILHO e cols, 1998), o que indica o uso de indice que minimize esse tipo de influencia como o Kappa. 
Tabela 2- Proporções (\%) brutas de concordància e seus intervalos de confiança (IC, 95\%) para respostas de questões selecionadas da ficha de notificação de causas externas e reentrevista em pacientes atendidos por serviço de atenção às urgências no município de Pouso Alegre, MG, fevereiro a junho de $2003(n=73)$.

\begin{tabular}{|c|c|c|c|}
\hline $\begin{array}{l}\text { QUESTÕES SELECIONADAS } \\
\text { NA FICHA DE NOTIFICAÇÃO }\end{array}$ & $\begin{array}{l}\text { \% Total de } \\
\text { concordân- } \\
\text { cias }\end{array}$ & $\begin{array}{c}\text { \% de } \\
\text { concordâncias } \\
\text { para a resposta } \\
\text { SIM }\end{array}$ & $\begin{array}{c}\text { \% de concordâncias } \\
\text { para a resposta } \\
\text { NÂO }\end{array}$ \\
\hline Localização da lesão: cabeça & 93 & $89($ IC:70-97) & 95 (IC: $86-99)$ \\
\hline $\begin{array}{l}\text { Localização da lesão: membros } \\
\text { superiores }\end{array}$ & 99 & 98 (IC: $84-100)$ & 99 (IC: $91-100)$ \\
\hline $\begin{array}{l}\text { Localização da lesão: membros } \\
\text { inferiores }\end{array}$ & 98 & $94(\mathrm{IC}: 67-100)$ & $99(\mathrm{IC}: 92-100)$ \\
\hline Tipo de lesão: ferimentos & 87 & 90 (IC: 77-96) & 82 (IC: 62-93) \\
\hline $\begin{array}{l}\text { Tipo de lesão: traumatismos } \\
\text { superficiais }\end{array}$ & 89 & 78 (IC: $52-93)$ & 93 (IC: 82-98) \\
\hline $\begin{array}{l}\text { Tipo de causa externa: outras } \\
\text { causas externas de traumatismos } \\
\text { acidentais }\end{array}$ & 90 & 93 (IC: $81-98)$ & 85 (IC: 63-96) \\
\hline $\begin{array}{l}\text { Tipo de causa externa: acidente de } \\
\text { transporte }\end{array}$ & 100 & $100(\mathrm{IC}: 73-100)$ & 100 (IC: $92-100)$ \\
\hline Tipo de causa externa: agressões & 89 & 43 (IC: 08-85) & 94 (IC:84-98) \\
\hline Local de ocorrência: residência & 86 & 85 (IC: 67-94) & 87 (IC: 72-95) \\
\hline Local de ocorrência: rua & 86 & 78 (IC: $55-92)$ & $90(\mathrm{IC}: 77-96)$ \\
\hline $\begin{array}{l}\text { Local de ocorrência: local de } \\
\text { trabalho }\end{array}$ & 96 & 77 (IC:28-98) & 98 (IC: $90-100)$ \\
\hline Destino do paciente: alta & 88 & 97 (IC: 83-98) & 40 (IC: 07-83) \\
\hline
\end{tabular}

IC: Intervalo de confiança para $95 \%$

Em agressão também se encontrou alta disparidade entre as respostas: $43 \%$ para o sim e $94 \%$ para o não. A localização de lesão nos membros superiores teve alto percentual de acordos, tanto total (99\%), assim como nas resposta sim (98\%) e 
não $(99 \%)$. Os resultados encontrados foram superiores aos encontrados por MESQUITA FILHO e cols (1998) quando foi feito estudo de concordâncias entre prontuários e entrevistas domiciliares para acidentados no trânsito.

Os intervalos de confiança em oito ocasiões tiveram uma variação superior a $30 \%$, sendo que quando a causa externa foi agressão e o destino foi alta não, estes foram muito extensos ( 8 a $85 \%$ e 7 a $83 \%$ respectivamente). Os intervalos de confiança que apresentam grande amplitude entre suas extremidades, geralmente têm esta característica pelo pequeno tamanho da amostra estudada, o que pode ser o que aconteceu nesta situação, aliando-se nos dois casos mais extremos também à existência de alta proporção de falsos positivos e falsos negativos (tabelas 5.8 e 5.12). Em relação às agressões, reafirmam-se os comentários já feitos anteriormente, sobre a alta incidência de viéses neste tipo de resposta. Já os intervalos menores ocorreram nas respostas negativas para acidente de transporte (92 a 100\%), membros inferiores (92 a 100\%) e membros superiores (91 a 100\%). É interessante notar que estas foram as questões onde se encontrou as melhores proporções brutas de concordância, respectivamente $100 \%, 98 \%$ e $99 \%$.

- Concordância entre a entrevista e reentrevista através do índice Kappa

Os indices de concordância medidos pelo Kappa estão mostrados na tabela $\mathbf{3}$, bem como seus intervalos de confiança e valores ajustados. O Kappa não-ajustado variou entre 0,34 e 1,00 . Seu valor em média foi de 0,74 com um desvio padrão de 0,21. Apresentou, utilizando-se dos critérios de Landis, Jr \& Koch apresentados no livro de PEREIRA, MG (1995), os seguintes resultados:

- concordância perfeita: acidente de transporte;

- concordância ótima para cabeça, membros superiores, membros inferiores;

- concordância boa: ferimentos,traumatismos superficiais, outras causas externas de traumatismos acidentais, residência, rua e local de trabalho;

- concordância sofrivel: agressões e alta.

Não houve itens que se enquadrassem na classificação ruim. Entretanto, como alertam KLEIN \& BLOCH (2002), "a interpretação do indice Kappa deve ser feita com cuidado. Kappa não é uma proporção e não possui as propriedades das proporções", podendo variar dependendo dos valores das marginais das tabelas. 
Tabela 3 - Concordância entre medidas efetuadas pela ficha de notificação para causas externas e reentrevista em serviço municipal de atendimento a urgências em Pouso Alegre, MG, entre fevereiro e junho de 2003, através do indice Kappa bruto e seu intervalo de confiança (IC, 95\%), e o ajustado.

\begin{tabular}{|c|c|c|c|c|}
\hline \multirow{2}{*}{$\begin{array}{l}\text { QUESTÕES SELECIONADAS } \\
\text { NA FICHA DE NOTIFICAÇÃO }\end{array}$} & \multirow{2}{*}{ Kappa } & \multirow{2}{*}{ IC $95 \%$} & \multicolumn{2}{|c|}{ Kappa ajustado } \\
\hline & & & PABAK * & $\mathbf{B A K}^{* *}$ \\
\hline Localização da lesão: cabeça & 0,85 & $0,73-0,96$ & $\overline{0,87}$ & 0,85 \\
\hline $\begin{array}{l}\text { Localização da lesão: membros } \\
\text { superiores }\end{array}$ & 0,98 & $0,93-1,00$ & 0,98 & 0,98 \\
\hline $\begin{array}{l}\text { Localização da lesão: membros } \\
\text { inferiores }\end{array}$ & 0,92 & $0,82-1,00$ & 0,96 & 0,92 \\
\hline Tipo de lesão: ferimentos & 0,72 & $0,56-0,87$ & 0,73 & 0,71 \\
\hline $\begin{array}{l}\text { Tipo de lesão: traumatismos } \\
\text { superficiais }\end{array}$ & 0,71 & $0,53-0,89$ & 0,78 & 0,71 \\
\hline $\begin{array}{l}\text { Tipo de causa externa: outras causas } \\
\text { externas de traumatismos acidentais }\end{array}$ & 0,78 & $0,63-0,93$ & 0,81 & 0,78 \\
\hline $\begin{array}{l}\text { Tipo de causa externa: acidente de } \\
\text { transporte }\end{array}$ & 1,00 & $0,84-1,00$ & 1,00 & 1,00 \\
\hline Tipo de causa externa: agressões & 0,37 & $0,03-0,71$ & 0,78 & 0,37 \\
\hline Local de ocorrência: residência & 0,72 & $0,56-0,88$ & 0,73 & 0,72 \\
\hline Local de ocorrēncia: rua & 0,68 & $0,50-0,86$ & 0,73 & 0,72 \\
\hline $\begin{array}{l}\text { Local de ocorrência: local de } \\
\text { trabalho }\end{array}$ & 0,75 & $0,48-1,00$ & 0,92 & 0,75 \\
\hline Destino do paciente: alta & 0,34 & $0,06-0,62$ & 0,75 & 0,33 \\
\hline
\end{tabular}

* PABAK-Kappa ajustado para viéses e para prevalência.

** BAK - Kappa ajustado para viéses.

Entre os fatores que devem ser levados em conta estão (PEREIRA, 1995):

1- Tipo de evento e outros fatores : "são essenciais à clara definição do evento, regras inequivocas da mensuração e esquemas de classificação apropriados", para que o estudo não incorra em viéses. 
2- Prevalência: "é possível encontrar baixos níveis de reprodutibilidade (Kappa igual ou inferior a 0,40 ), devido à baixa prevalência do diagnóstico empregado e não a erros substanciais relacionados ao procedimento diagnóstico empregado".

3- Independência da avaliação - "um examinador ao repetir o exame deve ignorar resultados prévios, (...) sob pena de ser influenciado por este conhecimento e deturpar a avaliação, mesmo involuntariamente".

Então, Kappa pode ser afetado por erros oriundos da diferença das proporções dos falso-positivos e falso-negativos encontrados no estudo (tipo de evento e outros fatores), expressos da tabela $2 \times 2$ como células b e c, especialmente se o valor encontrado para o índice é baixo, bem como pela diferença entre as prevalências dos verdadeiros positivos (prevalências) nas categorias estudadas (células a e d). Para diminuir a influência destas distorções são efetuados ajustes. Quando ajusta-se apenas para a correção dos viéses (advindos da influência dos falso-positivos e falsonegativos) temos o Kappa ajustado para viéses (BAK - bias-adjusted Kappa). Quando além de se corrigir a influência dos viéses também se retificam as das prevalências (influência dos verdadeiro-positivos e verdadeiro-negativos) obtém-se aí o Kappa ajustado para viéses e prevalência ( $P A B A K$ - prevalence-adjusted biasadjusted Kappa).

Quando na tabela 3 estudam-se os valores ajustados do Kappa pode-se notar que quando se utiliza exclusivamente o PABAK, a correção dos erros em conjunto com a das prevalências atuam fortemente nos indicadores agressões (de 0,37 passa a 0,78 ) e alta (de 0,34 para 0,75 ) que conforme discutido anteriormente foram os que mais apresentaram problemas desde sua primeira coleta até a reentrevista. Os demais apresentaram nenhuma ou discretas variações quando se comparou o Kappa com o PABAK: acidentes de transportes e membros superiores nenhuma diferença; as demais variáveis com variações que vão de 0,01 a 0,07 . $O$ indice com ajustamento exclusivo para viéses (BAK) apresentou discreto efeito sobre as variáveis estudadas: com exceção de ferimentos, ocorrência na rua e alta, os BAK das demais variáveis apresentaram-se idênticos aos Kappa. Ferimentos e alta tiveram variação de 0,01, já rua variou num intervalo maior: 0,04, porém ainda, de pequena amplitude. Estes resultados também se revelaram melhores do que aqueles resultantes de comparação entre entrevista e prontuários de pronto-socorro do estudo de MESQUITA FILHO e 
cols, 1998.

Os intervalos de confiança também variaram partindo de regiões de concordância fraca (alta e agressões), outras que ficavam em um território de maior concordância, acima de 0,80 (membros superiores, membros inferiores, acidentes de transporte). Excetuando-se alta e agressões o valor mínimo dos intervalos de confiança dos Kappa estudados foi de 0,48. A maior amplitude dos intervalos encontrados foi de 0,68 em agressões (de 0,03 a 0,71 ), seguida de $0,56 \mathrm{em}$ alta $(0,06$ a 0,62$)$ e de 0,52 em local de trabalho $(0,48$ a 1,00). O intervalo de menor diferença entre seus valores máximo e mínimo foi localização em membros superiores com um valor de 0,07 .

Nenhum dos intervalos de confiança passou em qualquer ocasião por valores menores ou iguais a zero, ou seja, em nenhum momento houve prevalência de acordos ocorridos por acaso ou ausência de concordância.

\subsubsection{0 nuxo das informações}

$\mathrm{O}$ individuo, quando chegava para receber o atendimento no serviço, geralmente o fazia sem ter passado por quaisquer procedimentos prévios. No municipio de Pouso Alegre o grupo que atua em atendimento pré-hospitalar é ligado ao corpo de bombeiros, sendo acionado principalmente em situações de maior gravidade. Assim, a maioria dos pacientes vinha ao serviço de maneira espontânea, em busca do primeiro atendimento ao seu agravo. A partir do momento em que eles se apresentavam eram imediatamente identificados e encaminhados para a sala de atendimentos. Durante a identificação, a área administrativa, responsável pela recepção, preenchia o cabeçalho da ficha de notificação, com os dados pessoais e hora de entrada. A pessoa era examinada pelo médico plantonista que definia o procedimento a ser tomado. Neste momento se coletavam informações relativas às causas externas e aos agravos ocorridos, através de um profissional de enfermagem, devidamente treinado, que utilizava a ficha de notificação. A coleta, na maior parte das vezes, foi feita diretamente entrevistando-se a vítima. Alternativamente, quando tal não era possível, se fazia junto ao acompanhante. As informações eram coletadas em duas vias, uma a ser arquivada no serviço e outra que era encaminhada à secretaria municipal de saúde. O formulário, uma vez preenchido, era encaminhado 
para a supervisão, exercida pela coordenação do serviço, que submetia a ficha a uma primeira revisão crítica. Se fossem constatados erros, incongruências ou omissões ela retornava ao responsável pelo preenchimento que cuidava de sua correção. Após este procedimento, a ficha era novamente encaminhada ao supervisor que, se não houvesse problemas, a enviava para a Secretaria Municipal de Saúde. Esse processo ocorria, no máximo, em um dia.

Em média, o tempo de preenchimento foi de seis minutos e cinqüenta $\mathrm{e}$ quatro segundos. Tal tempo parece um pouco dilatado; entretanto, ele é fruto de média entre valores extremos, não refletindo corretamente a realidade pois houve preenchimentos que duraram um minuto e outros vinte. Para se ter uma melhor noção do tempo gasto, a moda de preenchimento foi de cinco minutos, em $41,9 \%$ dos casos.

$\mathrm{Na}$ Secretaria, a ficha chegava ao setor de epidemiologia, onde sofria nova critica, através de técnico do setor. Se se constatasse, novamente, algum erro, omissão ou impropriedade ocorria nova devolução ao serviço para correção, o que deveria acontecer em um prazo maximo de 24 horas. Se nada fosse verificado, passava-se à digitação para sua incorporação ao banco de dados construído, utilizando-se o programa Epi-Info 6.04. Após sua incorporação, já era possivel, de imediato, disponibilizarem-se informações para os serviços de saúde municipais.

Esse fluxo teve algumas dificuldades iniciais, durante o estudo piloto, pelo fato de aproximadamente $20,0 \%$ das fichas estarem retornando em função de erros. Após aproximadamente quinze dias de funcionamento, houve uma certa normalização, com a presença de apenas de $2,0 \%$ de formulários com problemas, o que ainda pôde ser melhorado. Os questionários devolvidos, em praticamente todos os casos tiveram suas correções devidamente efetuadas, exceto em três ocasiões em que o erro não tinha ocorrido por falha do preenchimento, mas por recusa do paciente em fornecer determinada informação (pacientes alcoolizados que se recusaram a descrever o evento em que estiveram envolvidos).

O fluxo, no nível da Secreta-ia Municipal de Saúde, seguiu a proposta do trabalho, havendo, entretanto, a necessidade de se testar, posteriormente, as etapas estadual e federal que fogem às possibilidades deste trabalho (figura 5). 


\subsection{VÍtIMAS E CIRCUNSTÂNCIAS DOS AGRAVOS: DISTRIBUIÇÃO, FREQÜÊNCIA E POSSÍVEIS DETERMINANTES}

Os estudos da distribuição, freqüência e possíveis determinantes dos agravos à saúde determinados pelas causas externas de morbidade e mortalidade têm grande importância enquanto forma de aproximação e reconhecimento de uma realidade que tantas conseqüências provoca na população. As informações levantadas têm importante papel no desenho das políticas públicas a serem adotadas, tanto na esfera municipal, como na estadual e na federal. Além disso, servem de marcos para o balizamento das atividades cotidianas dos serviços de saúde tanto ambulatoriais como hospitalares e de reabilitação, e ainda, para o planejamento das suas ações setoriais. Elas também são úteis para orientação e organização de outros setores extra-saúde que possuam interfaces para os problemas das violências e dos acidentes, tais como educação, segurança pública, justiça, planejamento urbano, entre outros.

\subsubsection{Tipos de acidentes e de vinlências}

Conforme pode ser verificado na tabela 4 os eventos que mais causaram lesões na população em estudo foram as chamadas "outras causas externas de traumatismos acidentais" com 73,2\% de freqüência. Nessa classificação se incluem as quedas, afogamentos exposição a forças mecânicas animadas ou não, exposição a calor, eletricidade, fogo e fumaça, contato com animais, exposição às forças da natureza, intoxicações acidentais, entre vários outros. Estes problemas podem afetar a todas as idades, os mais diversos niveis socioeconômicos e os mais variados tipos de ocupação Eles também estão relacionados a ocorrências nas mais diversas locações, desde os acidentes domésticos, acidentes em escolas, locais para prática de esportes, ambientes de trabalho, de lazer (NCIPC, 1996). É importante notar que os acidentes de transporte e as agressões, mais importantes causas de mortalidade em causas externas no Brasil (MINAYO \& SOUZA, 1999; MELLO JORGE, 1988; BRASIL, MINISTÉRIO DA SAÚDE, 2001), aparecem em menor quantidade no local e periodo estudados do que as outras causas acidentais. Esse fato se justifica pela grande proporção de pequenos acidentes, de pouca gravidade, que acontecem principalmente no âmbito doméstico e que procuram os serviços de urgência. 
Tabela 4 - Vítimas por causa externa $\left(N .^{\circ}\right.$ e \%) atendidas em serviço de atenção às urgências no município de Pouso Alegre, MG, fevereiro a junho de 2003.

\begin{tabular}{lcc}
\hline TIPO DE CAUSA EXTERNA & NÜMERO & \% \\
\hline Acidentes de transporte & $\mathbf{5 2}$ & $\mathbf{1 3 , 7}$ \\
- Queda de bicicleta & 33 & 8,7 \\
- Colisão de veiculos & 14 & 3,7 \\
- Atropelamento (vítima = pedestre) & 5 & 1,3 \\
Outras causas externas de traumatismos acidentais & $\mathbf{2 7 8}$ & $\mathbf{7 3 , 2}$ \\
- Queda & 78 & 20,5 \\
- Exposição a forças mecânicas inanimadas & 132 & 34,7 \\
$\quad$ ocontato com objeto cortante(vidro, faca, ferramenta) & 82 & 21,6 \\
o impacto acidental & 42 & 11,1 \\
o contato com máquinas & 8 & 2,1 \\
- Exposição a forças mecânicas animadas & 58 & 15,3 \\
$\quad$ o colisão entre duas pessoas & 3 & 0,8 \\
o mordedura ou golpe provocado por cão & 46 & 12,1 \\
o mordedura ou goipe provocados por outros animais & 9 & 2,4 \\
- Contato com fonte de calor & 4 & 1,1 \\
- Outras & 6 & 1,6 \\
Lesões autoprovocadas volunta riamente & $\mathbf{3}$ & $\mathbf{2 , 1}$ \\
Agressões & $\mathbf{4 1}$ & $\mathbf{1 0 , 8}$ \\
- Por meio de objeto cortante ou penetrante & 13 & 3,4 \\
- Por meio de objeto contundente & 13 & 3,4 \\
- Por meio de força corporal & 14 & 3,7 \\
- Outro & 1 & 0,3 \\
Outros & $\mathbf{1}$ & $\mathbf{0 , 3}$ \\
Desconhecida & $\mathbf{1}$ & $\mathbf{0 , 3}$ \\
\hline TOTAL & $\mathbf{3 8 0}$ & $\mathbf{1 0 0 , 0}$ \\
\hline
\end{tabular}

Os acidentes de transporte constituiram o segundo grupo mais atendido entre as vitimas de causas externas. Ocorreram 52 atendimentos o que correspondeu a 13,7\% dos indivíduos estudados. Esses números diferiram pouco do estudo de DESLANDES (2000) em dois hospitais públicos do Rio de Janeiro que encontrou o percentual de $11,8 \%$ de atendimentos para este tipo de agravo. Apesar de ter atingido uma cifra expressiva entre os atendimentos, o número de vítimas oriundas do município é provavelmente maior. Isso porque os acidentes de trânsito algumas vezes causam óbitos e, além disso, são responsáveis pelo surgimento de casos de alta gravidade. Os pacientes em piores condições devem ter procurado os serviços que oferecem suporte para tratamento intensivo, cirúrgico e de internação. 
Um problema possivel de ter ocorrido no presente estudo é o da subnotificação do item agressões $(10,8 \%)$ pois, muitas vezes, as vítimas de violências domésticas, agressōes sexuais, maltratos a crianças e a mulheres, ocultam a verdadeira causa que as fez buscar o serviço de saúde, por temer represálias por parte do agressor, geralmente pessoa próxima, muitas vezes até residente sob o mesmo teto. O próprio profissional que preenche a notificação deste tipo de causa externa, também pode ser intimidado por um agressor atemorizado com a possibilidade de vir a ser denunciado aos serviços policiais, fato que amplia a possibilidade da subnotificação. "Lesões autoprovocadas" também foram pouco notificadas $(2,1 \%)$. Tal fato também pode estar ocorrendo por subnotificação, uma vez que é comum que individuos nesta situação não desejem que este tipo de evento seja conhecido por outras pessoas.

\subsection{2 -As causas externas de morbidade e mortalidade notificadas}

No item 4.2 .1 e na tabela 4 foram mostradas as causas externas notificadas, classificadas por agrupamento da CID - 10, onde se verificou que a principal causa externa que foi registrada no serviço estudado eram outras causas externas de traumatismos acidentais. Além disso, nela são detalhadas por seção as principais causas externas encontradas.

As quatro principais causadoras de agravos foram "Outras causas externas de traumatismos acidentais" a saber:

- contato com objetos cortantes (W25-W27) que foi responsável por 21,6\% das ocorrências registradas no período. Os principais causadores deste tipo de agravo foram acidentes por contato com vidro cortante, facas e ferramentas manuais:

- quedas (W00-W19) com 20,5\% destas, sendo as mais comuns aquelas do mesmo nível por escorregão,tropeção ou passos em falso, quedas de mobílias, de escadas;

- exposição a forças mecânicas animadas, aí especificamente contato com animais (W54-W55-W57), com 15,3\%. Neste categoria se destacam as mordeduras por cães $(12,1 \%)$; 
- exposição a forças mecânicas inanimadas através de impactos acidentais (W20-W24) que foi responsável por uma proporção de $11,1 \%$ dos problemas ocasionados.

Acidentes de transporte dos tipos quedas de bicicleta $(8,7 \%)$ e colisões de veículos $(3,7 \%)$ vieram em seguida acompanhados por agressões através de força corporal, objetos contundentes e cortantes (todos com 3,4\%). Os acidentes domésticos e aqueles ligados a atividades de lazer, atingem só nos EUA uma média anual de aproximadamente 700.000 óbitos e milhões de atendimentos de lesões nãofatais anuais (NCIPC, 1996). Trata-se de assunto pouco estudado em nosso meio e estes resultados demonstram a necessidade de ampliarem-se os conhecimentos nesta área.

Nos resultados apresentados também se destaca a importância das quedas e a das lesões provocadas por cães. O National Center for Injury Prevention and Control (2001) destaca a que nos EUA, em 1994, cerca de 2,5\% das crianças de menos de quatorze anos de idade sofreram ataques destes animais. No presente estudo, $52,2 \%$ daqueles que sofreram este agravo tinham menos de quinze anos de idade. Quanto às quedas, $51,3 \%$ aconteceram nas residências, sendo $47,4 \%$ de suas vítimas menores de 15 anos.

\subsubsection{Caracteristicas das vítimas}

A tabela 5 traz a distribuição por sexo e idade das vítimas de causas externas. 
Tabela 5 - Vítimas de causas externas de morbidade e mortalidade atendidas em serviço de atenção às urgências no município de Pouso Alegre, MG, fevereiro a junho de 2003 segundo faixa etária e sexo (N. ${ }^{\circ}$ e \%)

\begin{tabular}{|c|c|c|c|c|c|c|}
\hline \multirow{3}{*}{$\begin{array}{l}\text { FAIXA } \\
\text { ETÁRIA (anos) }\end{array}$} & \multicolumn{4}{|c|}{ SEXO } & & \\
\hline & \multicolumn{2}{|c|}{ FEMININO } & \multicolumn{2}{|c|}{ MASCULINO } & \multicolumn{2}{|c|}{ TOTAL } \\
\hline & N. ${ }^{0}$ & $\%$ & $\mathbf{N}^{0}$ & $\%$ & N. ${ }^{0}$ & $\%$ \\
\hline$<1$ & 2 & 0,5 & 1 & $\overline{0,3}$ & 3 & 0,8 \\
\hline 1 a 4 & 19 & 5,1 & 21 & 5,7 & 40 & 10,8 \\
\hline 5 a 9 & 14 & 3,8 & 32 & 8,6 & 46 & 12,4 \\
\hline Menores de 10 & 35 & 9,4 & 54 & 14,6 & 89 & 24,0 \\
\hline 10 a 14 & 10 & 2,7 & 23 & 6,2 & 33 & 8,9 \\
\hline 15 a 19 & 6 & 1,6 & 24 & 6,5 & 30 & 8,1 \\
\hline 10 a 19 & 16 & 4,3 & 47 & 12,7 & 63 & 17,0 \\
\hline 20 a 24 & 10 & 2,7 & 36 & 9,7 & 46 & 12,4 \\
\hline 25 a 29 & 6 & 1,6 & 27 & 7,3 & 33 & 8,9 \\
\hline 30 a 39 & 8 & 2,2 & 49 & 13,2 & 57 & 15,4 \\
\hline 20 a 40 & 24 & 6,5 & 112 & 30,2 & 136 & 36,7 \\
\hline 40 a 49 & 15 & 4,0 & 24 & 6,5 & 39 & 10,5 \\
\hline 50 a 59 & 4 & 1,1 & 15 & 4,0 & 19 & 5,1 \\
\hline 60 a 69 & 5 & 1,3 & 6 & 1,6 & 11 & 3,0 \\
\hline 70 a 79 & 7 & 1,9 & 3 & 0,8 & 10 & 2,7 \\
\hline 80 e mais & 4 & 1,1 & - & - & 4 & 1,1 \\
\hline Ignorada & 1 & $0,3^{*}$ & 8 & $2,1^{*}$ & 9 & $2,4^{*}$ \\
\hline TOTAL & 111 & $29,2^{*}$ & 269 & $70,8^{*}$ & 380 & $100,0^{*}$ \\
\hline
\end{tabular}

Demais percentuais excluem ignorados

\section{- Sexo}

Entre os indivíduos estudados a proporção de homens (70,8 \%) superou a de mulheres $(29,2 \%)$ numa razão de $2,4: 1,0$. Tal resultado em muito se assemelha ao encontrado por DESLANDES \& SILVA (2000), num estudo feito em dois serviços de urgência/emergência de hospitais públicos do Rio de Janeiro onde se levantou que $69,3 \%$ dos pacientes eram de sexo masculino contra $30,7 \%$ de pacientes femininos (razão de 2,3:1,0). Num grande estudo norte-americano (MMWR, 2001) em uma população estimada de trinta e um milhões de indivíduos que foram atendidos em pronto-socorros, no ano de 2.000 , verificou-se que a razão masculino/feminino foi de 1,4:1,0. Estudando acidentados no trânsito, no município de Pouso Alegre, MESQUITA FILHO (1998) encontrou uma razão homem/mulher de 3,1:1,0. Já OTT e cols. (1993) relataram um percentual de acidentados de trânsito do sexo masculino 
de 69,2\% em Porto Alegre, RS. É também fato comprovado que as violências e acidentes causam sobremortalidade masculina às vezes de até 4,5:1,0 (MELLO JORGE \& GOTLIEB, 2.000).

A predominância de vítimas do sexo masculino dá margem à busca de hipóteses que possam fornecer pistas para sua explicação. Estas podem ir desde uma possivel maior exposição, ocasionada por mais ampla inserção no mercado de trabalho, o que colocaria os homens mais em contato com as ruas conforme YUNES (1993), o que, para os dias de hoje, não se justifica, devido à grande inserção da mulher no mercado de trabalho, (MELLO JORGE e cols., 1997), maior independência feminina, ampliação do acesso à direção de automóveis e outros veículos (WATERS e cols, 1993; GAWRYSZEWSKI, 1995; MASSIE e cols, 1995), até estudos que mostram que as mulheres se expõem menos a comportamentos de risco que os homens (NCIPC, 199'7).

\section{- Idade}

A maioria dos pacientes era menor de quarenta anos (77,6\%). Os que tinham idade inferior a vinte anos correspondiam a $41,0 \%$ da população estudada, sendo que $24,8 \%$ tinham menos de dez anos. Havia $15,6 \%$ de pessoas entre quarenta e cinquienta e nove anos e 6,7\% tinham sessenta e mais anos de idade. Em todas as faixas etárias, excetuando a de zero a quatro anos e na de sessenta anos e mais a proporção das vitimas de sexo masculino foi sempre uma ou mais vezes maior que a das mulheres. A idade média foi de 26,3 anos com um desvio padrão de 19,4 anos o que mostra uma dispersão importante entre as idades. A idade mediana foi de 23,0 anos. Para os homens esta média foi de 25,5 anos com um desvio padrão de 16,5 e uma mediana de 24,0. Para as mulheres estes valores corresponderam respectivamente a: $28,1,25,0$ e 22,0 . Ao se estudar a tabela 5 pode-se também verificar que a razão homem/mulher atingiu maior valor entre trinta e trinta e nove anos de idade atingindo a marca de 6,1:1,0.

Esses números diferiram dos do trabalho de DESLANDES \& SILVA (2000) que encontrou uma maior concentração de vítimas de causas externas entre os vinte $\mathrm{e}$ trinta e nove anos. MELLO JORGE e cols. (1997) mostram que entre os cinco e trinta e nove anos são as causas externas as maiores causadoras de óbitos $(65,0 \%$ das 
mortes nesta idade). CONCHA-EASTMAN \& VILLACEVES (2001) discutindo a razão da maior concentração de violências e acidentes entre os jovens colocam que "a população de menor idade tem sido afetada pelo abuso ou descuido infantil, que se associa com a gravidez indesejada na adolescência, presença de apenas um dos pais na vida destes jovens associada ao baixo nível sócio-econômico. Os adolescentes são a população mais afetada por todo o tipo de violência. Esta não se limita apenas à agressão fisica, mas também inclui o abuso sexual, verbal e emocional e o abandono. Ao mesmo tempo se vê freqüentemente influenciada pelas mensagens agressivas e violentas produzidas pelos meios de comunicação de massa. Além de serem as vítimas mais comuns, os jovens são aqueles que com maior freqüência executam atos violentos. As caracteristicas individuais, experiências familiares, o acesso a armas, álcool, drogas, violência política e social afetam com mais frequêencia este grupo de idade, principalmente aos homens. Estas condutas são aprendidas com freqüência em um ambiente familiar violento".

\subsection{4 - Circunstâncias das ocorrências}

\section{- Região de residência}

$\mathrm{Na}$ figura 6 é apresentado o gráfico com a distribuição dos indivíduos que receberam atenção no serviço de saúde devido a lesões provocadas por causas externas. A maior parte dos pacientes era proveniente da região do bairro São João $(35,8 \%)$, onde se situa o serviço estudado. A facilidade do acesso colabora para que mesmo os portadores de lesões de pequena gravidade procurem atendimento. A sua população, constituída predominantemente por individuos de baixa renda, apresenta um risco aumentado para este tipo de agravo (MINAYO, 1994; MINAYO \& SOUZA, 1999; SCHRAIBER \& D'OLIVEIRA, 1999). 25,8\% vieram dos bairros centrais da cidade. Esse volume se justifica pois se trata da região muito populosa e que tem um acesso relativamente fácil ao pronto-atendimento. A região do bairro São Geraldo, também populosa, em que a maioria de seus habitantes é constituida por pessoas de menor poder aquisitivo, também apresentou expressivo comparecimento ao pronto-atendimento $(15,3 \%)$. As demais regiões tiveram um menor número de pacientes, entretanto, tratam-se também de locais que apresentam uma menor 
densidade populacional, apesar de também ocorrerem ali bolsões de desigualdade social e econômica.

Quando estudamos quais foram as regiões que proporcionalmente mais se utilizaram o serviço conforme a sua população apresenta-se uma situação semelhante. A tabela 6 traz informações sobre esta questão.

Figura 6 - Vítimas de causas externas de morbidade e mortalidade atendidas em serviço de atenção às urgências no município de Pouso Alegre, MG, fevereiro a junho de 2003 segundo região de residência (\%).

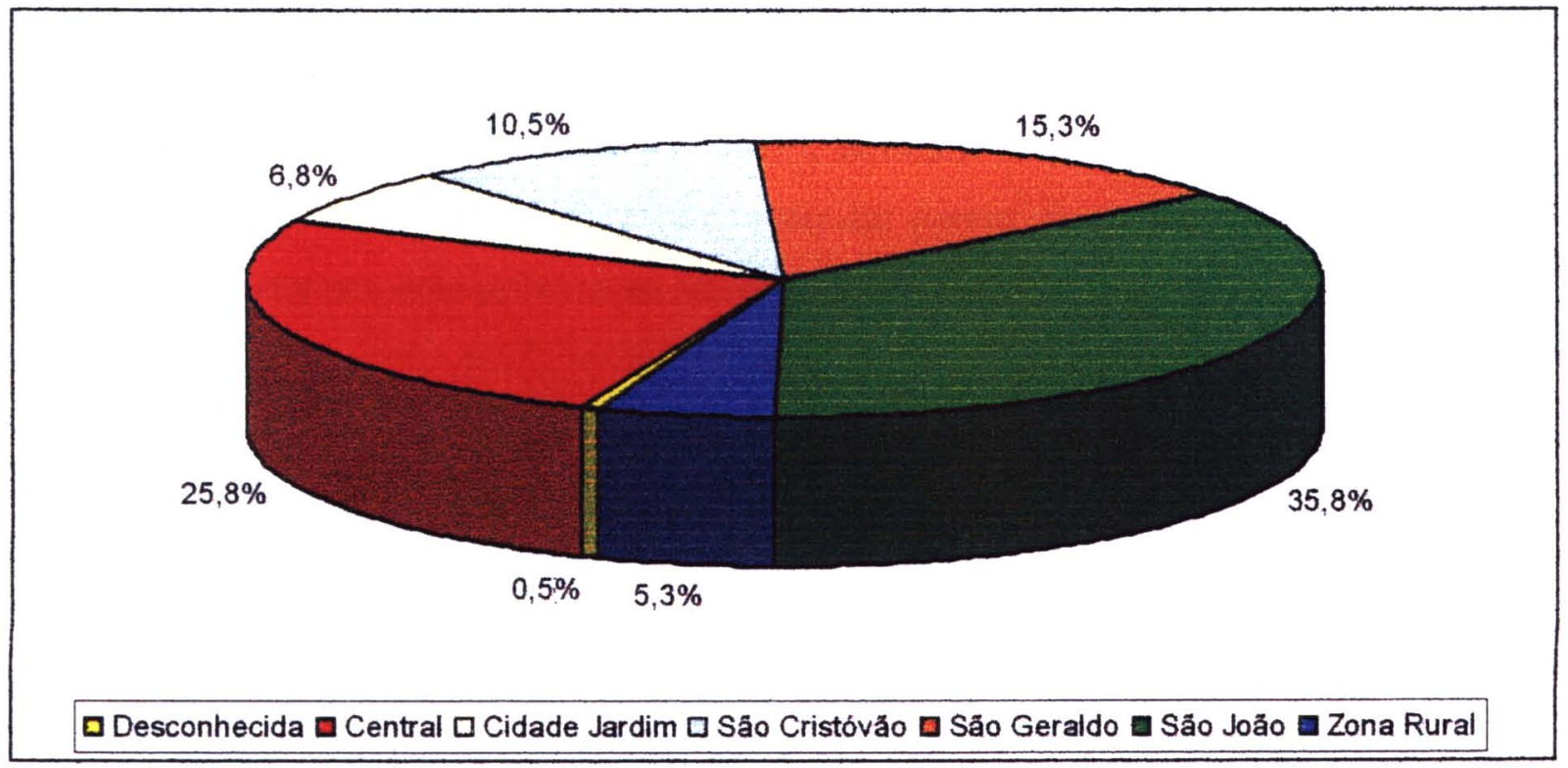

Tabela 6 - Taxa de vítimas pela população da região de residência (por cem mil habitantes) em pacientes com agravos provocados por causas externas de morbidade e mortalidade atendidas em serviço de atenção às urgências no município de Pouso Alegre, MG, fevereiro a junho de 2003 segundo região de residência (N. ${ }^{\circ} \mathrm{e} \%$ ).

\begin{tabular}{lcccc}
\hline REGIAO & N. $^{\circ}$ de vítimas & $\%$ & População & Taxa \\
\hline Desconhecida & 2 & 0,5 & $?$ & $?$ \\
Central & 98 & 25,8 & 35.023 & 279,8 \\
Cidade Jardim & 26 & 6,8 & 9.991 & 260,2 \\
São Cristóvão & 40 & 10,5 & 15.147 & 264,1 \\
São Geraldo & 58 & 15,3 & 21.281 & 272,5 \\
São João & 136 & 35,8 & 22.358 & 608,2 \\
Zona Rural & 20 & 5,3 & 12.462 & 160,5 \\
\hline TOTAL & 380 & 100,0 & 116.262 & 326,8 \\
\hline
\end{tabular}


A taxa de vítimas que procuraram tratamento no pronto-atendimento em relação à população por região de residência é muito mais alta no bairro São João que nos demais locais de Pouso Alegre, demonstrando que a facilidade de acesso é um efetivo fator para o aumento da demanda de serviços de saúde. As outras regiões da cidade, excetuando-se a zona rural, tiveram taxas com valores relativamente próximos, o que pode reforçar a hipótese de que a menor ou maior facilidade de acesso influenciaria na definição dos critérios usados pela população ao demandar os serviços de saúde.

\section{- Dia do evento na semana}

A tabela 7 nos mostra como foi a distribuição dos dias de ocorrência dos acidentes e violências que as vítimas procuraram o serviço estudado neste trabalho. É importante lembrar que se trata de informação auto-referida, porém pouco sujeita a viés pela ocorrência extremamente próxima ao atendimento.

Tabela 7 - Vítimas de causas externas de morbidade e mortalidade atendidas em serviço de atenção às urgências no municipio de Pouso Alegre, MG, fevereiro a junho de 2003 segundo dia da semana (n. ${ }^{\circ}$ e \%).

\begin{tabular}{lcc} 
DIA DA SEMANA & $\mathbf{N .}^{{ }^{\circ}}$ de pacientes & $\boldsymbol{\%}$ \\
\hline Domingo & 63 & $16,6 \%$ \\
Segunda-feira & 52 & $13,7 \%$ \\
Terça-feira & 54 & $14,2 \%$ \\
Quarta-feira & 48 & $12,6 \%$ \\
Quinta-feira & 44 & $11,6 \%$ \\
Sexta-feira & 54 & $14,2 \%$ \\
Sábado & 65 & $17,1 \%$ \\
\hline Total & $\mathbf{3 8 0}$ & $\mathbf{1 0 0 , 0 \%}$ \\
\hline
\end{tabular}

A maior parte dos agravos (47,9\%) aconteceu nos três dias do final de semana (sexta, sábado e domingo). Os dias de menor ocorrência foram os do meio da semana (quarta e quinta feira). Tal situação é semelhante àquela descrita pela literatura que mostra que as pessoas, no fim de semana, ao se dedicar a atividades de lazer, muitas vezes abusam do uso de bebidas alcoólicas e outras substâncias, além de terem uma exposição ampliada ao risco de acidentes (principalmente de trânsito) e violências, 
uma vez que a população se dirige a um maior número de atividades pelas ruas da cidade. Estes achados coincidem com os do trabalho de MESQUITA FILHO (1998) para o mesmo município e para acidentes de transporte em 1996 e os de ANDRADE (1998) para Londrina também para as mesmas causas. Nos estudos efetuados por MELLO JORGE (1980a; 1980b; 1981) sobre as mortes violentas na cidade de São Paulo também se encontrou uma ocorrência maior nos finais de semana. BAKER e cols. (1992) também mostram que a mortalidade por homicídios e lesões nãointencionais, tem um aumento de sua incidência entre sexta-feira e domingo, atingindo picos nos sábados.

A tabela 8 mostra que algumas das causas externas são as responsáveis por uma maior concentração de casos no fim de semana, entre elas, as agressões nas sextas, sábados e domingos e, as outras causas externas de traumatismos acidentais (principalmente contato com objetos cortantes e quedas) e os acidentes de transportes, mais presentes aos sábados. A exposição a forças mecânicas animadas tem sua maior ocorrência também nos finais de semana, apesar de apresentar uma distribuição homogenia e de pequena variabilidade. 
Tabela 8 - Vítimas de causas externas de morbidade e mortalidade atendidas em serviço de atenção às urgências no município de Pouso Alegre, MG, fevereiro a junho de 2003 segundo causa e dia da semana (n. $\left.{ }^{\circ}\right)$.

\begin{tabular}{|c|c|c|c|c|c|c|c|c|}
\hline \multirow{2}{*}{ CAUSA } & \multicolumn{7}{|c|}{ DIA DA SEMANA } & \multirow[b]{2}{*}{ Total } \\
\hline & Domingo & Segunda & Terça & Quarta & Quinta & Sexta & Sábado & \\
\hline Desconhecida & - & - & - & - & 1 & - & - & 1 \\
\hline Acidentes de Transporte & 7 & 3 & 8 & 9 & 6 & 7 & 12 & 52 \\
\hline Agressões & 11 & 4 & 7 & - & 3 & 8 & 8 & 41 \\
\hline Lesões Autoprovocadas & 1 & 2 & - & 2 & 1 & 2 & - & 8 \\
\hline $\begin{array}{l}\text { Outras C. Ext. de Lesões } \\
\text { Acidentais }\end{array}$ & 44 & 43 & 39 & 37 & 33 & 37 & 45 & 278 \\
\hline - Queda & 17 & 9 & 10 & 13 & 8 & 8 & 13 & 78 \\
\hline $\begin{array}{l}\text { - Exposição a forças } \\
\text { mecanicas inanimadas }\end{array}$ & 15 & 24 & 19 & 18 & 18 & 17 & 21 & 132 \\
\hline $\begin{array}{l}\text { o contato com objeto } \\
\text { cortante(vidro, faca, ferramenta) }\end{array}$ & 10 & 9 & 11 & 10 & 11 & 13 & 18 & 82 \\
\hline - impacto acidental & 4 & 13 & 7 & 6 & 6 & 4 & 2 & 42 \\
\hline - contato com máquinas & 1 & 2 & 1 & 2 & 1 & 0 & 1 & 8 \\
\hline $\begin{array}{l}\text { - Exposição a forças } \\
\text { mecânicas animadas }\end{array}$ & 10 & 9 & 8 & 5 & 7 & 9 & 10 & 58 \\
\hline $\begin{array}{l}\circ \text { colisāo entre duas } \\
\text { pessoas }\end{array}$ & 1 & - & - & 1 & - & 1 & - & 3 \\
\hline $\begin{array}{l}\text { - mordedura ou golpe } \\
\text { provocado por cão }\end{array}$ & 7 & 6 & 8 & 3 & 6 & 8 & 8 & 46 \\
\hline $\begin{array}{c}\text { o mordedura ou golpe } \\
\text { provocados por outros animais }\end{array}$ & 2 & 3 & - & 1 & 1 & - & 2 & 9 \\
\hline $\begin{array}{l}\text { - Contato com fonte de } \\
\text { calor }\end{array}$ & 2 & - & 1 & - & - & - & $l$ & 4 \\
\hline - Outras & - & $I$ & 1 & - & - & 3 & 1 & 6 \\
\hline Total & 63 & 52 & 54 & 48 & 44 & 54 & 65 & 380 \\
\hline
\end{tabular}

- Dia de semana de entrada no serviço

A data que o paciente procurou o serviço em $89,5 \%$ dos casos coincidiu com a data do evento. Em trinta e quatro indivíduos esta data apresentou diferenças. Nestes casos, o que geralmente havia era uma ocorrência no período noturno ou no final da tarde em que a pessoa deixava para procurar atendimento no dia seguinte. Geralmente tratavam-se de lesões ocasionadas por contato com cães e em algumas vezes, situaçč es provocadas por agressão ou lesões autoprovocadas. Outros tipos de situações foram as que determinados indivíduos sofriam acidentes ou violências em horários próximos das 24 horas e chegavam ao serviço para serem atendidos em horários imediatamente após estas, ou seja, no outro dia. 
A maior concentração de entradas de individuos ocorreu aos sábados e domingos e numa concentração um pouco menor nas segundas, terças e sextas feiras, sendo os dias de menor movimento as quartas e quintas-feiras. Tais dados se assemelham com a literatura citada no item anterior.

\section{- Horário de ocorrência}

Os horários de ocorrência de problemas às vitimas das causas externas de morbidade e mortalidade podem ser pode ser visto na tabela 9:

Tabela 9 - Vítimas de causas externas de morbidade e mortalidade atendidas em serviço de atenção às urgências no município de Pouso Alegre, MG, fevereiro a junho de 2003, segundo horário de ocorrência (n. ${ }^{\circ} \mathrm{e} \%$ ).

\begin{tabular}{lcc}
\hline HORARIO & N. $^{{ }^{\prime}}$ & $\%$ \\
\hline De zero h às $559 \mathrm{~h}$ & 13 & $3,4 \%$ \\
$6: 00 \mathrm{~h}$ às $11: 59 \mathrm{~h}$ & 95 & $25,0 \%$ \\
12:00 h às $17: 59 \mathrm{~h}$ & 198 & $52,1 \%$ \\
18:00 h às $23: 59 \mathrm{~h}$ & 73 & $19,2 \%$ \\
Desconhecido & 1 & $0,3 \%$ \\
\hline Total & $\mathbf{3 8 0}$ & $\mathbf{1 0 0 , 0 \%}$ \\
\hline
\end{tabular}

A maioria das ocorrèncias de agravos à saúde registrados $(77,1 \%)$ aconteceu em período diurno (entre seis e dezoito horas). Os horários mais comuns para os eventos ocasionados pelas causas externas foram aqueles entre o meio-dia e as 17:59 horas: $52,1 \%$ das ocorrências. Estes resultados foram divergentes dos de ANDRADE (1998) e dos de MESQUITA FILHO (1998) ambos estudando vitimas de acidentes de transporte, que encontraram uma ocorrência maior entre 18:00 e 23:59 h. Em segundo lugar as ocorrências surgem mais de 06:00 às 11:59 h com exceção da terça feira e domingo que é das 18:00 às 23:59 h. Em todos os dias da semana, o intervalo de 12:00 às 17:59 h foi o horário de maior ocorrência. A diferença entre os estudos citados e o que foi encontrado nesta investigação talvez se deva ao fato da maior concentração de agravos atendidos seja oriunda de outras causas externas de traumatismos acidentais, que envolvem muitos acidentes domésticos e os que acontecem em ambiente de trabalho, de maior probabilidade de ocorrência em periodo diurno. A tabela 10 mostra o horário de ocorrência das diversas causas 
externas. Agressões tiveram o mesmo número de ocorrências no período da tarde e da noite, e apresentaram, proporcionalmente, um nủmero maior de ocorrências de madrugada que as demais causas. Já, os acidentes de transporte, no período noturno ocorreram em maior quantidade que na manhã mantendo, entretanto, o periodo das 12:00 às 17:59 $\mathrm{h}$ como o principal. As outras causas externas de traumatismo acidentais, em todas as suas classificações levantadas neste estudo, ocorreram principalmente no periodo entre o meio dia e as 17:59 h, dentro do padrão geral.

Tabela 10 - Vítimas de causas externas de morbidade e mortalidade atendidas em serviço de atenção às urgências no município de Pouso Alegre, MG, fevereiro a junho de 2003, segundo causa e horário de ocorrência $\left(\mathrm{n}^{\circ}{ }^{\circ}\right.$.

\begin{tabular}{|c|c|c|c|c|c|c|}
\hline \multirow[b]{2}{*}{ CAUSA } & \multicolumn{5}{|c|}{ HORÁRIO } & \multirow[b]{2}{*}{ Total } \\
\hline & $\begin{array}{l}0: 00 \text { às } \\
5: 59 \mathrm{~h}\end{array}$ & $\begin{array}{l}6: 00 \text { às } \\
11: 59 \mathrm{~h}\end{array}$ & $\begin{array}{l}12: 00 \text { às } \\
17: 59 \mathrm{~h}\end{array}$ & $\begin{array}{l}18: 00 \text { às } \\
23: 59 \mathrm{~h}\end{array}$ & $\begin{array}{l}\text { Desco- } \\
\text { nhecido }\end{array}$ & \\
\hline Desconhecida & - & - & 1 & - & - & 1 \\
\hline Acidentes de Transporte & 1 & 11 & 23 & 16 & 1 & 52 \\
\hline Agressões & 5 & 2 & 17 & 17 & - & 41 \\
\hline Lesões Autoprovocadas & 1 & 5 & 1 & 1 & - & 8 \\
\hline Outras causas externas de & & & & & & \\
\hline traumatismos acidentais & 6 & 77 & 156 & 39 & - & 278 \\
\hline $\begin{array}{l}\text { - Queda } \\
\text { - Exposição a forças }\end{array}$ & 2 & 25 & 38 & 13 & - & 78 \\
\hline $\begin{array}{l}\text { mecânicas inanimadas } \\
\circ \quad \text { contato com objeto }\end{array}$ & 3 & 31 & 81 & 17 & - & 132 \\
\hline cortante(vidro, faca, ferramenta) & 3 & 18 & 48 & 13 & - & 82 \\
\hline - impacto acidental & - & 11 & 28 & 3 & - & 42 \\
\hline $\begin{array}{l}\text { o contato com máquinas } \\
\text { - Exposição a forças }\end{array}$ & - & 2 & 5 & 1 & - & 8 \\
\hline mecânicas animadas & 1 & 16 & 33 & 8 & - & 58 \\
\hline $\begin{array}{l}\text { - colisão entre duas pessoas } \\
\text { - mordedura ou golpe }\end{array}$ & - & 2 & 1 & - & - & 3 \\
\hline $\begin{array}{l}\text { provocado por cảo } \\
\text { o mordedura ou golpe }\end{array}$ & - & 12 & 28 & 6 & - & 46 \\
\hline provocados por outros animais & 1 & 2 & 4 & 2 & - & 9 \\
\hline $\begin{array}{l}\text { - Contato com fonte de } \\
\text { calor }\end{array}$ & - & 1 & 1 & 2 & - & 4 \\
\hline - Outras & - & 3 & 3 & - & - & 6 \\
\hline Total & 13 & 95 & 198 & 73 & 1 & 380 \\
\hline
\end{tabular}

Os horários foram relatados pelas próprias vítimas ou por seus acompanhantes durante o preenchimento da ficha de notificação, estando, portanto, 
sujeitos a viéses, pois o dado obtido de forma secundária não apresenta a mesma confiabilidade daquele diretamente observado pelo pesquisador.

\section{- Horário de entrada no serviço}

O horário de entrada no PA foi semelhante ao do momento de ocorrência da causa externa. A maioria dos pacientes $(51,8 \%)$ acorreu ao serviço no período entre 12:00 e 17:59 h, vindo a seguir de 6:00 às 11:59 h (com 23,2\%); de 18:00 às 23:59 $(22,9 \%)$ e por último entre 0:00 e $6: 00$ horas $(2,1 \%)$. Esse fato ocorreu porque o acesso para o serviço é fácil e poucos pacientes tiveram de aguardar um tempo mais dilatado para seu atendimento. Quando o horário divergiu, pode ter acontecido o não deslocamento ao Pronto--atendimento, por parte de pacientes que preferiram aguardar mais um pouco em casa, por acharem que não havia necessidade de socorro imediato a suas lesōes e que posteriormente mudaram de idéia. Uma outra razão para acontecer esta pequena divergência de números é que pacientes que foram vitimas de acidentes e violências nos periodos limítrofes de duas faixas de horário, podem ter, no momento do deslocamento, mudado de uma para outra faixa.

\section{- Local de ocorrência}

$\mathrm{Na}$ tabela 11 verifica-se que o principal local de ocorrência das causas externas foram as residências das vitimas. Excetuando-se os acidentes de transporte, é justamente no lugar em que as pessoas se sentem em maior segurança que ocorreram $40,3 \%$ dos problemas vinculados às causas externas. Tal fato nos leva a atentar para a importância tanto dos acidentes domésticos como problema de saúde pública, bem como para as agressões, que ocorrem em grande número em casa. Se imaginarmos que parte importante das agressões, principalmente aquelas feitas às crianças e às mulheres e aquelas que não são reveladas, acontecem nos lares das vítimas (CAVALCANTI, 1999; DESLANDES, 1994, NCIPC,2001, NCIPC, 1996), deve-se atentar para a importância deste local para o desenvolvimento de ações de prevenção e combate.

As ruas também foram um importante local de ocorrência dos problemas estudados $(27,1 \%)$. Esta situação pode ser esperada pois os riscos inerentes às violências e acidentes fazem parte do dia-dia das ruas (trânsito problemático, crimes, 
infra-estrutura urbana caótica, consumo de drogas ilícitas e de bebidas alcoólicas, prostituição, exploração de crianças, etc).

Tabela 11 - Causas e locais de ocorrência de agravos à saúde provocados por causas externas em individuos atendidos em serviço de atenção às urgências no município de Pouso Alegre, MG, fevereiro a junho de 2003.

\begin{tabular}{|c|c|c|c|c|c|c|}
\hline \multirow[b]{2}{*}{$\begin{array}{l}\text { Local de } \\
\text { Ocorrência }\end{array}$} & \multicolumn{5}{|c|}{ CAUSA } & \multirow[b]{2}{*}{ Total } \\
\hline & $\begin{array}{l}\text { Desco- } \\
\text { nhecida }\end{array}$ & $\begin{array}{l}\text { Acidente } \\
\text { transporte }\end{array}$ & $\begin{array}{l}\text { Agres- } \\
\text { sões }\end{array}$ & $\begin{array}{l}\text { Auto-provo- } \\
\text { cadas }\end{array}$ & $\begin{array}{c}\text { Outras } \\
\text { causas } \\
\text { extemas }\end{array}$ & \\
\hline $\begin{array}{l}\text { Área de comércio } \\
\text { e serviços } \\
\text { Área de industria }\end{array}$ & - & - & - & - & 3 & 3 \\
\hline $\begin{array}{l}\text { ou em construção } \\
\text { Área para prática }\end{array}$ & - & - & 1 & - & - & 1 \\
\hline de esportes & - & 1 & 3 & - & 11 & 15 \\
\hline Escola & - & - & 1 & - & 16 & 17 \\
\hline Estrada & - & 4 & - & - & 1 & 5 \\
\hline Local trabalho & - & 1 & - & - & 47 & 48 \\
\hline Outro & - & - & 4 & 1 & 12 & 17 \\
\hline Residência & 1 & - & 18 & 7 & 126 & 152 \\
\hline ?ua & - & 46 & 14 & - & 42 & 102 \\
\hline Zona rural & - & - & - & - & 20 & 20 \\
\hline Total & 1 & 52 & 41 & 8 & 278 & 380 \\
\hline
\end{tabular}

Destacou-se, também, a importância do local de trabalho no surgimento das consequiências das causas externas: $12,6 \%$ destas aí aconteceram, ressaltando-se a problemática que envolve a saúde do trabalhador e a importância do aperfeiçoamento da vigilância das lesões ocupacionais. As vitimas dos agravos nestes locais estiveram no serviço de saúde para atendimento às suas lesões, sem demonstrarem quaisquer consciência de que tinham sido vitimas de um acidente de trabalho. Este fato contribui para a subnotificação do problema, bem como, para que não se tomem medidas de proteção àqueles trabalhadores sob risco. Além disso, é bom recordar que os agravos desta natureza não são exclusivos do ambiente de trabalho (os acidentes típicos) mas também devem ser lembrados os de trajeto, o que amplia a possibilidade da subnotificação de importante parcela dos mesmos. MACHADO \& GOMEZ (1994) discutem o registro de acidentes do trabalho informando que $O$ aprofundamento da informação sobre eles "requer estudos interdisciplinares especificos; práticas de vigilância com busca ativa de casos; identificação e implementação de serviços de referência; análises epidemiológicas". 


\subsection{5 -Detalhando as causas externas de morbidade e mortalidade notificadas}

\section{- Outras causas externas de traumatismos acidentais}

Esta seção, dentro do capitulo das causas externas, é das que apresenta uma das maiores variedades de eventos. Nela estão classificadas quedas nas mais diversas situações, intoxicações, problemas causados por animais, objetos cortantes, impacto acidental (objetos contundentes), entre outras. Abrange um amplo espectro de acidentes domésticos, da esfera do trabalho, da prática de lazer e esportes, afogamentos, inalações e envenenamentos acidentais, queimaduras, etc. Foi a categoria que mais vitimas teve (278), sendo responsável por $73,2 \%$ das causas externas registradas. Entretanto, são poucos os estudos feitos no Brasil que as abordam. Tendo em vista trabalhos de outros países (NCIPC, 2001) que apontam para a relevância do tema, pode-se formular a hipótese de que a real dimensão deste problema é muito maior do que realmente se conhece e que a organização de sistemas de informação em pronto-socorros é fundamental para o seu equacionamento enquanto importante causa de morbimortalidade.

$\mathrm{Na}$ figura 7 verifica-se a distribuição destas causas entre os 277 agravos classificados nas "outras causas externas de traumatismos acidentais":

- $29,5 \%$ acidentes por contato com objetos cortantes (vidro, facas, tesouras, agulha, enxada, etc.);

- $28,1 \%$ quedas;

- $19,8 \%$ mordedura ou golpe provocado por animais (principalmente mordidas de cães);

- $15,1 \%$ acidentes por impacto acidental com objetos contundentes (pau, muro, pedra, tijolo, etc.)

- $7,6 \%$ outras (contato com máquinas, colisão entre duas pessoas, queimaduras, intoxicações acidentais, contato com fonte de calor, etc.). 
Figura 7 - Freqüência das vítimas de outras causas externas de traumatismos, segundo tipo de causa externa, que foram atendidas em serviço de atenção às urgências no município de Pouso Alegre, MG, fevereiro a junho de 2003 (\%).

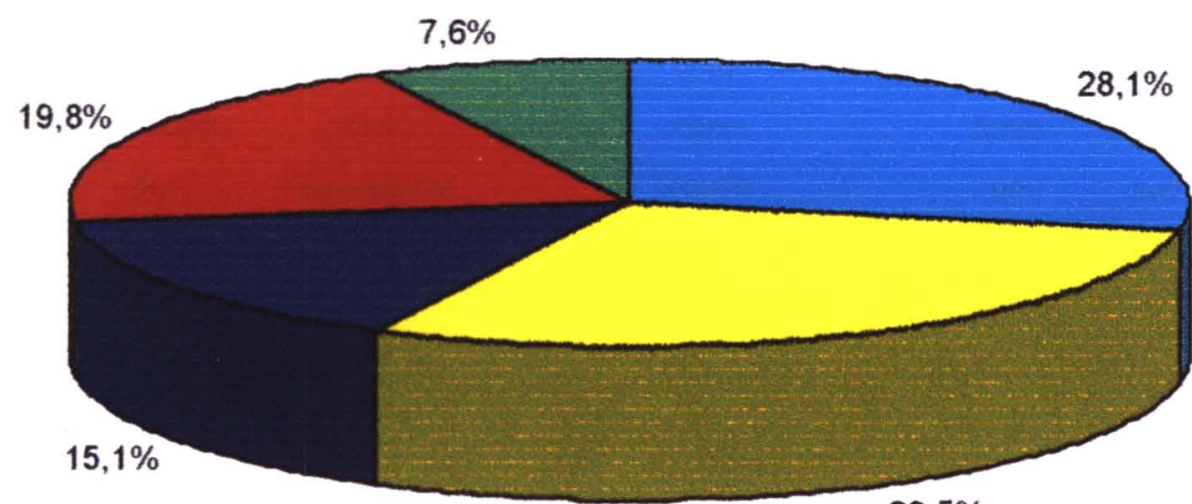

$29,5 \%$

$\square$ Queda $\square$ Objeto cortante $\square$ Impacto $\square$ Contato com animais $\square$ Outras

As lesões provocadas por objetos cortantes, quedas, objetos contundentes e contato com animais ocorrem de forma majoritária em residências $(42,1 \%$ como se verifica na tabela 11). Outra locação de importância foram locais de trabalho $(17,0 \%)$. Essas constatações reforçam a necessidade de estudos sobre esse tema com vistas a se implantar ações integrais de saúde para esse tipo de agravo e de se tratar de forma adequada os riscos situados na casa e ambientes de trabalho das suas possíveis vítimas.

A tabela 12 vai mostra a ocorrência de outras causas externas de traumatismos acidentais de acordo com as diversas faixas etárias. 
Tabela 12 - Vítimas de outras causas externas de traumatismos acidentais atendidas em serviço de atenção às urgências no município de Pouso Alegre, MG, fevereiro a junho de 2003, segundo causa e faixa etária (N. $\left.{ }^{\circ}\right)$

\begin{tabular}{|c|c|c|c|c|c|c|c|c|c|}
\hline \multirow[b]{2}{*}{$\begin{array}{l}\text { Faixa } \\
\text { Etária } \\
\text { (Anos) }\end{array}$} & \multicolumn{8}{|c|}{ OUTRAS CAUSAS EXTERNAS } & \multirow[b]{2}{*}{ Total } \\
\hline & $\begin{array}{c}\text { Mordedura } \\
\text { ou golpe } \\
\text { provocado } \\
\text { por } \\
\text { animais }\end{array}$ & $\begin{array}{c}\text { Impacto } \\
\text { acidental - } \\
\text { objeto } \\
\text { contundente }\end{array}$ & $\begin{array}{l}\text { Colisão } \\
\text { entre } 2 \\
\text { pessoas }\end{array}$ & $\begin{array}{l}\text { Contato } \\
\text { com } \\
\text { objeto } \\
\text { cortante }\end{array}$ & Queda & $\begin{array}{l}\text { Contato } \\
\text { com } \\
\text { fonte } \\
\text { de } \\
\text { calor }\end{array}$ & $\begin{array}{l}\text { Contato } \\
\text { com } \\
\text { máqui- } \\
\text { nas }\end{array}$ & Outras & \\
\hline $0 \mathrm{a} 4$ & 12 & 3 & 1 & 5 & 15 & 2 & - & 1 & 39 \\
\hline 5 a 9 & 9 & 10 & - & 6 & 16 & - & - & - & 41 \\
\hline 10 a 14 & 7 & - & 1 & 8 & 6 & - & - & 1 & 23 \\
\hline 15 a 19 & 3 & 2 & - & 8 & 3 & - & 1 & - & 17 \\
\hline 20 a 29 & 8 & 10 & - & 21 & 10 & 1 & 2 & 2 & 54 \\
\hline 30 a 39 & 2 & 9 & 1 & 15 & 1 & - & 3 & 2 & 36 \\
\hline 40 a 59 & 9 & 4 & - & 14 & 12 & - & 2 & - & 41 \\
\hline $60 e+$ & 5 & 2 & - & 4 & 9 & 1 & - & - & 21 \\
\hline Ignorado & - & 2 & - & 1 & 3 & - & - & - & 6 \\
\hline Total & 55 & 42 & 3 & 82 & 78 & 4 & 8 & 6 & 278 \\
\hline
\end{tabular}

A faixa etária de zero a nove anos foi a mais afetada por estas causas externas com $28,8 \%$ dos casos. É um problema que repercute sobre as populações mais jovens pois $62,6 \%$ de suas ocorrências foi entre menores de trinta anos. Das vitimas, $68,0 \%$ era do sexo masculino, com uma razão homem/mulher de $2,1: 1,0$, o que é menor do que em outras categorias de causas externas. Os indivíduos que sofreram agravos relativos a contato ou mordida de animais apresentaram também uma razão de valores menores: $1,5: 1,0$. Verificou-se que 92,6\% destes corresponderam a acidentes com animais domésticos (85,2\% cães e $7,4 \%$ gatos). Por acontecerem no domicilio os riscos podem ser semelhantes para as pessoas de ambos os sexos. 


\section{- Acidentes de transporte}

A figura 8 mostra indivíduos que foram vítimas de acidentes de transporte e que foram atendidos no serviço municipal.

Figura 8 - Freqüência de Vítimas de acidentes de transporte atendidas em serviço de atenção às urgências no município de Pouso Alegre, MG, fevereiro a junho de 2003 $(\%)$.

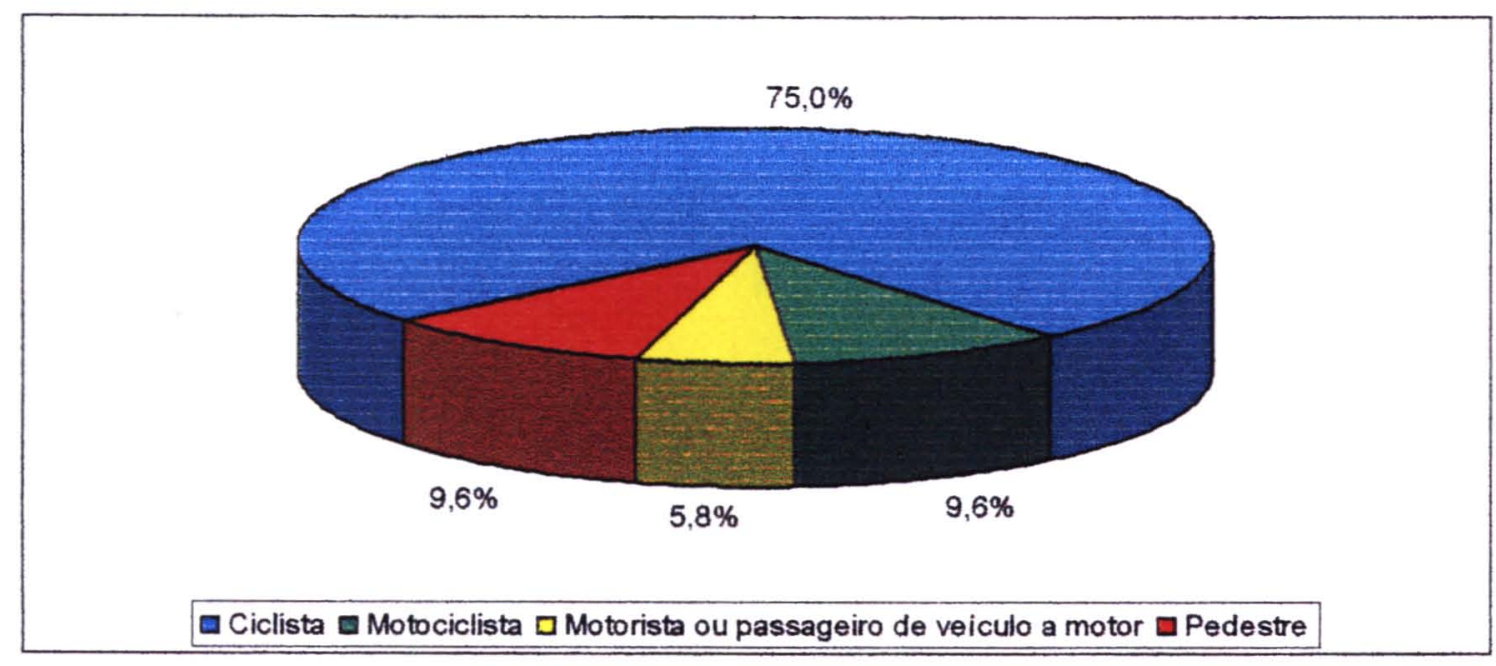

A maioria das pessoas que sofreram algum tipo de acidente de transporte era ciclista $(75,0 \%)$. Destes $74,4 \%$ foram vítimas de quedas e $25,6 \%$ de colisões. Nenhum deles portava qualquer tipo de equipamento de segurança, como por exemplo, capacete. Dos ciclistas que sofreram colisão, cinco colidiram com objetos fixos, três com automóveis, um com uma outra bicicleta e um com um caminhão. BAKER, LI, FOWLER \& DANNENBERG (2002) informam que nos EUA ocorreram 1.767.000 quedas deste tipo de veículo no ano de 1990. Foram tratados em pronto-socorros neste cerca de 580.000 ciclistas sendo dois terços destes menores de quinze anos de idade. O local de ocorrência mais comum era nas ruas (34\%), sendo que, no entanto, os acidentes que acontecem em casa constituem uma importante parcela (28\%). Naquele país também a subnotificação foi importante pois $32 \%$ destes eventos aconteceram em local ignorado.

Motociclistas e pedestres vieram a seguir com $9,6 \%$ cada um e motoristas e passageiros de automóvel, caminhonete ou caminhão 5,8\%. 
A figura 9 mostra que os acidentados de transporte atendidos no prontoatendimento em $63,5 \%$ das ocasiões foram vítimas de quedas de bicicleta, em $26,9 \%$ de colisões e em $9,6 \%$ de atropelamentos.

Figura 9 - Tipos de acidentes de transporte em que as vítimas foram atendidas em serviço de atenção às urgências no município de Pouso Alegre, MG, fevereiro a junho de 2003 (\%).

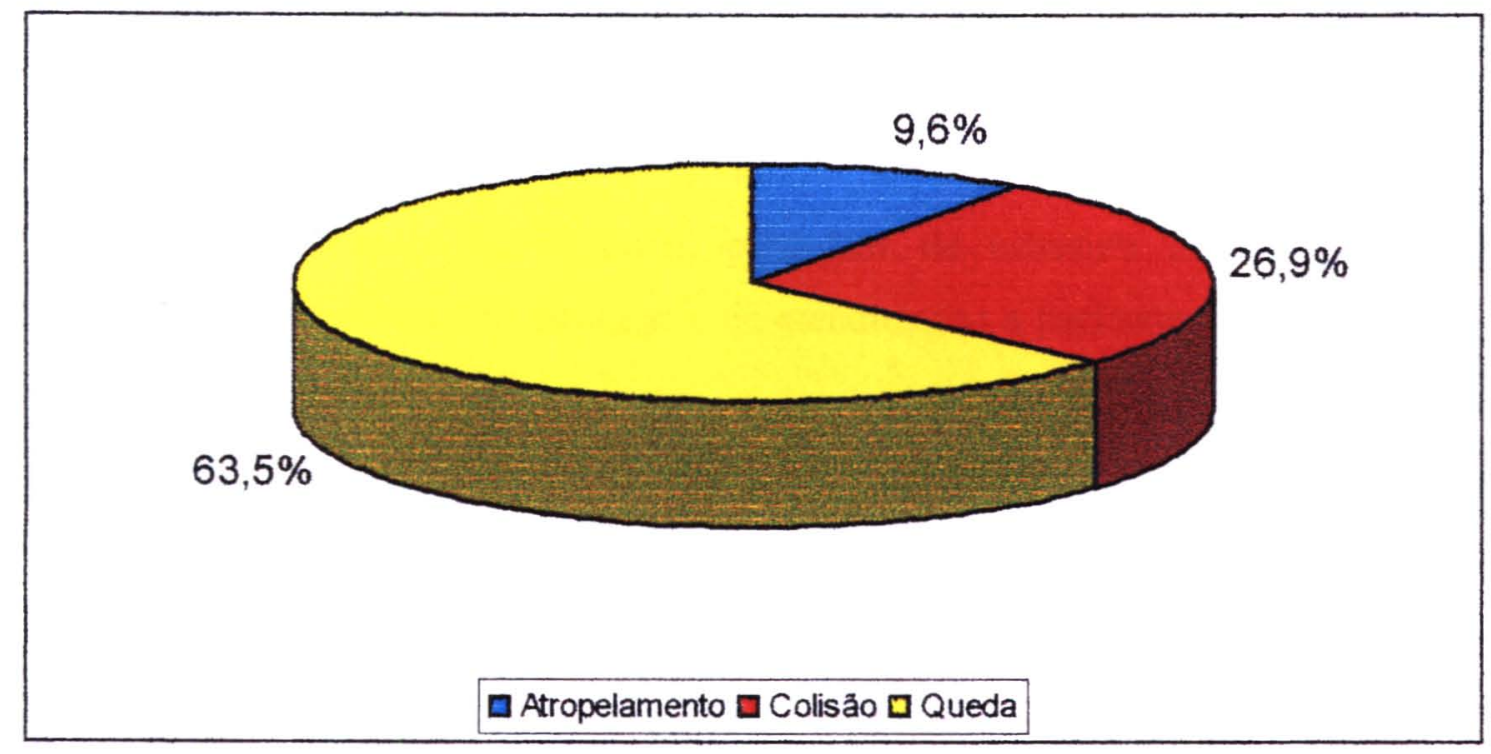

Estes achados são divergentes daqueles encontrados na literatura que informa que os acidentes de transporte mais comuns seriam os atropelamentos, tanto naqueles referentes à mortalidade (LAURENTI e cols., 1972; MELLO JORGE 1980a, 1980b; 1981, 1982, 1988, 1997; MELLO JORGE \& MARQUES, 1986; MELLO JORGE \& LATORRE, 1994; FISHMAN, AGUIAR \& MINOTTO, 1990; MINAYO, 1994; MINAYO \& SOUZA, 1993; KLEIN, 1994) como nos de morbidade (OTT e cols., 1993; FRIEDMAN e cols., 1991, DESLANDES, 1999; DESLANDES \& SILVA 2000). As quedas predominaram, principalmente, porque o maior número de atendimentos, no caso dos acidentes de transporte, teve como pacientes ciclistas e que a bicicleta se trata de um meio de locomoção muito utilizado no município em estudo, em virtude das suas características topográficas de pouco relevo, que facilitam seu uso. Em estudos norte-americanos foram apresentados para 1999 os seguintes números:

- vítimas de acidentes não-fatais com veículos a motor - três milhões; 
- vítimas de acidentes não-fatais com bicicletas - $500 \mathrm{mil}$;

- $\quad$ pedestres vítimas de acidentes não-fatais - 85 mil (NCIPC, 2001).

Estes resultados ressaltam a importância dos acidentes com bicicleta como um dos que mais causam vítimas não-fatais. A tabela 13 mostra que 50,0\% de todos acidentes registrados são quedas de bicicleta que ocasionaram vítimas com idade inferior a vinte anos.

Os resultados encontrados, para os acidentes de transporte, podem também ter apresentado divergências com outros estudos em virtude do serviço trabalhado não ter captado, com já foi informado, as vítimas portadoras de agravos de maior gravidade, já que nestes casos os indivíduos eram encaminhados diretamente para os serviços do hospital universitário, possuidor de estrutura capacitada a cobrir demandas de internações, cirurgias e de atendimento a pacientes que necessitem de cuidados intensivos.

A tabela 13 especifica a proporção de acidentes por faixa etária. A maior parte destes ocorreu de 10 a 39 anos com 76,9\% das ocorrências. As quedas de bicicleta aconteceram mais nesta faixa enquanto as colisões entre 15 e 39 anos. Mais de $90,0 \%$ dos acidentes de transporte acontecem antes dos quarenta anos. 
Tabela 13 - Tipos de acidentes de transporte e faixa etária de pacientes atendidos por estes agravos em serviço de urgências em Pouso Alegre, de fevereiro a junho de 2003.

\begin{tabular}{|c|c|c|c|c|c|c|c|c|}
\hline \multirow[b]{2}{*}{$\begin{array}{l}\text { FAIXA } \\
\text { ETÁRIA }\end{array}$} & \multicolumn{6}{|c|}{ CAUSA } & \multirow[b]{2}{*}{ Total } & \multirow[b]{2}{*}{$\%$} \\
\hline & $\begin{array}{c}\text { Atropelamento } \\
\text { (pedestre) }\end{array}$ & $\%$ & $\begin{array}{c}\text { Colisão } \\
\text { de } \\
\text { veículos }\end{array}$ & $\%$ & $\begin{array}{c}\text { Queda de } \\
\text { bicicleta }\end{array}$ & $\%$ & & \\
\hline 0 a 9 & - & - & - & - & 13 & 25,0 & 13 & 25,0 \\
\hline menos de 1 & - & - & - & - & 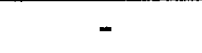 & - & - & - \\
\hline 1 a 4 & - & - & - & - & 2 & 3,8 & 2 & 3,8 \\
\hline 5 a 9 & - & - & - & - & 3 & 5,8 & 3 & 5,8 \\
\hline 10 a 19 & 1 & 1,9 & 3 & 5,8 & 13 & 25,0 & 17 & 32,7 \\
\hline 10 a 14 & 1 & 1,9 & - & - & 8 & 15,4 & 9 & 17,3 \\
\hline 15 a 19 & - & - & 3 & 5,8 & 5 & 9,6 & 8 & 15,4 \\
\hline 20 a 39. & 3 & 5,8 & 9 & 17,3 & 11 & 21,2 & 23 & 44,2 \\
\hline 20 a 29 & 2 & 3,8 & 3 & 5,8 & 5 & 9,6 & 10 & 19,2 \\
\hline 30 a 39 & 1 & 1,9 & 6 & 11,5 & 6 & 11,5 & 13 & 25,0 \\
\hline mais de 40 & 1 & 1,9 & 2 & 3,8 & 2 & 3,8 & 5 & 9,6 \\
\hline 40 a 49 & - & - & - & - & 2 & 3,8 & 2 & 3,8 \\
\hline 50 a 59 & - & - & 1 & 1,9 & - & - & 1 & 1,9 \\
\hline 60 e mais & 1 & 1,9 & 1 & 1,9 & - & - & 2 & 3,8 \\
\hline Desconhecida & - & - & - & - & 2 & 3,8 & 2 & 3,8 \\
\hline Total & 5 & 9,6 & 14 & 26,9 & 33 & 63,5 & 52 & 100,0 \\
\hline
\end{tabular}

A maioria dos acidentados era do sexo masculino numa razão de $7,7: 1,0$. Esta foi muito superior a razões encontradas tanto em estudos de morbidade como de mortalidade (MESQUITA FILHO, 1998; ANDRADE,1998), bem como nos estudos de mortalidade (MELLO JORGE, 1980a , 1980b, 1981, 1982; MELLO JORGE e cols, 1997; KLEIN, 1994; OTT, 1993; FRIEDMAN e cols, 1991; DESLANDES, 1999) .

Apenas cinco dos pacientes acidentados relataram uso de equipamento de segurança: dois motociclistas usavam capacete e dois ocupantes de veículo a motor usavam cinto de segurança.

\section{- $\quad$ Agressões}

A tabela 14 mostra a situação das agressões por faixa etária: 
Tabela 14 - Tipos de agressões e faixa etária de pacientes atendidos por estes agravos em serviço de urgências em Pouso Alegre, de fevereiro a junho de 2003.

\begin{tabular}{|c|c|c|c|c|c|c|}
\hline \multirow[b]{2}{*}{$\begin{array}{l}\text { FAIXA } \\
\text { ETÁRIA }\end{array}$} & \multicolumn{4}{|c|}{ CAUSA } & \multirow[b]{2}{*}{ TOTAL } & \multirow[b]{2}{*}{$\%$} \\
\hline & $\begin{array}{l}\text { Obj. cortante } \\
\text { ou penetrante }\end{array}$ & $\begin{array}{c}\text { Obj. } \\
\text { contundente }\end{array}$ & $\begin{array}{c}\text { Força } \\
\text { corporal }\end{array}$ & Outra & & \\
\hline $0 a 9$ & - & 2 & - & - & 2 & 4,9 \\
\hline menos de 1 & - & - & - & - & - & - \\
\hline 1 a 4 & - & 1 & - & - & 1 & 2,4 \\
\hline 5 a 9 & - & 1 & - & - & 1 & 2,4 \\
\hline 10 a 19 & 2 & 1 & 2 & - & 5 & 12,2 \\
\hline 10 a 14 & 1 & - & - & - & 1 & 2,4 \\
\hline 15 a 19 & 1 & 1 & 2 & - & 4 & 9,8 \\
\hline 20 a 39 & 6 & 5 & 7 & 1 & 19 & 46,3 \\
\hline 20 a 29 & 4 & 2 & 5 & 1 & 12 & 29,3 \\
\hline 30 a 39 & 2 & 3 & 2 & - & 7 & 17,1 \\
\hline mais de 40 & 6 & 4 & 4 & - & 14 & 34,1 \\
\hline 40 a 49 & 6 & 2 & 2 & - & 10 & 24,4 \\
\hline 50 a 59 & - & 1 & 2 & - & 3 & 7,3 \\
\hline 60 e mais & - & 1 & - & - & 1 & 2,4 \\
\hline Desconhecida & - & 1 & - & - & 1 & 2,4 \\
\hline Total & 14 & 13 & 13 & 1 & 41 & 100,0 \\
\hline
\end{tabular}

A terceira mais importante causa de morbidade por causas externas atendida no serviço estudado foram as agressões. Houve um total de 41 casos sendo $34,1 \%$ agressões feitas com o uso de força corporal, $31,7 \%$ com objeto cortante, $31,7 \%$ através de objeto contundente e 2,4\% utilizando outra maneira (água quente). Entre os indivíduos agredidos $68,3 \%$ eram do sexo masculino e $31,7 \%$ do feminino. Apenas na faixa etária entre 40 e 44 anos houve um número de vítimas femininas superior às masculinas. Destes pacientes, 63,4\% tinham menos de quarenta anos de idade, sendo que entre 20 e 39 anos se concentraram $46,3 \%$ das vítimas. O tópico das agressões é um dos de maior possibilidade de ser subnotificado por razões já discutidas.

\section{- Outras causas externas}

A tabela 4 mostra que aconteceram $2,1 \%$ de agravos autoprovocados (oito indivíduos), $0,3 \%$ outros agravos (um paciente) e um caso desconhecido $(0,3 \%)$. Apesar dos suicidios serem importantes causas de mortalidade por causas externas, 
no conjunto dos atendimentos estudados lesões autoprovocadas apresentaram uma importância relativa em termos numéricos, menor do que outras causas. Entretanto, pela gravidade que as lesões podem vir a adquirir, pela maior possibilidade de provocar óbitos, pela necessidade destes casos terem um tratamento hospitalar é provável que a maior parte dos casos tenha sido atendida no serviço de emergências. Também, como já foi visto anteriormente, a subnotificação pode atingir altos patamares nestes agravos.

\subsubsection{Lesões, envenenamentos e algumas outras conseqüências de causas externas notificadas e a localização das lesões por segmento corpóreo.}

Além do conhecimento da causa externa, conforme consta no capítulo XX da CID-10 (1995), é importante, para fins de notificação, que se faça a classificação do tipo de lesão conseqüente. Para tanto, no presente estudo, foi utilizado o capítulo XIX (de S00 a T98) daquela classificação: lesões, envenenamentos e algumas outras conseqüências de causas externas. Este capítulo tem como proposta codificar o tipo de traumatismo e sua localização anatômica.

Foram encontradas 575 lesões nos 380 pacientes estudados, sendo que nove deles tiveram um número desconhecido destas. A média foi de 1,5 lesões por indivíduo, com um desvio padrão de 2,2. O número médio de lesões encontrado em trabalho no mesmo município para acidentados de trânsito foi de 1,4 por indivíduo (MESQUITA FILHO, 1998). A mediana e a moda corresponderam a uma lesão. O número minimo de traumatismos encontrados por pessoa foi zero e o máximo foi de trinta e nove em uma única pessoa politraumatizada. A maioria delas $(75,3 \%)$ apresentou apenas uma lesão sendo que $91,9 \%$ dos pacientes tiveram entre zero e quatro. A tabela 15 mostra os tipos de lesões que ocorreram. A maioria das lesões atendidas eram ferimentos $(66,4 \%)$, seguidos dos traumatismos superficiais $(19,8 \%)$. Lesões do tipo traumatismos dos nervos e medula espinhal e por esmagamento não foram notificados. Verificou-se que $72,6 \%$ dos indivíduos atendidos eram portadores de ferimentos com a média de 1,4 por pessoa afetada. Os traumatismos superficiais que somaram 114 lesões atingindo 22,6\% dos indivíduos. Em cada paciente afetado por este tipo de traumatismo obteve-se uma média de 1,3 lesões per capita. Entorse, luxação e distensão foram as lesões que vieram a seguir provocando com 30 relatos e 
atingindo 27 indivíduos, com a média de 1,1. O estudo de LEBRÃO e cols. (1997), focado em morbidade hospitalar, mostra como maiores causas de internação as fraturas, vindo a seguir ferimentos e lesões traumáticas dos vasos sangüineos e lesões internas e intracranianas. Já no estudo de MESQUITA FILHO (1998), para acidentados de trânsito no mesmo municipio, atendidos em pronto-socorro, encontrou-se como agravos mais comuns lesões e traumatismos superficiais $(38,6 \%$ dos atendimentos), seguidos de ferimentos $(25,8 \%)$ e fraturas $(16,7 \%)$.

Tabela 15 - Número e proporção de lesões, envenenamentos e algumas outras consequiências de causas externas em pessoas que foram atendidas em serviço de atenção às urgências no município de Pouso Alegre, MG, fevereiro a junho de 2003 (Número total e percentagem).

\begin{tabular}{lcccc}
\hline \multirow{2}{*}{ Tipo } & \multicolumn{2}{c}{ LESȬES } & \multicolumn{2}{c}{ INDIVÍDUOS } \\
\cline { 2 - 5 } & $\mathbf{N .}^{\mathbf{0}}$ & $\mathbf{\%}$ & $\mathbf{N}^{{ }^{0}}$ & $\%$ \\
\hline Traumatismo superficial & 114 & 19,8 & 86 & 22,6 \\
Ferimentos & 382 & 66,4 & 276 & 72,6 \\
Fraturas & 7 & 1,2 & 7 & 1,8 \\
Luxação, entorse e distensão & 30 & 5,2 & 23 & 6,1 \\
Traumatismos dos vasos sanguíneos & 12 & 2,1 & 8 & 2,1 \\
Traumatismos dos tendões e músculos & 1 & 0,2 & 1 & 0,3 \\
Traumatismos dos órgãos internos & 5 & 0,9 & 3 & 0,8 \\
Corpo estranho & 10 & 1,7 & 10 & 2,6 \\
Queimaduras & 8 & 1,4 & 6 & 1,6 \\
Intoxicações & 5 & 0,9 & 5 & 1,3 \\
Outros e os não especificados & 1 & $\mathbf{0 , 2}$ & 1 & 0,3 \\
\hline Total & $\mathbf{5 7 5}$ & $\mathbf{1 0 0 , 0}$ & $\mathbf{3 8 0}$ & $\mathbf{1 0 0 , 0}$ \\
\hline
\end{tabular}

* Total de individuos, não reflete o somatório da coluna.

ANDRADE (1998), também estudando acidentes de transporte, encontrou $43,2 \%$ de lesões superficiais, $17,3 \%$ de ferimentos e $13,2 \%$ de fraturas como principais lesões.

A figura 10 mostra a proporção de tipos de lesão por faixa etária. Os ferimentos foram predominantes em todas as faixas etárias, vindo a seguir os traumatismos superficiais. Nas idades entre zero e quatro anos os traumatismos de órgãos internos apresentaram uma importância relativa superior à das outras idades. O mesmo ocorreu com luxações, entorses e distensões entre quinze e dezenove anos e nas vítimas de faixa etária indeterminada. Queimaduras tiveram relativa 
importância abaixo dos quatro anos e acima dos sessenta e os traumatismos de vasos sangüíneos concentraram sua ocorrência dos 35 aos 39 anos.

Em todos os tipos de traumas houve um predomínio de pacientes de sexo masculino: $79,7 \%$ das lesões atingiram aos homens contra $20,3 \%$ às mulheres, numa razão de $3,9: 1,0$.

Figura 10 - Proporção de lesões apresentadas por faixa etária em pacientes atendidos em serviço de atenção às urgências no município de Pouso Alegre, MG, fevereiro a junho de 2003

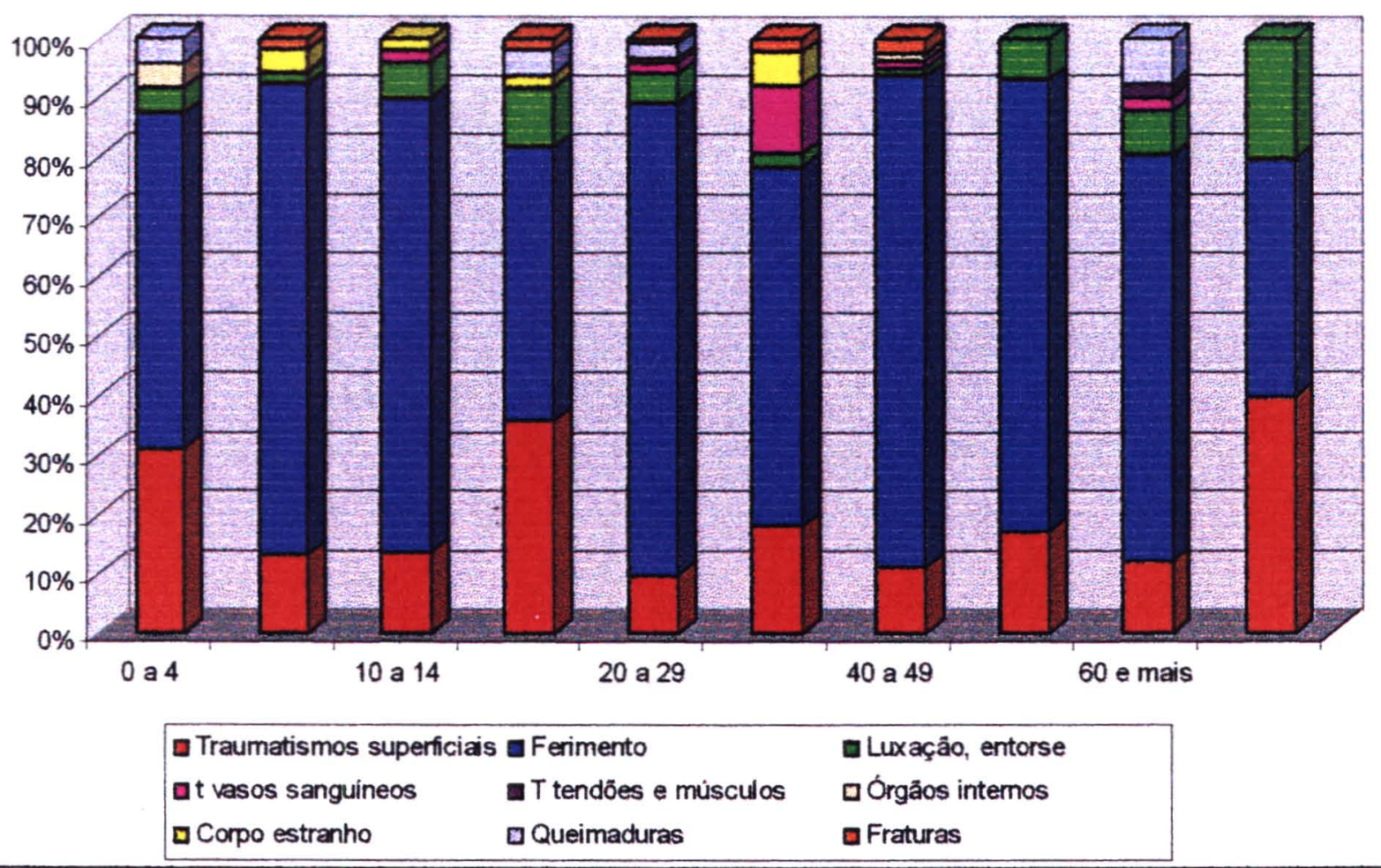

A relação entre os tipos de lesões e as causas externas que as ocasionaram é o que mostra a tabela 16. A lesão mais provocada por todos os tipos de causas externas foi representada pelos ferimentos. Os traumatismos superficiais ocuparam a segunda colocação entre as principais formas de lesão entre praticamente todas as causas. A exceção foram as lesões autoprovocadas onde as intoxicações assumem esta posição.

Outras causas externas de traumatismos acidentais foi onde se verificou o maior percentual de ferimentos $(71,1 \%)$, já nos acidentes de transporte eles totalizaram $61,1 \%$ das lesões e foi aí que ocorreu a maior proporção de traumatismos superficiais 
(30,5\%). Apesar do número de ocorrências ter sido pequeno (cinco), assinale-se que dos agravos autoprovocadas $30,0 \%$ foram autointoxicações. Entretanto, devido ao pequeno tamanho da amostra estudada, não se pode estabelecer qualquer padrão. $O$ número de lesões por tipo de causa externa apresentou pequena variabilidade. Acidentes de transporte tiveram 1,8 lesões por evento; agressões 1,7; lesões autoprovocadas 1,3; outras causas externas de traumatismos acidentais 1,4. 
Tabela 16 - Lesões segundo tipo de causa externa de morbidade e mortalidade em pacientes atendidos em serviço de atenção às urgências no município de Pouso Alegre, MG, fevereiro a junho de 2003 (N. ${ }^{\circ}$ e \%)

\section{CAUSAS EXTERNAS}

$\begin{array}{ccccccc}\text { LESõES } & \begin{array}{c}\text { Acidente } \\ \text { transpor- } \\ \text { te }\end{array} & \begin{array}{c}\text { Agres- } \\ \text { sões }\end{array} & \begin{array}{c}\text { Auto- } \\ \text { provo- } \\ \text { cadas }\end{array} & \begin{array}{c}\text { Outras } \\ \text { causas } \\ \text { externas }\end{array} & \begin{array}{c}\text { Outros e } \\ \text { Indeter- } \\ \text { minados }\end{array} & \text { Total } \\ & & & & \end{array}$

\begin{tabular}{llllllllllll}
\hline $\mathrm{N}^{\circ}$ & $\%$ & $\mathrm{~N}^{\circ}$ & $\%$ & $\mathrm{~N}^{\circ}$ & $\%$ & $\mathrm{~N}^{\circ}$ & $\%$ & $\mathrm{~N}^{\circ}$ & $\%$ & $\mathrm{~N}^{\circ}$ & $\%$ \\
\hline
\end{tabular}

Traumatismo

superficial

$\begin{array}{llllllllllll}29 & 30,5 & 15 & 22,1 & 1 & 10,0 & 69 & 17,5 & - & - & 114 & 19,8\end{array}$

Ferimento $\begin{array}{llllllllllll}58 & 61,1 & 36 & 52,9 & 4 & 40,0 & 280 & 71,1 & 4 & 50,0 & 382 & 66,4\end{array}$ Luxação

Traumatismo de vasos sangüíneos

$$
\begin{array}{llllllllllll}
4 & 4,2 & 5 & 7,4 & - & - & 21 & 5,3 & - & - & 30 & 5,2
\end{array}
$$

Traumatismo de tendōes e músculos

Traumatismo de órgãos internos

$$
\begin{array}{lllllllllllll}
2 & 2,1 & 6 & 8,8 & - & - & 4 & 1,0 & - & - & 12 & 2,1
\end{array}
$$

Corpo estranho

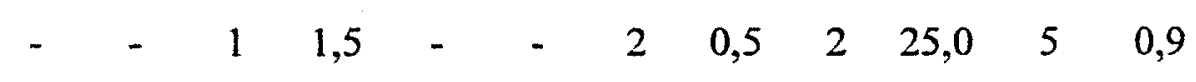

$\begin{array}{llllllllllllll}\text { Corpo estranho } & - & - & - & - & & 1 & 10,0 & 9 & 2,3 & - & - & 10 & 1,7\end{array}$

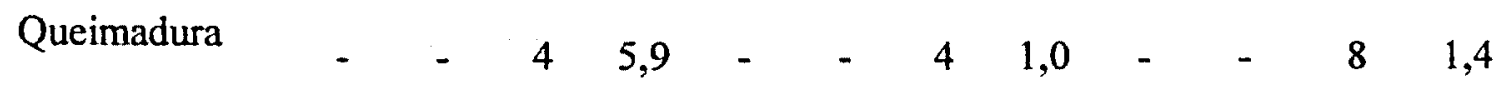

$\begin{array}{lllllllllllllll}\text { Fratura } & 2 & 2,1 & 1 & 1,5 & - & - & 4 & 1,0 & - & - & & 7 & 1,2\end{array}$

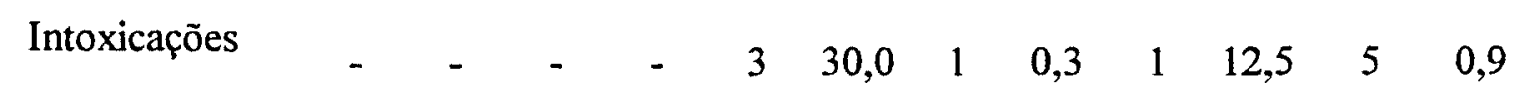

\begin{tabular}{ccccccccccccc} 
Desconhecida & - & - & - & - & - & - & - & - & 1 & 12,5 & 1 & 0,2 \\
\hline Total de Lesões & $\mathbf{9 5}$ & $\mathbf{1 0 0}$ & $\mathbf{6 8}$ & $\mathbf{1 0 0}$ & $\mathbf{1 0}$ & $\mathbf{1 0 0}$ & $\mathbf{3 9 4}$ & $\mathbf{1 0 0}$ & $\mathbf{8}$ & $\mathbf{1 0 0}$ & $\mathbf{5 7 5}$ & $\mathbf{1 0 0}$ \\
\hline
\end{tabular}

A figura 11 e a tabela 17 apresentam as lesões e suas respectivas topografias.

Os agravos mais comuns foram ferimentos nos membros superiores, cabeça e membros inferiores. Respectivamente: membros superiores (40,0\%), cabeça (27,9\%) e membros inferiores $(23,2 \%)$. Em seguida vêm, em ordem de ocorrências, os 
traumatismos superficiais de cabeça, membros inferiores e membros superiores. As luxações, entorses e distensões foram comuns nos membros inferiores e nos superiores com uma predominância do primeiro. Outras localizações, pelo número reduzido de ocorrências tiveram pequena participação no cômputo geral. Não se encontrou nenhuma ocorrência de trauma por esmagamento ou de nervos e medula espinhal. O segmento menos atingido do organismo foi o pélvico. Um dos traumatismos não teve informada nem sua natureza, nem sua localização. Analisando a relação entre tipos de lesões com a região anatômica, verifica-se que os tipos mais freqüentes foram os ferimentos de membros superiores, cabeça e membros inferiores e os traumatismos superficiais dentro destas mesmas localizações. Essas são as mais freqüentemente citadas em diversos estudos (ANDRADE, 1998; MESQUITA FILHO, 1998; MELLO JORGE $1980^{\mathrm{a}}$, 1980b, 1981), mas em ordens as mais diversas.

Figura 11 - Topografia de lesões cujas vítimas foram atendidas em serviço de atenção às urgências no município de Pouso Alegre, MG, fevereiro a junho de 2003

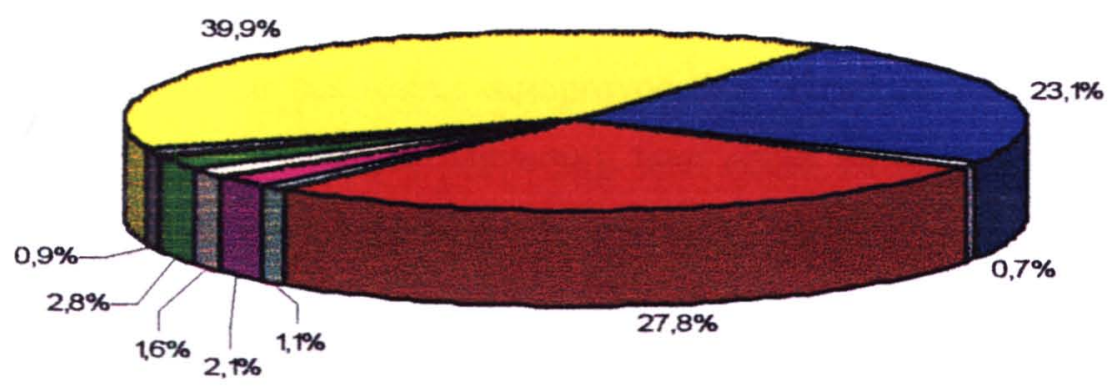

\begin{tabular}{lll}
\hline Cabeça & a Pescoço & $\square$ Tórax \\
$\square$ Abdome & $\square$ Dorso & $\square$ Pelve \\
$\square$ Membros superiores & $\square$ Membros inferiores & $\square$ indeterminado
\end{tabular}


Tabela 17 - Tipos e localização de lesões em pacientes atendidos em serviço de atenção às urgências no municipio de Pouso Alegre, MG, fevereiro a junho de 2003.

\begin{tabular}{|c|c|c|c|c|c|c|c|c|c|c|}
\hline \multirow[b]{2}{*}{ LESŌES } & \multicolumn{9}{|c|}{ LOCAIS } & \multirow[b]{2}{*}{ Total } \\
\hline & Cabeca & Pescoco & Tórax & Abdome & Dorso & Pelve & MMSS & MMII & Indet. & \\
\hline Traumatismo & & & & & & & & & & \\
\hline superficial & 37 & - & 4 & 2 & 7 & - & 28 & 36 & & 114 \\
\hline Ferimento & 106 & 3 & 5 & 3 & 7 & 5 & 179 & 74 & & 382 \\
\hline Luxação & 1 & - & 1 & 1 & 2 & - & 12 & 13 & & 30 \\
\hline $\begin{array}{l}\text { T vasos sangüineos } \\
\text { T tendðes e }\end{array}$ & 5 & 2 & - & - & 1 & - & 2 & 2 & & 12 \\
\hline músculos & - & 1 & - & - & - & - & - & - & & 1 \\
\hline $\mathrm{T}$ órgãos internos & 3 & - & - & 2 & - & - & - & - & & 5 \\
\hline Corpo estranho & 6 & - & - & - & - & - & 1 & 3 & & 10 \\
\hline Queimadura & - & - & 1 & 1 & 1 & - & 4 & 1 & & 8 \\
\hline Fratura & 1 & & 1 & & & & 2 & 3 & & 7 \\
\hline Outros & & & & & & & & & 1 & 1 \\
\hline Total & 159 & 6 & 12 & 9 & 16 & 5 & 228 & 132 & 4 & 570* \\
\hline
\end{tabular}

* O número de lesões não é de 575 nessa tabela pois ai não entraram as 5 intoxicações.

A figura 12 mostra quais os segmentos corporais que são proporcionalmente mais atingidos por lesões para cada tipo de causa externa, entre aquelas causadoras de maior número de casos. No cômputo geral, as localizações mais comuns foram membros superiores, cabeça e pescoço e membros inferiores. Nos acidentes de transporte os membros superiores foram as regiões mais atingidas $(33,7 \%)$, seguidas da cabeça e pescoço $(30,4 \%)$ e membros inferiores $(26,1 \%)$. A região do tronco, que englobou tórax, abdome, pelve e dorso, proporcionalmente, não sofreu tantas lesões $(9,8 \%)$. Já nas agressões e nas lesões autoprovocadas, a cabeça passa ter grande importância $(37,3 \%$ e $42,9 \%$ respectivamente), bem como os membros superiores $(34,3 \%$ e $42.9 \%)$. Estes dois segmentos se tratam de regiões muito expostas às situações de violência: a cabeça por ser alvo visado pelo agressor; já os membros superiores por serem freqüentemente utilizados em situações de autodefesa, estando portanto expostos aos impactos originários de atitudes beligerantes. $O$ grupo de causas que mais originou agravos (outras causas externas de traumatismos acidentais), por sua própria natureza acidental, teve uma importante concentração de agravos nos membros superiores $(43,7 \%)$, região do corpo mais utilizada nas tarefas diárias, no trabalho, nos afazeres domésticos, nas atividades de lazer e nas escolares. A cabeça e pescoço e os membros inferiores, tiveram proporções de ocorrência semelhantes entre si $(24,3 \%$ e $26,9 \%$ respectivamente). 
Figura 12 - Proporção de lesões apresentadas por segmento corpóreo atingido segundo algumas causas externas de morbidade e mortalidade em pacientes atendidos em serviço de atenção às urgências no município de Pouso Alegre, MG, fevereiro a junho de 2003.

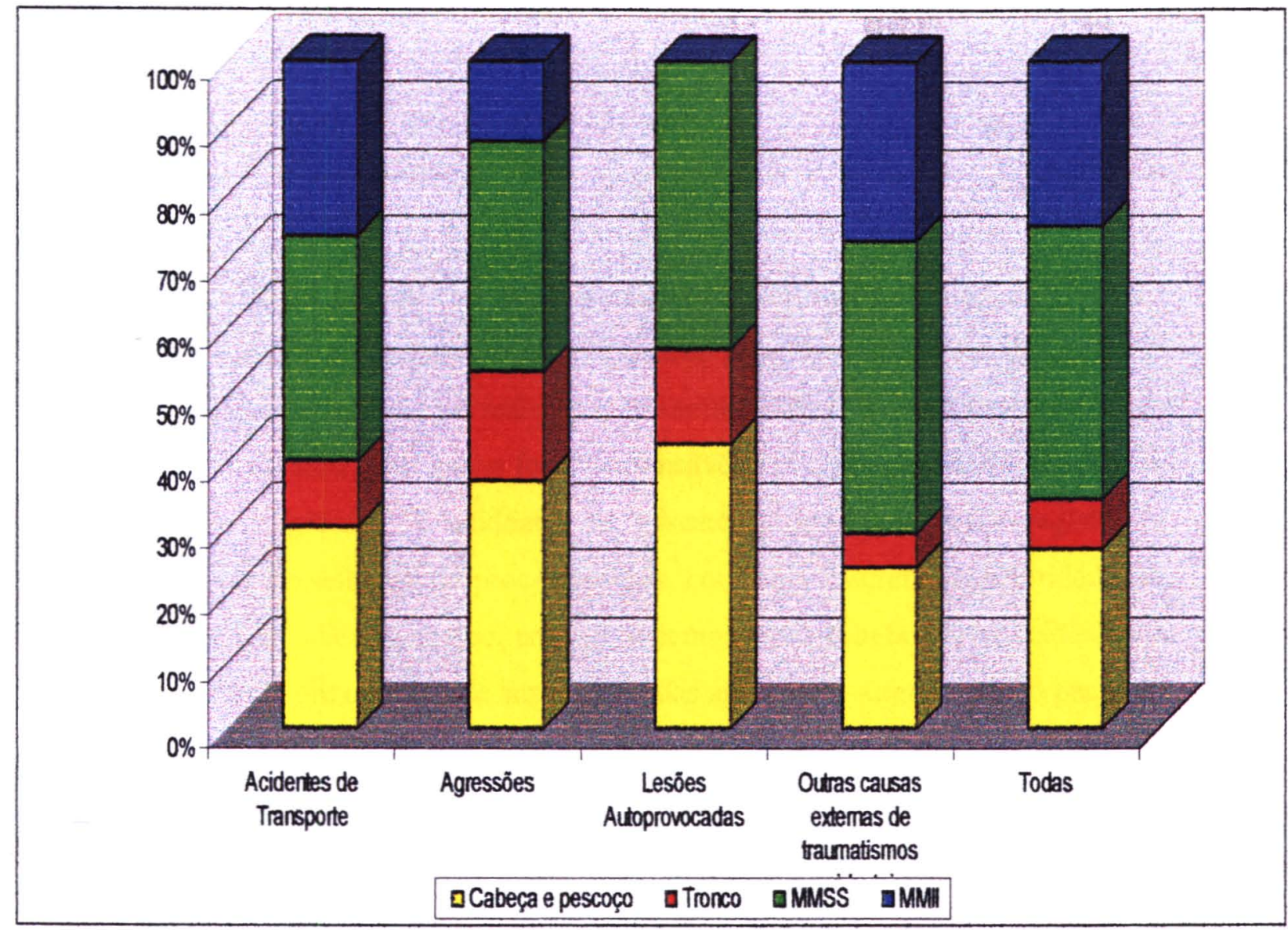

*Tronco: tórax, abdome, dorso e pelve.

\subsubsection{Procedimentos efetuados pelo serviço de saúde e destino dos pacientes}

Os 380 pacientes foram submetidos a um total de 873 procedimentos o que correspondeu a uma média de 2,3 procedimentos por paciente com um desvio padrão de 1,1 . $\mathrm{O}$ menor número de procedimentos recebido por um paciente foi zero e $\mathrm{o}$ maior foi cinco. A moda foram dois.

A tabela 18 mostra os procedimentos efetuados no serviço estudado. $\mathrm{O}$ procedimento mais efetuado foi a limpeza e curativo $(27,5 \%)$, seguido de sutura $(24,6 \%)$, orientação $(22,1 \%)$ e prescrição $(17,3 \%)$. No procedimento "outro" registraram-se principalmente vacinações anti-rábicas e antitetânicas. 
Tabela 18 - Procedimentos efetuados em vitimas causas externas de morbidade e mortalidade atendidas em serviço de atenção às urgências no município de Pouso Alegre, MG, fevereiro a junho de 2003

\begin{tabular}{lcc}
\hline PROCEDIMENTO & $\mathbf{N .}^{\mathbf{0}^{\circ}}$ & $\%$ \\
\hline Imobilização & 12 & 1,4 \\
Limpeza e curativo & 240 & 27,5 \\
Orientação & 193 & 22,1 \\
Prescrição & 151 & 17,3 \\
Sutura & 215 & 24,6 \\
Outro & 58 & 6,6 \\
Nenhum & 4 & 0,5 \\
\hline TOTAL & $\mathbf{8 7 3}$ & $\mathbf{1 0 0 , 0}$ \\
\hline
\end{tabular}

Na tabela 18 podem ser verificados os procedimentos efetuados no prontoatendimento por tipo de causas externas. O padrão geral foi seguido em outras lesões acidentais onde o procedimento mais comum também foi a limpeza e o curativo em $76,7 \%$ destas ocasiões. Essa causa foi a responsảvel por cerca de $70,0 \%$ de todos os procedimentos. Agressões e acidentes de trânsito, proporcionalmente registraram uma quantidade semelhante de procedimentos, com uma discreta superioridade dos segundos, mesmo sabendo-se que, conforme demonstra a tabela 19, os acidentes de trânsito ocorreram em quantidade superior ao das agressões. Apenas quatro pacientes não se submeteram a quaisquer procedimentos.

Tabela 19 - Procedimentos efetuados em vítimas causas externas de morbidade e mortalidade atendidas em serviço de atenção às urgências no municipio de Pouso Alegre, MG, fevereiro a junho de 2003, segundo causa externa.

\begin{tabular}{|c|c|c|c|c|c|c|}
\hline \multirow[b]{2}{*}{ PROCEDIMENTO } & \multicolumn{5}{|c|}{ CAUSAS EXTERNAS } & \multirow[b]{2}{*}{ Total } \\
\hline & $\begin{array}{l}\text { Acidentes } \\
\text { de } \\
\text { trânsito }\end{array}$ & Agressões & $\begin{array}{c}\text { Auto } \\
\text { provocadas }\end{array}$ & $\begin{array}{c}\text { Outras } \\
\text { lesões } \\
\text { acidentais }\end{array}$ & Outros & \\
\hline Imobilização & 3 & 1 & - & 8 & - & 12 \\
\hline Limpeza e curativo & 30 & 25 & 1 & 184 & - & 240 \\
\hline Nenhum & 1 & - & 1 & 2 & - & 4 \\
\hline Orientação & 27 & 16 & 2 & 148 & - & 193 \\
\hline Outro & 5 & 3 & 5 & 44 & 1 & 58 \\
\hline Prescrição & 17 & 26 & - & 108 & - & 151 \\
\hline Sutura & 25 & 25 & 3 & 162 & - & 215 \\
\hline Total & 108 & 96 & 12 & 656 & 1 & 873 \\
\hline
\end{tabular}


$\mathrm{O}$ destino tomado pelas vítimas e causas externas de morbidade e mortalidade atendidas foi em $92,6 \%$ dos casos de alta do serviço após a realização de procedimentos; $7,1 \%$ foram encaminhados para serviço de maior nível de complexidade e $0,3 \%$ (um paciente) passou mais de 24 horas em observação. Estes resultados são semelhantes aos encontrados por ANDRADE (1998) para o município de Londrina, tratando de vítimas de acidentes de transporte.

Os individuos que demandaram o serviço em sua maioria utilizaram veículo particular $(55,5 \%)$ para se deslocarem de sua origem até o serviço. Vieram a pé $23,7 \%, 9,5 \%$ de ônibus, $8,2 \%$ trazidos pela polícia e $3,1 \%$ utilizou-se de outros meios. $\mathrm{O}$ número expressivo de indivíduos que vieram a pé é de pessoas residentes no bairro São João, ou seja, nas cercanias do pronto-atendimento.

Quanto à gravidade das lesões encontradas não foi possível efetuar sua mensuração. São necessários estudos para se determinar em, nosso meio a escala mais adequada, com a simplicidade e a confiabilidade necessárias para uso no serviço de urgência/emergência. Num serviço de pronto-atendimento a escala de Glasgow não apresenta a utilidade prática que tem nas unidades de terapia intensiva ou em pacientes internados pois a maioria dos pacientes não apresenta problemas neurológicos ou coma.

O tempo médio de permanência foi de 77 minutos, com uma mediana e uma moda de 30 minutos. Permaneceram entre zero e 59 minutos $58,7 \%$ das vítimas de causas externas, acima de uma hora $27,1 \%$. Não se determinou o tempo de permanência de $14.2 \%$ dos pacientes (tabela 20).

Tabela 20 - Tempo de permanência no serviço de atendimento a urgências pelas vítimas de agravos ocasionados por causas externas de morbidade e mortalidade em Pouso Alegre, MG, 2002 (N. ${ }^{\circ}$ e \%).

\begin{tabular}{lrr}
\hline TEMPO DE PERMANENCIA & N. $^{\circ}$ & $\%$ \\
\hline 0 a 59 minutos & 223 & 58,7 \\
1:00 h e mais & 103 & 27,1 \\
Desconhecido & 54 & 14,2 \\
\hline Total & 380 & 100,0 \\
\hline
\end{tabular}




\section{5- CONCLUSÕES}

As conclusões aqui apresentadas dizem respeito a 380 pacientes, vitimas de causas externas de morbidade e mortalidade, residentes em Pouso Alegre, MG, atendidos no serviço de pronto-atendimento deste município, no período de fevereiro a junho de 2003.

1- Quanto à construção e teste da ficha de notificação de causas externas para serviços de urgência emergência:

- a ficha para coleta recebeu validação consensual (de face) e após estudo piloto chegou a formato definitivo;

- a aplicação e utilização da ficha foi viável em serviço de urgência/emergência, o trabalho de rotina não teve seu andamento prejudicado neste local que tem a característica de necessitar que as decisões e as ações sejam tomadas rapidamente. O tempo médio de aplicação foi de 6:54 minutos sendo a moda do tempo de aplicação 5:00 minutos;

- o instrumento não apresentou problemas de aceitação. Todos os pacientes e acompanhantes aceitaram conceder informações para seu preenchimento, não se registrando nenhuma recusa à participação na coleta de dados;

- a fidedignidade das respostas a respeito de destino do paciente e de agressões foi insatisfatória;

- foi de preenchimento fảcil e com número reduzidos de erros, após treinamento do pessoal em serviço;

- a reentrevista não pôde ser utilizada como padrão-ouro para realização de medidas de sensibilidade, especificidade e valores preditivos da ficha de notificação porque esteve sujeita a viéses, como a dificuldade em recordar variáveis como data e local pelo tempo transcorrido entre o atendimento e a reentrevista ;

- no relato dos indicadores das causas externas: agressões, e do destino do paciente: alta foi onde detectou-se maiores problemas relacionados à proporção bruta de concordâncias (PBC). Em agressões os viéses tiveram concentração mais alta quando a resposta era positiva ( $\mathrm{PBC}=43,0 \%$ ), já nas informações relativas à alta, quando era negativa $(\mathrm{PBC}=40,0 \%)$; 
- os indices Kappa sem ajuste, ou quando eram ajustados para viéses detectaram boa concordância entre dez dos doze indicadores estudados, excetuandose deste achado apenas dois: alta $(\mathrm{K}=0,37 \mathrm{E} \mathrm{BAK}=0,37)$ e agressões $(\mathrm{K}=0,34$ e $\operatorname{BAK}=0,33$;

- a concordância medida pelo Kappa ajustado simultaneamente para viéses e prevalência (PABAK) elevou o desempenho de dez dos doze indicadores estudados, notadamente aqueles que vinham apresentando índices que atestavam pior concordância (alta e agressões). $\mathrm{O}$ ajuste foi responsável por se obter resultados corrigidos destes indicadores que apresentaram melhores desempenho $e$ uniformidade com os demais. Os dois indicadores, cujo Kappa após ajuste não apresentou alteração substancial, eram os que já apresentavam mais altas concordâncias (localização: cabeça e, tipo de causa externa: acidente de transporte).

\section{2- Quanto ao fluxo das informações}

- A mainr parte dos pacientes chegou ao serviço de forma espontânea;

- a identificação da vítima era feita pelo pessoal administrativo da recepção do serviço;

- o pessoal de enfermagem preenchia a ficha de notificação durante ou após o atendimento;

- nos momentos de alto movimento a coleta de dados pode ser prejudicada por falta de disponibilidade de pessoal, que deve priorizar $o$ atendimento;

- o preenchimento das fichas de notificação apresentou inicialmente $20,0 \%$ de erros no estudo piloto. Essa proporção caiu em 15 dias para 2,0\% melhorando dia-a-dia;

- com o estabelecimento da rotina em submeter a ficha a dois procedimentos de crítica, um pela supervisão local e outro pelo pessoal do setor de epidemiologia da Secretaria Municipal de Saúde reduziu em muito a possibilidade de erros de preenchimento;

- o fluxo foi exclusivamente testado em nivel municipal;

- o trabalho continua em andamento. 


\section{3- Quanto às vitimas e circunstâncias dos agravos e lesões}

- As causas externas que mais ocorreram foram as classificadas dentro de "outras causas externas de traumatismos acidentais" com $73,2 \%$ das vitimas, a seguir vieram acidentes de transporte $(13,7 \%)$ e agressões $(10,8 \%)$;

- os individuos do sexo masculino foram os mais atingidos numa razão de 2,4 para 1,0;

- a grande maioria das vítimas era menor de 40 anos $(77,6 \%)$ sendo a faixa etária mais atingida a entre 20 e 39 anos. Entre as mulheres, ocorreu maior número de atendimentos nas que tinham entre 40 e 49 anos (4,0\%) e entre os homens nos de 30 a 39 anos (15,4\%). 24,8\% das vítimas tinham menos de 10 anos;

- houve predominância de vítimas que moravam nas imediações de onde se situa o serviço $(35,8 \%)$ e na região central da cidade $(25,8 \%)$;

- durante a semana ocorreram maior número de atendimentos nos sábados $(17,1 \%)$ e nos domingos $(16,6 \%)$. O dia de menor número de pacientes foi quinta feira;

- outras causas externas de lesões acidentais, acidentes de transponte e agressões tiveram uma maior ocorrência nos finais de semana;

- o horário de 12:00 às 17:59 h concentrou $52,1 \%$ dos casos, vindo em seguida o das 06:00 às $11: 59 \mathrm{~h}$ com 25,0\% das ocorrências;

- as causas externas tiveram como principal local de ocorrência a própria residência das vitimas $(40,3 \%)$. A seguir se apresentaram as ruas $(27,1 \%) \mathrm{e}$ locais de trabalho (12,6\%);

- num maior nível de detalhamento, quem mais causou vítimas foram as "outras causas externas de traumatismos acidentais" através de contato objeto cortante (21,6\% das ocorrências) seguida de quedas acidentais com $20,5 \%$ e ainda exposição a forças mecânicas animadas (ai representadas principalmente pelas mordeduras provocadas por cães) $14,5 \%$;

- $28,5 \%$ dos casos de outras causas externas de traumatismos acidentais tinha entre zero e nove anos de idade, abaixo dos trinta anos se acumularam 75,5\% das vitimas;

- a razão homem:mulher para estas causas foi de 2,1:1,0; 
- entre os acidentados de transporte $75,0 \%$ eram ciclistas, $9,6 \%$ motociclistas, $9,6 \%$ pedestres e $5,8 \%$ motorista ou passageiro de veículo a motor;

- $76,9 \%$ destes pacientes tinha entre 10 e 39 anos;

- $63,5 \%$ de quedas, $26,9 \%$ de colisões e $9,6 \%$ de atropelamentos foram as proporções de acidentes por tipo;

- das agressões $34,1 \%$ foram com o uso de força corporal; $31,7 \%$ objeto cortante; $31,7 \%$ objeto contundente;

- $56,1 \%$ das vítimas de agressão tinham menos de 30 anos de idade; $68,3 \%$ dos indivíduos que sofreram agressões eram do sexo masculino e $31,7 \%$ feminino;

- foram encontradas 575 lesões nos 380 indivíduos pesquisados, com uma média de 1,5 lesões por pessoa. Os acidentados de transporte foram os que apresentaram maior número de lesões por indivíduo: 1,8;

- $75,3 \%$ das vitimas apresentaram apenas uma lesão;

- as lesões mais encontradas foram os ferimentos com $66.4 \%$ e os traumatismos superficiais com 19,8\%, inclusive em todas as faixas etárias e em ambos os sexos;

- $72,6 \%$ dos pacientes portavam ferimentos, $22,6 \%$ traumatismos superficiais;

- as porções do organismo mais atingidas foram membros superiores $(40,0 \%)$, cabeça $(27,9 \%)$ e membros inferiores $(23,2 \%)$;

- nas agressões e lesões autoprovocadas a cabeça foi a região mais atingida ( 37,3 e $42,9 \%$ das lesões);

- o tipo mais comum de lesão também foi ferimento em cada um destes segmentos corpóreos, seguida novamente por traumatismos superficiais;

- os pacientes foram submetidos a 873 procedimentos sendo que o mais efetuado foi limpeza e curativo $(27,5 \%)$, seguido de sutura $(24,6 \%)$ e orientação $(22,1 \%)$;

- $92,6 \%$ dos pacientes tiveram alta após o atendimento;

- $58,7 \%$ permaneceu no serviço por menos de uma hora. 


\section{6- CONSIDERAÇÕES FINAIS}

Apesar das dificuldades encontradas, a viabilidade da construção de um sistema, que colete as informações sobre causas externas a partir dos serviços de urgência e emergência, é apontada por este trabalho. Uma das maiores dificuldades foi a de se estabelecer uma estratégia adequada para a da coleta de informações fidedignas em situações em que as pessoas muitas vezes omitem a verdade, como as de agressão e abuso. Os motivos para estas omissões são variados e vão desde o receio de complicações na área policial, até o medo de sofrer represálias de agressores ou por vergonha da exposição pública, entre outros. Outro desafio é o de viabilizar o preenchimento dos instrumentos de notificação no ambiente de urgência e emergência, onde o tempo é escasso e as necessidades das vitimas, muitas vezes, não podem esperar.

Os dados gerados são importantes e poderão municiar autoridades e gestores da área da saúde e de outras, que com ela tenham interfaces, para o desenvolvimento de politicns e programas de combate e prevenção a acidentes e violências. A necessidade de se implantar, neste pais, um sistema de informações que possa trazer estes subsidios é urgente. As notícias da implantação do Sistema de Informações em Saúde para Acidentes e Violências/ Causas Externas (SISAV) por parte do Ministério da Saúde são alvissareiras e para esse Sistema este estudo almeja trazer modesta contribuição. É fundamental que se levante quem são as pessoas mais vulneráveis às causas externas e as razões para tal, conhecendo desde as que vivem em situação de risco, passando pelas que portam lesões mais leves, até aquelas que vão ao óbito. São necessárias ações integrais, tanto do setor saúde como intersetoriais, envolvendo-se áreas afins para o equacionamento desta problemática. Estas ações devem ser estendidas a todos, em todos os lugares, inclusive tomando-se consciência de que problemas sérios ocorrem com freqüência, como se viu neste trabalho, mesmo em àmbito doméstico.

Nesta pesquisa foi chamada a atenção para certas causas externas que não costumam figurar nos estudos até agora efetuados no Brasil tais como as quedas acidentais, os ataques efetuados por cães, os acidentes com ciclistas. Esses achados, (que segundo o NCIPC em 2001, já são considerados prioridades de saúde pública para os EUA) demonstram a necessidade de se conhecer melhor a situação real do 
problema brasileiro. Por isso, é altamente recomendável que seja amplamente divulgado, discutido e implantado um Sistema Nacional de Vigilância a Causas Externas, sendo que a retomada do SISAV seria uma ótima medida.

É desejável que se prossigam os testes com a ficha de notificação de causas externas ampliando sua atuação também para serviço de emergência e verificando aí o funcionamento de seu fluxo e a morbidade encontrada. Entre os itens que podem ser acrescentados se encontram o registro, quando for o caso, de atendimento préhospitalar, uma melhor definição da ocupação da vítima e a determinação de maneiras de se avaliar a gravidade das lesões, através de instrumentos adequados.

Os achados do presente trabalho já possibilitaram algumas ações de saúde concretas no âmbito da cidade de Pouso Alegre, entre elas:

1: a continuidade do funcionamento da notificação completando no mês de novembro de 2003 dez meses ininterruptos. Tal fato está permitindo o fornecimento de dados para os serviços locais de saúde e um melhor planejamento das ações e das políticas municipais de saúde;

2- pelos problemas em relação às agressð̃es por cães intensificou-se a vacinação anti-rábica canina, realizando-se uma campanha extremamente divulgada, o que resultou na obtenção de alto patamar de cobertura vacinal;

3- foi elaborado projeto de construção de canil municipal.

Este é um campo do conhecimento da saúde que precisa ser ampliado e mais trabalhado. Trata-se de área em que são necessários novos estudos, para que a tragédia representada pelas mortes, incapacidades e sofrimento, muitissimas vezes em fases extremamente precoces da vida humana, tenha sua incidência reduzida para parâmetros menos sombrios. O tema é relevante e é óbvia a necessidade de aprofundamento do saber nesta área. É necessário que se conheça o que leva à ocorrência destes agravos, as circunstâncias que os envolvem, as formas de atenção aos problemas de saúde gerados, as características dos pacientes que procuram os serviços. Mais e mais deve ser incentivado o interesse em se produzir conhecimentos sobre estes importantes aspectos da Saúde Pública. 


\section{7 - REFERÊNCIAS BIBLIOGRÁFICAS}

ABRAMSON, JH - Making sense of data: a self-instruction manual on the interpretation of epidemiologic data. 2.ed. New York/Oxford Oxford University Press, 1994. 404p.

ABRAMSON, JH - Survey methods in community medicine. 4.ed. New York, Churchill Livingstone, 1990. 339p.

ALMEIDA FILHO, N \& ROUQUAYROL, MZ - Introdução à epidemiologia. 3ed. Rio de Janeiro, MEDSI, 2002. 293 p.

ANDRADE, SM - Acidentes de transporte terrestre em Londrina - Paraná: análise das vítimas, dos acidentes e das fontes de informação. São Paulo, 1998. [ Tese - Doutorado - Faculdade de Saúde Pública - Universidade de São Paulo].

ANNEST, JL; CONN, JM; JAMES, SP - Inventory of federal data systems in the United States, for injury surveillance, research and prevention activities. Atlanta CDC / NCIPC, 1996, 143p.

ASSOCIATION FOR ADVENCEMENT OF AUTOMOTIVE MEDICINE - The abbreviated injury scale - 1990 revision. Des Planes, AAAM, 1990. 74 p.

BAKER, SP; O' NEILL, B; GINSBURG, MG; LI, G - The injury fact book. 2.ed. New York, Oxford University Press, 1992. 344p.

BAKER,SP; LI,G; FOWLER, C; DANNENBERG, AL - Injuries to bicyclists: a national perspective. Baltimore, The Johns Hopkins Injury Prevention Center, 2002. $87 \mathrm{p}$.

BLINCOE, LJ - The economic cost of motor-vehicle crashes, 1994. Washington, DC: National Highway Traffic Safety Administration (NHTSA), NAD-40, 1996.

BRASIL - Lei 8080 de 18/09/90. In: CAMPOS, F.E.; OLIVEIRA JR.,M.; TONON, L. M. - Legislação básica do SUS. Belo Horizonte, COOPMED, 1998, p. 225-36.

BRASIL, MINISTĖRIO DA SAÙDE - Política Nacional de Redução da Morbimortalidade por Acidentes e Violências. Portaria MS/GM n. ${ }^{\circ} 737$ de 16/05/01. Brasilia, Ministério da Saúde, 2001.

BUSS, PM - Promoção da saúde e a saúde pública. Rio de Janeiro: ENSP/FIOCRUZ, 1998. 177 p. (mimeo).

CAVALCANTI, MLT - Prevenção da violência doméstica na perspectiva dos profissionais de saúde da familia. Ciência e Saúde Coletiva 4: 193-200, 1999. 
CENTERS FOR DISEASE CONTROL AND PREVENTION (CDC). -

Recommended framework for presenting injury mortality data. MMWR, 46 (No. RR-14): 1-17, 1997.

CÉSAR, CGL - O 'enfoque de risco' em saúde pública. In: BARRETO, ML; ALMEIDA F.', N; VERAS, RP; BARATA, RB - Epidemiologia, serviços e tecnologias em saúde. Rio de Janeiro, FIOCRUZ/ABRASCO, 1998. p. 79-92.

CHESNAIS, JC - Histoire de la violence. Paris: Robert Laford,1981. p. 275-94.

CONCHA-EASTMAN, A \& VILLAVECES, A- Guias para el diseño, implentación y evaluación de sistemas de vigilância epidemiológica de violencias y lesiones. Washington, DC, 2001. $46 \mathrm{p}$.

CONSUMER PRODUCT SAFETY COMISSION (CPSC)- National Electronic Injury Surveillance System: All Injury Program (NEISS-AIP) - available from http://www.cpsc.gov/about/clrnghse.html [2001, Set]

DEAN AG; DEAN, JA; COULOMBIER, D; BRENDEL, KA; SMITH, DC; BURTON, AH; DICKER,RC; SULLIVAN, K; FAGAN, RF; ARNER, TG; - EPIINFO Version 6: a word processing database and statistics program for epidemiology microcomputers. Atlanta, Centers for Disease Control, 1994. p. 7381.

DELATORRE, MCC - $O$ trânsito e seus novos centauros. In: VI Congresso Paulista de Saúde Pública - Anais, volume 1. Águas de Lindóia, APSP, 1999. p.283-90.

DESLANDES, SF - Atendimento às vítimas de violência na emergência: "prevenção numa hora desta?". Ciência e Saúde Coletiva 4: 81-94. 1999.

DESLANDES, SF; SILVA, MFP - Análise da mortalidade hospitalar por acidentes de trânsito em hospitais públicos do Rio de Janeiro, RJ, Brasil. Revista de Saúde Pública 34, p. 367-72, 2000.

DESLANDES,SF - Atenção à criança e adolescentes vítimas de violência doméstica: a análise de um serviço. Cadernos de Saúde Pública 10: 177-87. 1994.

DEVER, GEA - A epidemiologia na administração dos serviços de saúde. 1 ed. São Paulo, Pioneira, 1988.

FISHMAN, A; AGUIAR, CRS.; MINOTTO, R - Estudo descritivo sobre atropelamento no trânsito em Porto Alegre. Revista do HPS, Porto Alegre, 36: 12-5, 1990.

FLEISS, JL - Statistics methods for rates and proportions. 2.ed. New York, John Wiley \& Sons, 1981. 321p. 
FOUCAULT, M - Origens da Medicina Social. In: Microfísica do Poder, 12 ed., São Paulo, GRAAL, 1996. p.

FRIEDMAN, G: BORGES, LAA; CORONEL, A; VICENTINI, A; AGUIAR, CRS; VALANDRO, JL - Avaliação do trauma no H.P.S. através do escore de trauma. Revista do HPS, Porto Alegre, 37: 8-11, 1991.

GARCIA-MONTRONE, V.; ROSE, J.C. - Uma experiência educacional de incentivo ao aleitamento materno e estimulação do bebê, para mães de nivel sócio-econômico baixo: estudo preliminar. Cad. Saúde Públ., 12: 61-8, 1996.

GAWRYSZEWSKI, VP - a mortalidade por causas externas no município de São Paulo,1991. São Paulo, 1995. [Dissertação - Mestrado - Faculdade de Saúde Pública, Universidade de São Paulo].

GAWRYSZEWSKI, VP \& MELLO JORGE, MHP - Mortalidade violenta no município de São Paulo nos últimos quarenta anos. Revista Brasileira de Epidemiologia, 3: 50-69, 2000.

GRAITCER, PL Injury Surveillance. In: HALPERIN, W; BAKER JR, EL Public health surveillance. New York: Van Nostrand Reinhold, 1992, p. 142-56.

HOLDER, Y; PEDEN,M; KRUG, E ;.GURURAJ, G; KOBUSINGYE, O (eds.) Injury surveillance guidelines. 1 ed. Geneva, World Health Organization, 2001. 80 p.

INSTITUTO BRASILEIRO DE GEOGRAFIA E ESTATÍSTICA -IBGE. - Censo demográfico 2.000 - dados preliminares. Disponível em http://www.ibge.gov.br/ censo/default.php [outubro,2003]

IUNES, RF - Impacto econômico das causas externas no Brasil: um esforço de mensuração. In: MELLO JORGE, M H P, LAURENTI, R - Acidentes e violência no Brasil. Rev. Saúde Pública, 31 (supl.): p.38-46, 1997.

JENNET B, TEASDALE G, BRAAKMAN R, MINDERHOUD J, KNILLJONES R Predicting outcome in individual patients after severe head injury Lancet 1:1031$1034,1974$.

KLAUCKE, DN; BUELLER, JW; THACKER, SB; PARRISH, RG;

TROWBRIDGE, DL; BERKELMAN, RL - Guidelines for evaluating surveillance systems. MMWR 37 (S-5), 1-18, 1988.

KLEIN, CH - Mortes no trânsito do Rio de Janeiro, Brasil. Cad. Saúde Públ., 10 (supl. 1) : 168-76, 1994.

KLEIN,CH \& BLOCH, KV - Estudos seccionais. In: MEDRONHO, R.A. et al Epidemiologia 1 ed Rio de Janeiro - Atheneu, 2002. p.125-50. 
KRUG, E - Injury: a leading cause of the global burden of disease. 1 ed. Geneva: World Health Organization, 1999. p 3-7.

KURZ, R - Sinal verde para o caos da crise. In: KURZ, R- Os últimos combates. 3 ed. Petrópolis, Vozes, 1997. p. 347-75.

LALONDE, M - A new perspective in the health of canadians, Ottawa: Office the Canadian Minister of National Health and Welfares, 1974.

LAURELL, AC - A saúde-doença como processo social. In: NUNES, ED - Medicina Social: aspectos históricos e teóricos. 1 ed., São Paulo, Global, 1983. p. 135-58.

LAURENTI, R - Transição demográfica e transição epidemiológica. In: CONGRESSO BRASILEIRO DE EPIDEMIOLOGIA, 1, Campinas, 1990. Anais. Rio de Janeiro, ABRASCO, 1990. p. 143-165.

LAURENTI, R; GUERRA, MAT.; BASEOTTO, RA; KLINCERVICIUS, MT Alguns aspectos epidemiológicos da mortalidade por acidentes de trânsito de veículos a motor na cidade de São Paulo, Brasil. Rev. Saúde Pública, 6: 343-60, 1972.

LAURENTI,R; MELLO JORGE, MHP; LEBRÃO, ML; GOTLIEB, SLD Estatísticas de Saúde - 2 ed. São Paulo: EPU, 1987. p. 1-2.

LAURENTI, R \& MELLO JORGE, MHP - O atestadu dit ubito - São Paulo: OMS/ NEPS/USP, $1996.87 \mathrm{p}$.

LEAVELL, H; CLARK, HG - Niveis de aplicação da medicina preventiva. In:

Medicina Preventiva. 1. ed. Rio de Janeiro, McGraw- Hill do Brasil, 1978. p. 11 36.

LEBRÃO, ML ; MELLO JORGE, MHP; LAURENTI, R-II - Morbidade hospitalar por lesões e envenenamentos. In: MELLO JORGE, MHP, LAURENTI, R - Acidentes e violência no Brasil. Rev. Saúde Pública, 31 (supl.): p.26-37, 1997.

LÓPEZ, MVL; MEDINA, MCH; PACHECO, RAR; MUÑOZ, JB - Muertes por homicidio, consecuencia fatal de la violencia. El caso de Mexico, 1979-1992. Rev. Saúde Pública, 30: 46-52, 1996.

MACHADO, JMN; GOMEZ, CM - Acidentes de trabalho: uma expressão da violência social. Cadernos de Saúde Pública 10 (supl 1): 74-86. 1994

MASSIE,DL et al - Traffic accident involvement rates by driver age and sex. Accid. Anal. Prev. 27: 73-87, 1995.

MÉDICI, AC - As raizes econômicas da violência e seus impactos na saúde. Saúde em Debate, 34: 40-6, 1992. 
MELLO JORGE, MHP - À guisa de conclusão. In: MELLO JORGE, MHP, LAURENTI, R - Acidentes e violência no Brasil. Rev. Saúde Pública, 31 (supl.) : p. $51-4,1997$ b.

MELLO JORGE, MHP , GAWRYSZEWSKI, V P, LATORRE, M R D - I -Análise dos dados de mortalidade. In: MELLO JORGE, $M$ H P, LAURENTI, $R$ - Acidentes e violência no Brasil. Rev. Saúde Pública, 31 (supl.) : p. 5-25, 1997a.

MELLO JORGE, MHP - Investigação sobre a mortalidade por acidentes e violências na infância. São Paulo, 1988. [Tese - Livre Docência - Faculdade de Saúde Pública, Universidade de São Paulo].

MELLO JORGE, MHP de - Situação atual das estatísticas oficiais relativas à mortalidade por causas externas. Rev. Saúde Pública, 24: 217-23, 1990.

MELLO JORGE, MHP - Mortalidade por causas violentas no municipio de São Paulo. I - Mortalidade violenta no tempo. Rev. Saúde Pública, 14: 343-57, 1980a.

MELLO JORGE, MHP - Mortalidade por causas violentas no município de São Paulo. II - Mortes acidentais. Rev. Saúde Pública, 14: 475-508, $1980 \mathrm{~b}$.

MELLO JORGE, MHP - Mortalidade por causas violentas no município de São Paulo. III - Mortes intencionais. Rev. Saúde Pública, 15: 165-93, 1981.

MELLO JORGE, MHP - Mortalidade por causas violentas no município de São Paulo. IV - Situação em 1980. Rev. Saúde Pública, 16: 19-41, 1982.

MELLO JORGE, MHP ; MARQUES, MB. - Mortes violentas em menores de 15 anos no Brasil. Bol. Of. Sanit. Panam., 100: 590-605, 1986.

MELLO JORGE, MHP; LATORRE, MRDO - Acidentes de trânsito no Brasil: Dados e tendências. Cad. Saúde Públ., 10 (supl. 1) : 19-44, 1994

MELLO JORGE, MHP, GOTLIEB,SLD, SOBOLL, MLMS, BALDIJÃO, MFA, LATORRE, MRDO - $O$ sistema de informação sobre nascidos vivos - SINASC. São Paulo: OMS/ NEPS/USP, 1992. 47 p.

MELLO JORGE, MHP; GOTLIEB, SLD - As condições de saúde do Brasil: retrospecto de 1979 a 1995. Rio de Janeiro: FIOCRUZ, 2000. $280 \mathrm{p}$.

MELLO JORGE, MHP; GOTLIEB, SLD; LAURENTI, R - O sistema de informações de mortalidade: problemas e propostas para seu enfrentamento. IIMortes por causas externas. Revista Brasileira de Epidemiologia 5: 212-23, 2002.

MESQUITA FILHO, $\mathrm{M}$ - A morbidade por acidentes de trânsito em Pouso Alegre, Minas Gerais. São Paulo, 1998. [ Tese-Mestrado - Universidade Federal de São Paulo], 172 p. 
MESQUITA FILHO, M; DAOLIO,A; MIRANDOLA,GM; TEIXEIRA,VA - Estudo de concordância entre prontuários de serviço de urgência e entrevistas com acidentados no trânsito em 1994. In; IV Congresso Brasileiro de Epidemiologia Livro de Resumos. Rio de Janeiro, ABRASCO, 1998, p. 155.

MINAYO, MCS ; SOUZA, ER - Violência para todos. Cad. Saúde Pública, 9: 6578, 1993.

MINAYO, MCS - A violência social sob a perspectiva da saúde pública. Cad. Saúde Públ., 10 (supl. 1) : 07-18, 1994.

MINAYO, MCS \& SOUZA, ER - É possivel prevenir a violência? Reflexões a partir do campo da saúde pública. Ciência e Saúde Coletiva 4: 7-23. 1999.

MINAYO, MCS. - A violência na adolescência: um problema de saúde pública. Cad. Saúde Pública, 6: 278-92, 1990

MINISTÉRIO DA SAÚDE; FUNDAÇÃO NACIONAL DE SAÚDE; CENTRO NACIONAL DE EPIDEMIOLOGIA. Guia de vigilância epidemiológica. Brasilia: Fundação Nacional de Saúde, 1998, 4ed., cap.l e 3.

MINISTÉRIO DA SAÚDE; FUNDAÇÃO NACIONAL DE SAÚDE; CENTRO NACIONAL DE EPIDFMIOLOGIA. Guia de vigilância epidemiológica. Brasilia: Fundação Nacional de Saúde, 2002. 5ed., v.I, p.61-77.

MORAES, IHS - Política, tecnologia e informação em saúde: a utopia da emancipação. 1 ed. Salvador: Casa da Qualidade Editora, 2002. 171 p.

MORDIBITY AND MORTALITY WEEKLY REPORT (MMWR) - National estimates of nonfatal injuries treated in hospital emergency departments - United States, 2000. MMWR 50: 340-6. 2001.

MOTA,E \& CARVALHO, DM - Sistemas de informação em saúde.

In:ROUQUAYROL, M Z \& ALMEIDA FILHO, N - Epidemiologia e Saúde. 6 ed. Rio de Janeiro: MEDSI, 1999; p. 505-21.

NATIONAL CENTER FOR INJURY PREVENTION AND CONTROL ( NCIPC) Risk driving behaviors among teenagers - Gwinnet County, Georgia, 1993. In: Prevention of motor vehicle - related injuries: a compendium of articles fron the morbidity and mortality Weekly Report, 1985-1996. 1.ed. Atlanta, Centers for Disease Control and Prevention, 1997. p. 51-5.

NATIONAL CENTER FOR INJURY PREVENTION AND CONTROL (NCIPC) Home and leisure injuries in the United States: a compendium of articles from the Morbidity and Mortality Weekly Report. led. Atlanta: Centers for Disease Control and Prevention (CDC); 1996. 199p. 
NATIONAL CENTER FOR INJURY PREVENTION AND CONTROL (NCIPC) Injury fact book 2001-2002. led. Atlanta: Centers for Disease Control and Prevention (CDC); 2001. 129p.

NATIONAL COMMITTEE FOR INJURY PREVENTION AND CONTROL (NCIPC) - Injury prevention meeting the challenge. 1.ed. New York, Oxford University Press, American Journal of Preventive Medicine, v5, n3 (suppl.), 1989. $303 \mathrm{p}$.

NUNES, ED- Debatedor: É possível prevenir a violência? Reflexões a partir do campo da saúde pública. Ciência e Saúde Coletiva 4: 24-5. 1999.

OMRAN, AR - The epidemiologic transition. A theory of the epidemiology of population change. The Milbank Memorial Foundation Quarterly, 49 (part 1): 509-38, 1971 .

ORDONES, O; VANOLLI, H (eds.) - Plan de acción regional sobre violencia y salud. Memórias de la conferencia interamericana sobre sociedad, violencia y salud. Washington: OPS/OMS: 1995.

ORGANIZAÇÃO MUNDIAL DA SAÚDE (OMS) - Classificação estatística internacional de doenças e problemas relacionados à saúde, décima revisão. 2.ed. São Paulo, EDUSP, 1995. 1191p.

ORGANIZACION MUNDIAL DE LA SALUD (OMS); ORGANIZACIÓN PANAMERICANA DE LA SALUD (OPAS) - Volencia y salud. Tema 4.12 del programa provisional. In: Reunión del comité ejecutivo del consejo directivo (opas) y el grupo de trabajo del comité regional(oms) 111. ${ }^{\text {a }}$, Washington, D.C., CE111/19 (Esp.). Washington, D.C., OPAS, 1993 a. P. 1-17.

ORGANIZACION MUNDIAL DE LA SALUD (OMS);ORGANIZACION PANAMERICANA DE LA SALUD (OPAS) - Resolucion XIX de $10^{\circ}$ de octubre de 1993: Violencia y Salud, Washington, D.C., p 1-3, 1993 b.

OTT, ALF.; FAVARETTO, ALF.; NETO, AFPR.; ZECHIN, JG.; BORDIN, R Acidentes de trânsito em área metropolitana da Região Sul do Brasil - Caracterização das vitimas e das lesões. Rev. Saúde Pública, 27: 350-6, 1993

PEREIRA, MG- Reprodutibilidade de um teste diagnóstico. In: Epidemiologia teoria e prática. 1.ed. Rio de Janeiro, Guanabara Koogan, 1995. p.364-7.

RIPSA - REDE INTERAGENCIAL DE INFORMAÇÕES PARA A SAÚDE Indicadores básicos para a saúde no Brasil: conceitos e aplicações. 1 ed. Brasilia, Organização Panamericana de Saúde (OPAS), 2002. 299 p.

ROBERTSON, LS - Injury epidemiology. 1.ed. New York, Oxford University Press, 1992. 241p. 
SALTZMAN, LE \& IKEDA, RM - Recommended data elements for firearm-related injury surveillance. American Journal of Preventive Medicine15:113-8. 1998.

SANCHES, KRB; CAMARGO JR, KR; COELI, CM; CASCÃO, AM - Sistemas de informação em saúde. In: MEDRONHO, R.A. et al - Epidemiologia 1 ed. Rio de Janeiro - Atheneu, 2002. p.337-57.

SANTANA, VS.; ALMEIDA FILHO, N; ROCHA, CO; MATOS. AS -

Confiabilidade e viés do informante secundário na pesquisa epidemiológica: análise de questionário para triagem de transtornos mentais. Rev. Saúde Pública, 31: 556-65. 1997

SCARINGELLA, RS- Debatedor: É possível prevenir a violência? Reflexões a partir do campo da saúde pública. Ciência e Saúde Coletiva 4: 28-9. 1999.

SCHLESSELMAN, JJ - Case-control studies - Design, conduct, analysis. 1.ed. New York, Oxford University Press, 1987. p. 90-104.

SCHRAIBER,LB; D'OLIVEIRA, AFLP - Violência contra mulheres: interfaces com a saúde. Interface - Comunicação,Saúde e Educação 5:11-26. 1999.

SIMÕES, CCS. - A morte por violências do jovem brasileiro. In: Perfis de saúde e de mortalidade no Brasil: uma análise de seus condicionantes em grupos populacionais єspecíficos. Brasilia: Organizaçâo Pan-Americana de Saúde, 2002. p. 87-108.

STEDMAN,TL - Stedman dicionário medico. 25 ed. Rio de Janeiro, Guanabara Koogan, 1996, 1657 p.

TEASDALE G, JENNETT B - Assessment and prognosis of coma after head injury. Acta Neurochir 34:45-55. 1976.

TEASDALE G, JENNETT B - Assessment of coma and impaired consciousness. Lancet 81-84. 1974.

THORNTON, TN; CRAFT, CA; DAHLBERG, LL; LYNCH, BS; BAER, K Prácticas óptimas para la prevención de la violencia juvenil: libro de referencia para la acción comunitaria. Atlanta: CDC, NCIPC, 2000. 226p.

VERMELHO, LL \& MONTEIRO, MFG - Transição demográfica e epidemiológica. In: MEDRONHO, R.A. et al - Epidemiologia 1 ed. Rio de Janeiro - Atheneu, 2002. p. 91-103.

WALDMAN, EA; MELLO JORGE, MHP - Vigilância para acidentes e violência: instrumento para estratégias de prevenção e controle. Ciência e Saúde Coletiva 4: 71-9. 1999.

WATERS, C et al. - Motor vehicle traffic accidents in Canada, 1978-87 by time of occurrence. Rev Can. Santè Publique.84: 58-9, 1993. 
YUNES, $\mathrm{J}$ - Mortality from violent causes in the Americas. Bulletin of PAHO, 27: 154-67, 1993 
ANEXO 1 
FICHA DE NOTIFICAÇÃO DE CAUSAS EXTERNAS EM PRONTO SOCORRO A1-HORA DE INICIO DA COLETA DE DADOS:

\section{I - IDENTIFICAÇÃO \\ Nome: $n^{0}$ do cartão SUS}

Endereço

Bairro

CEP Cidade

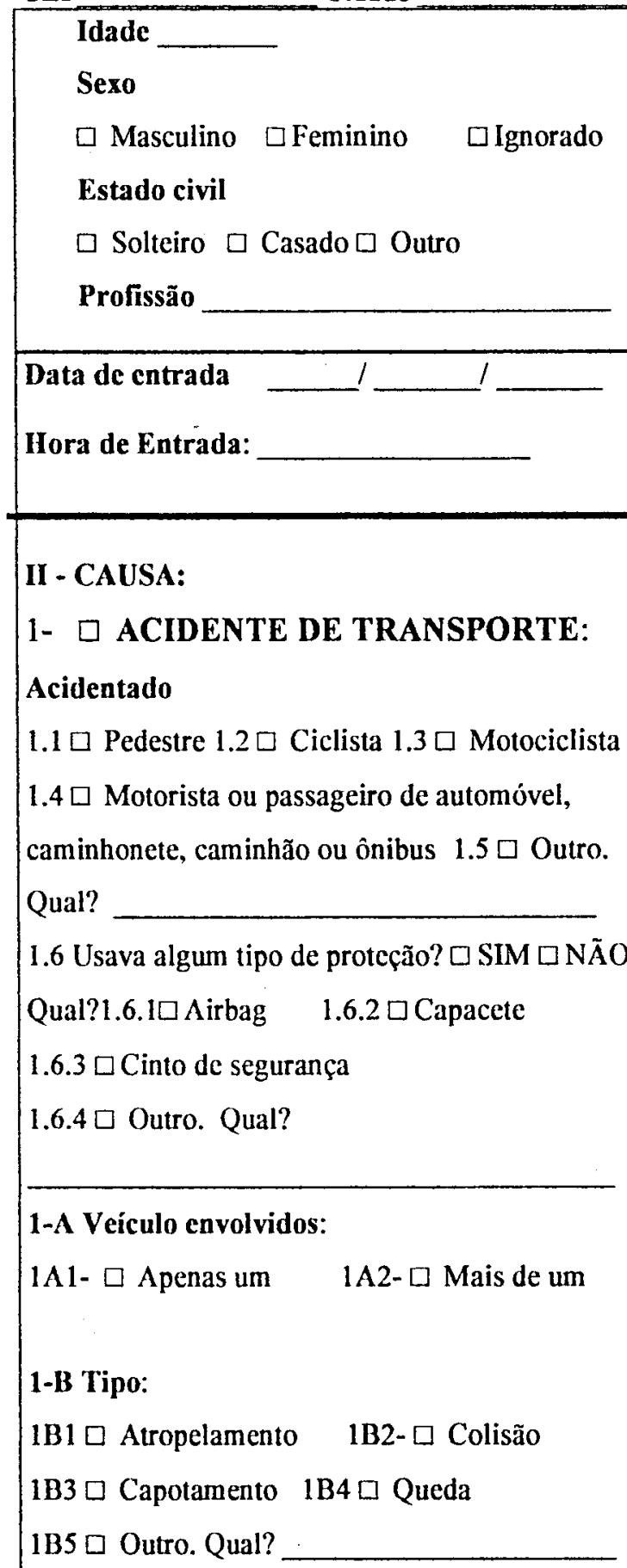




\begin{tabular}{l} 
5- $\square$ OUTROS EVENTOS DE INTENÇ̃̃O \\
INDETERMINADA. QUAL? \\
6- $\square$ INTERVENÇÕES LEGAIS E \\
OPERAÇÕES DE GUERRA. \\
QUAL? \\
7- O OUTROS Quais? \\
\hline
\end{tabular}

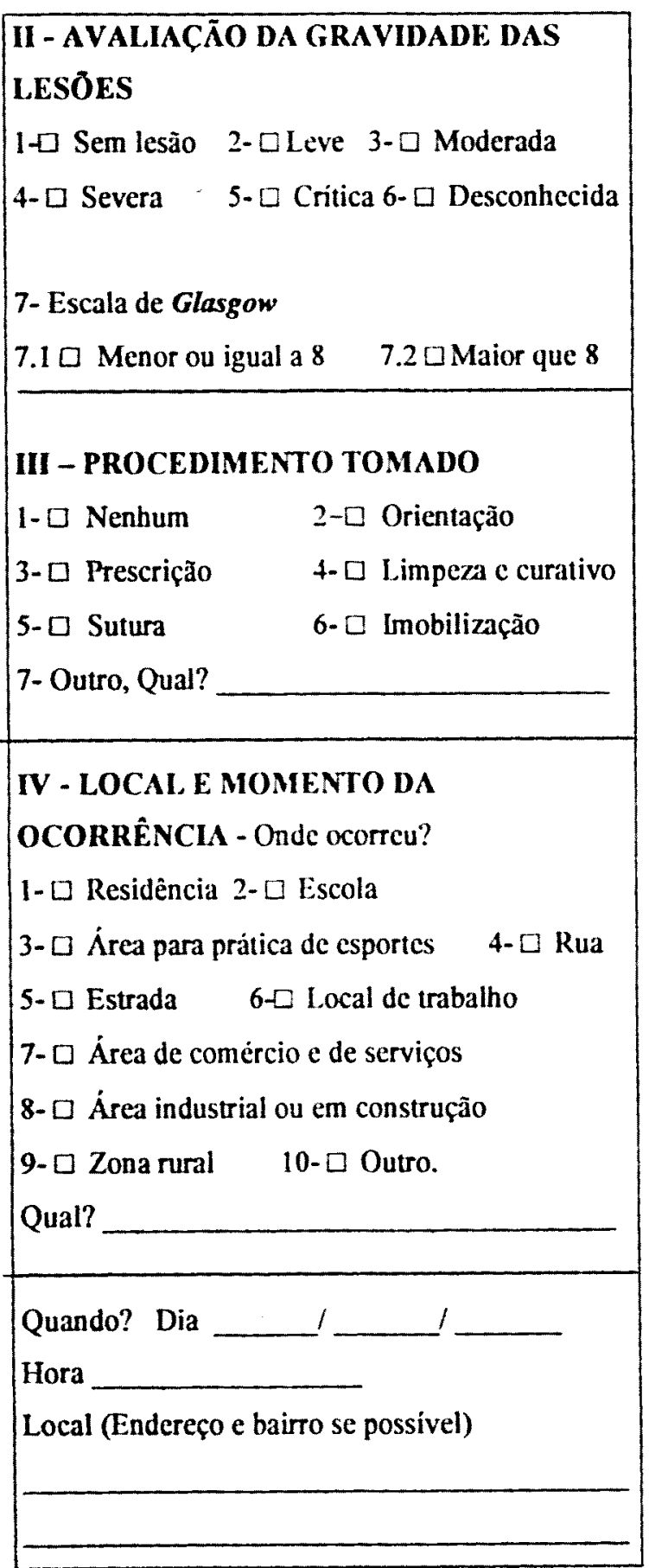

\section{V- COMO O PACIENTE CIIEGOU AO} PRONTO-SOCORRO?

$1-\square$ A pé 2- $\square$ Trazido pela Polícia

3- $\square$ Por ambulância 4- $\square$ Transporte particular

5- $\square$ Ônibus 6- $\square$ Táxi

7. $\square$ Outro. Qual?

\begin{tabular}{|c|c|}
\hline \multicolumn{2}{|c|}{ VI - DESTINO DO PACIENTE } \\
\hline $1-\square$ Alta & 2- $\square$ Internação \\
\hline 3- $\square$ Encaminhamento & 4- $\square$ Óbito \\
\hline 5- $\square$ Ignorado & \\
\hline
\end{tabular}

VII TEMPO DE PERMANÊNCIA

Nome do pesquisador

Data do preenchimento 
VII - LESÃO E LOCALIZAÇÃO (PREENCHER LSANDO O VUMMERO DE LESÕES POR LOC.ALIZ.AÇÃO)

\begin{tabular}{|c|c|c|c|c|c|c|c|c|}
\hline & 1- Cabeça & 2-Pescoço & 3-Tórax & 4- Abdome & 5-Dorso & 6-Pelve & $\begin{array}{l}\text { 8- Membro } \\
\text { superior }\end{array}$ & $\begin{array}{l}\text { 9- Membro } \\
\text { inferior }\end{array}$ \\
\hline \multicolumn{9}{|c|}{ 1- Traumatismo superficial } \\
\hline \multicolumn{9}{|l|}{ 2- Ferimento } \\
\hline \multicolumn{9}{|c|}{ 3-Luxação, entorse, distensåo } \\
\hline \multicolumn{9}{|c|}{ 4- Traumatismos nervos e medula espinhal } \\
\hline \multicolumn{9}{|c|}{ 5- Traumatismo vasos sanguíneos } \\
\hline \multicolumn{9}{|c|}{ 6- Traumatismo tendões e músculos } \\
\hline \multicolumn{9}{|c|}{ 7- Traumatismos órgãos internos } \\
\hline \multicolumn{9}{|c|}{ 8- Lesões por esmagamento } \\
\hline \multicolumn{9}{|l|}{ 9- Corpo estranho } \\
\hline 10- Queimaduras & & & & & & & & \\
\hline
\end{tabular}

\section{1- $\square$ FRATURA}
11.1 $\sqsubset$ Crânio e ossos da face $11.2 \sqsubset$ Pescoço $11.3 \sqsubset$ Tórax 11.4 $\sqsubset$ Cuiuna torácica $11.5 \sqsubset$ Coluna dorsal

12- $\square$ INTOXICAÇĀO. Causada por

13- $\square$ Outras. Quais?

\section{DESCRIÇÃO DAS LESÕES}


ANEXO 2 
Faculdade de Saúde Pública

Universidade de São Paulo

\section{Estudo Piloto Sobre Instrumento de Notificação de Causas Externas: Contribuição a Um Sistema de Informações de Acidentes e Violências}

Estudo desenvolvido dentro do projeto da Tese de Doutorado "Estude ie Vitimas de Causas Externas Atendidas em Serviços de Urgência e Emergência para o Desenvolvimento de Sistema de Informações".

Autor: Marcos Mesquita Filho

Orientadora: Professora Doutora Maria Helena do Prado Mello Jorge 


\section{1- Introdução}

Entre os graves problemas de saúde pública que acontecem em nosso meio, aqueles que são ocasionados pelas chamadas causas externas de lesão ocupam lugar de destaque. Tratam-se de agravos à saúde que muitas vezes atingem extrema gravidade, sendo importantes causas de morte e incapacidade.

O Brasil, apesar de ter mostrado nos últimos vinte anos o crescimento da esperança de vida ao nascer, a queda das taxas de mortalidade infantil e da taxa geral de fecundidade, vem apresentando um perfil epidemiológico crítico, caracterizado pela presença concomitante de doenças de paises desenvolvidos e das dos em desenvolvimento, agravado pelo recrudescimento de doenças consideradas erradicadas ou sob controle. A este cenário desfavorável soma-se a importância das causas externas, principalmente acidentes de trânsito e homicidios enquanto geradoras de óbitos, lesões e incapacidades em variados graus. Para se ter uma idéia, entre 1991 e 1998, a taxa de mortalidade por homicídios no Brasil cresceu de 20,9 para 25,9 óbitos por cem mil habitantes. Na região Sudeste a situação é mais grave pois estas taxas aumentaram de 27,0 para 35,9 . Se forem consideradas todas as causas externas os números do país passam respectivamente a ser de 69,5 e 72,7 óbitos por cem mil habitantes. As causas externas foram também responsáveis por 5,8 por cento das internações hospitalares no país em 1998, chegando na região Sudeste a 6,8 por cento (RIPSA, 2002).

Hoje no Brasil, essas causas só apresentam taxas de mortalidade inferiores às das doenças do aparelho circulatório. Atingem preferencialmente estratos mais jovens da populą̧ão e pacientes do sexo masculino, apesar de apresentarem importância nas faixas etárias mais avançadas. Em relação às causas externas, as Declarações de Óbitos, apesar de constituirem boa fonte de informações do ponto de vista quantitativo, com dados que demonstram a gravidade do problema, qualitativamente deixam muito a desejar. A situação se revela mais séria quando se constata que dados a respeito de mortalidade ainda são subnotificados em muitos locais do Brasil.

Informações referentes a vítimas não-fatais de violências e acidentes ainda são de pior qualidade. Não existe um sistema estruturado que permita sua captação. "No Brasil, somente são conhecidos os dados de hospitalizações pagas pelo Sistema Único de Saúde (SUS), que têm inicio com o documento Autorização de Internação Hospitalar (AIH), preenchido nos hospitais, obrigatório para recebimento de pagamento referentes a essas internações" (WALDMAN \& MELLO JORGE, 1999). Estas informações, por serem geradas com finalidades administrativas, contribuem pouco para o conhecimento das caracteristicas reais 
das circunstâncias, das lesões, dos fatores de risco e/ou de proteção associados. Além disso, não existe o preenchimento das AIH ou de qualquer outra fonte de informação em ambiente de pronto-socorro, onde se concentra a maior parte dos atendimentos às vítimas de causas externas.

ANDRADE (1998), trabalhando com inúmeras fontes de dados, observou que apenas $22,5 \%$ das vítimas de acidentes de transporte terrestre, atendidas em pronto-socorro, foram captadas pelos registros policiais, em comparação a $48,8 \%$ das internadas e $86,2 \%$ das falecidas. O Sistema de Informações sobre acidentes de trabalho (SISCAT) não captou 46,8\% de acidentados que eram concomitantemente vítimas de acidentes de trabalho e dos de trânsito. A má qualidade da informação é evidente quando se verifica que as fichas de prontosocorro, internação e declarações de óbito apresentaram um percentual de causas externas de tipo ignorado de $9,2 \%, 38,4 \%$ e $35,4 \%$. Quanto a acidentes de trânsito de tipo não especificado encontrou-se, respectivamente, 18,0\%, 10,9\% e 44,6\%. Além disso, usou-se indevidamente o termo "atropelamento" para ciclistas e motociclistas que colidiram com outros veiculos.

As conseqüências originadas por causas externas de lesões e óbitos, principalmente no campo das violências, apesar de apresentarem caracictiỏiticas multifacetadas da sua gênese e ocorrência, têm entre suas conseqüências uma repercussão direta sobre o setor saúde. Seus resultados aí se manifestam principalmente pela demanda de suas vítimas aos serviços destinados às urgências e às emergências. De acordo com a OMS/OPAS (1993a) "o setor saúde constitui a encruzilhada para onde confluem todos os corolários da violência, pela pressão que exercem suas vitimas sobre os serviços de urgência, de atenção especializada, de reabilitação fisica, psicológica e de assistência social". O relatório da $111^{a}$ reunião conjunta da OPAS e da OMS, realizada em Washington em junho/julho de 1993, afirma que "a violência, pelo número de vítimas e magnitude de seqüelas orgânicas e emocionais que produz, adquiriu um caráter endêmico e se converteu num problema de saúde pública em vários países" e ainda que "a violência afeta todos os estratos da sociedade". A resolução XIX, apresentada na XXXVII reunião do conselho diretivo da OMS/OPAS, "Violencia y Salud" (OMS/OPAS, 1993b) salienta que "a prevenção da violência é possivel por ser expressão de comportamentos humanos, atitudes e estilos de vida modificáveis mediante ações de promoção da saúde". É verdade que parte das medidas preventivas não são atribuição exclusiva da área da saúde, mas também de outros setores sociais. A citada resolução XIX contudo afirma que "o setor saúde deveria desempenhar um papel fundamental junto com outros setores na busca de soluções e aplicação de medidas preventivas e de controle de todas 
as formas de violência" (OMS/OPAS, 1993b). Entretanto, como expõe o relatório final da $111^{a}$ reunião da OMS/OPAS (1993a), "a resposta do setor saúde tem sido insuficiente. Concentrou-se na atenção imediata às lesões. Mesmo nesse campo a cobertura é incompleta e a acessibilidade aos serviços é limitada; apenas em pequeno grau enfoca aspectos psicossociais e de reabilitação. As ações de prevenção têm sido escassas e, em geral, limitadas a experiências isoladas". Apesar dessa baixa capacidade em dar respostas adequadas, os custos para os sistemas de saúde são altissimos e seriam provavelmente ainda maiores se as ações exercidas fossem de boa qualidade. Entretanto, é importante que "mesmo que os sistemas de saúde não estejam adequadamente preparados para atender o quadro de morbimortalidade trazido pela violência em seus distintos matizes, não se deve 'banalizar o fenômeno' ou enquadrar a violência dentro de parâmetros de normalidade". No Brasil, os serviços de saúde estão, geralmente, pouco alertas e motivados para a problemática. Existem propostas de politicas públicas para sua prevenção e atenção que ainda não entraram em vigor, bem como, ainda não se desenvolveu instrumental adequado para equacioná-la. Entretanto, por ser "um problema das condições políticas, sociais e econômicas, a 'epidemiologia da violência' encontra fora dos serviços de saúde seu principal 'locus' de causalidade e resolutividade (...); medidas de âmbito politico, normativo-institucionel, social e econômico poderão" prevenir e "resolver boa parte dos problemas de saúde causados pela violência" (MÉDICI, 1992).

Para que violências possam ser equacionadas em seus aspectos ligados à saúde pública necessita-se do estabelecimento de algumas diretrizes minimas. Nesta área, a epidemiologia é ferramenta indispensável para sua abordagem. Como informa DEVER (1988), principios e métodos epidemiológicos podem ser aplicados a uma grande variedade de problemas. No campo da saúde ela, de acordo com este autor, tem três usos principais: etiológico, clínico e administrativo.

Como fase inicial de uma abordagem epidemiológica de violências nos serviços de saúde é fundamental que se possa contar com informações confiáveis, o que dificilmente acontece no caso do Brasil. É preciso que os dados de morbi-mortalidade advindos das situações originárias de violências, bem como dos fatores e comportamentos que levam a riscos aumentados para as pessoas, sejam levantados. Quais seriam as caracteristicas ou circunstâncias, que levam determinados grupos de individuos a terem uma probabilidade de ocorrência de dano à saúde maior que a de outros? Quais desses fatores são identificáveis, observáveis, antes da ocorrência dos acidentes e violências? (CESAR, 1998). 
SCARINGELLA (1999) destaca que na prevenção da violência existem questões vitais, entre elas a de que " a informação precisa ser tratada disponivel e atual. Ela é muito mais do que tabelas e estatisticas. Mais do que um mero banco de dados, deve ser ferramenta de operação dos agentes que intervêm no processo". Ela deve ser obtida de forma ágil e estar à disposição de todas as entidades envolvidas com o problema. "O Sistema de Vigilância Epidemiológica deve se integrar nacionalmente a uma rede de informação rápida e disponível. Assim, será possivel a identificação dos fatores de risco e a partir daí gerenciá-los. Uma ação preventiva da violência é possivel quando há monitoramento".

As principais fontes de dados que podem trazer informações para conhecimento dos agravos à saúde ocasionados por acidentes e violências são:

- Sistema de Informações Hospitalares do Sistema Único de Saúde (SIH/SUS): refere-se às informações já citadas anteriormente, coletadas pelas AIHs. Têm como inconvenientes apenas cobrir a rede SUS, não levando em conta os serviços de saúde privados e ainda ter a finalidade de ser um instrumento de uso administrativo voltado ao faturamento e cobrança da prestação de serviços. Não abrange dados de pronto-socorros;

- Sistema de Informações de Viortalidade do Ministério da Saúde (SIM/MS): dados coletados a partir das declarações de óbito;

- Comunicação de Acidentes de Trabalho/CAT: Sistema de abrangencia nacional, gerido pelo Instituto Nacional de Seguro Social (INSS). É limitado pois exclui categorias de trabalhadores tais como os autônomos, os sem carteira assinada e os vinculados a outros tipos de previdência, como os funcionários públicos;

- Boletim do Departamento Nacional de Estradas de Rodagem (DNER):

Dados referentes a acidentes de trânsito ocorridos em estradas federais, estaduais e municipais;

- Boletim de Ocorrência Policial (BO) Instrumento não-padronizado utilizado nas delegacias de polícia;

- Sistema Nacional de Informações Tóxico-Farmacológicas (SINITOX):

Casos e óbitos por intoxicação humana no país. Abrangência muito pequena.

Esta relação mostra importantes limitações existentes para se reconhecer toda a abrangência dos problemas trazidos à saúde por violências e acidentes. Faltam, entre outras, fontes de informação que permitam a identificação dos eventos cuja gravidade não levam à 
internação ou à morte. Os BO, apesar de úteis, são extremamente limitados, o que não permite a sua utilização de rotina para coleta de informações que possam ser de utilidade no trabalho de promoção, prevenção e recuperação da saúde em causas externas. ANDRADE (1998) encontrou ao estudar acidentes de transporte, uma cobertura média de apenas $22,5 \%$ de registros em $\mathrm{BO}$ de vitimas atendidas em pronto-socorros. As informações diretamente colhidas em prontuários/fichas dos pronto-socorros também são muito pouco úteis para a vigilância e outras atividades pois, geralmente, estes não demonstram coerência entre os diversos profissionais que os preenchem e muito menos quaisquer padronizações para o seu preenchimento. Para os óbitos, apesar dos problemas já apontados, o SIM/MS assegura importantes informações. O mesmo acontece de forma bem mais limitada para os casos de internação, cobertas na rede do Sistema Único de Saúde pelo SIH/SUS.

\section{2- OBJETIVOS}

O estudo piloto busca uma aproximação inicial da realidade, o primeiro contato direto com a população em estudo. Funciona como "um ensaio preparatório da investigação" (SCHLESSELMAN, 1982; ABRAMSON, 1990). Os objetivos de sua realização foram testar a ficha de coleta de dados e verificar sua exeqüibilidade prática, treinar a equipe de entrevistadores, verificar as necessidades de mudanças e acertos de "última hora" que pudessem surgir por imprevistos não imaginados durante o planejamento da pesquisa e para se ter uma idéia do que pudesse ser encontrado.

Os objetivos iniciais do projeto de pesquisa onde se insere este estudo piloto são, em última análise, também seus objetivos:

- contribuir para construção de um sistema de informações para causas externas de morbidade e mortalidade, através de desenvolvimento e validação de ficha de coleta informações em setor de atendimento às urgências e emergências (prontosocorro/ pronto atendimento);

- testar o seu fluxo;

- estudar, a partir dos dados coletados por este instrumento, variáveis relacionadas às vitimas e às circunstâncias destes agravos e lesões e as suas possiveis associações. 


\section{3- Metodologia}

Em uma fase inicial foi elaborado um instrumento para coleta de informações sobre causas externas, no formato de uma ficha. Para sua construção levou-se em conta a referência bibliográfica sobre os agravos pesquisados, seus principais fatores de risco, proteção e ainda, das circunstâncias relacionadas à sua ocorrência e aos atendimentos prestados em serviço de urgência e emergência. Essa ficha foi apresentada a três estudiosos ligados à pesquisas na área de causas externas e a sistemas de informação e vigilância epidemiológica sendo que seu desenho final foi obtido após discussão e crítica. Os tópicos a serem levantados foram colocados no formato de múltipla escolha, sendo que em poucas ocasiões (principalmente nas alternativas “outros. Quais?") estruturados através de questões abertas. A classificação utilizada foi a constante na "Classificação Estatística Internacional de Doenças E Problemas Relacionados à Saúde , Décima Revisão" (Organização Mundial da Saủde, CID-10, 1995).

As variáveis constantes da ficha foram:

- identificação - nome, $\mathrm{n}^{\circ}$ do cartão SUS, endereço, idade, sexo, estado civil e protissão;

- data e hora de entrada no serviço;

- causa - na definição e caracterização da causa seguiu-se a padronização da CID-10 no seu capítulo XX "causas externas de morbidade e mortalidade": acidente de transporte, outras lesões acidentais, lesões autoprovocadas voluntariamente, agressões, outros eventos de intenção indeterminada, intervenções legais e operações de guerra. Complicações de assistência médica e cirúrgica, seqüielas de causas externas de mortalidade e morbidade e fatores suplementares relacionados com as causas de morbidade e mortalidade classificados em outra parte foram agrupados no item “Outros. Quais?” e apresentado como questão aberta. Levandose em conta as referências da literatura indicando eventos de maior ocorrência, os itens especificados na variável "Causa" foram subdivididos de acordo com sua classificação enquanto categoria de três e quatro caracteres de acordo com a CID10. As causas externas de menos encontradas, dentro dos citados padrões de classificação, também foram agregadas como "Outro(a).Qual?";

- avaliação da gravidade da lesão - foram usados dois tipos de escala para tal. Um primeiro baseado na Abreviated Injury Scale, 1990 Revision (AAAM, 1990) com 
seus códigos: minima, moderada, séria, severa, crítica, máxima e desconhecida e outro com a utilização da escala de Glasgow (JENNET, 1972);

- procedimento tomado pelo serviço durante o atendimento ao paciente (orientação, prescrição, sutura, etc.);

- local e momento da ocorrência;

- maneira como o paciente chegou ao serviço;

- destino dado ao paciente após atendimento;

- uma seção dedicada á caracterização das conseqüências das causas externas, utilizando-se com norma classificatória a padronização da CID-10 em seu capitulo XIX ("Lesões, envenenamento e algumas outras conseqüências de causas externas"). Ai foram levantados o número, tipo e localização das lesões e, no caso de intoxicação, a substância que a ocasionou. Outros efeitos de causas externas e os não especificados, algumas complicações precoces de traumatismos, complicações de cuidados médicos e cirúrgicos não classificados em outra parte e seqüelas de traumatismos, intoxicações e outras conseqüências de causas externas foram agrupadas no item "Outras. Quais?". Foi elaborada uma tabela em cujas linhas foram designados os diversos tipos de lesão de acordo com a CID-10 e nas colunas as suas localizações (cabeça, pescoço, tórax, abdome,dorso, pelve, membro superior, membro inferior). Nas células de intersecção entre linhas e colunas, com um numero se assinala então o número de lesões de cada localização;

- em último lugar a ficha registra o horário em que se terminou a coleta dos dados, a data do preenchimento da ficha, nome e assinatura do responsável pelo preenchimento.

Foi selecionado para realização do estudo piloto a unidade de pronto-atendimento municipal da cidade de Pouso Alegre, MG. A população eleita para a coleta de dados se constituiu daqueles pacientes que procuraram o citado serviço - que funciona em regime de plantão de vinte e quatro horas, durante toda a semana - devido a problemas relacionados com causas externas de morbidade e mortalidade durante sete dias do mês de fevereiro de 2003 , durante as vinte e quatro horas de cada dia. No período foram preenchidos os vinte e cinco formulários que foram utilizados no estudo piloto.

Quatro enfermeiras, plantonistas do serviço, primeiramente foram treinadas no preenchimento da ficha de notificação de causas externas, através de discussão e simulações.

Definiu-se que a os dados seriam colhidos a partir das informações obtidas diretamente do paciente e na impossibilidade dele fornecê-las, de seu acompanhante, desde ఈIDliolecajCIR 
que o mesmo fosse familiar ou conhecido do mesmo. Os formulários preenchidos eram imediatamente encaminhados à coordenação da pesquisa, que providenciava sua imediata conferência; no caso de não serem encontrados erros ou dúvidas, eram agregados ao banco de dados, construido a partir do programa de domínio público Epi Info versão 6.04 (DEAN et al, 1994).

Não se procedeu análise estatística uma vez que a amostra utilizada de vinte e cinco indivíduos é insuficiente para se obter significância.

\section{4- RESULTADOS E DISCUSSÃO}

A aplicação prática e a análise do formulário permitiram que fossem constatadas, a partir do trabalho de campo, algumas falhas, dificuldades e até questões omitidas. Como primeira correção a ser feita observou-se a necessidade de uma melhor disposição dos deferentes tópicos pesquisados no layout proposto para a ficha de notificação. Essa alteração ocorreu para que fosse facilitado para os pesquisadores a visualização imediata das dicerentes variáveis que compõem o instrumento testado.

Outro problema foi que a codificação do tipo de causa externa e da lesão foi dificil apenas com as informações constantes do formulário. Para correçã) deste fato propôs-se a introdução de dois novos campos: o primeiro para uma descrição sumária do evento e outro com a mesma finalidade em relação à lesão.

Das vinte e cinco fichas trabalhadas, em dezesseis $(64,0 \%)$ houve o preenchimento do horário de início e término da coleta de dados. Na maior parte constou-se a informação do término $(96,0 \%)$. Nove não assinalaram o horário do início da coleta de dados. Uma ficha que não assinalou nem o horário de início, nem o do término. Esses erros ocorreram do preenchimento efetuado por duas das pesquisadoras, o que demonstrou a necessidade de reforçar seu treinamento neste tópico. Como "horário do início da coleta" se trata do primeiro quesito da ficha de notificação, também é necessário que o item seja melhor destacado graficamente. A média de tempo gasto com o preenchimento do questionário foi de oito minutos cinquienta e quatro segundos, dentro de um intervalo que variou entre três e quinze minutos. A moda foi preencher em cinco minutos $(31,3 \%)$ dos preenchimentos. A mediana do preenchimento foi com oito minutos. Uma demora de quatro ou de dez minutos vieram a seguir com respectivamente $18,8 \%$ das ocorrências referentes a tempo de preenchimento (figura 1). $\mathrm{O}$ tempo utilizado pode ser considerado razoável tendo em vista se tratarem das primeiras experiências de preenchimento dentro da dinâmica de uma rotina de serviços de 
pronto atendimento onde não podem ocorrer demoras, pela urgência das necessidades dos pacientes.

\section{Figura 1}

Tempo gasto (minutos) no preenchimento de fichas de notificação no Pronto

Atendimento Municipal de Pouso Alegre, MG, em fevereiro de 2003

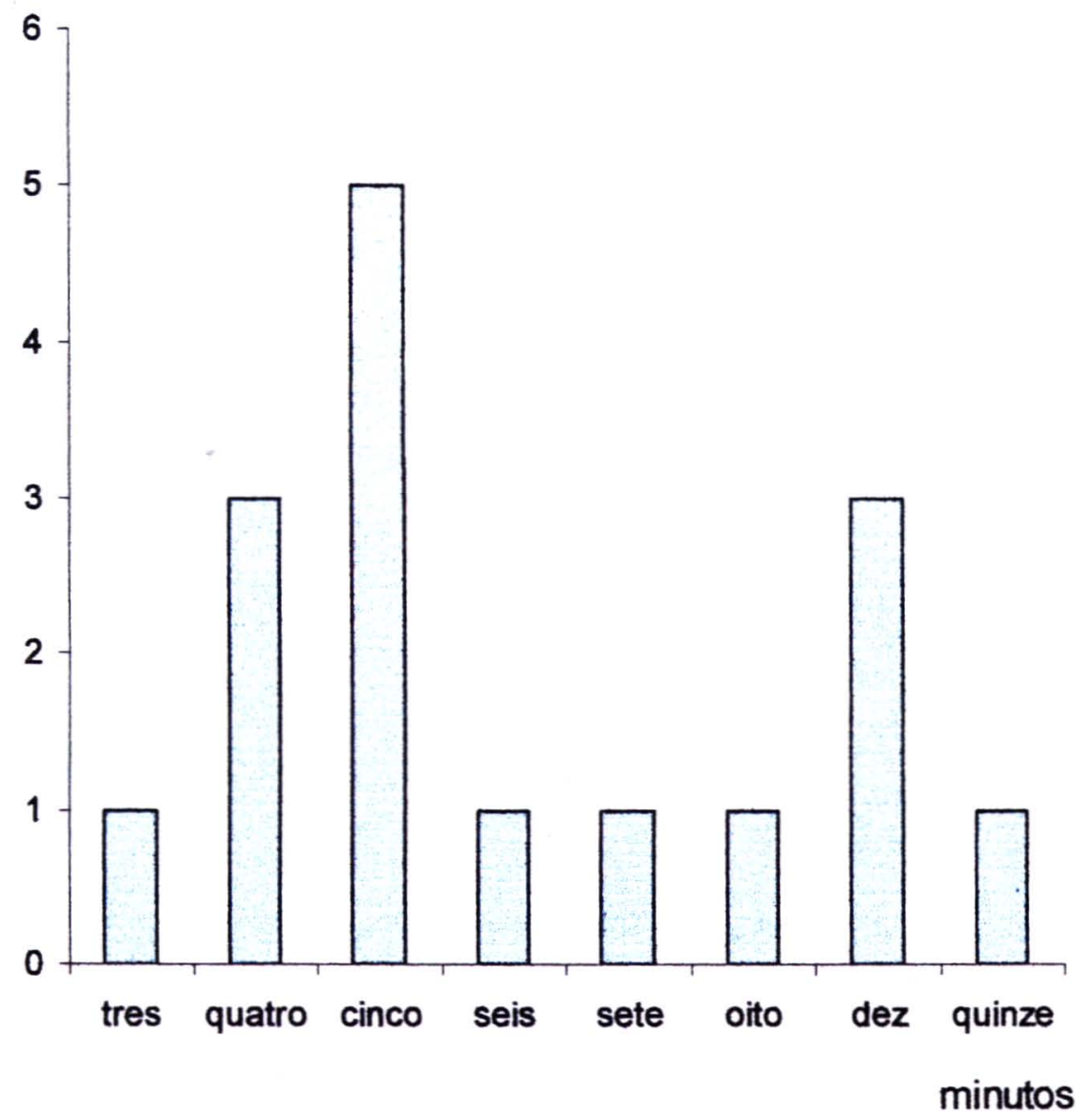

O preenchimento dos dados de identificação dos pacientes ocorreu em $100,0 \%$ dos formulários, ressalvando-se o item endereço que não constou de quatro fichas, do item idade em uma destas e o item profissão que não foi apresentado em onze fichas. Entretanto é importante ressalvar que profissão é um quesito que não se aplica a alguns casos. Foi o que aconteceu no não preenchimento de sete formulários de menores de cinco anos e em um formulário de um provável aposentado com cerca de sessenta e oito anos. Nesta perspectiva, apenas três fichas não-preenchidas estariam omitindo informações. Foram registradas as seguintes profissões:

- agricultor 02

- aposentado 01

- auxiliar de produção 01 
- balconista 01

- comerciário 01

- costureira 01

- do lar 01

- estudante 01

- motorista 01

- operador de máquinas 01

- pedreiro 01

- total 14

Pelo pequeno tamanho da amostra não se pôde concluir quais as profissões mais afetadas por problemas de saúde ocasionados por causas externas, o que também não se trata de objetivo deste estudo piloto.

A maioria dos pacientes foi do sexo masculino (72.0\%). A distribuição etária pode ser vista na tabela 1:

Tabela 1

Distribuição etária dos pacientes atendidos devido a causas externas no Pronto Atendimento Municipal de Pouso Alegre, MG, em fevereiro de 2002

\begin{tabular}{|c|c|c|c|c|c|c|c|c|c|c|}
\hline & $\begin{array}{l}\text { Menos } \\
\text { de um } \\
\text { ano }\end{array}$ & $\begin{array}{l}1 \mathrm{a} 4 \\
\text { anos }\end{array}$ & $\begin{array}{l}5 \text { a } 9 \\
\text { anos }\end{array}$ & $\begin{array}{c}10 \text { a } 14 \\
\text { anos }\end{array}$ & $\begin{array}{c}15 \text { a } 19 \\
\text { anos }\end{array}$ & $\begin{array}{c}20 \text { a } 29 \\
\text { anos }\end{array}$ & $\begin{array}{c}30 \text { a } 39 \\
\text { anos }\end{array}$ & $\begin{array}{c}40 \text { a } 49 \\
\text { anos }\end{array}$ & $\begin{array}{l}50 \mathrm{e} \\
\text { mais } \\
\text { anos }\end{array}$ & Ignorad \\
\hline ímero & - & 5 & 4 & 3 & - & 1 & 7 & - & 4 & 1 \\
\hline $\begin{array}{l}\text { rcen- } \\
\text { gem }\end{array}$ & - & $20,0 \%$ & $16,0 \%$ & $12,0 \%$ & - & $4,0 \%$ & $28,0 \%$ & - & $16,0 \%$ & $4,0 \%$ \\
\hline
\end{tabular}

Cerca de $48,0 \%$ dos pacientes tinha menos de vinte anos de idade. Não foi obtida a idade de um indivíduo, que não soube informar.

A data de entrada foi preenchida em $100,0 \%$ das fichas de notificação. A hora foi preenchida em vinte e quatro formulários. 
Das vinte e cinco fichas, apenas uma não registrou a causa do agravo que levou o indivíduo a procurar o serviço. Das vinte e quatro que informaram 54,2\% (treze casos) eram "outras lesões acidentais". 25,0\% (seis casos) "agressões" e 20,8\% (cinco casos) "acidentes de transporte". Das classificadas como "outras lesões acidentais" 38,5\% eram quedas e $61,5 \%$ eram outras lesões. Essa grande percentagem do item "outras" e a ausência dos demais itens listados no instrumento levaram à avaliação de que este tópico necessitava de um maior número de opções, uma vez que nos oito casos assim assinalados houve uma picada de inseto, três mordeduras por cão, três contatos com objetos cortantes e um contato com objeto contundente. Por estas razões fez-se necessária a revisão do instrumento de coleta de dados. Dois acidentes de transporte foram erroneamente classificados como "outras lesões acidentais", uma queda de bicicleta e uma colisão, o que foi corrigido. Houve uma certa confusão no tópico "descrição do evento" constante do item "outras lesões acidentais" pois em três formulários referentes a outras causas externas foi feita a descrição neste local. Este fato demonstrou a importância da introdução de dois novos campos no questionário que abordassem de forma descritiva tanto as características da causa externa bem como das lesões ocasionadas.

Entre os acidentes de transporte registrou-se 40,0\% de quedas de ticicleta, $40,0 \%$ de colisões e $20,0 \%$ de atropelamentos. Destes cinco eventos dois envolveram ciclistas, dois motociclistas e um motorista/passageiro de automóvel, caminhonete, caminhão ou ônibus. Esse item não apresentou erros ou dificuldades ao preenchimento. As colisões que surgiram aconteceram entre um automóvel e um caminhão e entre uma motocicleta e um automóvel. É importante ressaltar que os diversos tópicos constantes da variável acidente de trânsito não apresentaram dificuldades no preenchimento.

Foram registradas seis agressões: $50,0 \%$ (três ocorrências) por objeto contundente, $33,3 \%$ (duas ocorrências) por objeto cortante e 16,7\% (uma) por força corporal. Quanto ao preenchimento, este também foi um tópico que não apresentou problemas.

Os campos "lesões autoprovocadas voluntariamente", "outros eventos de intenção indeterminada", "intervenções legais e operações de guerra" e "outros" não apresentaram nenhuma ocorrência no periodo do estudo piloto.

Um problema complexo se revelou no preenchimento do campo "avaliação da gravidade da lesão". Não se conseguiu chegar a uma padronização referente à classificação utilizada, com uma definição que sintetizasse as avaliações "leve", "moderada", "severa", pois a Abreviated Injury Scale, 1990 Revision (AAAM, 1990) é um instrumento muito 
complexo, com grandes dificuldades de aplicação e ainda, não tem versão em português. Em um ambiente de pronto-socorro, voltado para urgência e emergência, o tempo despendido com formulários não pode se alongar para que não ocorra prejuizo ao atendimento. Além disso o preenchimento desta ficha está sendo proposto como uma atividade que possa envolver pessoal de nivel médio e não somente profissionais de terceiro grau com certo nível de especialização. O que acabou ocorrendo foi a utilização de critérios totalmente subjetivos ao se realizar este preenchimento fato que invalidou os resultados aí obtidos. Diante desta situação foi proposta a retirada deste item da ficha de coleta de dados com a manutenção exclusiva da escala de Glasgow (JENNET, 1974) que apresenta objetividade, simplicidade, uso consagrado em nosso meio e por se tratar de instrumento que se encontra validado no idioma português. Todos os pacientes que foram estudados tinham Glasgow menor que oito, ou seja, nenhum se encontrava em coma. A utilização desta escala deve ser melhor avaliada pois neste tipo de serviço, de atendimento às urgências, dificilmente surgirão pacientes com um quadro comatoso.

O serviço realizou cinqüenta e seis procedimentos nos vinte e cinco pacientes estudados sendo que $64,0 \%$ deles receberam orientação, $60,0 \%$ prescrição, $64,0 \%$ limpeza e curativo, 28,0\% foram submetidos a sutura e 4,0\% outros pruceciımentos (vacinação). Nenhum paciente deixou de receber algum tipo de procedimento nem houve registro de que algum deles tenha recebido imobilização. Esse item não revelou problemas na aplicação durante o estudo piloto.

No preenchimento do item "local e momento de ocorrência" aconteceram apenas dois preenchimentos incorretos. O entrevistador assinalou a opção "outros" em duas das fichas quando a opção correta era "residência". No primeiro caso porque se tratava não da residência própria mas da vizinha e no segundo no quintal de sua própria residência. $O$ aparecimento destes erros foi importante pois se tratava de situação ainda não prevista na padronização do preenchimento do questionário e nem no treinamento dos entrevistadores. A tabela 2 mostra os locais onde aconteceram as causas externas estudadas. É importante frisar que $80,0 \%$ dos eventos ocorreu ou na residência da vítima ou em suas imediações. Principalmente quando estes episódios envolviam crianças.

Houve um atendimento discretamente maior na sexta, sábado e domingo do que nos demais dias e o horário de maior freqüência de atendimentos foi o de 12:00 às 18:00 h que concentrou 48,0\% das ocorrências. Apenas em uma ficha não houve informação relativa a dia e a hora. 
Das vitimas que informaram o local de ocorrência $22,7 \%$ aconteceram no bairro São João e $22,7 \%$ no São Geraldo. Estes são os bairros mais populosos de Pouso Alegre e ainda os de maior concentração de população de baixa renda o que pode justificar esses resultados.

\section{Tabela 2}

Local da ocorrência das causas externas de lesão em pacientes do Pronto Atendimento de Pouso Alegre, MG, em fevereiro de 2003

\begin{tabular}{|c|c|c|}
\hline LOCAL & Nủmero & Percentagem \\
\hline Residência & 10 & $40,0 \%$ \\
\hline Escola & - & - \\
\hline Área para prática de esportes & - & - \\
\hline Rua & 10 & $40,0 \%$ \\
\hline Estrada & - & - \\
\hline Local de trabalho & 2 & $8,0 \%$ \\
\hline Área de comércio e serviços & - & - \\
\hline $\begin{array}{l}\text { Área industrial ou em } \\
\text { construção }\end{array}$ & - & - \\
\hline Zona rural & 3 & $12,0 \%$ \\
\hline Outros & - & - \\
\hline Total & 25 & $100 \%$ \\
\hline
\end{tabular}

O quesito que informa a maneira como o paciente chegou ao Pronto Atendimento foi preenchida na totalidade das fichas estudadas sem erros ou quaisquer problemas:

- $56,0 \%$ de carro próprio;

- $24,0 \%$ a pé;

- $12,0 \%$ trazidos pela polícia

- $4,0 \%$ de ambulância e

- $4,0 \%$ de ônibus. 
Vinte e dois receberam alta após o atendimento e três foram encaminhados para internação. Não houve óbitos neste período.

As últimas informações coletadas através da ficha de notificação de causas externas de morbidade e mortalidade foram as referentes ao tipo de lesão apresentada e sua localização. $O$ preenchimento do quadro construido para este tópico não ocasionou dúvidas de monta. Apenas, em alguns poucos formulários houve preenchimento não com números, conforme especificado na metodologia, mas através de simples marcação da célula adequada com um " $\mathrm{x}$ " (seis fichas). Nos vinte e cinco individuos estudados assinalou-se um total de trinta $\mathrm{e}$ nove lesões com uma média de 1,6 por paciente. Na população estudada, aquele que apresentou maior número teve seis diferentes lesões, dentro de um único evento. A moda foi uma lesão por acidente ou violência, o que foi verificado em dezessete pessoas. Além disto, seis das vítimas das causas externas tinham duas lesões e uma, quatro. Acidentes de transporte foram responsáveis por $38,5 \%$ das lesões, outras causas acidentais por $41,0 \%$ e agressões por 17,9\%.e 2,6\% sem causa definida. A média de lesões, por pessoa, ocasionadas por acidentes de transporte foi a mais alta (três lesões por acidentado), seguida de outras causas acidentais com 1,2 e agressões com 1,1 . As mais registradas foram ferimentos $(66,7 \%)$ vindo a seguir traumatismos superficiais $(20,5 \%)$; luxações, distensões e entorscs $(10,3 \%)$ e corpo estranho $(2,6 \%)$. Não ocorreram no período estudado intoxicações, fraturas nem outras conseqüências de causas externas. Os locais mais atingidos foram respectivamente: em primeiro lugar os membros superiores com $35,9 \%$ das ocorrências, em seguida veio cabeça e membros inferiores com $28.2 \%$. Foi relatada apenas uma lesão $(2,6 \%)$ em abdome e pelve e não se relatou problemas localizados em pescoço, tórax e dorso. Não se determinou o local de uma lesão. A tabela 3 relaciona local e tipo da lesão. É interessante notar que os membros inferiores e superiores portaram um maior número de ferimentos e as lesões localizadas na cabeça têm uma distribuição equilibrada entre traumatismos superficiais e ferimentos. Acidentes de transportes ocasionaram, entre as trinta e nove lesões estudadas, dois traumatismos superficiais $(5,1 \%)$ e treze ferimentos $(33,3 \%)$; outras lesões acidentais quatro traumatismos superficiais $(10,3 \%)$, sete ferimentos $(18,0 \%)$ e quatro luxações, entorses e/ou distensões $(10,3 \%)$; agressões ocasionaram dois traumatismos superficiais $(5,1 \%)$ e cinco ferimentos $(15,3 \%)$. Houve um ferimento de causa desconhecida $(2,6 \%)$. Proporcionalmente, foram os acidentes de transporte os causadores do maior número de lesões de mais graves. Se forem tomados como base os achados deste estudo piloto, os acidentes de transporte foram entre os eventos estudados, os de maior gravidade. 
Tabela 3

Localizações e tipos de lesões ocasionadas por causas externas em pacientes do Pronto Atendimento Municipal de Pouso Alegre, MG, em fevereiro de 2003

\begin{tabular}{|c|c|c|c|c|c|c|c|c|c|}
\hline & Ignorado & Cabeça & Pescoço & Tórax & Abdome & Dorso & Pelve & $\begin{array}{l}\text { Membro } \\
\text { superior }\end{array}$ & $\begin{array}{l}\text { Membro } \\
\text { inferior }\end{array}$ \\
\hline $\begin{array}{l}\text { Traumatismo } \\
\text { superficial }\end{array}$ & 1 & 6 & - & - & - & - & - & 1 & - \\
\hline Ferimento & - & 5 & - & - & 1 & - & 1 & 12 & 7 \\
\hline $\begin{array}{l}\text { Luxação } \\
\text { entorse } \\
\text { distensão }\end{array}$ & - & - & - & - & - & - & - & 1 & 3 \\
\hline $\begin{array}{l}\text { Traumatismos } \\
\text { nervos e } \\
\text { medula } \\
\text { espinhal }\end{array}$ & - & - & - & - & - & - & - & - & - \\
\hline $\begin{array}{l}\text { Traumatismo } \\
\text { vasos } \\
\text { sangüineos }\end{array}$ & - & - & - & - & - & - & - & - & - \\
\hline $\begin{array}{l}\text { Traumatismo } \\
\text { tendões e } \\
\text { músculos }\end{array}$ & - & - & - & - & - & - & - & - & - \\
\hline $\begin{array}{l}\text { Traumatismos } \\
\text { órgãos } \\
\text { internos }\end{array}$ & - & - & - & - & - & - & - & - & - \\
\hline $\begin{array}{l}\text { Lesões por } \\
\text { esmagamento }\end{array}$ & - & - & - & - & - & - & - & - & - \\
\hline $\begin{array}{l}\text { Corpo } \\
\text { estranho }\end{array}$ & - & - & - & - & - & - & - & - & 1 \\
\hline Queimaduras & - & - & - & - & - & - & - & - & - \\
\hline Total & 1 & 11 & - & - & 1 & - & 1 & 14 & 11 \\
\hline
\end{tabular}

As lesões ocasionadas por acidentes de transporte atingiram preferencialmente os membros superiores, já as ocasionadas por outras lesões acidentais tiveram uma preferência proporcionalmente semelhante para membro inferior e cabeça. No caso das agressões a região mais afetada também foi a dos membros superiores.

Um ponto importante foi que se detectou que a entrada proposta para o banco de dados não deu conta de toda a demanda de cruzamentos que podem ser pesquisados a partir das informações coletadas e que, portanto, faz-se necessária uma reformulação da sua estrutura. 


\section{5- CONCLUSÕES}

O presente estudo piloto foi importante para se comprovar que serviços de urgência são fontes extremamente úteis na coleta de dados sobre causas externas e também para que fatores ligados à gênese e ocorrència destes eventos fiquem perdidos pela inexistência de um sistema de informações adequado. Neste caso foi trabalhada uma amostra de apenas vinte e cinco indivíduos, não se podendo, portanto, aferir a significância estatística do mesmo. Entretanto, foi possivel obter-se uma boa visão a respeito do universo a ser explorado. Verificou-se a viabilidade da utilização do instrumento no ambiente de atenção à urgência e à emergência, sem que a ficha constituisse fator limitante aos trabalhos de atendimento e ainda sem causar transtornos à sua rotina. A partir do estudo piloto foram levantadas as seguintes necessidades de reestruturação no instrumento e no trabalho de campo:

- modificação do layout da ficha de coleta de dados através do aperfeiçoamento de seu desenho inclusive com a colocação de algumas questões numa nova ordem e introdução de alguns tópicos novos;

- introdução de tópicos descritivos da causa externa e do agravo atendido;

- rediscutir os itens que os pesquisadores tiveram maior dificuldade e introduzir manual de instruções, como garantia de incrementar sua validade interna;

- ampliação do número de opções constantes do item "outras lesões acidentais" que se encontrava incompleto e sem preencher as necessidades de informação;

- introdução de campos para descrição da lesão e da sua causa externa na busca de uma maior acurácia do dado coletado e da ampliação de seu valor preditivo positivo;

- a introdução destes novos campos pode ter a conseqüência de ampliar a validade de conteúdo do instrumento;

- efetuar a definição de padrão-ouro, que por exemplo poderá ser o preenchimento do mesmo instrumento concomitantemente por um especialista, a partir do qual poder-se-á chegar aos valores de especificidade, sensibilidade, valores preditivos positivo e negativo;

- suspender o item destinado a se determinar a avaliação da gravidade do evento por não se dispor de escala que se prestasse à aplicação em ambiente de pronto-socorro. Utilizar como alternativa a escala de Glasgow e combiná-la com medidas indiretas tais como tipo da lesão, destino do paciente, procedimento tomado; 
- redesenho das entradas para o banco de dados para que se permita uma análise adequada quando se for trabalhar com amostras maiores;

- assegurar a validade externa deste instrumento trabalhando-se com todo o universo de usuários dos serviços de urgência e emergência.

A maior parte dos individuos vítimas de causas externas foi do sexo masculino (72\%) o que se assemelha ao achado do estudo do MMWR (2001) na base de dados NEISS-AIP (National Electronic Injury Surveillance Syatem: All Injury Program), que constatou que a incidência de lesões é $40,0 \%$ maior em homens do que em mulheres. A faixa etária mais atingida foi a dos de menos de vinte anos de idade, o que também apresenta concordância com o já citado estudo. Na maior parte das vezes os acidentes e violências aconteceram na residência do paciente ou nas imediações desta, principalmente em bairros populosos e de baixa renda.

Os dias da semana com maior número de ocorrências foram os do fim-de-semana, que correspondem a um periodo onde há maior freqüência de atividades nas ruas e um consumo aumentado de bebidas alcoólicas, conhecido fator de risco para ocorrência de problemas ligados às causas extern : rerca de $16,0 \%$ dos pacientes necessitaram de internação e não se registrou nenhum óbito. Tal pode ser justificado pelo fato do serviço estudado, de pronto atendimento, lidar, normalmente, com urgências de menor gravidade, que geralmente não vão necessitar de cobertura hospitalar (internação, cirurgia ou terapia intensiva).

O tipo de lesão de maior ocorrência foram os ferimentos $(66,7 \%)$ e "outras causas acidentais" foram as causas externas mais comuns. O tipo de evento que gerou conseqüências de maior gravidade foram os "acidentes de transporte". As regiões do corpo mais atingidas foram respectivamente membros superiores, membros inferiores e cabeça. Os membros superiores e os inferiores foram afetados por lesões de maior gravidade. Os membros superiores sofreram lesões principalmente resultantes de acidentes de transporte e de agressões, já nos membros inferiores e cabeça foram originados agravos, em primeiro lugar, por outras causas acidentais. 


\section{6- REFERÊNCIAS BIBLIOGRÁFICAS}

ABRAMSON, J.H. - Survey methods in community medicine. 4.ed. New York, Churchill Livingstone, 1990. 339p.

ANDRADE, S.M. - Acidentes de transporte terrestre em Londrina - Paraná: análise das vitimas. dos acidentes e das fontes de informação. . São Paulo, 1998. [ Tese

- Doutorado - Faculdade de saúde Pública - Universidade de São Paulo].

ASSOCIATION FOR ADVENCEMENT OF AUTOMOTIVE MEDICINE - The abbreviated injury scale -1990 revision. Des Planes, AAAM, 1990. 74 p.

CÉSAR, C. G. L. - O 'enfoque de risco' em saúde pública. In: BARRETO, M.L.; ALMEIDA F.', N.; VERAS, R.P.; BARATA, R.B. - Epidemiologia, serviços e tecnologias em saúde. Rio de Janeiro, FIOCRUZ/ABRASCO, 1998. p. 79-92.

DEAN A.G.; DEAN, J.A.; COULOMBIER, D.; BRENDEL, K.A.; SMITH, D.C.; BURTON, A.H.; DICKER,R.C.; SULLIVAN, K.; FAGAN, R.F.; ARNER, T.G.; - Epi-info Version 6: a word processing database and statistics program for epidemiology microcomputers. Atlanta, Centers for Disease Control, 1994. p. 73-81.

DEVER, G.E.A. - A epidemiologia na administração dos serviços de saúde. 1 ed. São Paulo, Pioneira, 1988.

JENNET B., TEASDALE G., BRAAKMAN R., MINDERHOUD J., KNILLJONES R. - Predicting outcome in individual patients after severe head injury Lancet 1:1031-1034, 1974

MÉDICI, A. C. - As raizes econômicas da violência e seus impactos na saúde. Saúde em Debate, 34: 40-6, 1992.

MORDIBITY AND MORTALITY WEEKLY REPORT (MMWR). - National estimates of nonfatal injuries treated in hospital emergency departments United States, 2000. MMWR 50: 340-6. 2001.

ORGANIZAÇÃO MUNDIAL DA SAÚDE (OMS) - Classificação estatística internacional de doenças e problemas relacionados à saúde, décima revisão. 2.ed. São Paulo, EDUSP, 1995. 1191p.

ORGANIZACION MUNDIAL DE LA SALUD (OMS); ORGANIZACION PANAMERICANA DE LA SALUD (OPAS) - Volencia y salud. Tema 4.12 del programa provisional. In: Reunión del Comité Ejecutivo del Consejo Directivo (OPAS) y el Grupo de Trabajo del Comité Regional(OMS) 111.a, Washington, D.C., CE111/19 (Esp.). Washington, D.C., OPAS, 1993 a. P. 1-17.

ORGANIZACION MUNDIAL DE LA SALUD (OMS);ORGANIZACION PANAMERICANA DE LA SALUD (OPAS) - Resolucion XIX de $10^{\circ}$ de octubre de 1993: Violencia y Salud, Washington, D.C., p 1-3, 1993 b. 
RIPSA - REDE INTERAGENCIAL DE INFORMAÇƠES PARA A SAÚDE Indicadores básicos para a saúde no Brasil: conceitos e aplicações. 1 ed. Brasilia. Organização Panamericana de Saúde (OPAS), 2002. 299 p.

SCARINGELLA, R. S.- Debatedor: É possivel prevenir a violência? Reflexões a partir do campo da saúde pública. Ciência e Saúde Coletiva 4: 28-9. 1999.

SCHLESSELMAN, J.J. - Case-control studies - Design, conduct, analysis. 1.ed. New York, Oxford University Press, 1987. p. 90-104.

WALDMAN. E. A.: MELLO JORGE, M. H. P. - Vigilância para acidentes e violência. . Ciência e Saúde Coletiva 4: 71-9. 1999.

\section{RESUMO}

Causas externas são dos mais relevantes problemas de saúde no Brasil e no mundo. Tratamse de agravos à saúde que muitas vezes atingem extrema gravidade, sendo importantes causas de morte. incapacidade e sofrimento, e ainda, se encontram entre os maiores causadores de morbi-mortalidade nas faixas mais jovens da população. Entretanto, não existem na rotiia dos serviços de saúde em nosso país instrumentos yue permitam a estruturação de sistema de informação que possibilite um melhor conhecimento e ação sobre estes agravos.

Este estudo piloto pretende ser um contato inicial com a realidade a ser pesquisada, o primeiro contato direto com a população em estudo. Funciona como "um ensaio preparatório da investigação" na busca de se validar uma ficha de coleta de dados sobre causas externas de lesão em serviços de urgència e emergência para contribuição para a estruturação de sistema de informações sobre esses problemas de saúde. Visa também levantar algumas informações sobre as vitimas e circunstâncias das causas externas.

Foi elaborada ficha de coleta de dados que foi aplicada em 25 pacientes do serviço de pronto-atendimento municipal de Pouso Alegre, MG por quatro enfermeiras plantonistas no final de fevereiro de 2003. Os dados coletados passaram por critica e foram agrupados em banco de dados construído utilizando-se o programa Epi-Info 6.4.

Não se pôde ałerir a significância estatística pelo pequeno tamanho da amostra, mas conseguiu-se uma boa visão a respeito do universo a ser explorado, verificou-se a viabilidade da utilização do instrumento no ambiente de atenção à urgência e à emergência, sem causar transtomos à sua rotina. Os principais achados do estudo foram: 
A maior parte dos indivíduos pesquisados foram do sexo masculino e de menos de vinte anos. Na maior parte das vezes os acidentes e violências aconteceram na residência do paciente ou nas imediações desta, principalmente em bairros populosos e de baixa renda. Os dias da semana com maior número de ocorrencias foram os do fim-de-semana. Cerca de $16,0 \%$ dos pacientes necessitaram de internação e não ocorreu nenhum óbito. O maior número de lesões registradas foram ferimentos $(66,7 \%)$ e outras causas acidentais foram as causas externas mais comuns. $O$ evento que gerou conseqüências de maior gravidade foram os acidentes de transporte. As regiões do corpo mais atingidas membros superiores, membros inferiores e cabeça. Os membros superiores e os inferiores foram afetados por lesões de maior gravidade.

Quanto a achados relativos ao instrumento verificou-se : necessidade de introdução de campos para codificação da causa externa e da lesão e modificação do desenho da ficha; introduzir manual de instruções, como garantia de incremento de sua validade interna; a introdução de campos em que se descrevesse a lesão e a causa externa para ampliação de seu valor preditivo positivo; a introdução destes novos campos para a ampliação da validade de conteúdo do instrumento; necessidade do estabelecimento de padrão-ouro; utilizar apenas a escala de Glusguw na determinação da gravidade do eventก. 
ANEXO 3 


\section{DAdOS A RESPEITO DO MUNICIPIO DE POUSO ALEGRE, MINAS GERAIS}

Pouso Alegre é um município situado na região sul do Estado de Minas Gerais, com uma área de 544 quilòmetros quadrados e uma infra-estrutura de boa qualidade (tabela 1).

Com uma economia basicamente voltada para a produção industrial, apresenta centenas desses estabelecimentos entre pequenas, médias e grandes indústrias. Pouso Alegre é uma cidade com população de 106.776 habitantes (IBGE, 2002). É um polo industrial e multisetorizado. Ali convivem empresas multinacionais e brasileiras de grande porte com inúmeras outras pequenas e médias indústrias, dos diversos segmentos. A economia municipal se estrutura à base de 700 unidades industriais, 1.500 unidades agropecuárias e mais de $\mathbf{4 . 0 0 0}$ unidades comerciais e de serviço.

Pouso Alegre tem desenvolvido um modelo de industrialização, fortemente orientado para a incorporação de tecnologias seletivas (eletrônica, telecomunicações. mecatrônica. bioengenharia e outras). Energia: transporte; telecomunicações: aeroporto com linhas regulares diárias conectadas com Rio, São Paulo, Ẽu Horizonte. escolas: hospitais e clinicas; hoteis, opções de lazer. enfim, há todo um conjunto de condições de infra-estrutura.

Sua posição geográfica é, estrategicamente, conveniente pois a situa de forma eqüidistante, em relação aos grandes centros consumidores do país. Está às margens da Rodovia Fernão Dias. 
Tabela 1 - Alguns resultados do censo de 2000 para Pouso Alegre, MG.

\begin{tabular}{|c|c|c|}
\hline Categoria - ano & & mero \\
\hline Pessoas residentes -2000 & 106.776 & habitantes \\
\hline Homens residentes - 2000 & 52.715 & habitantes \\
\hline Mulheres residentes -2000 & 54.061 & habitantes \\
\hline $\begin{array}{l}\text { Pessoas residentes - } 10 \text { anos ou mais de idade - } \\
\text { alfabetizada - } 2000\end{array}$ & 83.006 & habitantes \\
\hline Pessoas residentes - 60 anos ou mais de idade & 8.978 & habitantes \\
\hline Domicílios particulares permanentes & 29.455 & domicilios \\
\hline $\begin{array}{l}\text { Domicílios particulares permanentes - forma de } \\
\text { abastecimento de água - rede geral }\end{array}$ & 26.524 & domicílios \\
\hline $\begin{array}{l}\text { Domicílios particulares permanentes - forma de } \\
\text { abastecimento de água - poço ou nascente }\end{array}$ & 2.823 & domicilios \\
\hline $\begin{array}{l}\text { Domicilios particulares permanentes - forma de } \\
\text { abastecimento de água - outras formas }\end{array}$ & 108 & domicílios \\
\hline $\begin{array}{l}\text { Domicílios particulares permanentes - com banheiro } \\
\text { ou sanitário }\end{array}$ & 29.289 & domicílios \\
\hline $\begin{array}{l}\text { Domicílios particulares permanentes - com banheiro ou } \\
\text { sanitário - esgotamento sanitário - rede geral }\end{array}$ & 25.667 & domicílios \\
\hline $\begin{array}{l}\text { Lomicilios particulares permanentes - sem banheiro ou } \\
\text { sanitário }\end{array}$ & 166 & domicilios \\
\hline $\begin{array}{l}\text { Domicilios particulares permanentes - destino de lixo - } \\
\text { coletado }\end{array}$ & 27.522 & domicilios \\
\hline $\begin{array}{l}\text { Domicílios particulares permanentes - destino de lixo - } \\
\text { outro destino }\end{array}$ & 1.933 & domicílios \\
\hline
\end{tabular}

Fonte: IBGE. Censo Demográfico 2000 - Malha Municipal Digital do Brasil 1997

Nas últimas décadas a cidade, de características eminentemente rurais nos anos 60 . passa por processo acelerado de urbanização e industrialização. Concomitantemente, o contingemte populacional também apresenta grande crescimento. Em 1960 a população total era de 27.763 habitantes, dos quais 18.852 na zona urbana e 8.911 na zona rural (IBGE, 1962); em 1970 a população já apresentava 38.072 individuos dos quais 8.864 rurais. O censo de 1991 contabilizou 81.936 moradores; desses, 7.514 pessoas ainda viviam no campo (IBGE, 1992). A contagem da população de 1996 indicou uma população de 93.166 (IBGE, 1997). O censo de 2.000 revelou uma população residente de 106.776 individuos 2002, disponivel na Internet em http://wwwl.ibge.gov.br/home/estatistica/populacao/censo2000/universophp?tipo=31\& paginaatual=1\&uf=31\&letra=P em 11/05/2003). O crescimento populacional foi, nesses 40 anos, de $284,6 \%$. Entre 1960 e 2.000 a zona urbana apresentou um acréscimo populacional 
de $418,6 \%$ e a população rural aumentou apenas $1,8 \%$. A população urbana, que em 1960 era 2,1 vezes maior que a rural; passou a ser 10,8 vezes, em 2.000 .

A economia. até então centrada na agricultura do café, da batata e da pecuária leiteira, deu lugar a atividades industriais, nas últimas décadas. A localização estratégica próxima aos mercados consumidores de Belo Horizonte, São Paulo e Rio de Janeiro, as vantajosas condições oferecidas pelo poder local, e ainda a busca de novos locais para funcionamento das indústrias paulistas, para lugares onde os trabalhadores fossem menos organizados e pouco reivindicantes, fizeram com que Pouso Alegre, a partir dos anos 70, se tornasse um polo de atração. Apresenta também importante atividade na produção de morango.

Nesse periodo a cidade também iniciou a formação de uma importante rede de ensino superior, com o surgimento das faculdades de medicina, direito, e filosofia. Ao mesmo tempo atividades comerciais de âmbito regional se estruturaram. Em 1999 é criada a Universidade de Pouso Alegre que congrega todos os cursos de terceiro grau no município, excetuando-se o $c:$ du eito.

Por apresentar todas essas características, Pouso Alegre é uma cidade que apresenta grande movimento de pessoas e, conseqüentemente intenso trânsito de veículos a motor. Essa situação reflete-se em congestionamentos em certos horários de maior movimentação de veículos. $O$ município se situa no entroncamento de algumas das mais movimentadas rodovias do Estado de Minas Gerais. Ai se cruzam a BR 381 (rodovia Fernão Dias), que atravessa o Estado ligando São Paulo a Belo Horizonte e a BR 459 que liga a via Presidente Dutra (São Paulo-Rio de Janeiro) a Poços de Caldas, passando pela importante cidade de Itajubá e dando acesso ao "circuito das águas". Estradas estaduais de porte também são parte da malha viária de Pouso Alegre: a MG 179 (Pouso Alegre - Alfenas) e a MG 290 que propicia acesso do sul de Minas à importante região de Campinas, no Estado de São Paulo. O tráfego é, portanto, intenso, tanto em região urbana como rural. Além disso, devido a essa localização e por suas características econômicas a cidade vem apresentando crescimento desordenado, o que provoca como conseqüência um substancial aumento das violências e acidentes, principalmente os de trânsito.

Pouso Alegre tem 25 serviços municipais de atenção primária à saúde. A rede hospitalar é composta por quatro estabelecimentos; um pertencente à Universidade local, 
que é o responsável pelo atendimento dos pacientes do Sistema Único de Saúde (SUS), além de três hospitais privados de pequeno porte. O hospital universitário é o único que apresenta estrutura para atenção a pacientes graves, em situações de emergência. Possui pronto-socorro (PS) para atendimento exclusivo a emergências, UTI, laboratórios, salas de cirurgia, serviços de radiologia, médicos e paramédicos 24 horas por dia. A partir de fevereiro de 2003 passa a contar também com serviço municipal de pronto-atend imento que centraliza a atenção às urgências do município. Trabalha basicamente com agravos que não exijam um periodo de permanência superior a 24 horas e que não necessitem de suporte de centro cirúrgico ou unidade de tratamento intensivo, sendo que os casos que se enquadram nestas categorias são encaminhados para o hospital universitário (tabela 3).

SILVA, ANDRADE, LEAL (1993) encontraram, em Pouso Alegre, 74 óbitos por causas externas de lesão. Desses, $34,4 \%$ foram causados pelos acidentes de trânsito. Nesses óbitos foram incluídos os não-residentes na cidade. MESQUITA FILHO, CASTRO, RAVANINI, OLIVEIRA. LIMA (1995), estudando os óbitos de residentes em Pouso Alegre no periodo de 1979 a 1992 . verificaram que a mor cude por causas externas, que era em 1979 era a terceira mais importante, entre 1980 e 1985 passou à segunda posição. De 1985 em diante foi ultrapassada pelas neoplasias, ocupando ora a terceira, ora a quarta colocação entre as principais causas de morte. Foram a principal causa de óbitos entre as causas externas, no periodo estudado.

De acordo com dados do DATASUS (disponiveis em 30/06/2003 em http://tabnet.datasus.gov.br) ; a mortalidade por causas externas em vitimas residentes em Pouso Alegre, vem variando, no período de 1979 a 2000, entre 53,8 e 89.9 óbitos por cem mil habitantes. A taxa média de mortalidade média nos vinte e dois anos foi de 68,2 óbitos por cem mil habitantes com um desvio padrão de 10,0. Os óbitos se concentraram no sexo masculino e nas faixas etárias jovens (tabela 2). A tabela 4 mostra os óbitos do ano de 1998 por grupos de causas. Naquele ano, causas externas foram a quinta causa de mortes em Pouso Alegre, ocasionando $10,0 \%$ dos óbitos. 
Tabela 2 - População, total de óbitos. número de óbitos por causas externas e taxa de mortalidade por causas externas por cem mil habitantes na população residente em Pouso Alegre, MG, 1979-1994.

\begin{tabular}{|c|c|c|c|c|}
\hline Ano & $\begin{array}{c}\text { Total de } \\
\text { óbitos }\end{array}$ & População & $\begin{array}{l}\text { Óbitos por } \\
\text { causas } \\
\text { externas. }\end{array}$ & $\begin{array}{l}\text { Taxa de mortalidade } \mathrm{p} / \\
\text { causas extemas (por cem } \\
\text { mil habitantes) }\end{array}$ \\
\hline 1979 & 394 & 55.691 & 48 & 86,2 \\
\hline 1980 & 396 & 57.362 & 42 & 73,2 \\
\hline 1981 & 349 & 59.256 & 37 & 62,4 \\
\hline 1982 & 400 & 61.561 & 50 & 81,2 \\
\hline 1983 & 407 & 63.873 & 49 & 76,7 \\
\hline 1984 & 397 & 66.180 & 45 & 68,0 \\
\hline 1985 & 385 & 68.479 & 37 & 54,0 \\
\hline 1986 & 418 & 70.756 & 41 & 57,9 \\
\hline 1987 & 433 & 73.001 & 50 & 68.5 \\
\hline 1988 & 426 & 75.199 & 47 & 62,5 \\
\hline 1989 & 463 & 77.341 & 46 & 59.5 \\
\hline 1990 & 462 & 79.431 & 48 & 60,4 \\
\hline 1991 & 444 & 81.836 & 44 & 53,8 \\
\hline 1992 & 431 & 83.891 & 53 & 63,2 \\
\hline 1993 & 512 & 85.096 & 59 & 69.3 \\
\hline 1994 & 545 & 86.055 & 68 & 79,0 \\
\hline 1995 & 550 & 86.990 & 68 & 78,2 \\
\hline 1996 & 617 & 93.166 & 61 & 65,5 \\
\hline 1997 & 605 & 95.717 & 86 & 89,9 \\
\hline 1998 & 659 & 97.864 & 66 & 67,4 \\
\hline 1999 & 636 & 100.028 & 64 & 64,0 \\
\hline 2000 & 642 & 106.766 & 64 & 59,9 \\
\hline
\end{tabular}


Tabela 3 - Rede de estabelecimentos de saúde e internações hospitalares de Pouso Alegre - MG, 1999-2000.

\begin{tabular}{lr}
\hline Estabelecimento & número \\
\hline Hospitais & 3 \\
Hospitais SUS & 1 \\
Leitos hospitalares SUS & 236 \\
Unidades ambulatoriais & 54 \\
Postos de saúde rurais & 9 \\
Centros de saúde urbanos & 16 \\
Internações hospitalares -2000 & 9.378 \\
\hline
\end{tabular}

Tabela 4 - Número e proporção de óbitos por grupo de causas no municipio de Pouso Alegre, 1998.

\begin{tabular}{lrr}
\hline Causas de óbito & $\begin{array}{r}\text { n. } \\
\end{array}$ & $\begin{array}{r}\text { Mortalidade } \\
\text { proporcional } \\
\%\end{array}$ \\
\hline Doenças infecciosas e parasitárias & 25 & 3.8 \\
Neoplasias & 100 & 15,1 \\
Doenças do sangue, órgãos hematológicos, transtomos imunitários & 1 & 0,2 \\
Doenças endócrinas, nutricionais e metabólicas & 25 & 3,8 \\
Transtornos mentais e comportamentais & 8 & 1,2 \\
Doenças do sistema nervoso & 15 & 2,3 \\
Doenças do aparelho circulatório & 200 & 30.4 \\
Doenças do aparelho respiratório & 80 & 12,1 \\
Doenças do aparelho digestivo & 28 & 4,3 \\
Doenças da pele e tecido subcutâneo & 2 & 0.3 \\
Doenças do sistema osteomuscular e tecido conjuntivo & 2 & 0.3 \\
Doenças do aparelho geniturinário & 8 & 1,2 \\
Gravidez, parto e puerpério & 5 & 0,8 \\
Doenças originadas no periodo perinatal & 20 & 3.0 \\
Malformações congênitas, deformidades e anomalias cromossômicas & 6 & 0.9 \\
Sintomas. sinais e achados anormais em exames clinicos e laboratoriais & 68 & 10,3 \\
Causas externas & 66 & 10,0 \\
\hline TOTAL DE ÓBITOS & 659 & 100.0 \\
\hline
\end{tabular}


ANEXO 4 


\section{FICHA DE NOTIFICAÇÃO DE CAUSAS EXTERNAS Manual de Instruções para Preenchimento}

\section{I- Introdução -}

Este trabalho tem o objetivo de contribuir para a construção do conhecimento a respeito da causas externas. Trata-se de um tema pouco estudado apesar de sua óbvia importância para a Saúde Pública de nosso país. Ele se INCLUI ENTRE AS PRINCIPAIS CAUSAS DE ÓBITO DA POPULAÇÃO JOVEM DO NOSSO PAÍS E DO MUNDO. Além das mortes ocasiona também terriveis problemas em relação a INCAPACIDADES TEMPORÁRIAS E PERMANENTES, LESÕES DE NATUREZA E GRAVIDADE VARIÁVEL E AINDA INÚMERAS SEQÜELAS TANTO FÍSICAS COMO PSICOLÓGICAS para toda a população atingida.

Pela sua inegável prioridade urge então que sejam feitos estudos de maneira sistemática, e que todos os envolvidos neles estejam cientes da necessidade de trabalho sério e meticuloso, para que se possa obter resultados dignos de crédito e que apresentem utilidade social.

Para análise e organização dos dados do presente trabalho será utilizado o software Epi Info 6.02 da Organização Mundial de Saúde.

\section{II- Objetivos}

O objetivo deste Manual é o de instruir a equipe envolvida na coleta de dados para o trabalho e como proceder na coleta de dados no serviço. Ele também serve para normatizar as atividades dos entrevistadores.

O trabalho de campo é extremamente complexo e dificil, necessitando da persistência e da força de vontade de todos envolvidos. É fundamental lembrar sempre que o resultado final poderá ser muito importante, pois na medida em que se conheça mais a respeito dos graves agravos à saúde ocasionados pelas causas externas, se busque uma melhor atuação sobre seus fatores de risco, o que pode contribuir para a diminuição de sua morbidade e mortalidade, como já vem ocorrendo nos países desenvolvidos.

\section{III- Instruções Gerais:}

a) Ao abordar a pessoa que vai responder o questionário, de forma polida e educada lhe informe que estamos preenchendo uma ficha de notificação, que o tempo a ser dispendido com a mesma deverá ser menor que dez minutos, o que não the causará maiores transtornos nem atrapalhará seu atendimento. Deixe-a ciente que a finalidade do trabalho é científica sendo que sua privacidade será respeitada pois os resultados não serão identificados individualmente. $O$ entrevistado deve estar informado que todos os dados colhidos são sigilosos.

b) $\mathrm{O}$ entrevistador deve agir de forma a manter o entrevistado motivado a responder com boa vontade, para que as respostas sejam confiáveis. Não deve assumir atitudes que provoquem desinteresse ou hostilidade no respondente.

c) Preencha o questionário a lápis.

d) Se qualquer dúvida surgir durante a entrevista, anote-a ao lado da questão que a originou, separe o questionário assinalado, para discutir no máximo dentro de 24 horas com o coordenador. Não deixe de preencher as demais questões.

e) Limite suas perguntas ao enunciado do questionário evitando explicações sobre o que se deseja obter com as perguntas, pois estas explicações podem fazer com que o entrevistado seja influenciada pelo pesquisador. Se não houver como o entrevistado entender, repita toda a questão ou proponha um enunciado 
alternativo, desde que este não seja diferente daquilo que este manual propõe. As explicações ou reorganização de perguntas só deverão ocorrer em casos que forem absolutamente necessárias, devendo o entrevistador anotar quando este procedimento for feito, juntamente com a alternativa utilizada naquele momento, ao lado do enunciado da pergunta no questionário.

f) As perguntas apresentadas de forma fechada não devem ser reformuladas para que a padronização do trabalho não seja afetada. Esse procedimento vai evitar que haja atribuição de diferentes conteúdos para uma mesma pergunta.

g) As perguntas devem ser formuladas de maneira neutra. $O$ entrevistador nunca deve manifestar, nem através de palavras, de sua expressão ou pela inflexão de sua voz, atitudes de concordância, discordância ou surpresa com as respostas obtidas.

h) As respostas obtidas devem ser registradas precisamente como foram formuladas. Não são admissíveis interpretações ou análises das mesmas durante a coleta de dados.

i) As pessoas podem ser relutantes ao responder questões que se relacionam com comportamentos anti-sociais podendo ai surgir respostas pouco confiáveis. No caso deste trabalho as perguntas relacionadas a agressões podem levar a este tipo de problema. Para isto antes de iniciar o questionário informe ao entrevistado do sigilo da coleta de dados e da importância da resposta a todas as perguntas com sinceridade.

j) Devemos seguir religiosamente as instruções do manual e as da coordenação da pesquisa, pois temos de unificar as atitudes dos pesquisadores, falando todos a nesma linguagem, padronizando as condutas se quisermos obter um trabalho de credibilidade.

k) Não se muda a metodologia previamente planejada, antes do início do estudo, por outra após se iniciar a pesquisa. Isso, porque seria como querer modificar as regras de um jogo depois da partida entrar em andamento.

l) No caso de um dos entrevistados não se encontrar em condições de responder, entrevistar o acompanhante;

m) Se o entrevistado estiver recebendo algum tipo de intervenção aguardar seu término:

n) IMPORTANTE: Não devemos deixar de entrevistar nenhum dos participantes de nosso universo de pesquisa afim de que evitemos problemas de confiabilidade e significância de nosso trabalho.

o) Durante a realização da entrevista, verificaremos que muitos itens que dele constam não serão aplicados àquela situação específica. Estes tópicos devem ser deixados sem preencher. Nunca desconsidere a resposta NĀO SEI.

p) Se no momento da entrevista a situação no Pronto-Atendimento estiver tendo um pico de atendimentos, ou seja, aqueles momentos que a equipe passa pelo popularmente chamado "sufoco", com inúmeros atendimentos acontecendo ao mesmo tempo, quando ninguém está podendo preencher o formulário pois se isto for feito poderá acarretar prejuízo para o paciente , haja da seguinte maneira:

I - O atendimento do paciente é prioridade;

II- Já deixemos especificado como rotina de serviço que nestas situações, ou em quaisquer outras, a alta só é dada mediante o preenchimento da ficha e III - Se a situação do paciente for muito grave e ele não puder esperar para ser encaminhado para o Hospital ou para o Pronto-Socorro, quem acompanhar a transferência preencherá a ficha ou se não for possivel comunicar à coordenação do trabalho para que seja providenciado o preenchimento o mais breve possivel. 
IV- Instruções Específicas - PARA SEREM LIDAS TENDO O QUESTIONÁRIO EM MÃOS.

\section{1-Identificação}

a) O cabeçalho deve ser preenchido por extenso, pela recepção,na hora que o paciente chegar, anotando-se as informações Hora de início da coleta Nome, Endereço, Telefone, Bairro, CEP, Cidade. Não omitir nenhum dado

b) Idade preencher o número de anos completos. Menor de um ano anotar o número de meses ou de dias se menor de um mês.

c) Sexo e Estado Civil assinalar a opção. Profissão preencher conforme informado

d) No inicio do questionário existe o item $\mathbf{N} .^{\circ}$ do cartão SUS não deve ser preenchido pois o cartão SUS não foi implantado. . Esse espaço

e) Data e hora de entrada: colocar dia e hora que o paciente entrou no serviço.

\section{2- CAUSA}

a) Nesta questão assinalar com um $\mathbf{X i s}(\mathbf{X})$ a resposta dada pelo entrevistado.

b) Observar que Queda em Acidentes de trânsito se referem a quedas de moto, bicicleta. Já Queda em Outras lesões acidentais é para as quedas acidentais sem envolvimento de veiculos.

c) Outras lesões acidentais, Lesões autoprovocadas e Agressões têm também itens parecidos: afogamento, envenenamento, arma de fogo, objeto cortante, objeto contundente, força corporal. Observar com atenção o local que se deve assinalar

d) Atentar para a possibilidade de serem respondidas palavras sinônimas, como por exemplo, chamar-se Colisão de Trombada, o que é a mesma coisa. Nesses casos substituir a resposta por sua correspondente adequada.

e) Utilizar as definições da CID-10 já distribuídas no caso de dúvidas.

f) A descrição do evento deve ser sucinta porém bem detalhada

g) No item código não deverá haver preenchimento.

\section{3- AVAliAÇÃO DA GRAVIDADE DAS LESÕES - $\underline{\text { SUSPENSO }} \underline{O}$} PREENCHIMENTO DESTA PARTE!!!!

a) A primeira parte deverá ser preenchida de acordo com as impressões do entrevistador.

b) Escala de coma de GLASGOW:

Descrita em 1974 por Teasdale e Jannet [53], a Escala de Coma de Glasgow é utilizada para avaliar o nível de consciência dos pacientes. É empregada não só nos casos de traumatismo crânio-encefálico, podendo estar alterada em outras situaçōes. como choque hipovolêmico [35]. Calcula-se o escore através da soma de valores de très tipos de resposta: abertura ocular, resposta ao comando verbal e a dor ( Tabela 1 ). $O$ valor mínimo é 3 e o máximo 15, sendo que quanto maior o valor, menor será o nível de gravidade e melhor será o prognóstico. A Escala de Coma de Glasgow é muito utilizada, inclusive nos conceitos do Suporte Avançado de Vida no Traumatizado ( Advanced Trauma Life Support ou ATLS ) para a orientação de algumas normas e condutas [21]. Um paciente em coma, por definição, não apresenta abertura ocular ( abertura ocular $=1$ ), não tem capacidade para obedecer comando ( resposta motora $=1$ a 5 ), e não verbaliza ( resposta verbal $=1$ a 2 ). Deste modo, pacientes com escore menor que oito, e a maioria daqueles com escore igual a oito, estão em coma. Pacientes com Escala de Coma de Glasgow maior que oito não estão em coma. 
Tabela 1 - Escala de Coma de Glasgow

AVALIAÇÁO NEUROLÓGICA

TIPO DE RESPOSTA

\section{VALOR}

Abertura ocular

espontânea

ao comando verbal

a estímulo doloroso

sem resposta

4
3
2
1

Melhor resposta verbal

orientado

confuso

palavras inapropriadas

sons incompreensiveis

sem resposta

\section{5}

4

3

Melhor resposta motora

obedece aos comandos

localiza a dor -movimenta

flexão normal - retira

flexão anormal

extensão anormal

sem resposta

- ao comando verbal

- ao estímulo doloroso

4- Os itens de III a VIII- são auto-explicativos e dever-se-á assinalar com um $\mathbf{X}$ a resposta dada. Se não se encontrar a resposta entre os listados preencher Qual?

5- Questão IV- Quando? Dia, Hora, Local- preencher os espaços com as informações do paciente ou do acompanhante.

\section{6-Questão VII- Tempo de permanência}

Calcular levando em conta a hora de entrada e a hora de saida do paciente do serviço, ou sua transferência.

\section{7-Após verificação dos tipos de lesão preencher o quadro da página 2 ou as perguntas seguintes}

Assinalar com um $\mathbf{X}$ a resposta dada. Se a resposta a esta questão foi Não ou Não sei passe para a questão n. $^{\circ} X I X$ se foi Sim vá para a questão n. ${ }^{\circ} X V I I$.

\section{8- Localização}

a- Esta questão para ser formulada necessita que o entrevistador entenda o que seja lesão. Pode ser explicado que lesão é o dano físico causado pelo evento ou seja é a conseqüência do evento para o corpo.

b- Para que possamos assinalar a topografia exata deve-se observar o paciente atentamente em todos os seus segmentos corporais

c- Quaisquer lesões que ocorram envolvendo orgãos situados no interior das cavidades craniana, cabeça, pescoço, cavidade torácica, abdominal e/ou pélvica serão computadas no item 7- Traumatismos de órgãos internos. Qualquer dúvida recorrer aos desenhos do final deste Manual.

\section{9- Questão XVIII- Como foi a lesão que ocorreu? Qual o tipo da lesão?}


Esta é uma questão que o pesquisador deve estar atento para que não ocorra erro em relação ao preenchimento correto do questionário.

Este estudo padroniza os tipos de lesão de acordo com a última edição $\left(10 .^{a}\right)$ da Classificação Internacional das Doenças (CID-10) que é :

- Traumatismo superficial: Inclui abrasão, bolha, contusão(inclusive equimose e hematoma), lesão, traumatismo por corpo estranho superficial sem ferimentos.

- Ferimento incluindo: Corte, ferimento perfurante, SOE, com corpo estranho penetrante, laceração.

- Fratura incluindo: Fratura aberta ou fratura fechada.

- Luxação, Entorse e Distensão incluindo: Avulsão, distensão, entorse, hemartrose traumática, laceração, luxação, ruptura traumática, subluxação traumática; estes sempre em relação a articulação (cápsula) e ligamento.

- Traumatismos dos nervos e da medula espinhal incluindo: Divisão traumática do nervo. hematomielia traumática, lesão completa ou incompleta da medula espinhal, lesão em continuidade em nervos e na medula espinhal, paralisia (transitória) traumática, paraplegia traumática, quadriplegia, secção traumática do nervo.

Traumatismo dos vasos sangüineos incluindo: Aneurisma ou fistula (arteriovenoso) traumáticos, avulsão, hematoma arterial traumático, laceração, lesão, ruptura traumática, secção.

- Traumatismo dos tendões e dos músculos incluindo: Avulsão, laceração, lesão, ruptura traumática, secção.

- Lesões por esmagamento incluindo amputações traumáticas.

- Traumatismo de orgãos internos incluindo: Contusão. esmagamento, ferimentos por explosão, ferimentos perfurantes traumáticos, hematoma traumático, laceração traumática, lesões por concussão, rompimento traumático e ruptura traumática.

- Outros traumatismos e os não especificados.

Para trabalharmos nesta questão é necessário que se tenha a padronização de cada tipo de lesão a ser estudada, pois o comportamento dos entrevistadores deve ser uniforme, sem que cada um siga critérios próprios de classificação do que for referido pelos entrevistados. Foi utilizado o Stedman Dicionário Médico 25." edição de 1996, editora Guanabara-Koogan, escrito originalmente por Thomas Lathrop Stedman, para se chegar a esta padronização.

Serão utilizadas as seguintes definições:

Tipos e definiçōes padronizadas das lesões definidas pela CID-10 e Dicionário Médico Stedman

\begin{tabular}{|l|l|}
\hline TIPO & DEFINIÇÃO \\
\hline Abrasão & $\begin{array}{l}\text { Ferida escoriada; uma escoriação ou remoção } \\
\text { circunscrita das camadas superficiais da pele, ou } \\
\text { mucosa. 2-Raspagem de parte da superficie. }\end{array}$ \\
\hline Aneurisma traumático & $\begin{array}{l}\text { Dilatação circunscrita de uma artéria ou um tumor que } \\
\text { contém sangue que se une diretamente com a luz da } \\
\text { artéria; resultante de lesão fisica da parede da artéria, } \\
\text { geralmente a falso (Comunica c/ vaso roto) ou artério- } \\
\text { venoso. }\end{array}$ \\
\hline Avulsåo & Rasgão ou separação forçada. \\
\hline
\end{tabular}




\begin{tabular}{|c|c|}
\hline Bolha & $\begin{array}{l}\text { Grande vesícula que aparece como área circunscrita da } \\
\text { epiderme da estrutura subepidérmica (b. subepidérmica) } \\
\text { ou área circunscrita de separação de células epidérmicas } \\
\text { (b. intraepidérmica) produzida pela presença de soro, às } \\
\text { vezes misturado com sangue e ocasionalmente causada } \\
\text { por uma substância injetada por via intra ou } \\
\text { subepidérmica. }\end{array}$ \\
\hline Contusão & $\begin{array}{l}\text { Qualquer lesão (em geral produzida por um golpe) em } \\
\text { que a pele não é rompida. }\end{array}$ \\
\hline Corte (incisão) & $\begin{array}{l}\text { Um ferimento limpo como o feito por um instrumento } \\
\text { cirúrgico. }\end{array}$ \\
\hline Distensão & Ato de ser distendido ou esticado. \\
\hline Divisão traumática de um nervo & Secção traumática. \\
\hline Entorse & $\begin{array}{l}\text { Lesão de um ligamento quando uma articulação é } \\
\text { movimentada em amplitude maior que a normal, porém } \\
\text { sem luxação ou fratura. }\end{array}$ \\
\hline Equimose & $\begin{array}{l}\text { Uma placa púrpura causada por extravasamento de } \\
\text { sangue, diferindo de petéquias somente pelo tamanho. }\end{array}$ \\
\hline Esmagamento & $\begin{array}{l}\text { Contusão decorrente da pressão entre dois corpos } \\
\text { sólidos. }\end{array}$ \\
\hline Ferimento & $\begin{array}{l}\text { Traumatismo de qualquer lugar dos tecidos do corpo, } \\
\text { principalmente aquele causado por meios fisicos e com } \\
\text { interrupção de continuidade. }\end{array}$ \\
\hline Ferimento penetrante & $\begin{array}{l}\text { Ruptura da superficie do corpo que se estende para o } \\
\text { tecido subjacente ou para o interior de uma cavidade } \\
\text { corporal. }\end{array}$ \\
\hline Ferimento perfurante & Ferimento com orificio de entrada e de saída. \\
\hline Fístula artério-venosa & $\begin{array}{l}\text { Comunicação anormal eriīe uma artériá e uma veia em } \\
\text { geral resuitante da formação de um aneurisma artério- } \\
\text { venoso }\end{array}$ \\
\hline Fratura Aberta & $\begin{array}{l}\text { Aquela em que a pele está perfurada e existe uma ferida } \\
\text { por baixo da fratura. }\end{array}$ \\
\hline Fratura Fechada & Aquela cuja pele está íntegra no local da fratura \\
\hline Hemartrose & Presença de sangue em uma articulação. \\
\hline Hematoma & $\begin{array}{l}\text { Massa localizada de sangue extravasado, relativa ou } \\
\text { completamente localizada dentro de um órgão ou tecido, } \\
\text { um espaço ou um espaço potencial; o sangue em geral } \\
\text { está coagulado, e, dependendo do tempo que aí esteve } \\
\text { pode manifestar vários graus de organização ou } \\
\text { descoloramento. }\end{array}$ \\
\hline Hematomielia & $\begin{array}{l}\text { Hemorragia dentro da substância da medula espinhal } \\
\text { por lesão pós-traumática. }\end{array}$ \\
\hline Laceração & $\begin{array}{l}\text { Uma ferida rota ou lacerada (que possui uma borda } \\
\text { rendada) ou uma ferida cortada acidentalmente. }\end{array}$ \\
\hline Lesão & Dano ou ferida decorrente de um traumatismo. \\
\hline $\begin{array}{l}\text { Luxação } \\
\text { (figura no Anexo 1) }\end{array}$ & $\begin{array}{l}\text { Distúrbio ou desarranjo da relação normal dos ossos que } \\
\text { entram na formação de uma articulação. }\end{array}$ \\
\hline Paralisia (transitória) traumática & $\begin{array}{l}\text { Perda de movimentos em caráter temporário devido a } \\
\text { traumatismo. }\end{array}$ \\
\hline Paraplegia & $\begin{array}{l}\text { Paralisia dos membros inferiores e em geral da porção } \\
\text { inferior do tronco. }\end{array}$ \\
\hline Petéquias & $\begin{array}{l}\text { Diminutos pontos hemorrágicos, desde o tamanho } \\
\text { puntiforme até o da cabeça de um alfinete na pele e que } \\
\text { não desaparecem pela diascopia. }\end{array}$ \\
\hline Ruptura traumática de uma articulação & Solução de continuidade ou laceração. \\
\hline Seç̧ão & $\begin{array}{l}\text { Corte ou divisão - Uma superficie de corte - Uma } \\
\text { fatia fina de tecidos, células ou qualquer material para }\end{array}$ \\
\hline
\end{tabular}




\begin{tabular}{|l|l|}
\hline & exame. \\
\hline $\begin{array}{l}\text { Subluxação } \\
\text { (figura no Anexo 1) }\end{array}$ & $\begin{array}{l}\text { Uma luxação incompleta; embora a relação esteja } \\
\text { alterada, o contato entre as superficies permanece. }\end{array}$ \\
\hline Tetraplegia & Paralisia dos quatro membros. \\
\hline Traumatismo & O mesmo que lesão. \\
\hline
\end{tabular}

10- Preenchimento do quadro VII - Número de lesões - O entrevistador deverá em cada segmento do corpo do paciente localizar o local do qudro que corresponde à localização da lesão e ao tipo. Deverá preencher este espaço colocando no local o número correspondente à quantidade de lesões daquele tipo situadas naquele local. Exemplo: Se um individuo teve quatro ferimentos na cabeça, deverá ser colocado na interseção da terceira linha do quadro com sua segunda coluna o número 4. Veja este exemplo na próxima página:

VII - LESÃO E LOCALIZAÇÃO (PREENCHER USANDO O NÚMERO DE LESÕES POR LOCALIZAÇÃO)

\begin{tabular}{|l|l|l|l|l|}
\hline & 1- Cabeça & 2- Pescoço & 3- Tórax & 4- Abdome \\
\hline 1- Traumatismo superficial & & & & \\
\hline 2- Ferimento & 4 & & & \\
\hline 3- Luxação. entorse. distensão & & & & \\
\hline 4- Traumatismos nervos e medula espinhal & & & & \\
\hline 5- Traumatismo vasos sangüineos & & & & \\
\hline 6- Traumatismo tendões e músculos & & & & \\
\hline 7- Traumatismos órgãos internos & & & & \\
\hline 8- Lesões por esmagamento & & & & \\
\hline 9- Corpo estranho & & & & \\
\hline 10- Queimaduras & & & & \\
\hline
\end{tabular}

11- No item FRATURA assinalar a opção desejada. Já o item INTOXICAÇÃO deverá ter sua causa preenchida por extenso.

12- Descrição das lesões - Finalmente descrever as lesões encontradas de forma sucinta porém completa.

\section{3- Encerrando o preenchimento}

Após o término do preenchimento o entrevistador deve anotar o seu nome no local indicado e assinar o questionário. Logo depois deve agradecer ao entrevistado pela colaboração. As entrevistas devem ser encaminhadas dentro de um prazo de 24 horas à revisão pesquisa que fará a revisão, verificará a presença de eventuais erros e fará o controle de qualidade e encaminhará para a SMS. 


\section{TOPOGRAFIA DAS LESÕES}

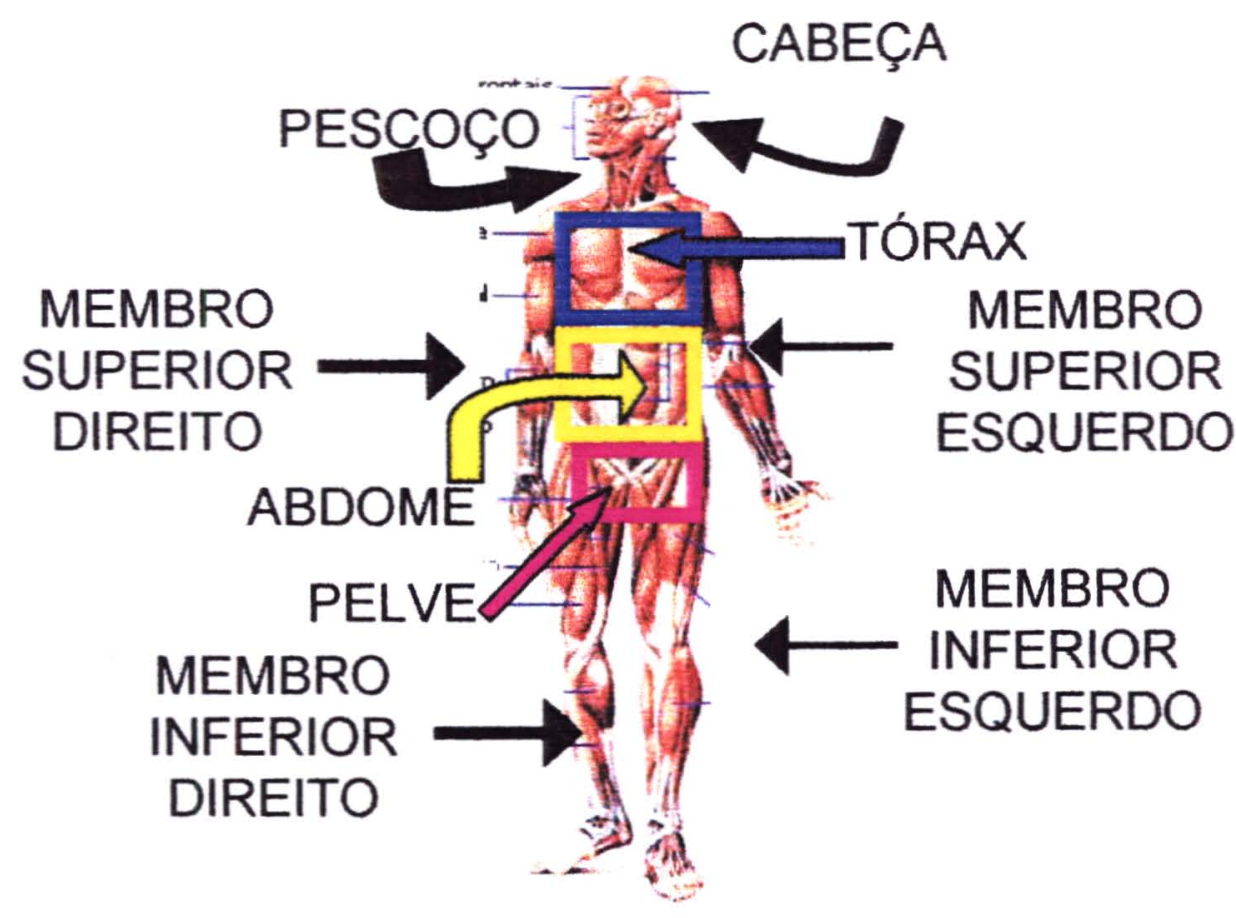

CABEÇA

1

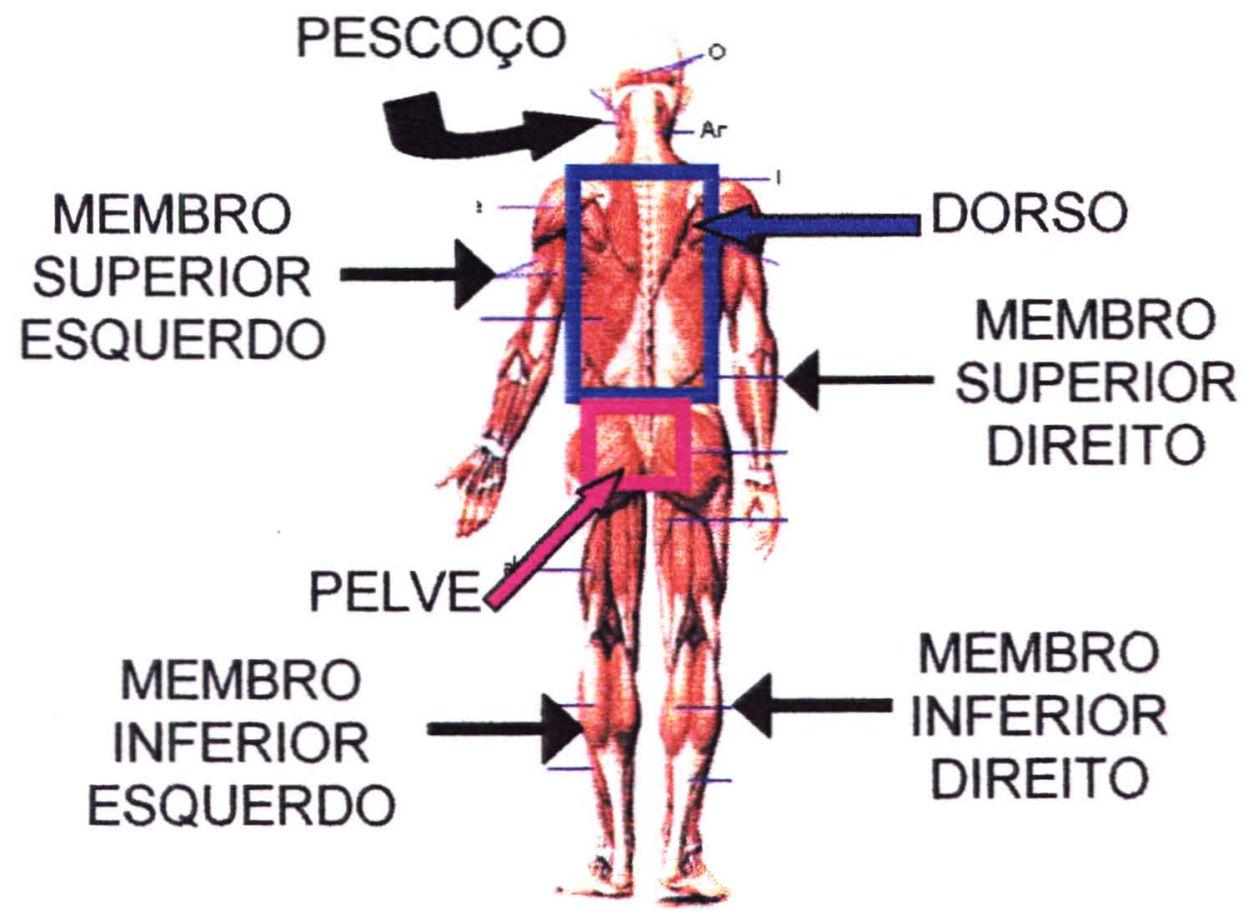




\section{TOPOGRAFIA DAS FRATURAS}

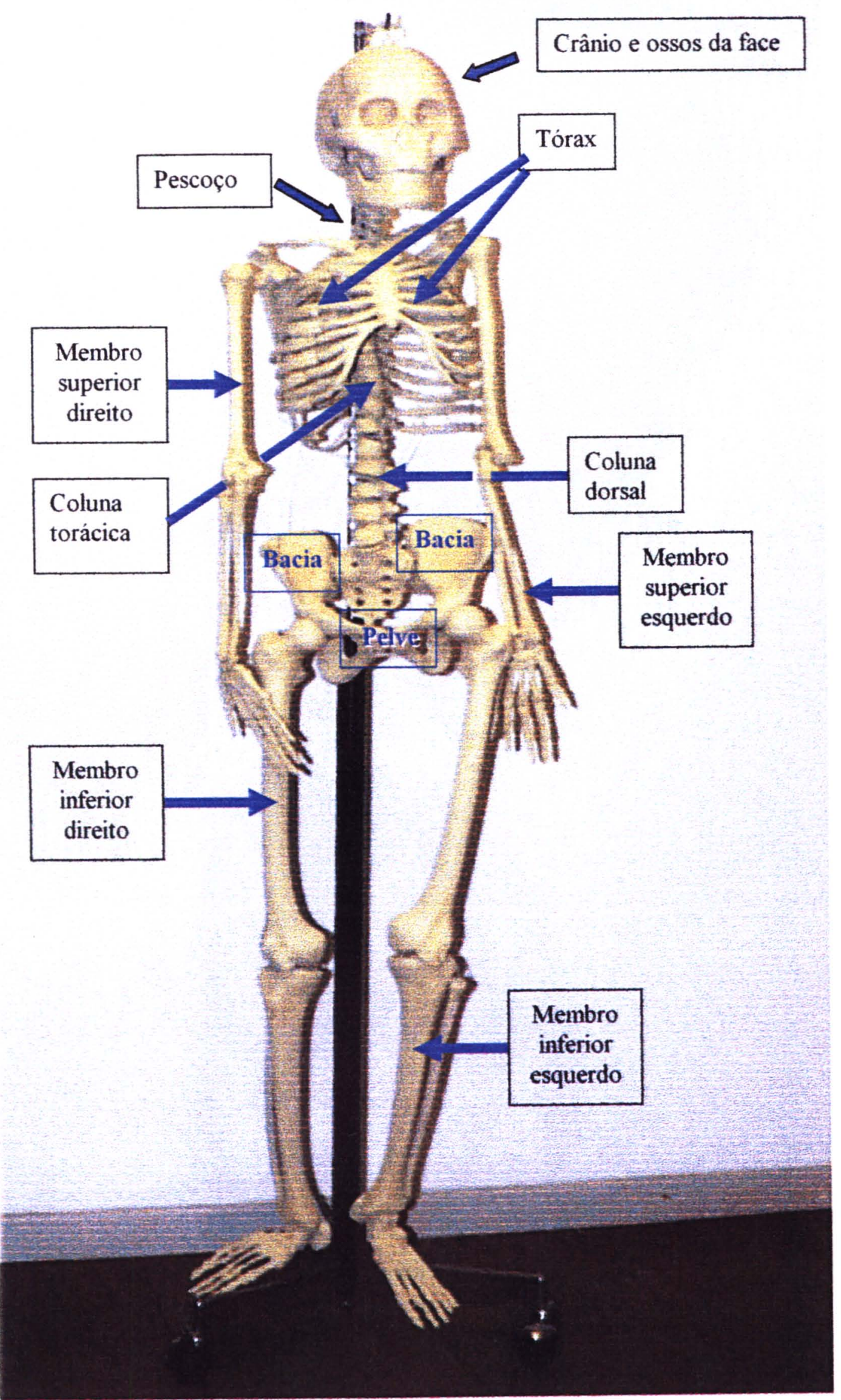

